Wanessa Cartaxo Soares

\title{
ANÁLISE DE RECALQUES DE EDIFÍCIOS EM SOLOS MELHORADOS COM ESTACAS DE COMPACTAÇÃO
}

\begin{abstract}
Dissertação apresentada à Escola de Engenharia de São Carlos da Universidade de São Paulo, como parte dos requisitos para obtenção do título de Mestre em Geotecnia.
\end{abstract}

Orientador: Prof.Dr. José Carlos A. Cintra

São Carlos, Setembro de 2005 


\section{FOLHA DE JULGAMENTO}

Candidata: Engenheira WANESSA CARTAXO SOARES

Dissertação defendida e julgada em 26-10-2005 perante a Comissão Julgadora:

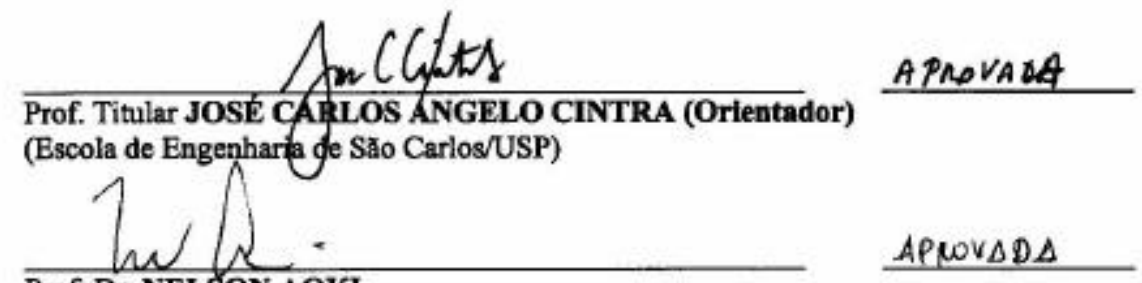

Prof. Dr. NELSON AOKI

(Escola de Engenharia de São Carlos/USP)

tdemantara hoo

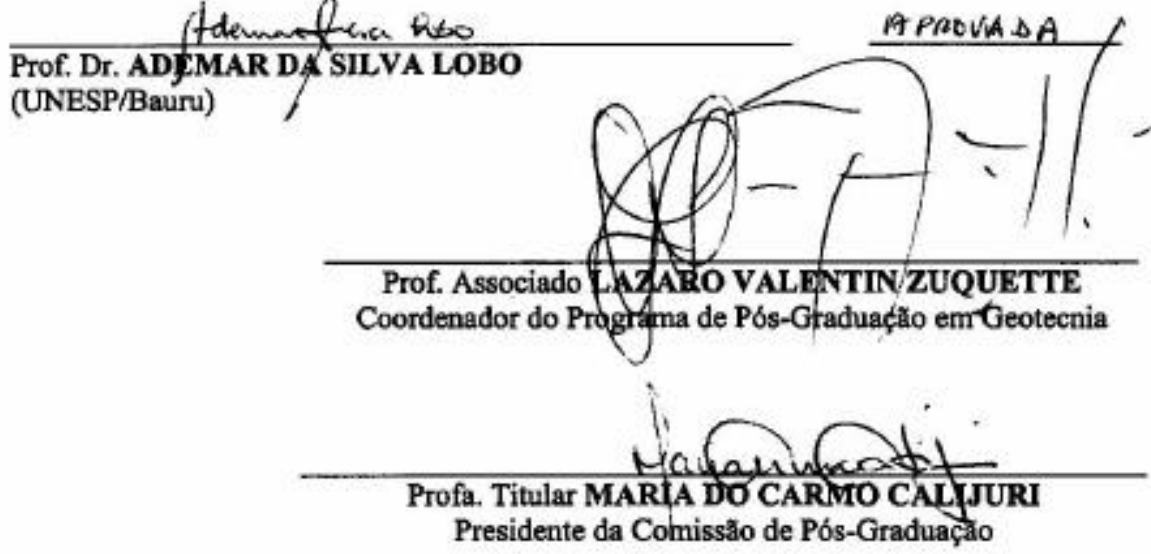


Aos meus pais e meus irmãos 


\section{AGRADECIMENTOS}

Ao Prof. Dr. José Carlos Angelo Cintra pela importante orientação durante o desenvolvimento deste trabalho.

Ao Prof. Dr. Nelson Aoki pelas valiosas sugestões ao longo da pesquisa.

Aos professores, funcionários e colegas do Departamento de Geotecnia da USP/São Carlos, em particular, a Jeselay Hemetério dos Reis, e, especialmente a Thiago, pelo apoio e compreensão.

Aos funcionários da Concresolo \& Copesolo pela ajuda e amizade.

A CAPES pela bolsa concedida.

A meu pai, pelos ensinamentos, lições e apoio constante durante a minha caminhada, e a minha mãe, pela acolhida sempre presente em todos os momentos, principalmente nos mais difíceis.

A meus irmãos, Wilson e Waldez, pela companhia e ajuda mútua em nosso ainda contínuo aprendizado, e ao pequeno Gabriel, que nos enche de esperança, alegria e renovação. 
RESUMO

SOARES, W.C. (2005) "Análise de recalques de edifícios em solos melhorados com estacas de compactação”. São Carlos, 2005. 131 p. Dissertação de mestrado. Escola de Engenharia de São Carlos. Universidade de São Paulo.

As estacas de compactação são freqüentemente utilizadas como método de melhoria de solos arenosos em algumas cidades do litoral nordestino, principalmente João Pessoa e Recife. Introduzem-se materiais como areia, cimento e/ou brita pelo procedimento de vibrodeslocamento. Também conhecidas como estacas de areia ou granulares, o seu emprego provoca o aumento da capacidade de carga e a redução de recalques, viabilizando a execução de sapatas em locais que não permitiriam esse tipo de fundação. A majoração da capacidade de carga já foi comprovada em pesquisa anterior por meio de prova de carga em placa. Nesta pesquisa, é analisada a eficácia do processo de melhoria do solo na redução dos recalques, pelo monitoramento de cinco edifícios sobre solo melhorado com estacas de compactação na cidade de João Pessoa. São comparados os resultados obtidos por meio do monitoramento com recalques estimados para a situação hipotética dos edifícios em solo natural, sem compactação. É feita uma avaliação ao longo do tempo de monitoramento da evolução dos recalques medidos.

Palavras-chave: estacas de compactação, monitoramento de recalques, método Aoki-Lopes. 


\section{ABSTRACT}

SOARES, W.C. (2005) "Settlement analysis of buildings founded on improved soil by compaction piles". São Carlos, 2005. 131 p. Dissertação de mestrado. Escola de Engenharia de São Carlos. Universidade de São Paulo.

Compaction piles are often used as a sandy soil improvement process in some cities of brazilian Northeast region, specially João Pessoa and Recife. Also known as granular or sand piles, this practice promotes an increase on bearing capacity and settlement reduction, allowing footing use in places that would not permit this type of foundation. Its effectiveness on bearing capacity increase was proved through plate load test in previous work. It is presented here an analysis of settlement reduction provided by the method. Five buildings on improved soil by compaction piles had their settlements measured in the city of João Pessoa. The results obtained through the measurement are compared to estimated settlements for hypothetical cases of the buildings founded on natural soil, without compaction. An evaluation along observation time of the measured settlements is made.

Key words: compaction piles, settlement measurement, Aoki-Lopes procedure. 


\section{SUMÁRIO}

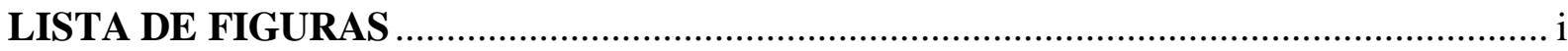

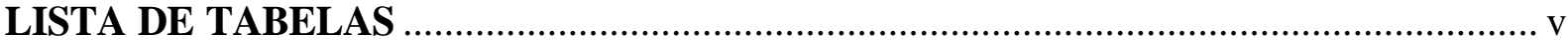

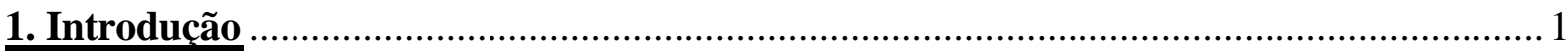

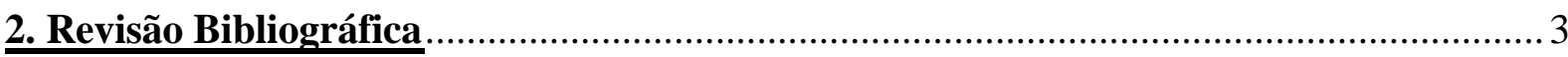

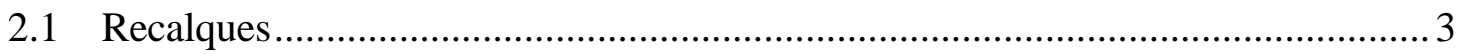

2.1.1 Metodologias de Cálculo ..................................................................... 6

2.1.2 Parâmetros de deformabilidade .............................................................. 10

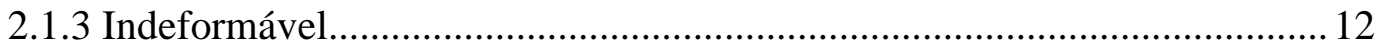

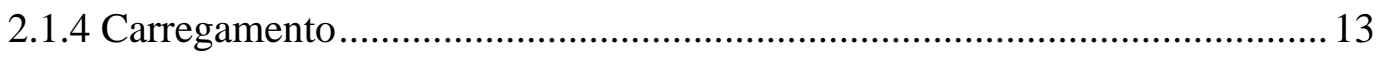

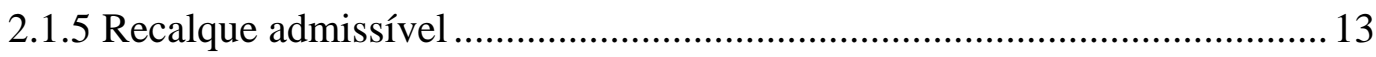

2.1.7 Extrapolação de curvas tempo x recalque .............................................. 16

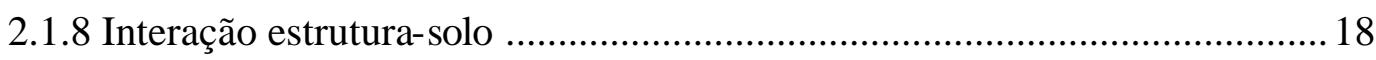

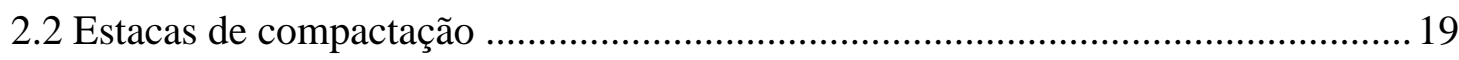

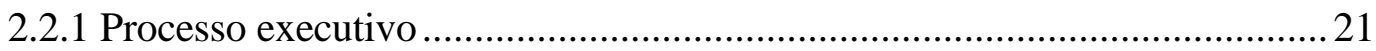

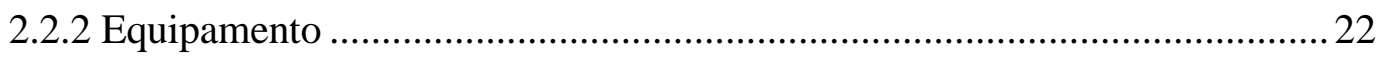

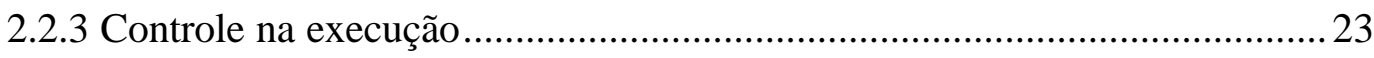

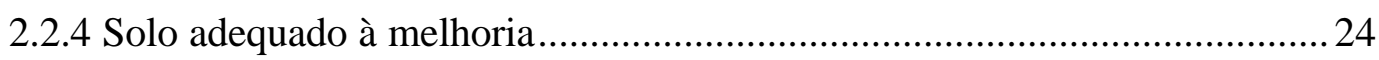

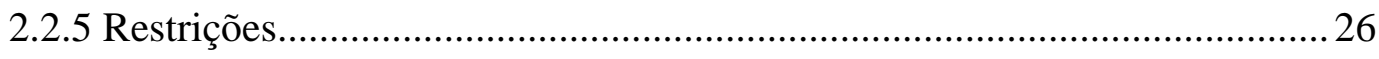

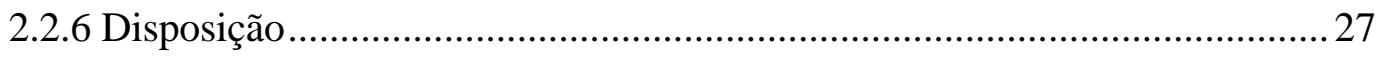

2.2.7 Resultados e análises de ensaios de avaliação ......................................... 27

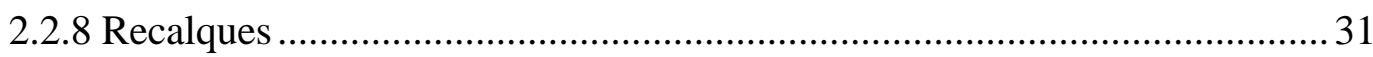




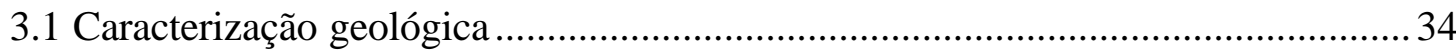

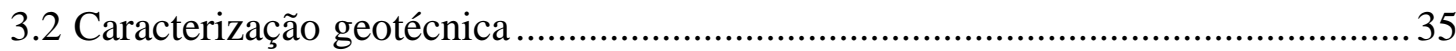

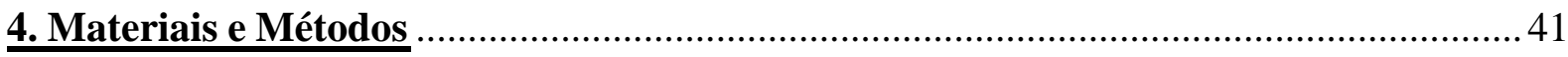

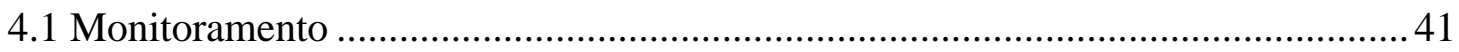

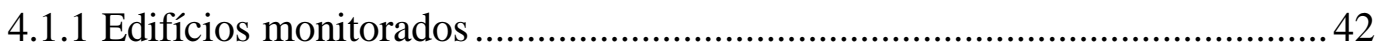

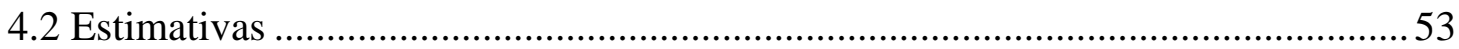

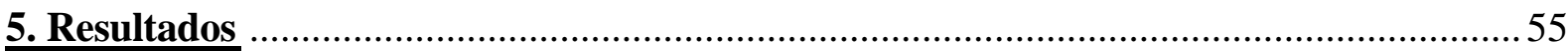

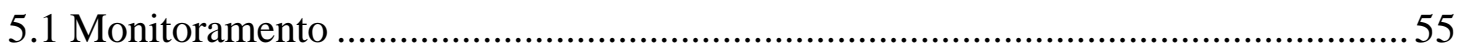

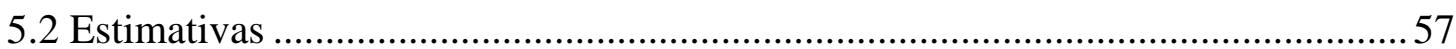

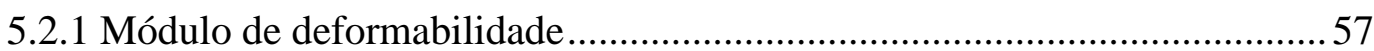

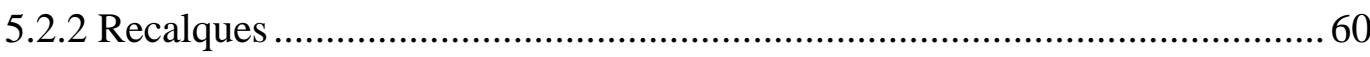

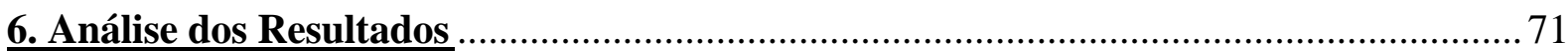

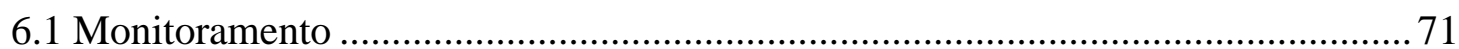

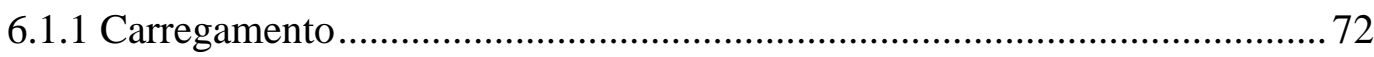

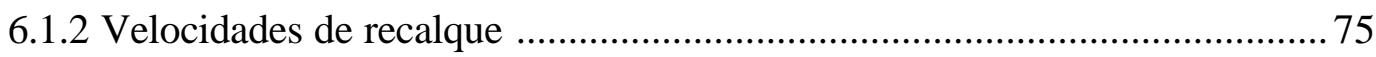

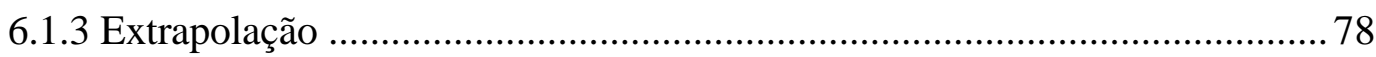

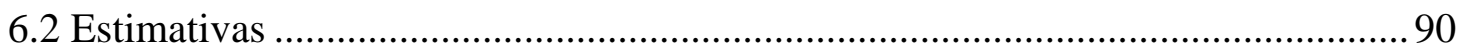

6.2.1 Módulo de Deformabilidade .................................................................. 90

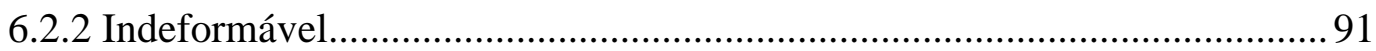

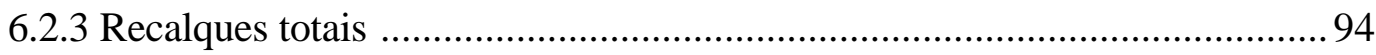

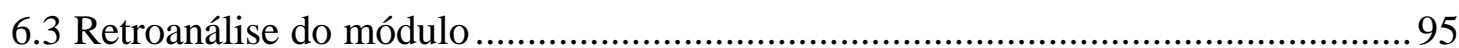


7. Conclusão 103 REFERÊNCIAS BIBLIOGRÁFICAS 106 ANEXO A 112 APÊNDICE A 114 


\section{LISTA DE FIGURAS}

Figura 2.1 - Recalques de uma fundação superficial sob carga vertical centrada 5

Figura 2.2 - Fator de influência na deformação vertical (Schmertmann, 1970 apud Cintra et al., 2003).

Figura 2.3 - Fator de influência na deformação vertical (Schmertmann, 1978 apud Cintra et al., 2003).

Figura 2.4 - Processo executivo de estaca de compactação por vibro-deslocamento (Bell, 1993).

Figura 2.5 - Bate-estacas usado na execução de estacas de areia (Soares \& Soares, 2004)..... 23

Figura 2.6 - Estacas de compactação prontas (Copesolo, 2005) 23

Figura 2.7 - Faixa de ocorrência em que a técnica é mais eficiente (adaptado de GUSMÃO FILHO, 1998 apud SOARES,2002 ).

Figura 2.8 - Boletim de sondagem com os valores do índice de resistência à penetração $\mathrm{N}_{\mathrm{SPT}}$ médios, obtidos em solo natural e em malhas e estacas com espaçamento de 80, 90 e $100 \mathrm{~cm}$. (SOARES, 2002).

Figura 2.9 - Ensaio de cone em solo natural (SOARES, 2002). 29

Figura 2.10 - Ensaio de cone em malha de estacas com espaçamento de $90 \mathrm{~cm}$ (SOARES, 2002).

Figura 2.11 - Provas de carga realizadas em terreno natural e compactado (SOARES, 2002).

Figura 2.12 - Ábaco para cálculo do módulo equivalente para $\mathrm{E}_{\text {estaca }}=500 \mathrm{MPa}$ (Alves et al . ,2000).

Figura 3.1 - Perfil Geológico da cidade de João Pessoa (Gusmão Filho, 1982). 35

Figura 3.2 - Residencial Maison des Princes: perfil médio representativo das sondagens SPT realizadas em solo natural $\left(\mathrm{N}_{\mathrm{SPT}} \mathrm{S}\right.$ em linha azul) e em solo compactado $\left(\mathrm{N}_{\mathrm{SPT}} \mathrm{s}\right.$ linha vermelha)

Figura 3.3 - Residencial Vale Verzasca: perfil médio representativo das sondagens SPT realizadas em solo natural $\left(\mathrm{N}_{\mathrm{SPT}} \mathrm{S}\right.$ em linha azul) e em solo compactado $\left(\mathrm{N}_{\mathrm{SPT}} \mathrm{S}\right.$ linha vermelha).

Figura 3.4 - Residencial Maison Elizabeth: perfil médio representativo das sondagens SPT realizadas em solo natural $\left(\mathrm{N}_{\mathrm{SPT}} \mathrm{S}\right.$ em linha azul) e em solo compactado $\left(\mathrm{N}_{\mathrm{SPT}} \mathrm{S}\right.$ linha vermelha).

Figura 3.5 - Residencial Boulevard Manaíra: perfil médio representativo das sondagens SPT realizadas em solo natural $\left(\mathrm{N}_{\mathrm{SPT}} \mathrm{S}\right.$ em linha azul) e em solo compactado $\left(\mathrm{N}_{\mathrm{SPT}} \mathrm{S}\right.$ linha vermelha)..... 
Figura 3.6 - Edifício Stéphano: perfil médio representativo das sondagens SPT realizadas em solo natural $\left(\mathrm{N}_{\mathrm{SPT}} \mathrm{S}\right.$ em linha azul) e em solo compactado $\left(\mathrm{N}_{\mathrm{SPT}} \mathrm{s}\right.$ linha vermelha) .................40

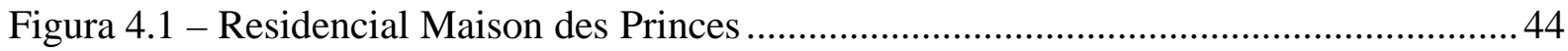

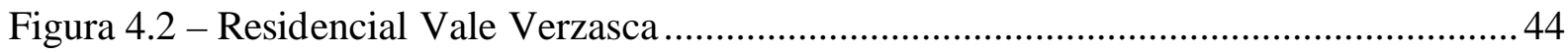

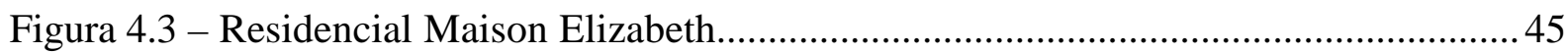

Figura 4.4 - Edifício Boulevard manaíra ........................................................................ 45

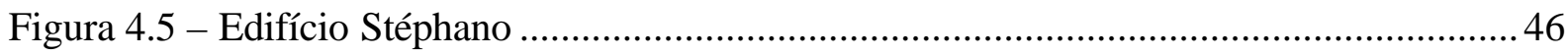

Figura 4.6 - Maison des Princes: planta de forma das sapatas e esquema de locação das

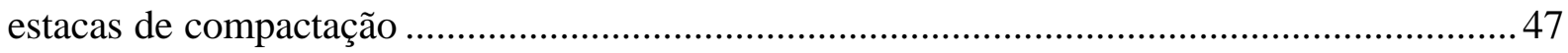

Figura 4.7 - Vale Verzasca: planta de forma das sapatas e esquema de locação das estacas de

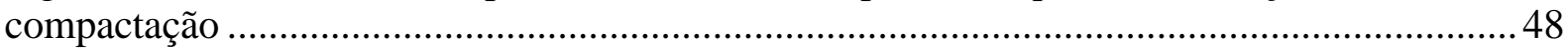

Figura 4.8 - Maison Elizabeth: planta de forma das sapatas e esquema de locação das estacas de compactação

Figura 4.9 - Boulevard Manaíra: planta de forma das sapatas e esquema de locação das estacas de compactação 50

Figura 4.10 - Stéphano: planta de forma das sapatas e esquema de locação das estacas de compactação 51

Figura 5.1 - Maison des Princes: curvas tempo x recalque de três sapatas ............................ 55

Figura 5.2 - Vale Verzasca: curvas tempo x recalque de três sapatas ...................................56

Figura 5.3 - Maison Elizabeth: curvas tempo x recalque de três sapatas ............................... 56

Figura 5.4 - Boulevard Manaíra: curvas tempo x recalque de três sapatas ............................57

Figura 5.5 - Stéphano: curvas tempo x recalque de três sapatas......................................... 57

Figura 5.6 - Maison des Princes: Gráfico de $\mathrm{E}_{0}$ x z para solo natural e compactado ...............58

Figura 5.7 - Vale Verzasca: Gráfico de $\mathrm{E}_{0}$ x z para solo natural e compactado ......................58

Figura 5.8 - Maison Elizabeth: Gráfico de $\mathrm{E}_{0}$ x z para solo natural e compactado ................. 59

Figura 5.9 - Boulevard Manaíra: Gráfico de $\mathrm{E}_{0}$ x z para solo natural e compactado ...............59

Figura 5.10 - Stéphano: Gráfico de $\mathrm{E}_{0} \mathrm{x} \mathrm{z}$ para solo natural e compactado .............................. 60

Figura 5.11 - Maison des Princes: curvas de isorecalques totais para solo natural $(\mathrm{mm})$....... 61

Figura 5.12 - Maison des Princes: curvas de isorecalques totais para solo compactado (mm) 61

Figura 5.13 - Maison des Princes: superfície de isorecalques totais para solo compactado.... 62 
Figura 5.14 - Vale Verzasca: curvas de isorecalques totais para solo natural (mm) 63

Figura 5.15 - Vale Verzasca: curvas de isorecalques totais para solo compactado (mm) ....... 63

Figura 5.16 - Vale Verzasca: superfície de isorecalques totais para solo compactado ........... 64

Figura 5.17 - Maison Elizabeth: curvas de isorecalques totais para solo natural (mm) ..........65

Figura 5.18- Maison Elizabeth: curvas de isorecalques totais para solo compactado (mm) ...65

Figura 5.19 - Maison Elizabeth: superfície de isorecalques totais para solo compactado....... 66

Figura 5.20 - Boulevard Manaíra: curvas de isorecalques totais para solo natural (mm) .......67

Figura 5.21 - Boulevard Manaíra: curvas de isorecalques totais para solo compactado (mm)67

Figura 5.22 -Boulevard Manaíra: superfície de isorecalques totais para solo compactado..... 68

Figura 5.23 - Stéphano: curvas de isorecalques totais para solo natural (mm) ..................... 69

Figura 5.24 - Stéphano: curvas de isorecalques totais para solo compactado $(\mathrm{mm})$.............. 69

Figura 5.25 - Stéphano: superfície de isorecalques totais para solo compactado ................... 70

Figura 6.1 - Maison des Princes: gráfico tempo x recalque x carregamento de três sapatas... 72

Figura 6.2 - Vale Verzasca: gráfico tempo x recalque x carregamento de três sapatas........... 73

Figura 6.3 - Maison Elizabeth: gráfico tempo x recalque x carregamento de três sapatas...... 73

Figura 6.4 - Boulevard Manaíra: gráfico tempo x recalque x carregamento de três sapatas ... 74

Figura 6.5 - Stéphano: gráfico tempo x recalque x carregamento de três sapatas ................... 74

Figura 6.6 - Maison des Princes: gráfico tempo x velocidade de recalque de três sapatas ..... 75

Figura 6.8 - Maison Elizabeth: gráfico tempo x velocidade de recalque de três sapatas ........ 76

Figura 6.9 - Boulevard Manaíra: gráfico tempo x velocidade de recalque de três sapatas ..... 77

Figura 6.11 - Ajuste dos recalques medidos pela expressão de Massad (1982) ..................... 79

Figura 6.12 - S6 (Maison des Princes): pontos monitorados e curva ajustada ....................... 80

Figura 6.13 - S8 (Maison des Princes): pontos monitorados e curva ajustada ....................... 80

Figura 6.14 - S13 (Maison des Princes): pontos monitorados e curva ajustada ..................... 81

Figura 6.15 - S2 (Vale Verzasca): pontos monitorados e curva ajustada.............................. 81

Figura 6.16 - S3 (Vale Verzasca): pontos monitorados e curva ajustada.............................. 82

Figura 6.17 - S14 (Vale Verzasca): pontos monitorados e curva ajustada............................ 82 
Figura 6.18 - S11 (Maison Elizabeth): pontos monitorados e curva ajustada 83

Figura 6.19 - S17 (Maison Elizabeth): pontos monitorados e curva ajustada 83

Figura 6.20 - S20 (Maison Elizabeth): pontos monitorados e curva ajustada .84

Figura 6.21 - S2a (Vale Verzasca): pontos monitorados e curva ajustada 86

Figura 6.22 - S3a (Vale Verzasca): pontos monitorados e curva ajustada 87

Figura 6.23 - Acréscimos de recalque em relação ao imediato 90

Figura 6.24 - Maison des Princes: recalques médios totais estimados de cada camada de solo subjacente natural e compactado

Figura 6.25 - Vale Verzasca: recalques médios totais estimados de cada camada de solo subjacente natural e compactado 92

Figura 6.26 - Maison Elizabeth: recalques médios totais estimados de cada camada de solo subjacente natural e compactado 92

Figura 6.27 - Boulevard Manaíra: recalques médios totais estimados de cada camada de solo subjacente natural e compactado

Figura 6.28 - Stéphano: recalques médios totais estimados de cada camada de solo subjacente natural e compactado 93

Figura 6.28 - Maison des Princes: Gráfico de $\mathrm{E}_{\mathrm{S}} \mathrm{x}$ z para solo natural e compactado 97

Figura 6.29 - Vale Verzasca: Gráfico de $E_{S}$ x z para solo natural e compactado. 97

Figura 6.30 - Maison Elizabeth: Gráfico de $\mathrm{E}_{\mathrm{S}} \mathrm{x}$ z para solo natural e compactado 98 Figura 6.31 - Maison des Princes: Redução de recalques entre solo natural e compactado.. 101 Figura 6.32 - Vale Verzasca: Redução de recalques entre solo natural e compactado 101

Figura 6.33 - Vale Verzasca: Redução de recalques entre solo natural e compactado (com S2a e S3a) 101

Figura 6.34 - Maison Elizabeth: Redução de recalques entre solo natural e compactado..... 102 


\section{LISTA DE TABELAS}

Tabela 2.1 - Importância relativa dos recalques imediato, de adensamento e secundário para

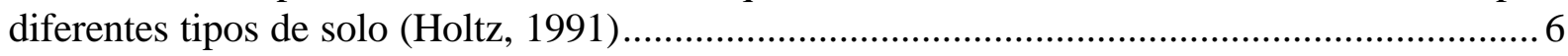

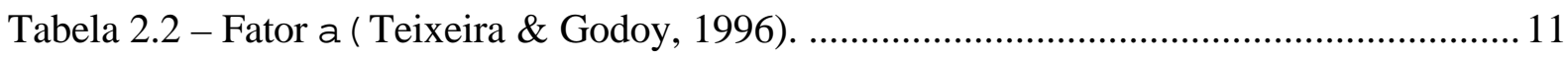

Tabela 2.3 - Coeficiente K (Teixeira \& Godoy, 1996)....................................................... 11

Tabela 2.4 - Coeficiente de Poisson (Teixeira \& Godoy, 1996)........................................... 11

Tabela 2.5 - Distribuição de cargas na estrutura (Gusmão et al., 2000).................................. 13

Tabela 4.1 - Período de monitoramento dos edifícios e fase estrutural dos ............................ 43

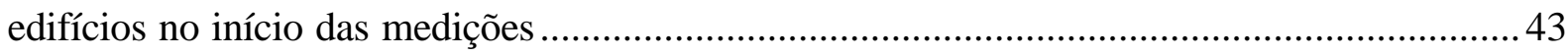

Tabela 4.2 - Período de monitoramento de cada obra ............................................................. 43

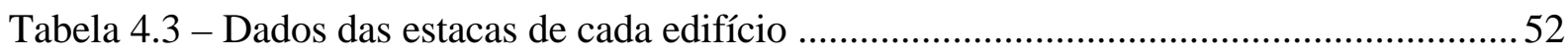

Tabela 4.4 - Sapatas cujos pilares foram monitorados em cada edifício ...............................52

Tabela 6.1 - Maison des Princes: recalques obtidos com o ajuste ....................................... 84

Tabela 6.2 - Vale Verzasca: recalques obtidos com o ajuste ............................................. 85

Tabela 6.3- Maison Elizabeth: recalques obtidos com o ajuste …...................................... 85

Tabela 6.4 - Vale Verzasca: recalques obtidos com novo ajuste ........................................ 87

Tabela 6.5 - Velocidades de recalque obtidas para o período sem monitoramento................. 88

Tabela 6.6 - Acréscimos de recalque após o término da construção ..................................... 89

Tabela 6.7 - Reduções de recalque médio estimado para as camadas .................................. 95

Tabela 6.8 - Recalques estimados e obtidos com o monitoramento e extrapolações .............. 96

Tabela 6.9- Módulo corrigido e calculado pela correlação e ábacos de Alves et al. (2000)...99

Tabela 6.10 - Maison des Princes: recalques estimados para o solo natural e obtidos com o

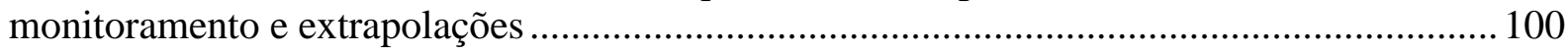

Tabela 6.11 - Vale Verzasca: recalques estimados para o solo natural e obtidos com o monitoramento e extrapolações

Tabela 6.12- Maison Elizabeth: recalques estimados para o solo natural e obtidos com o monitoramento e extrapolações .

Tabela A.1 - Carga de projeto atuante em cada sapata dos cinco edifícios 


\section{Introdução}

As estacas de compactação, também conhecidas como estacas de areia ou granulares, constituem um processo de melhoria de solos no qual uma mistura de materiais como areia, cimento e/ou brita é introduzida em terrenos arenosos por meio de aplicação de grandes energias de compactação. Esta prática é muito comum em algumas cidades do litoral nordestino, principalmente João Pessoa e Recife, onde geralmente são utilizados bate-estacas do tipo Strauss e a execução da estaca é semelhante a do tipo Franki.

O processo de compactação promove a densificação do solo adjacente, assim como um aumento de resistência e diminuição de compressibilidade. Tais efeitos contribuem para uma majoração de capacidade de carga e redução de recalques, viabilizando a utilização de sapatas em alguns casos de edifícios em regiões que não permitiriam este tipo de fundação. Na região 
mencionada, por hipótese de projeto, costuma-se considerar que a estaca não trabalha como elemento estrutural de fundação, mas sim como parte do solo melhorado.

No caso específico de João Pessoa, apesar da utilização dessa solução em diversas obras, ainda são poucos os trabalhos a abordar o comportamento de solos melhorados com estacas de areia. Os projetos relacionados a este assunto são baseados em experiência profissional dos engenheiros atuantes na área. Além de sondagens SPT executadas antes e após a compactação, poucos ensaios in-situ ou monitoramento com medições de recalque dos pilares tem sido realizados. Conseqüentemente, tornam-se raros os dados disponíveis que permitam a avaliação do desempenho das obras, assim como um melhor entendimento dos efeitos da melhoria.

Em pesquisa anterior, realizada por Soares (2002), já se comprovou a majoração da capacidade de carga dos solos compactados por meio de prova de carga em placa. Neste trabalho, são analisados os recalques de cinco edifícios sobre solo melhorado com estacas de compactação na cidade de João Pessoa - PB. Três deles foram monitorados após o início das construções, durante três anos, de fevereiro de 2001 a fevereiro de 2004. Dois continuam sendo monitorados, desde o início de suas construções, em setembro e outubro de 2004.

É analisada a eficácia desse processo de melhoria do solo na redução do recalque dos edifícios. São comparados os resultados obtidos por meio do monitoramento com recalques estimados para a situação hipotética dos edifícios em solo natural, sem compactação. 


\section{2}

\section{$\underline{\text { Revisão Bibliográfica }}$}

\subsection{Recalques}

Em projetos de edificações, é da maior importância prever como os recalques se desenvolverão com o tempo. De acordo com Aoki (2000), o desempenho de uma obra de engenharia civil ao longo de sua vida útil, especialmente da sua fundação, depende do grau de alteração do maciço de solo durante a fase de execução desta última. $\mathrm{O}$ autor acrescenta que o comportamento da fundação sob ação da carga de serviço pode ser analisado através da curva carga-tempo-recalque dos apoios da obra.

Segundo Reis (2000), a compressibilidade dos solos em função do tempo aparece no fenômeno da interação estrutura-solo como principal agente de desequilíbrio, pois a maneira 
como os recalques evoluem e se estabilizam determina a importância ou a gravidade dos danos causados por estes recalques à superestrutura.

A NBR-6122/96 estabelece que nas obras em que as cargas mais importantes são verticais, a medição dos recalques constitui o recurso fundamental para a observação do comportamento da obra. A norma acrescenta que tal medida tem como objetivo permitir a comparação de valores medidos com valores calculados, visando o aperfeiçoamento dos métodos de previsão de recalques.

Apesar disso, Danziger et al. (2000) afirmam que a prática brasileira de fundações consiste em realizar controle de recalques apenas em situações em que são observados problemas em edificações, tais com trincas ou rachaduras. Eles enfatizam a importância da medida dos recalques desde o início da construção como um controle de qualidade das fundações.

Entre os diversos autores a mencionar os tipos de recalque (Golder, 1971), Velloso \& Lopes (2004) citam o recalque instantâneo ou imediato como o que ocorre imediatamente após o carregamento, indicado como $\rho_{i}$ na Figura 2.1. Este recalque é proveniente de deformações a volume constante (distorções, sem redução do índice de vazios) e que se processa quase que simultaneamente à aplicação do carregamento, em condições nãodrenadas em argilas e condições drenadas em areias. A parcela de recalque que ocorre com o tempo é indicada como $\rho_{t}$ na mesma figura.

Assim, o recalque total ou final seria:

$$
\rho_{f}=\rho_{i}+\rho_{t}
$$




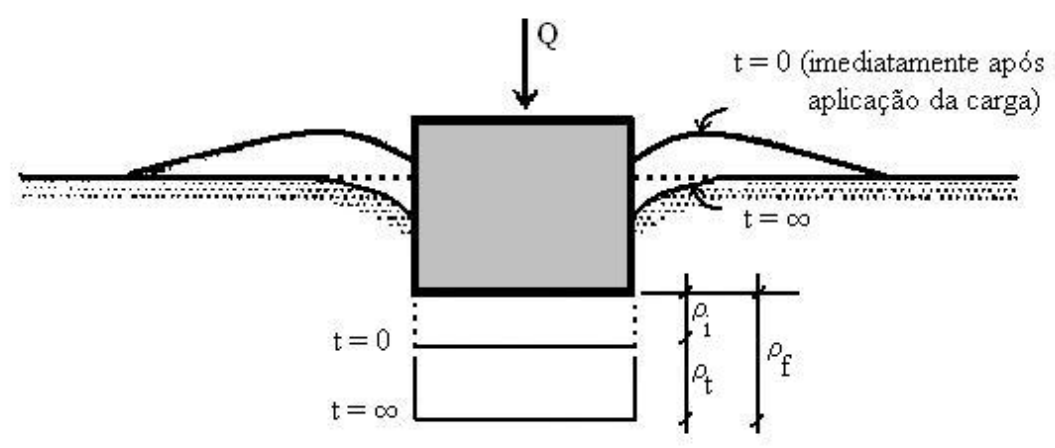

Figura 2.1 - Recalques de uma fundação superficial sob carga vertical centrada (Velloso \& Lopes, 2004).

Velloso \& Lopes (2004) acrescentam que a parcela de recalque que se processa com o tempo se deve ao adensamento (migração de água dos poros com conseqüente redução no índice de vazios) e a fenômenos viscosos (creep). Este último, também chamado de fluência, é comumente tratado como adensamento secundário.

Então:

$$
\rho_{t}=\rho_{a}+\rho_{v}
$$

em que:

$$
\begin{aligned}
& \rho_{a}=\text { parcela devida ao adensamento } \\
& \rho_{v}=\text { parcela devida a fenômenos viscosos. }
\end{aligned}
$$

Os autores afirmam que em solos de drenagem rápida, $\rho_{f}$ ocorre relativamente rápido, pois não há praticamente geração de excessos de pressão neutra com o carregamento.

Holtz (1991) ilustra a importância relativa de cada tipo de recalque nas diferentes variedades de solo na Tabela 2.1: 
Tabela 2.1 - Importância relativa dos recalques imediato, de adensamento e secundário para diferentes tipos de solo (Holtz, 1991)

Tipo de Solo Recalque Imediato Recalque por Adensamento Adensamento Secundário

\begin{tabular}{cccc}
\hline Areias & Sim & Não & Não \\
\hline Argilas & Possivelmente & Sim & Possivelmente \\
\hline Solos & Possivelmente & Possivelmente (não) & Sim \\
\hline
\end{tabular}

Entretanto, Schmertmann (1970) constata o acréscimo de recalque com o tempo, também em areias, de maneira a sugerir a ocorrência de algum tipo de fluência, como efeito similar ao adensamento secundário em argilas. Também Vargas e Leme de Morais (1989) registram a ocorrência de parcela significativa de recalques em areias após a construção, por efeito de creep.

\subsubsection{Metodologias de Cálculo}

Dentre as diversas metodologias existentes para cálculo de recalques, abordam-se aqui as utilizadas na pesquisa desenvolvida.

O método proposto por Schmertmann (1970) permite a previsão de recalques no caso de sapatas rígidas isoladas apoiadas em areia. É considerado um semi-espaço elástico, isotrópico e homogêneo. A deformação vertical $e_{z}$, sob o centro do carregamento, à profundidade $\mathrm{z}$, é expressa em função de um carregamento uniforme $\mathrm{s}$ e do módulo de deformabilidade do solo E:

$$
\varepsilon_{z}=\frac{\sigma}{E} I_{z}
$$


em que Iz é um fator de influência na deformação e encontrado pelo gráfico mostrado na Figura2.2.

$\mathrm{O}$ autor considera as deformações ocorrentes num bulbo de profundidade $2 \mathrm{~B}$, sendo B a largura da sapata. No bulbo, a deformação máxima aconteceria a uma profundidade B/2 .

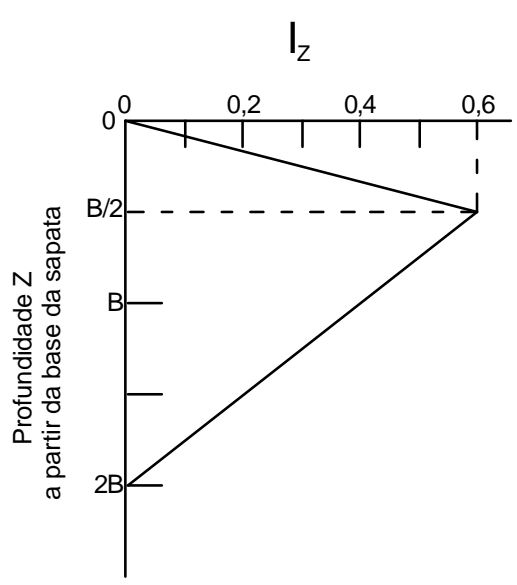

Figura 2.2 - Fator de influência na deformação vertical (Schmertmann, 1970, apud Cintra et al., 2003).

$\mathrm{O}$ autor define o fator de correção $\mathrm{C}_{1}$ que leva em consideração a influência do embutimento da sapata:

$$
C_{1}=1-0,5 *\left(\frac{q}{\sigma^{*}}\right) \geq 0,5
$$

em que q é a tensão vertical efetiva na cota de apoio da fundação e $\sigma^{*}$ é a tensão líquida aplicada pela sapata $\left(\sigma^{*}=\mathrm{s}-\mathrm{q}\right)$.

Schmertmann (1970) observa que outra parcela de recalque em areias, além do imediato, se desenvolve com o tempo, e adota outro fator de correção, chamado $\mathrm{C}_{2}$, dado por:

$$
C_{2}=1+0,2 \log \left(\frac{t}{0,1}\right)
$$


em que $\mathrm{t}=$ tempo em anos.

Considerando a presença de $\mathrm{n}$ camadas homogêneas na profundidade de 0 a $2 \mathrm{~B}$ e incluindo os efeitos do tempo e do embutimento, o recalque resultaria em:

$$
\rho=C_{1} \cdot C_{2} \cdot \sigma^{*} \cdot \sum_{i=1}^{n}\left(\frac{I z}{E}\right) \Delta z_{i}
$$

em que:

$$
\begin{aligned}
& \mathrm{I}_{\mathrm{Z}}=\mathrm{o} \text { fator de influência na deformação à meia-altura da i-ésima camada; } \\
& \mathrm{E}=\text { módulo de deformabilidade da iésima camada de espessura } \Delta \mathrm{z}_{\mathrm{i}} .
\end{aligned}
$$

Posteriormente, Schmertmann et al.(1978) acrescentaram alterações com o intuito de separar os casos de sapata corrida e de sapata quadrada por meio de dois novos diagramas referentes à distribuição do fator de influência. Para o primeiro caso, o valor máximo de $\mathrm{I}_{z}$ ocorre em $\mathrm{z}=\mathrm{B}$, enquanto que no segundo caso, em $\mathrm{z}=\mathrm{B} / 2$, e pode ser calculado pela expressão:

$$
I_{z \max x}=0,5+0,1 \sqrt{\frac{\sigma^{*}}{\sigma_{v}}}
$$

na qual $\mathrm{S}_{\mathrm{v}}$ é a tensão vertical efetiva na profundidade correspondente a $\mathrm{Z}_{\text {máx }}$. Para sapata corrida, o novo diagrama vai até $4 \mathrm{~B}$. Na profundidade $\mathrm{z}=0$, o valor de $\mathrm{I}_{\mathrm{z}}$ nos dois diagramas não é nulo, sendo 0,1 para sapata quadrada e 0,2 para sapata corrida. Os diagramas são mostrados na Figura 2.3 


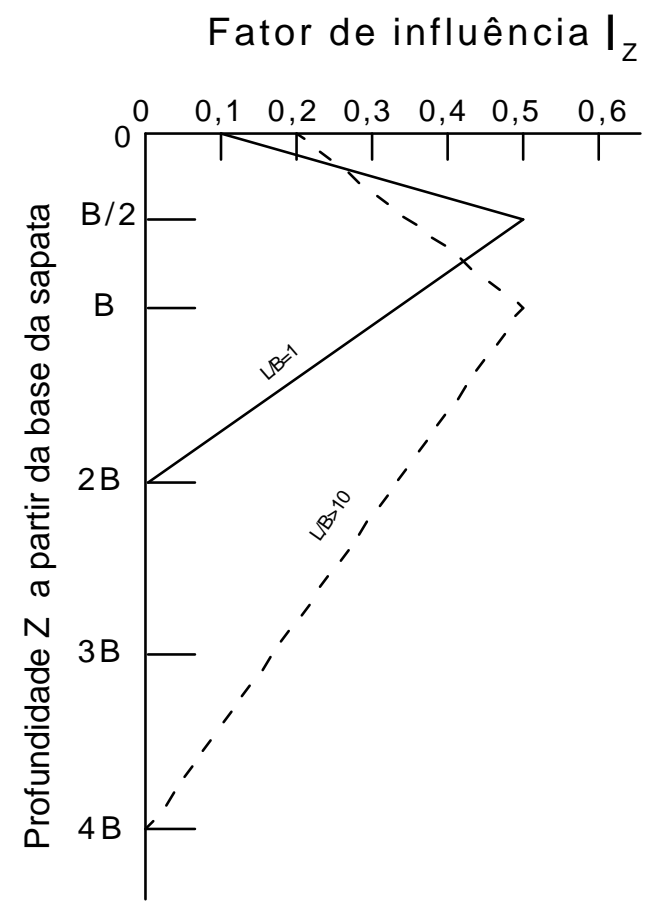

Figura 2.3 - Fator de influência na deformação vertical (Schmertmann, 1978, apud Cintra et al., 2003).

No método Aoki - Lopes (1975), o maciço é considerado como meio tridimensional, elástico, estratificado e semi-infinito. Permite-se a consideração de qualquer geometria de carregamento.

A carga transmitida ao solo pelo elemento estrutural de fundação é discretizada em um sistema estaticamente equivalente de cargas pontuais. Pode-se então admitir uma superfície carregada em trechos com a ocorrência de cargas concentradas.

Considerando uma carga concentrada vertical, as equações de Mindlin (1936) apud Aoki e Lopes (1975) representam o estado de tensões em qualquer ponto do semi-espaço infinito, assim como o deslocamento vertical desse ponto. No método Aoki e Lopes, é feita a integração numérica da expressão que representa o deslocamento vertical do ponto, obtendose o recalque. 
As contribuições das cargas discretizadas no valor total dos recalques são consideradas através da superposição dos efeitos, levando-se em conta, então, a influência do carregamento dos outros elementos estruturais de fundação.

A estratigrafia do maciço de solos é considerada por meio da técnica de Steinbrenner (1934) apud Aoki e Lopes (1975), que possibilita a determinação, pelos deslocamentos do topo e base de cada camada, da redução de espessura dessa camada. A soma de todas as reduções de espessura é o recalque total do maciço de solos.

Com o método, Aoki e Lopes (1975) desenvolvem um programa em linguagem Fortran. Posteriormente, Reis (2000) elabora um programa na mesma linguagem para o caso específico de previsão de recalque em sapatas.

O programa de Reis (2000) considera o carregamento vertical das sapatas, admitindose sua distribuição no solo por meio de um diagrama de tensões de contato uniformemente distribuídas.

São fornecidos, como dados de entrada, as cargas de projeto de cada sapata, assim como as dimensões, coordenadas e cotas de assentamento das mesmas. Em relação ao solo, fornecem-se os números de camadas componentes do perfil geotécnico e suas características como espessura, profundidade, módulo de deformabilidade (E) e coeficiente de Poisson (n).

\subsubsection{Parâmetros de deformabilidade}

Teixeira \& Godoy (1996) propõem a seguinte correlação para a estimativa do módulo de deformabilidade quando não se dispõem de dados de ensaios de laboratórios nem de prova de carga sobre placa:

$$
\mathrm{E}_{0}=\mathrm{a} \mathrm{K} \mathrm{N}_{\mathrm{SPT}}
$$


em que a é um fator de correlação e $K$ um coeficiente que relaciona a resistência de ponta do cone $\left(\mathrm{q}_{\mathrm{c}}\right)$ com o índice de resistência a penetração $\left(\mathrm{N}_{\mathrm{SPT}}\right)$ da sondagem SPT, cujos valores, em função do tipo de solo, são apresentados nas Tabelas 2.2 e 2.3, respectivamente.

Tabela 2.2 - Fator a (Teixeira \& Godoy, 1996).

\begin{tabular}{ll}
\hline Solo & $\mathbf{a}$ \\
\hline Areia & 3 \\
\hline Silte & 5 \\
\hline Argila & 7 \\
\hline
\end{tabular}

Tabela 2.3 - Coeficiente K (Teixeira \& Godoy, 1996).

\begin{tabular}{cc}
\hline Solo & K (MPa) \\
\hline Areia com pedregulhos & 1,1 \\
\hline Areia & 0,9 \\
\hline Areia siltosa & 0,7 \\
\hline Areia argilosa & 0,55 \\
\hline Silte arenoso & 0,45 \\
\hline Silte & 0,35 \\
\hline Argila arenosa & 0,3 \\
\hline Silte argiloso & 0,25 \\
\hline Argila siltosa & 0,2 \\
\hline
\end{tabular}

A Tabela 2.4 apresenta valores típicos do coeficiente de Poisson em função do tipo de solo, também apresentados por Teixeira \& Godoy (1996).

Tabela 2.4 - Coeficiente de Poisson (Teixeira \& Godoy, 1996). 


\begin{tabular}{cc}
\hline Solo & $\mathbf{n}$ \\
\hline Areia pouco compacta & 0,2 \\
\hline Areia compacta & 0,4 \\
\hline Silte & $0,3-0,5$ \\
\hline Argila saturada & $0,4-0,5$ \\
\hline Argila não saturada & $0,1-0,3$ \\
\hline
\end{tabular}

\subsubsection{Indeformável}

Assim como todos os tipos de análise necessitam de uma perspectiva comum para fins de avaliação, o estudo da interação estrutura-solo demanda um sistema de referência comum. Aoki (1997) acrescenta que, além deste sistema de referência, é necessária uma visão integrada das diferentes formas dos elementos que compõem os sistemas envolvidos em determinadas situações, sejam eles o estrutural e o geotécnico.

O autor propõe, para o caso do modelo de transferência de carga no qual o maciço de solos é considerado linear e as cargas aplicadas ao longo da interface estaca - solo são compatíveis com as resistências últimas das camadas atravessadas, o uso da referência através de um eixo comum. Tal eixo é colocado sobre a superfície do indeslocável, abaixo do qual podem-se desprezar as deformações devidas às cargas aplicadas ao maciço. Considera-se então a ação da carga transmitida ao maciço de solos, ao longo e sob a base dos elementos estruturais de fundação, e os recalques decorrentes da deformação do maciço.

Dado um perfil com as características de deformabilidade das várias camadas, questiona-se, então, em que posição se situaria esse eixo. Cintra et al. (2003) propõem a consideração de um significado relativo para o indeformável, em vez do significado absoluto. 
Os autores sugerem que se considere como última subcamada de interesse de um perfil a que apresentar recalque inferior a $10 \%$ do recalque total (até essa subcamada, inclusive). Assim, a posição do indeformável é obtida caso a caso.

\subsubsection{Carregamento}

Em trabalho que abordou medições de recalque de edifícios sobre solo melhorado com estacas de compactação em Recife, Gusmão et al. (2000) apresentam a distribuição de cargas contida na Tabela 2.5. As cargas são estimadas proporcionalmente ao número de pavimentos completados (concreto, alvenaria, revestimento, pisos, etc.).

Tabela 2.5 - Distribuição de cargas na estrutura (Gusmão et al., 2000)

\begin{tabular}{|c|c|}
\hline Tipo & Carregamento parcial $(\%)^{*}$ \\
\hline Estrutura de concreto armado & 40,0 \\
\hline Alvenarias & 20,0 \\
\hline Revestimento externo & 7,5 \\
\hline Revestimento interno & 7,5 \\
\hline Pisos & 10,0 \\
\hline Sobrecargas & 15,0 \\
\hline TOTAL & 100,0 \\
\hline
\end{tabular}

*Em relação ao carregamento total

\subsubsection{Recalque admissível}

A NBR 6122/96 define como tensão admissível a que provoca apenas recalques que a construção pode suportar sem inconvenientes, afirmando que os recalques diferenciais específicos (dados por $\delta / l$, em que $\delta$ é o recalque diferencial entre dois pilares e $l$ a distância 
entre eles) são os que geralmente podem prejudicar a estabilidade ou funcionalidade da construção. A norma acrescenta que os deslocamentos admissíveis máximos suportados pela estrutura devem ser definidos pelos projetistas envolvidos.

Entretanto, o limite que separa o admissível do inadmissível, ao se tratar de recalques, mostra-se uma questão subjetiva.

Teixeira \& Godoy (1996) indicam que a fixação da tensão admissível, pelo critério de recalques admissíveis, implica na adoção de uma tensão tal que conduza a fundação a recalques que a superestrutura possa suportar. Afirmam que é o critério que governa a maioria dos problemas práticos, sendo também o mais difícil de ser avaliado, em virtude da dificuldade na estimativa dos recalques a que estará sujeita a fundação projetada.

Segundo os autores, mesmo para valores exagerados de recalques absolutos, uma estrutura não sofreria danos caso os recalques fossem uniformes. Acrescentam que esta hipótese, entretanto, não ocorre na prática, observando-se o aparecimento de recalques diferenciais seja por excentricidade de cargas ou heterogeneidade do solo. Afirmam ainda que a limitação do recalque absoluto é um dos meios de limitar também o recalque diferencial entre dois pilares, que, por sua vez, influencia os valores do que os autores chamam de distorção angular, definida pela rotação da linha ligando dois pontos de uma fundação depois de descontado o desaprumo.

Skempton \& MacDonald (1956), em pesquisa com dados de recalques de 98 edificações, sugerem como valor limite de distorção angular o de 1/300 para o aparecimento de trincas em paredes de edifícios.

Novais Ferreira (1976), em trabalho sobre os diversos tipos e aspectos de recalque (recalque total, inclinação, recalque diferencial e distorção), adverte que a distorção angular 
usada por Skempton \& MacDonald e outros autores é de fato o recalque diferencial específico $(\delta / l)$, com a correção da inclinação quando necessário.

Golder (1971) discute os valores de distorções angulares introduzidos por Skempton \& McDonald em 1956. A dificuldade de se classificar edificações em grupos com mesmas características estruturais e susceptibilidade a danos é mencionada, assim como o fato do Código Russo fornecer maiores valores de $\delta / l$ para argilas do que para areias. Segundo o autor, isso se deve, presumivelmente, à maior quantidade de tempo para a ocorrência de recalques em argilas, e à fluência dos materiais constituintes das estruturas permitir algum alívio de tensões.

Terzaghi \& Peck (1967) observam que o recalque diferencial, nos casos de sapatas contínuas carregadas uniformemente e sapatas isoladas de aproximadamente mesmas dimensões, geralmente não excede $50 \%$ do maior recalque medido, em areias. Os autores acrescentam que sob condições extremas envolvendo fundações por sapatas com tamanhos e embutimentos muito diferentes, o recalque diferencial geralmente não excede $75 \%$ do recalque máximo. Segundo os autores, um recalque diferencial da ordem de $20 \mathrm{~mm}$ pode ser tolerado pela maioria das estruturas comuns como edifícios de escritórios, residenciais e industriais. Conseqüentemente, aconselham como valor de recalque admissível para areias o de $25 \mathrm{~mm}$.

Alonso (1995) adverte que além da necessidade de se controlar os recalques diferenciais para mantê-los dentro de valores que não causem danos à estrutura, também a velocidade de recalque deve ser controlada. O autor apresenta valores utilizados em sua atividade profissional.

Em prédios construídos há mais de cinco anos e considerados estabilizados, Alonso(1995) menciona ser comum registrarem-se velocidades dos recalques inferiores a 20 
$\mu \mathrm{m} /$ dia. Nesses mesmos prédios, velocidades entre 20 e $40 \mu \mathrm{m} /$ dia são consideradas de moderadas a altas e acima de $40 \mu \mathrm{m} /$ dia são consideradas muito altas e preocupantes. Em prédios construídos há mais de um ano e menos de cinco são aceitáveis velocidades de 30 $\mu \mathrm{m} / \mathrm{dia}$.

Para prédios em construção e apoiados em fundação rasa, podem ser considerados normais os valores de velocidades de até $200 \mu \mathrm{m} /$ dia.

Além da observação das velocidades, o autor também sugere que sejam feitas “curvas de igual recalque", que seriam de grande importância por permitir uma visão global do comportamento da obra.

\subsubsection{Extrapolação de curvas tempo x recalque}

Asaoka (1978) propõe um método gráfico para o acompanhamento de recalques ao longo do tempo. O método permite, a partir de curvas tempo x recalque medidas, prever o recalque final e também a estimativa do coeficiente de adensamento $\left(\mathrm{C}_{\mathrm{v}}\right)$, sem a necessidade de medidas de recalque desde o início do processo de adensamento.

Massad (1982), em trabalho que divulga esse método gráfico, demonstra a simplificação da expressão proposta por Asaoka, que resulta, para U (porcentagem de adensamento) $>60 \%$, em:

$$
?^{\prime}=?^{\prime}{ }_{e s t}\left(1-\mathrm{e}^{(-\mathrm{at}+\beta)}\right)
$$

em que:

$$
\begin{aligned}
& \mathrm{t}=\text { tempo; } \\
& \rho^{\prime}{ }_{\text {est }}=\text { recalque estabilizado }(\mathrm{t}=\infty) ;
\end{aligned}
$$




$$
\begin{aligned}
& \rho^{\prime}=\text { recalque em um tempo } \mathrm{t} \\
& \mathrm{a}=\frac{2,47 * C_{V}}{H_{d}^{2}}, \text { com } \mathrm{H}_{\mathrm{d}} \text { sendo a altura de drenagem; } \\
& \beta=-0,2102 .
\end{aligned}
$$

Segundo Aoki (1982), a expressão apresentada corresponde à equação de Van der Veen generalizada. Van der Veen (1953) propôs, para o caso de extrapolação de recalque com a carga, a equação:

$$
\mathrm{P}=\mathrm{R}\left(1-\mathrm{e}^{-\mathrm{a} \rho}\right)
$$

em que:

$$
\begin{aligned}
& \mathrm{P} \text { - carga; } \\
& \mathrm{R} \text { - capacidade de carga; } \\
& \text { a - coeficiente de forma da curva; } \\
& \rho \text { - recalque. }
\end{aligned}
$$

A capacidade de carga é obtida a partir de pontos $(\mathrm{P}, \rho)$ obtidos em prova de carga. Deve-se encontrar, por tentativas, o valor de R que conduz à melhor regressão linear até que se obtenha uma reta no gráfico $-\ln \left(1-P / P_{\operatorname{máx}}\right) \times \rho$.

Aoki (1976) propõe a inclusão de um intercepto $\beta$, da reta obtida na escala semilogarítmica, no eixo dos recalques. $\mathrm{O}$ autor observa que se a curva $\mathrm{P}$ x $\rho$ não for obrigada a passar pela origem, pode-se melhorar a regressão. A expressão, mencionada pelo autor em 1982 como a de Van der Veen generalizada, resulta em:

$$
P=R\left(1-e^{-a \rho+\beta}\right)
$$


Originalmente, o valor de $\mathrm{R}$ era encontrado graficamente. Atualmente, já existem programas para calculadoras e computadores.

Aoki (1982) afirma que, por experiência própria, a expressão demonstrada por Massad (1982) aplica-se igualmente à extrapolação de curva tempo x recalque obtidas em controle de recalques usuais, utilizando-se o procedimento de Van der Veen para estimativa do recalque estabilizado.

\subsubsection{Interação estrutura-solo}

Convencionalmente, a hipótese dos apoios fixos para pilares ainda é admitida em projetos estruturais, tanto no cálculo das cargas atuantes nas fundações como no dimensionamento dos elementos estruturais. Além disso, a maioria dos projetos de fundação leva em conta somente as cargas de projeto, como se estas atuassem de maneira independente umas das outras.

De acordo com Gusmão (1994), cria-se um verdadeiro "fosso" entre o terreno de fundação e a estrutura, uma vez que o processo acima mencionado despreza efeitos da interação estrutura-solo provocados pela deformação do terreno e pela rigidez da estrutura: a redistribuição de esforços nos elementos estruturais, em especial das cargas nos pilares, e a diminuição dos recalques em relação aos estimados convencionalmente. Tais efeitos decorrem da solidariedade existente entre os elementos estruturais, a qual confere à estrutura uma considerável rigidez que restringe o movimento relativo entre os apoios.

O autor enfatiza ainda a influência da interação estrutura-solo em recalques de edificações, sugerindo uma análise do fenômeno através de monitoramentos de recalques, em virtude da medida de tal informação ser mais fácil e, por meio dela, a possível avaliação do surgimento de danos e escolha do tipo de fundação. 
A interação estrutura-solo promove um alívio de carga nos pilares mais carregados e uma sobrecarga nos pilares menos carregados. Devido à restrição de recalques diferenciais provocada pela rigidez da estrutura, Gusmão (1994) afirma que a deformada de recalques medida é mais suave que a estimada convencionalmente.

\subsection{Estacas de compactação}

As estacas de compactação, também conhecidas como estacas de areia ou estacas granulares, fazem parte de um processo de melhoria de solos pelo qual as mesmas são introduzidas em terrenos de baixa resistência, por meio da aplicação de grandes energias de compactação através de esforços dinâmicos ou vibração.

Materiais como areia e brita ou areia e cimento, entre outros, são empregados na execução. O método promove a densificação do solo adjacente, que acarreta melhorias em aspectos como resistência e compressibilidade.

Slocombe (1993) atribui a melhoria de tais propriedades pelo processo de compactação ao deslocamento físico das partículas dos solos, que têm o volume de vazios reduzido, aumentando a compacidade relativa e a capacidade de carga.

Madhav (1985) adiciona a esses efeitos algumas vantagens que as estacas de areia possuem sobre outros métodos de melhoria do solo:

$\rightarrow$ Aumento moderado na capacidade de carga do solo;

$\rightarrow$ Redução significativa nos recalques; 
$\rightarrow$ Em solos granulares, os recalques são acelerados, e, após a construção, minimizados;

$\rightarrow$ Instalação relativamente simples devida a prático trabalho braçal (particularmente adequado para países em desenvolvimento);

$\rightarrow$ Aumento na resistência à liquefação.

Para solos coesivos, as estacas funcionam como drenos verticais de areia, pois o uso de materiais mais grossos favorece o surgimento de fluxos de água, acelerando o adensamento. Como efeitos, obtém-se o aumento de resistência e a redução de recalques.

O método das estacas de compactação é aplicado na ex-União Soviética desde 1948, e cerca de 4,5 milhões de metros cúbicos de loess foram compactados dessa maneira (Abelev, 1975).

No Nordeste, principalmente em João Pessoa e Recife, a compactação de solos arenosos com as estacas em questão é freqüente. A majoração da capacidade de carga e redução de recalques viabilizam a utilização de sapatas em alguns casos de edifícios em regiões que não permitiriam este tipo de fundação. Por hipótese de projeto, costuma-se considerar que a estaca não trabalha como elemento estrutural de fundação, mas sim como parte do solo melhorado. Tal prática é feita de maneira empírica, baseada na experiência dos engenheiros atuantes na área.

Segundo Gusmão (2005), a técnica vem sendo utilizada com sucesso em Recife desde a década de 70. Os primeiros prédios eram projetados com tensões admissíveis de $250 \mathrm{kPa}$, enquanto hoje há prédios com tensões admissíveis de até $700 \mathrm{kPa}$. Em João Pessoa, 90\% das fundações êm sido projetadas em sapatas com melhoria prévia do solo com estacas de compactação (Passos, 2001 apud Gusmão et al., 2005). É comum a utilização de areia e brita, 
areia e cimento ou até os três materiais na execução das estacas, que chegam a alcançar cinco metros de profundidade (Soares \& Soares, 2004).

\subsubsection{Processo executivo}

No Brasil, a técnica de execução das estacas de areia é conhecida como vibrodeslocamento. Neste método, como o próprio nome sugere, o deslocamento lateral do solo natural é provocado pela cravação de um tubo de ponta fechada. Uma das subdivisões do tipo de instalação das estacas granulares por meio da cravação prévia de um tubo é o método Franki, descrito a seguir e utilizado em João Pessoa.

De acordo com Soares \& Soares (2004), inicialmente, posiciona-se o tubo de revestimento de modo a se formar um plugue de material constituinte da estaca em sua base (bucha). O tubo é então cravado dinamicamente através de impactos repetidos por golpes de pilão na bucha até a profundidade especificada de projeto. A expulsão da bucha ocorre após o tubo ser preso na torre do bate-estaca por meio de cabos de aço. Em seguida, o material granular, que pode ser areia e brita, areia e cimento ou uma mistura desses materiais, é introduzido dentro do tubo e compactado pela queda livre do pilão. Simultaneamente à introdução do material, o tubo é retirado, até a finalização do processo de densificação do solo por meio da execução da estaca. A esquematização do processo ilustra-se na Figura 2.4: 


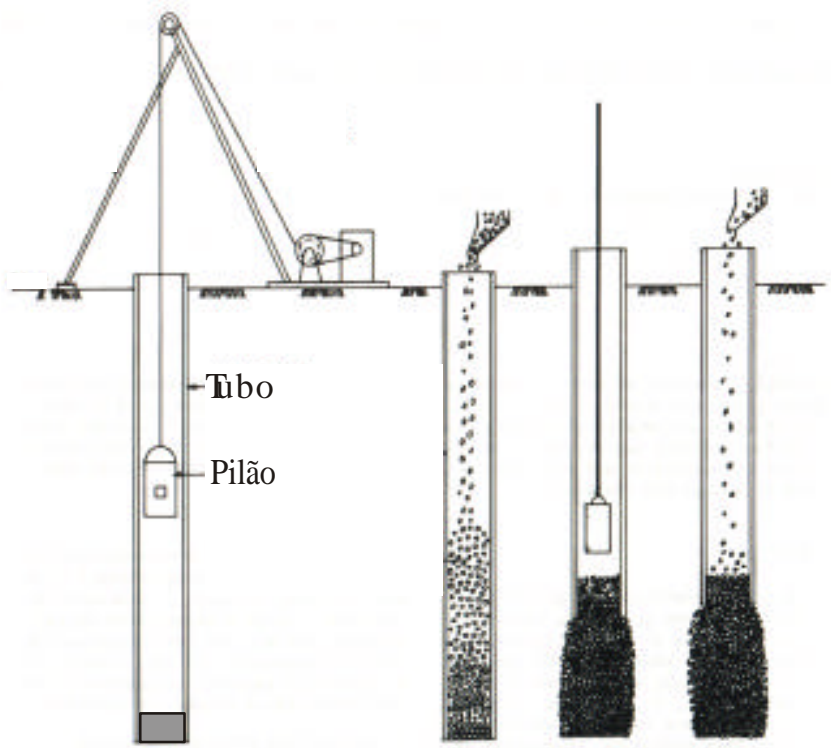

Figura 2.4 - Processo executivo de estaca de compactação por vibro-deslocamento (Bell, 1993).

Essa densificação é alcançada, segundo Bell (1993), devido ao deslocamento de material no terreno com volume igual ao da estaca e também aos efeitos de vibração decorrente do processo executivo. Gusmão Filho (1998) acrescenta ainda a essas causas a introdução de material adicional compactado no terreno.

\subsubsection{Equipamento}

Em João Pessoa, geralmente, utiliza-se na execução das estacas granulares o equipamento descrito por Soares (2002): um bate-estacas do tipo "Strauss" formado por tripé, motor, guincho acoplado a um mecanismo de movimentação, além do pilão e tubo de revestimento. Sua produtividade depende de diversos fatores, tais como: altura da torre, potência do motor, resistência de guinchos e agilidade do mecanismo de movimentação. $\mathrm{O}$ procedimento é mostrado na Figura 2.5 e algumas estacas prontas na Figura 2.6. 


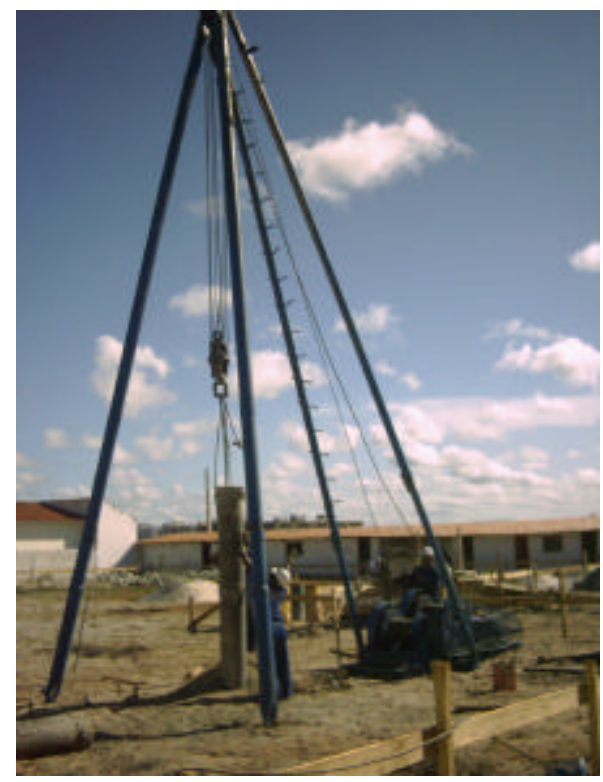

Figura 2.5 - Bate-estacas usado na execução de estacas de areia (Soares \& Soares, 2004)

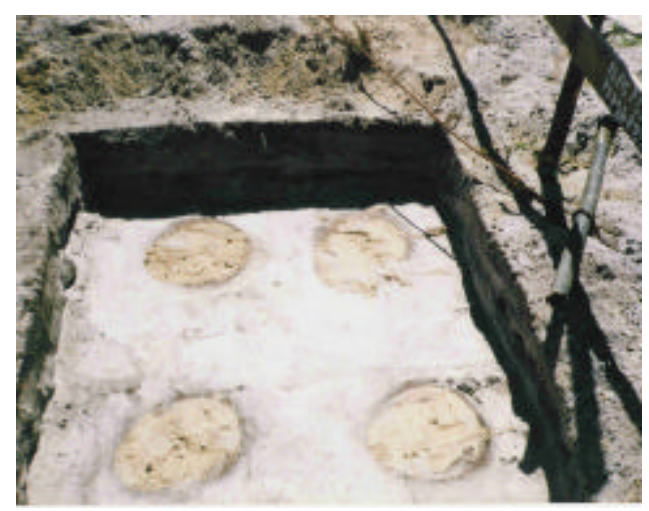

Figura 2.6 - Estacas de compactação prontas (Copesolo, 2005)

\subsubsection{Controle na execução}

O controle do processo de execução é de caráter fundamental para a análise do comportamento e desempenho das estacas de compactação. Segundo Soares (2002), devem ser coletados dados com respeito à quantidade de material injetado tanto na base quanto no fuste, especificação de equipamentos e energia utilizada, assim como a profundidade atingida deve ser registrada. 
Datye \& Nagaraju (1981) afirmam que um importante fator na avaliação do desempenho das estacas granulares é o consumo de material, que pode ser uma mistura de areia e pedra britada. Da proporção em volume de 1: 0,2 - 0,5, é possível obter uma massa bem compacta, considerando o fato de que a areia preenche os vazios correspondentes aos espaços não ocupados pela pedra britada.

Soares \& Soares (2004) mencionam como valores usuais de traço em volume da estaca:

$\rightarrow$ Estacas de areia e brita $-4: 1$.

$\rightarrow$ Estacas de cimento e areia $-1: 15-20$

$\rightarrow$ Estacas de cimento, areia e brita -1:8:4.

Segundo Wallays (1985), pode-se ainda verificar a compacidade do solo com medidas da compacidade relativa, do índice de resistência à penetração $\mathrm{N}_{\mathrm{SPT}}$ e da resistência do cone.

\subsubsection{Solo adequado à melhoria}

A resposta dos solos ao processo de compactação dinâmica muda de acordo com as suas características geotécnicas, observando-se diferenças significativas entre solos granulares e coesivos. Os efeitos da melhoria diminuem bastante quando há uma excessiva fração de finos no solo. Mitchell (1970) afirma que a eficiência da técnica de vibro deslocamento é limitada a solos que contenham quantidades de finos em torno de $20 \%$.

A Figura 2.7 mostra a faixa de ocorrência granulométrica, de terrenos naturais, em que a compactação do solo com estacas de areia é mais eficiente. Foi obtida por Gusmão Filho 
(1998) a partir de solos arenosos do Recife, nos quais, segundo o autor, foi utilizada a técnica de melhoria com resultados favoráveis à execução de edificações sobre fundações diretas.

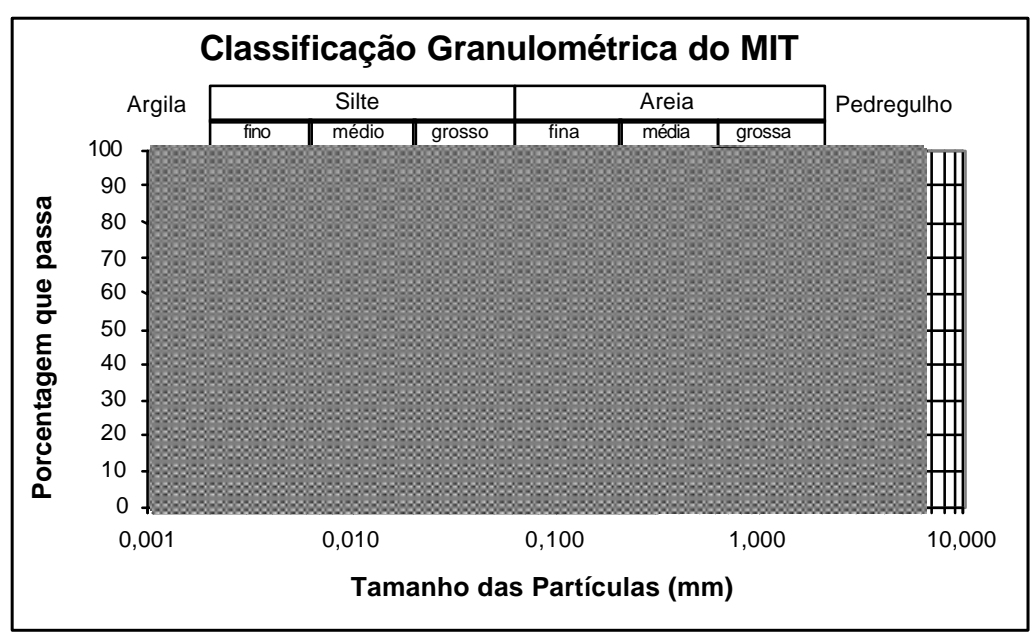

Figura 2.7 - Faixa de ocorrência em que a técnica é mais eficiente (adaptado de GUSMÃO FILHO, 1998 apud SOARES,2002 ).

No Brasil, especialmente nas regiões litorâneas do Nordeste, as características do subsolo favorecem o desempenho da técnica de melhoramento do solo com estacas de areia.

No caso de solos preponderantemente coesivos, as estacas funcionam como drenos verticais de areia, pois o uso de materiais de maior granulometria favorece o surgimento de trajetórias preferenciais de água, processo que acelera o adensamento. Como efeitos, surgem o aumento de resistência e a redução de recalques. O material introduzido forma uma coluna densa, que aumenta a rigidez e reforça o solo coesivo, diminuindo o risco de ruptura por cisalhamento sob a ação das cargas de projeto. Bouassida \& Hadhri (1995) acrescentam que, em solos moles, além do aumento da capacidade de carga, outras vantagens são obtidas como a redução de recalques e do tempo de adensamento primário. 


\subsubsection{Restrições}

Um dos fatores limitantes de resultados significativos à melhoria pelas estacas granulares é a compacidade inicial dos solos arenosos. Para camadas mais compactas constata-se a redução dos efeitos da melhoria (Gusmão, 2005; Soares \& Soares, 2004, Bicalho \& Castello, 2004), que se reve lam apreciáveis para camadas mais fofas.

A pequenas profundidades, menores que $1,5 \mathrm{~m}$, não se observam resultados consideráveis porque a ausência de confinamento pela superfície do terreno não permite uma compactação ideal, podendo ocorrer o levantamento das camadas mais superficiais sem aumento de resistência (Gusmão Filho, 1998). Tal fato já não ocorre para profundidades entre 2 e $3 \mathrm{~m}$.

Soares \& Soares (2004) afirmam que uma maneira de avaliação dos efeitos da melhoria é a realização de sondagens pós-compactação, que são realizadas, geralmente, a 2 m do furo em solo natural e, ao mesmo tempo, em uma posição simétrica entre as estacas. Os autores apresentam valores de eficiência da compactação relacionando o índice de resistência a penetração da sondagem SPT obtido para solos naturais $(\mathrm{N})$ e posteriormente compactados $\left(\mathrm{N}_{\mathrm{p}}\right)$ :

$$
\begin{aligned}
& \rightarrow \mathrm{N}_{\mathrm{p}} / \mathrm{N} \cong 3,0 \text { para } 5<\mathrm{N}<10 ; \\
& \rightarrow \mathrm{N}_{\mathrm{p}} / \mathrm{N} \cong 2,7 \text { para } 11<\mathrm{N}<18 ; \\
& \rightarrow \mathrm{N}_{\mathrm{p}} / \mathrm{N} \cong 2,1 \text { para } 19<\mathrm{N}<25 .
\end{aligned}
$$

Observam que solos com $\mathrm{N}<10$ respondem melhor ao processo de compactação. Os autores afirmam que as areias fofas têm contato intergranular menos intenso, promovendo menos resistência a uma reorganização dos grãos. 
Além das condições geotécnicas, West (1975) afirma que a exeqüibilidade do uso da melhoria do solo com estacas de areia depende de vários aspectos como tipo de estrutura, tolerância quanto aos recalques, condições ambientais etc.

\subsubsection{Disposição}

De acordo com SOARES (2000), as estacas são geralmente instaladas em malhas quadradas ou triangulares, com espaçamento em torno de 2 a 3 vezes seu diâmetro. Tais malhas podem ser dispostas de modo a abranger toda a área de projeção do prédio ou apenas as regiões sob as sapatas.

O raio de influência no qual os efeitos da compactação das estacas se fazem presentes alcança de 2 a 2,5 vezes o diâmetro delas (GUSMÃO FILHO 1998). Os serviços de compactação com essas estacas conseguem melhorar a resistência do solo até uma profundidade de 1,5 m abaixo da ponta do tubo de revestimento (Soares \& Soares, 2004).

\subsubsection{Resultados e análises de ensaios de avaliação}

SOARES (2002) analisa resultados de ensaios in situ, tais como SPT, CPT e provas de carga estática. Os ensaios foram realizados em solo natural e melhorado, com estacas de areia de 3,5 m de comprimento e $3 \mathrm{~cm}$ de diâmetro, de modo a avaliar os efeitos da compactação. $\mathrm{O}$ autor utiliza malhas de estacas espaçadas de 80,90 e $100 \mathrm{~cm}$, obtendo, entre outros, os dados contidos nas Figuras 2.8 a 2.11. 


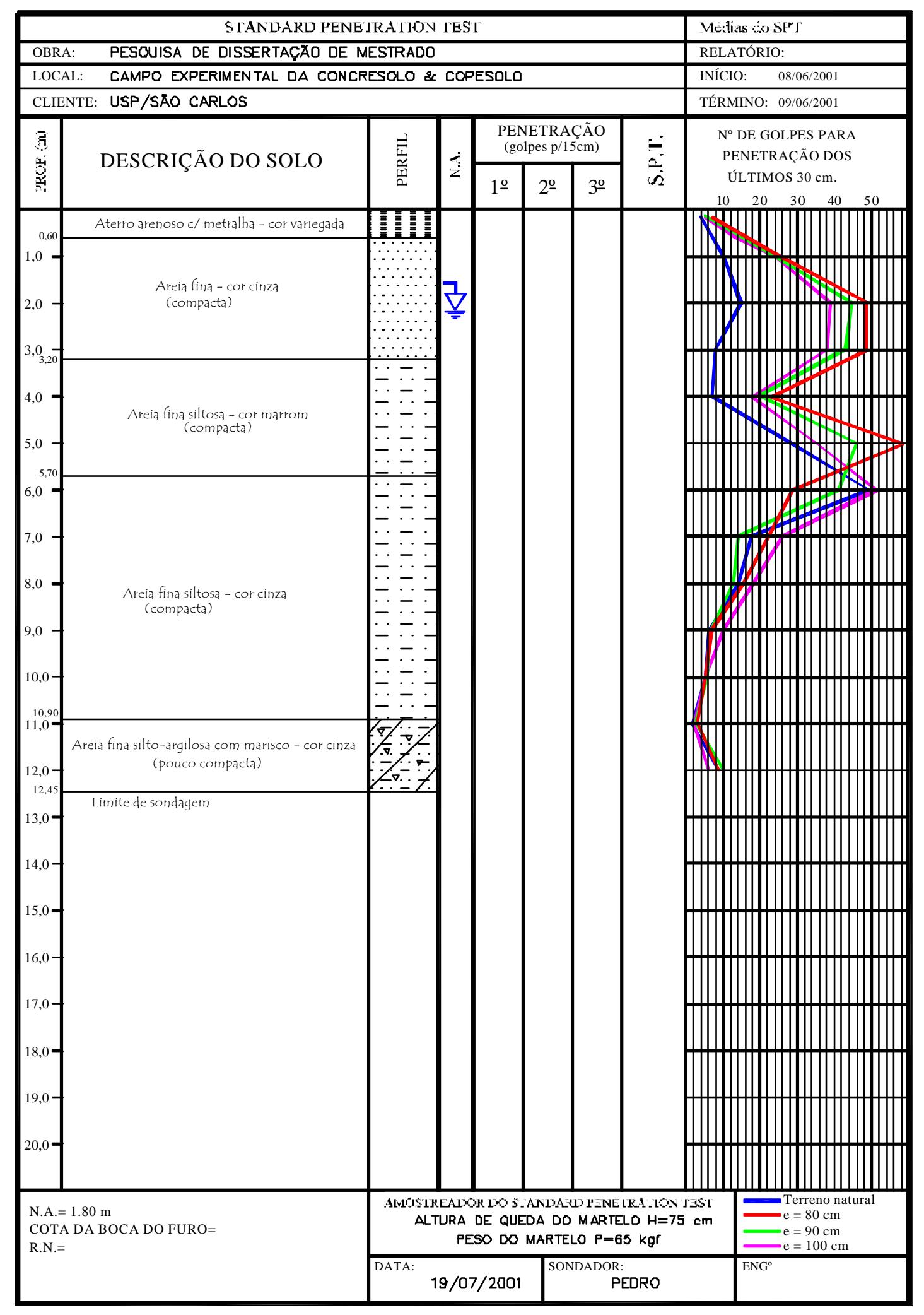

Figura 2.8 - Boletim de sondagem com os valores do índice de resistência à penetração $\mathrm{N}_{\mathrm{SPT}}$ médios, obtidos em solo natural e em malhas e estacas com espaçamento de 80,90 e $100 \mathrm{~cm}$. (SOARES, 2002). 

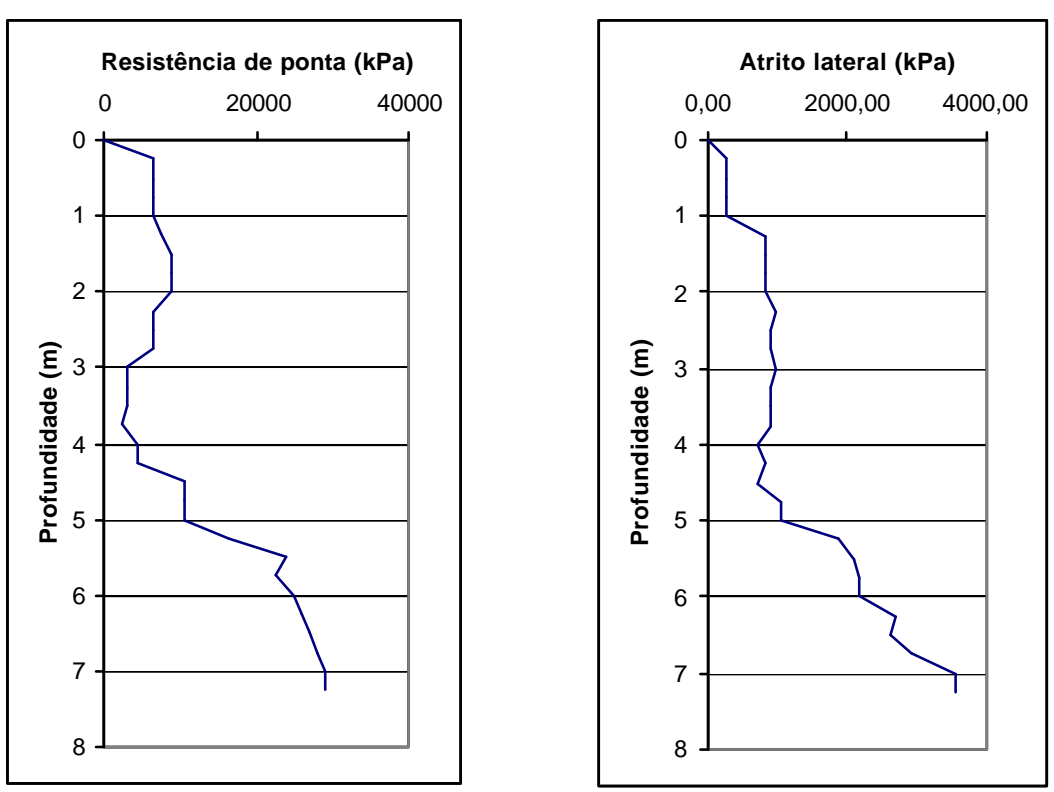

Figura 2.9 - Ensaio de cone em solo natural (SOARES, 2002).
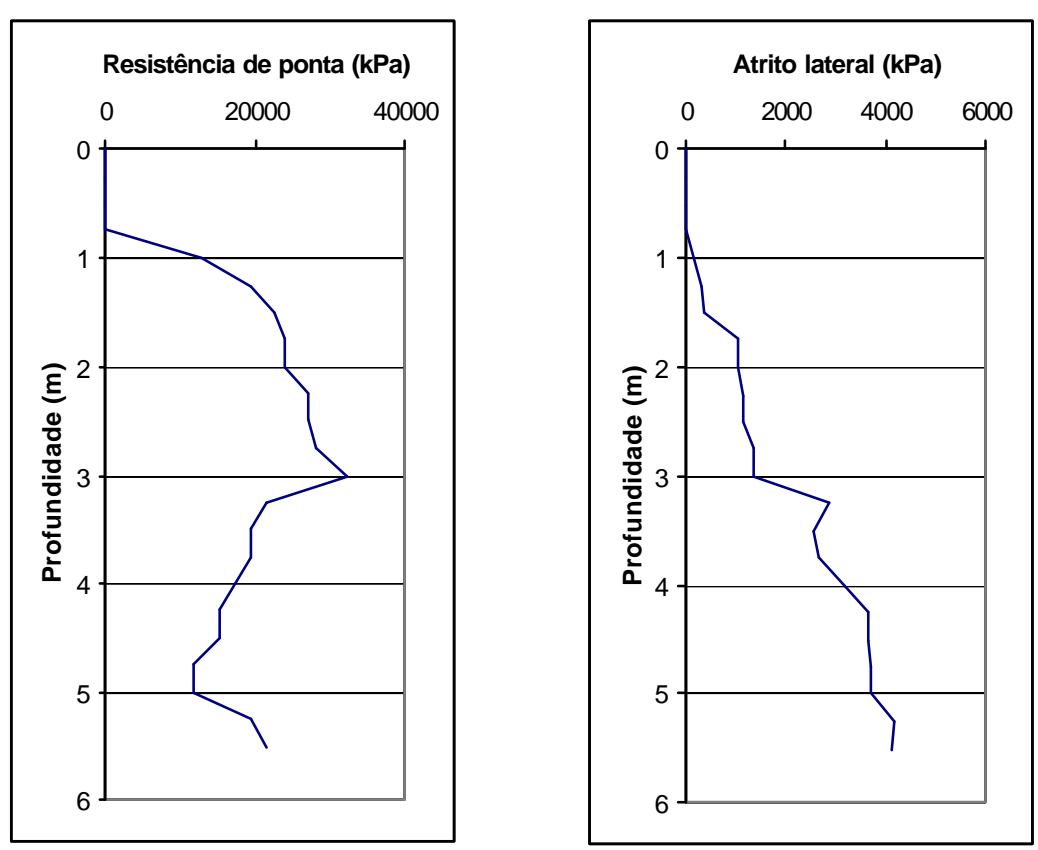

Figura 2.10 - Ensaio de cone em malha de estacas com espaçamento de $90 \mathrm{~cm}$ (SOARES, 2002) 


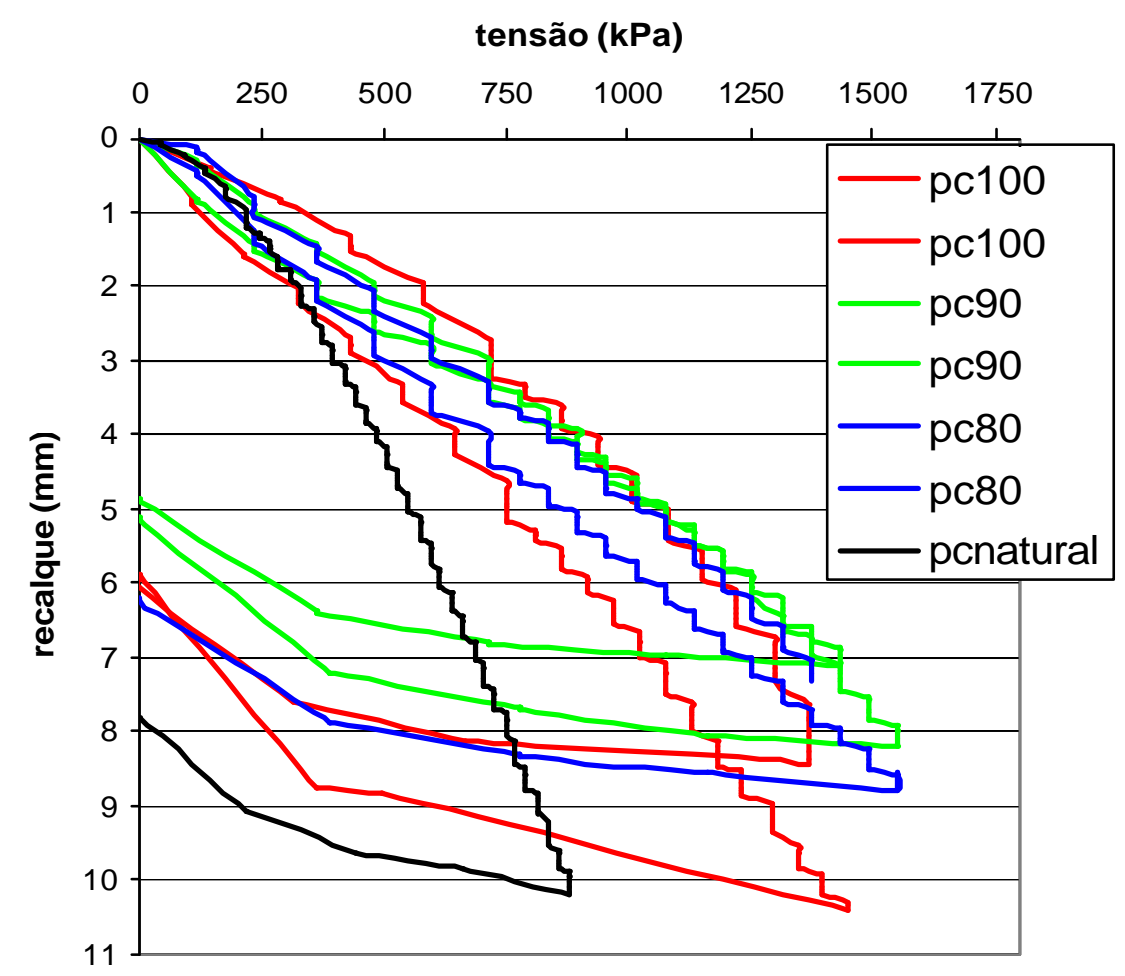

Figura 2.11 - Provas de carga realizadas em terreno natural e compactado (SOARES, 2002).

$\mathrm{O}$ autor estabelece correlações empíricas entre os valores de $\mathrm{N}_{\mathrm{SPT}}$ antes e após compactação, assim como uma previsão para capacidade de carga de fundações rasas em solos arenosos em solos melhorados com estacas de compactação, por meio dos valores de $\mathrm{N}_{\text {SPT }}$ obtidos.

A partir das correlações entre $\mathrm{N}_{\mathrm{SPT}}$ natural e compactado, o autor determina a tensão admissível para fundações por sapata em solo arenoso e compactado, mediante a seguinte fórmula de TEIXEIRA (1996), obtida para um $\gamma$ de $18 \mathrm{kN} / \mathrm{m}^{3}$, profundidade de 1,5 m e fator de segurança 3:

$$
\sigma_{\mathrm{a}}=50+(10+4 \mathrm{~B}) \mathrm{N}_{\mathrm{SPT}}
$$

em que $\sigma_{\mathrm{a}}$ é a tensão admissível (em kPa) e B é a largura da sapata (em metros), com validade no intervalo de $5<\mathrm{N}_{\mathrm{SPT}}<25$. Foi constatado que a tensão admissível elevou-se de $0,2 \mathrm{MPa}$ a 0,5 MPa, no intervalo de $\mathrm{B}=1$ a $5 \mathrm{~m}$. 


\subsubsection{Recalques}

Lucena et al. (2004) monitoraram um edifício com fundações diretas por sapatas sobre solo melhorado, em João Pessoa. O Residencial Mar da Galiléia, de 12 pavimentos, teve todos os pilares observados desde o início de sua construção. O solo era predominantemente arenoso, e a tensão admissível adotada foi de 0,5 MPa. Até a última medição obtida, correspondente a um carregamento de $53 \%$ da carga total, foi obtido o recalque médio de 4,3 mm.

Alves et al. (2000) propõem um método de projeto de fundações superficiais em solo granular fofo melhorado com estacas de compactação. Foi sugerida a correlação para obtenção do módulo de deformabilidade do terreno melhorado em função do índice de resistência a penetração da sondagem SPT $\left(\mathrm{N}_{\mathrm{SPT}}\right)$ :

$$
\mathrm{E}_{\text {solo }}=\alpha \mathrm{N}_{\mathrm{SPT}}
$$

$\mathrm{Na}$ qual $\alpha$ depende do tipo de solo e, segundo os autores, se situa em uma faixa entre 1,5 e 3,0, sendo o valor mais baixo correspondente a solos arenosos e o valor mais alto a solos finos. $\mathrm{O}$ valor 2,5 é freqüentemente encontrado em areias finas ou siltosas ou argilosas.

A partir dessa correlação, os autores apresentam ábacos que fornecem o módulo da camada equivalente melhorada, para os quais são necessários:

$\rightarrow$ A relação espaçamento/diâmetro das estacas (s/d)

$\rightarrow$ O módulo de elasticidade das estacas granulares - foram utilizados dois valores: $500 \mathrm{MPa}$, para estaca granular com cimento, e $100 \mathrm{MPa}$, para estaca granular sem cimento. A Figura 2.1 exibe o ábaco a ser usado com o valor de $500 \mathrm{MPa}$;

$\rightarrow \mathrm{O}$ módulo do terreno melhorado (obtido pela correlação mencionada anteriormente). 


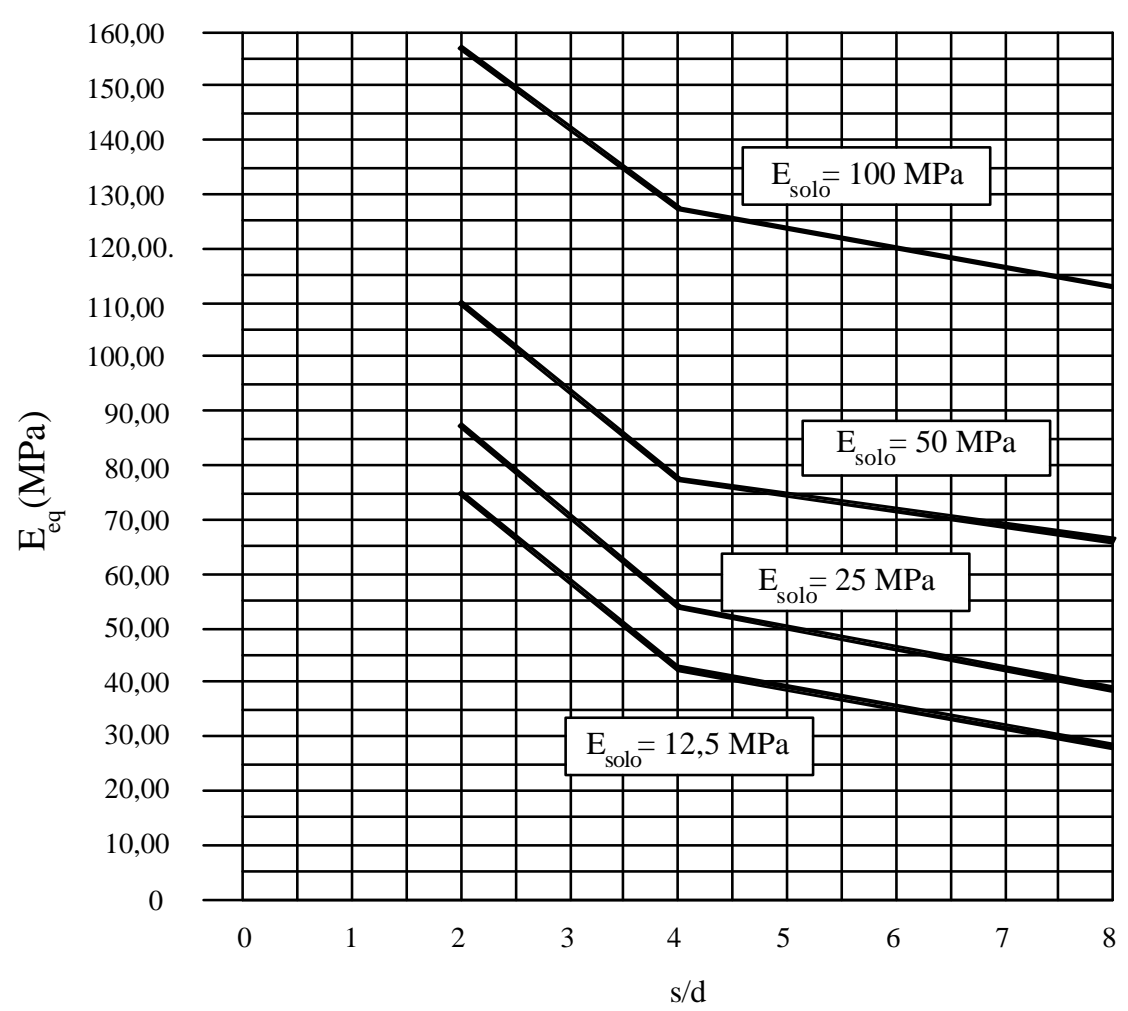

Figura 2.12 - Ábaco para cálculo do módulo equivalente para $\mathrm{E}_{\text {estaca }}=500 \mathrm{MPa}$ (Alves et al. ,2000).

Como exemplo de aplicação, os autores estimaram o recalque de uma sapata sobre solo sem estacas de compactação e sobre solo melhorado. Obtiveram o valor de $70 \mathrm{~mm}$ para a primeira situação e de $25 \mathrm{~mm}$ para a segunda, resultando numa redução de $64 \%$ do recalque.

Soares et. al (2003) também apresentam uma faixa de redução do recalque estimada para as duas situações de solo, variando de $41 \%$ a $72 \%$, de acordo com o tamanho das sapatas. Os autores utilizaram o método de Schmertmann (1970). 


\section{Caracterização Geológico -}

\section{Geotécnica}

Os edifícios analisados neste estudo localizam-se na região litorânea de João Pessoa, cujo subsolo arenoso tem favorecido o freqüente uso de estacas de compactação como melhoria de solos para a execução de fundações diretas por sapatas. As estacas tipo Franki também são comumente utilizadas nas obras locais.

De acordo com Soares (2002), a parte alta da cidade apresenta um solo mais coesivo, com predominância de siltes-argilosos e ausência de nível d'água superficial. Nessa área, os tipos de fundações mais comuns são as estacas escavadas e tubulões. Menos comuns são as fundações por estacas pré-moldadas e metálicas, estas geralmente apoiadas na rocha calcária, localizada a aproximadamente $24 \mathrm{~m}$ de profundidade. 


\subsection{Caracterização geológica}

GUSMÃO FILHO (1982), em trabalho sobre fundações no Nordeste, menciona que João Pessoa, assim como todas as capitais da região, situa-se sobre a formação sedimentar Barreiras, com sotoposição de calcários e arenitos, para chegar ao cristalino que aflora ocasionalmente.

O autor afirma que geologicamente, a planície costeira nordestina é formada por sedimentos quaternários de origem marinha em razão do avanço e retrocesso do mar que a modulou em praias ou enseadas. João Pessoa tem a linha costeira cortada por afloramentos de rocha que se erguem como testemunhos resistentes à ação erosiva, de que são exemplos os cabos e pontas.

CONCIANI et al. (1999) acrescentam que os sedimentos mencionados são constituídos por areias sobrepostas em camadas de diferentes graus de compacidade. Tal estratificação pode ter sua origem nos movimentos de transgressão e regressão do mar, ocorridos em eras passadas.

O solo superficial é predominantemente granular, sendo constituído de areias e siltes geralmente fofos $\left(\mathrm{N}_{\mathrm{SPT}}<5\right)$ (Gusmão Filho,1982).

A Figura 3.1 mostra o perfil geológico da cidade. 

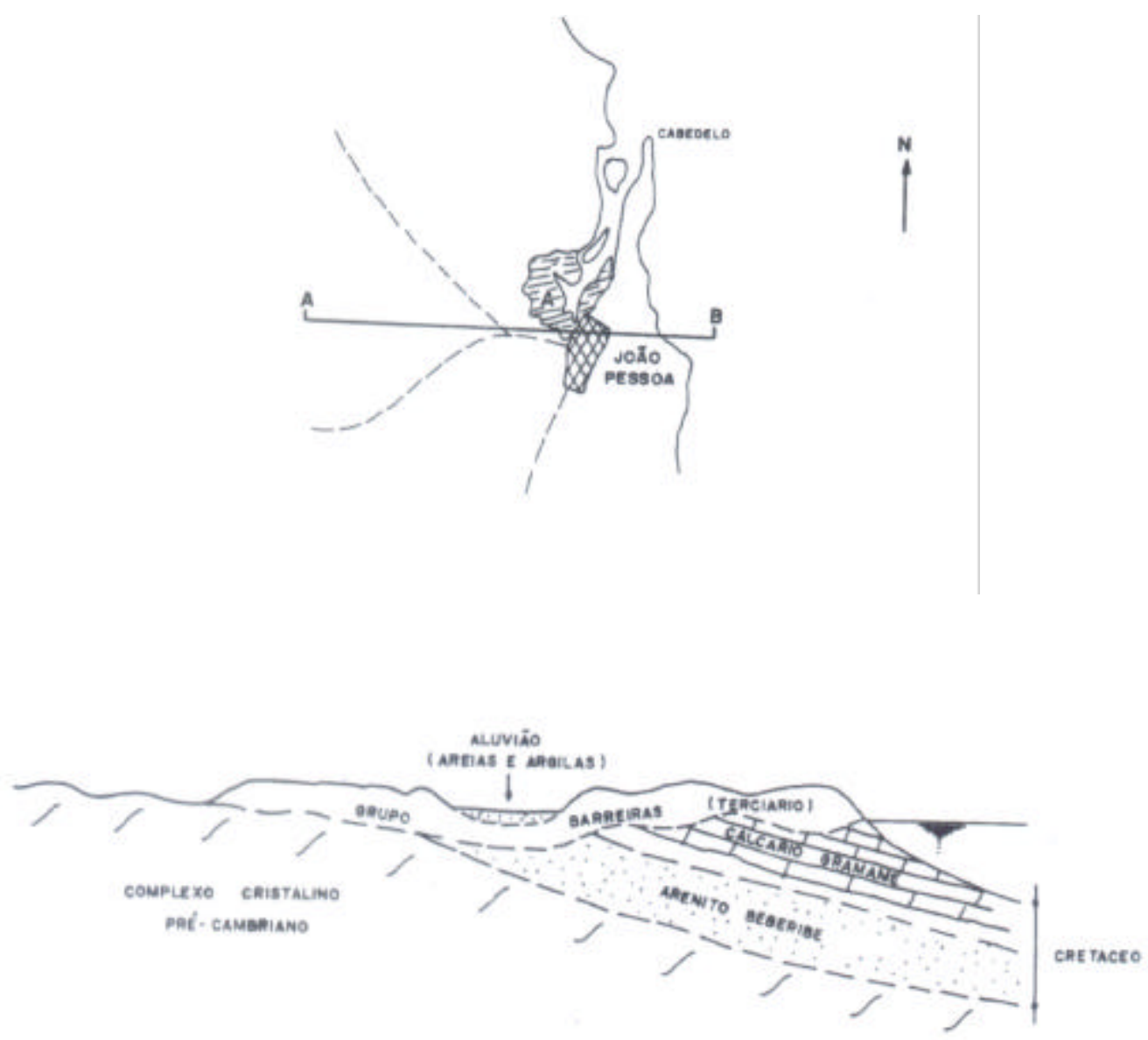

A

$\mathbf{B}$

Figura 3.1 - Perfil Geológico da cidade de João Pessoa (Gusmão Filho, 1982).

\subsection{Caracterização geotécnica}

As sondagens SPT foram realizadas pela empresa Concresolo - Consultoria em Concreto e Solos Ltda., tanto em solo natural como após a compactação, nos locais onde foram construídos os edifícios em estudo. Os perfis médios obtidos são exibidos nas Figuras 3.2 a 3.6.

As sondagens pós-compactação foram realizadas a $2 \mathrm{~m}$ do furo em solo matural e, ao mesmo tempo, em uma posição simétrica entre quatro estacas. Em alguns casos, elas só persistiram até cerca de $6 \mathrm{~m}$ de profundidade, quando se desejou apenas avaliar os efeitos do processo de melhoria. Devido a cortes no terreno para a execução de subsolos, observa-se que 
algumas delas iniciaram-se em profundidades mais baixas que as sondagens do terreno natural.

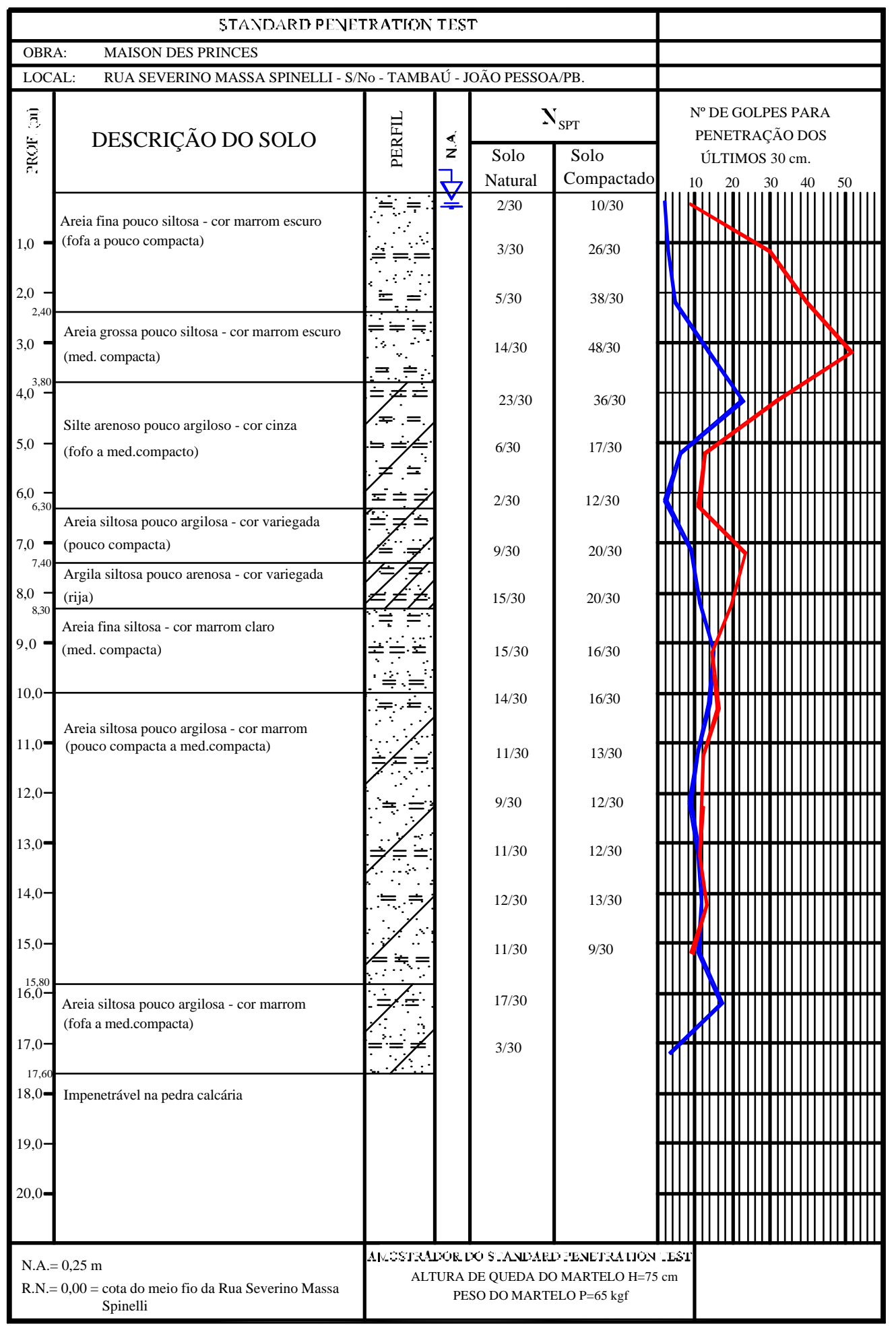

Figura 3.2 - Residencial Maison des Princes: perfil médio representativo das sondagens SPT realizadas em solo natural $\left(\mathrm{N}_{\mathrm{SPT}} \mathrm{S}\right.$ em linha azul) e em solo compactado $\left(\mathrm{N}_{\mathrm{SPT}} \mathrm{S}\right.$ linha vermelha) 


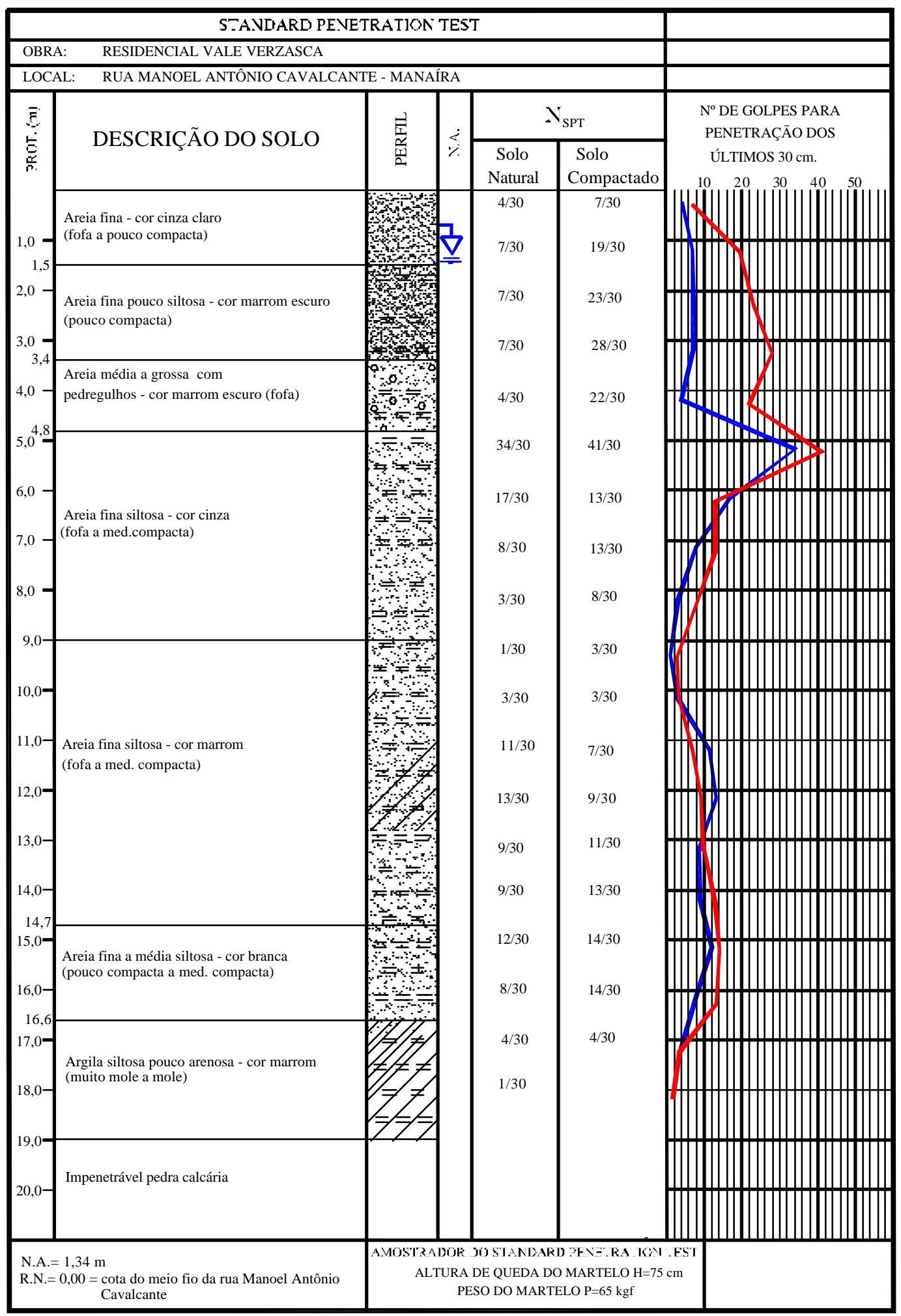

Figura 3.3 - Residencial Vale Verzasca: perfil médio representativo das sondagens SPT realizadas em solo natural ( $\mathrm{N}_{\mathrm{SPT}} \mathrm{S}$ em linha azul) e em solo compactado ( $\mathrm{N}_{\mathrm{SPT}} \mathrm{s}$ linha vermelha) 


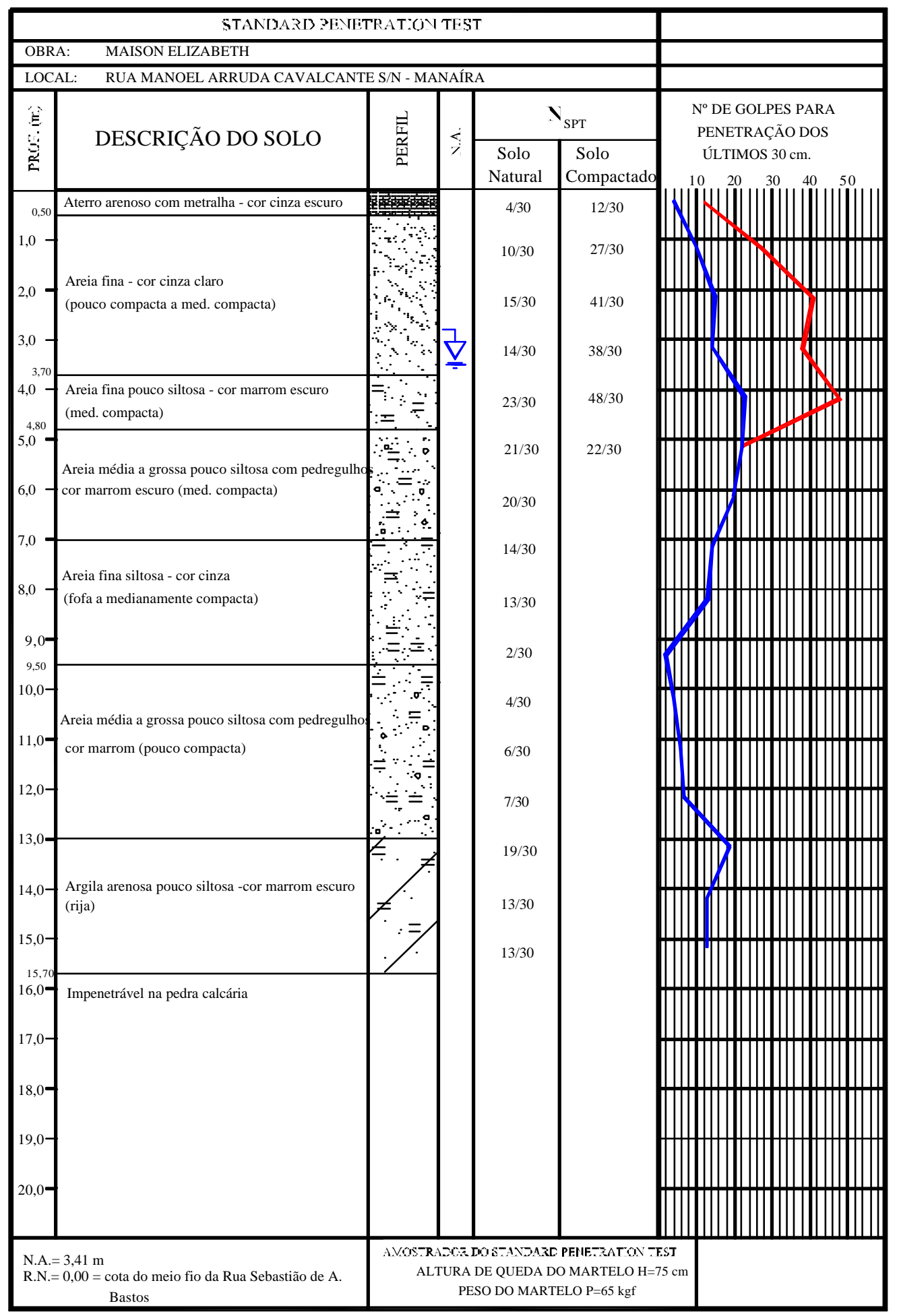

Figura 3.4 - Residencial Maison Elizabeth: perfil médio representativo das sondagens SPT realizadas em solo natural $\left(\mathrm{N}_{\mathrm{SPT}} \mathrm{S}\right.$ em linha azul) e em solo compactado $\left(\mathrm{N}_{\mathrm{SPT}} \mathrm{S}\right.$ linha vermelha) 


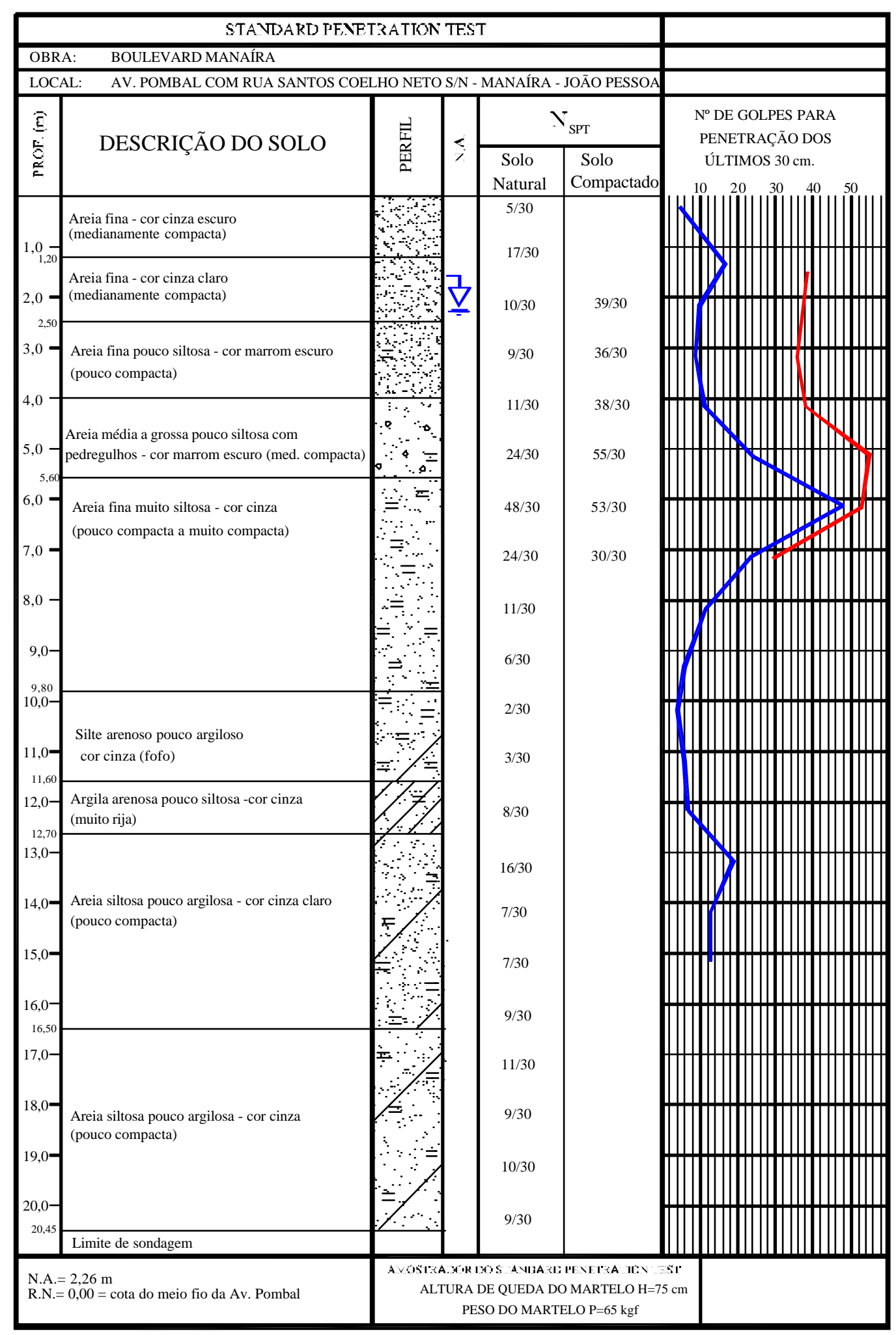

Figura 3.5 - Residencial Boulevard Manaíra: perfil médio representativo das sondage ns SPT realizadas em solo natural $\left(\mathrm{N}_{\mathrm{SPT}} \mathrm{S}\right.$ em linha azul) e em solo compactado

( $\mathrm{N}_{\mathrm{SPT}} \mathrm{s}$ linha vermelha) 


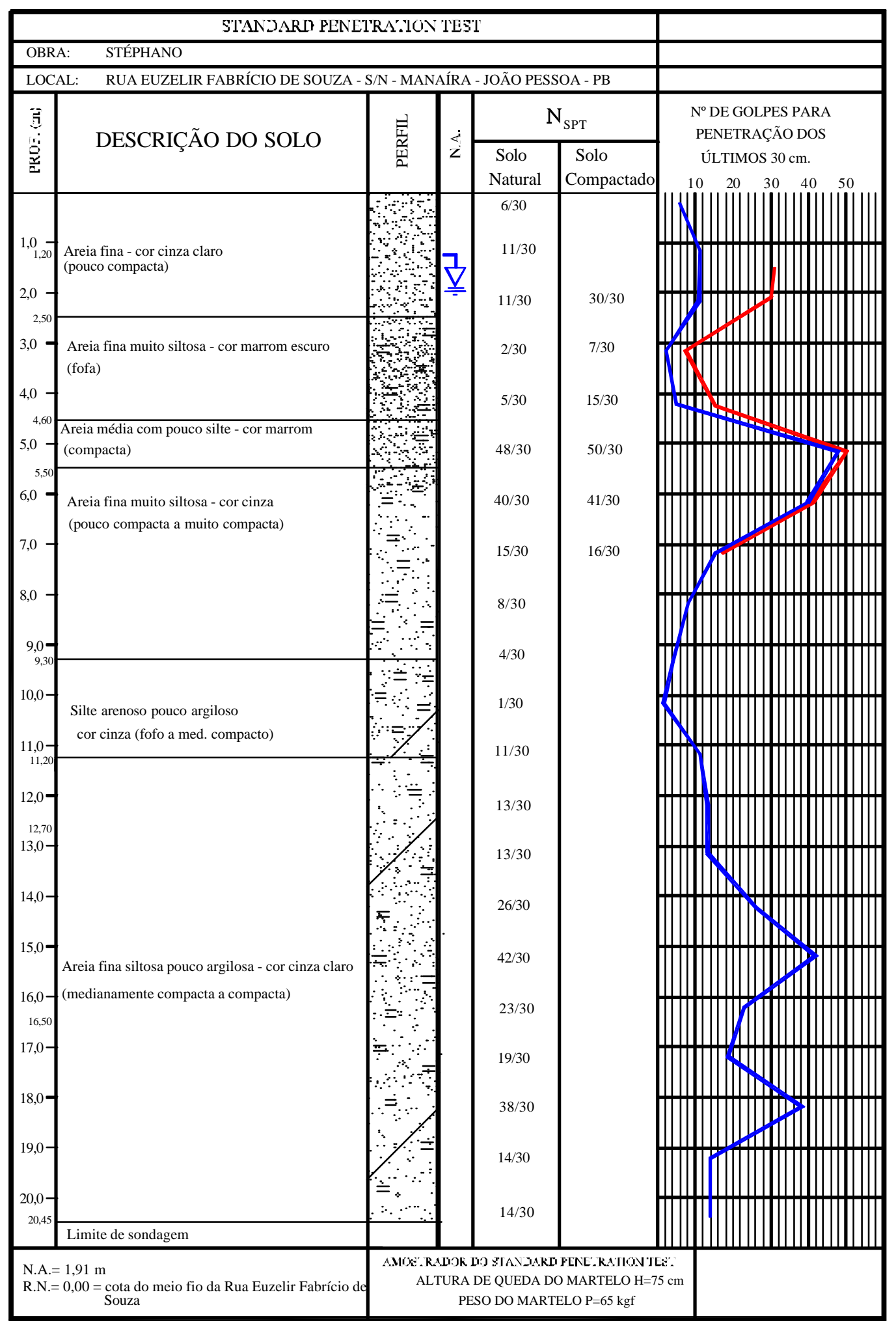

Figura 3.6 - Edifício Stéphano: perfil médio representativo das sondagens SPT realizadas em solo natural ( $\mathrm{N}_{\mathrm{SPT}} \mathrm{s}$ em linha azul) e em solo compactado ( $\mathrm{N}_{\mathrm{SPT}} \mathrm{s}$ linha vermelha) 


\section{Materiais e Métodos}

Foram monitorados os recalques de cinco edifícios sobre solo melhorado com estacas de compactação na cidade de João Pessoa - PB. Também foram feitas estimativas de recalque para esses edifícios.

\subsection{Monitoramento}

O monitoramento dos edifícios foi feito por equipes de topógrafos contratadas pela empresa Copesolo - Estacas e Fundações Ltda, que cedeu os dados obtidos para a realização deste trabalho.

Foram instalados pinos em três pilares de cada prédio, e as leituras foram feitas com um nível automático. O referencial de nível adotado foi o meio-fio das ruas dos edifícios. 
De fevereiro de 2001 a fevereiro de 2004, monitoraram-se três dos cinco edifícios, com medições que começaram alguns meses após o início da construção dos mesmos. Foram feitas leituras até o fim das construções dos três, e um pouco além em dois deles.

Desde setembro e outubro de 2004, os outros dois dos cinco edifícios vêm sendo monitorados, a partir do início de suas construções.

\subsubsection{E difícios monitorados}

Os cinco edifícios monitorados são:

$\rightarrow$ Maison des Princes, com 30 pavimentos;

$\rightarrow$ Vale Verzasca, com 26 pavimentos;

$\rightarrow$ Maison Elizabeth, com 21 pavimentos;

$\rightarrow$ Boulevard Manaíra, com 18 pavimentos;

$\rightarrow$ Edifício Stéphano, com 17 pavimentos.

As Tabelas 4.1 e 4.2 mostram o período de monitoramento de cada edifício, assim como a fase estrutural de cada obra no início das campanhas de leituras. Em João Pessoa, as edificações residenciais costumam ter estrutura de concreto armado convencional e fechamento com alvenaria de tijolos cerâmicos, caso dos edifícios envolvidos na pesquisa. Também é comum, durante a construção, passarem por uma fase inicial em que é feita toda a parte estrutural do edifício. Nesta fase, são concretados, para cada pavimento, as lajes, pilares, e, geralmente, executada meia alvenaria. Em fase posterior a estrutural são executados os revestimentos externo, interno e os pisos.

As Figuras 4.1 a 4.5 exibem os edifícios monitorados. 
Tabela 4.1 - Período de monitoramento dos edifícios e fase estrutural dos edifícios no início das medições

\begin{tabular}{|c|c|c|c|}
\hline Edifício & $\begin{array}{c}\text { Início do } \\
\text { monitotamento }\end{array}$ & $\begin{array}{l}\text { Fase estrutural da } \\
\text { construção }\end{array}$ & $\begin{array}{c}\text { Fim do } \\
\text { monitoramento }\end{array}$ \\
\hline Maison des Princes & \multirow{3}{*}{ Fevereiro de 2001} & $\begin{array}{l}20 \text { pavimentos } \\
\text { concretados c } 1 / 2 \\
\text { alvenaria }\end{array}$ & \multirow{3}{*}{ Fevereiro de 2004} \\
\hline Vale Verzasca & & $\begin{array}{l}18 \text { pavimentos } \\
\text { concretados c } 1 / 2 \\
\text { alvenaria }\end{array}$ & \\
\hline Maison Elizabeth & & $\begin{array}{l}10 \text { pavimentos } \\
\text { concretados c } 1 / 2 \\
\text { alvenaria }\end{array}$ & \\
\hline Boulevard Manaíra & Outubro de 2004 & $\begin{array}{l}2 \text { pavimentos } \\
\text { concretados }\end{array}$ & - \\
\hline Stéphano & Setembro de 2004 & $\begin{array}{l}1 \text { pavimento } \\
\text { concretado }\end{array}$ & - \\
\hline
\end{tabular}

Tabela 4.2 - Período de monitoramento de cada obra

\begin{tabular}{ccccc}
\hline Edifício & $\begin{array}{c}\text { Duração da } \\
\text { construção }\end{array}$ & $\begin{array}{c}\text { Início do } \\
\text { monitoramento }\end{array}$ & $\begin{array}{c}\text { Meses monitorados } \\
\text { durante a } \\
\text { construção }\end{array}$ & $\begin{array}{c}\text { Meses } \\
\text { monitorados após } \\
\text { a construção }\end{array}$ \\
\hline $\begin{array}{c}\text { Maison des } \\
\text { Princes }\end{array}$ & 44 meses & $\begin{array}{c}10^{\circ} \text { mês de } \\
\text { construção }\end{array}$ & 34 & 2 \\
\hline Vale Verzasca & 37 meses & $\begin{array}{c}9^{\circ} \text { mês de } \\
\text { construção }\end{array}$ & 28 & 8 \\
\hline Maison Elizabeth & 41 meses & $\begin{array}{c}5^{\circ} \text { mês de } \\
\text { construção }\end{array}$ & 36 & - \\
\hline Boulevard & - & $\begin{array}{c}1^{\circ} \text { mês de } \\
\text { construção }\end{array}$ & 8 & - \\
\hline Manaíra & - & $\begin{array}{c}1^{\circ} \text { mês de } \\
\text { construção }\end{array}$ & 9 & - \\
\hline
\end{tabular}




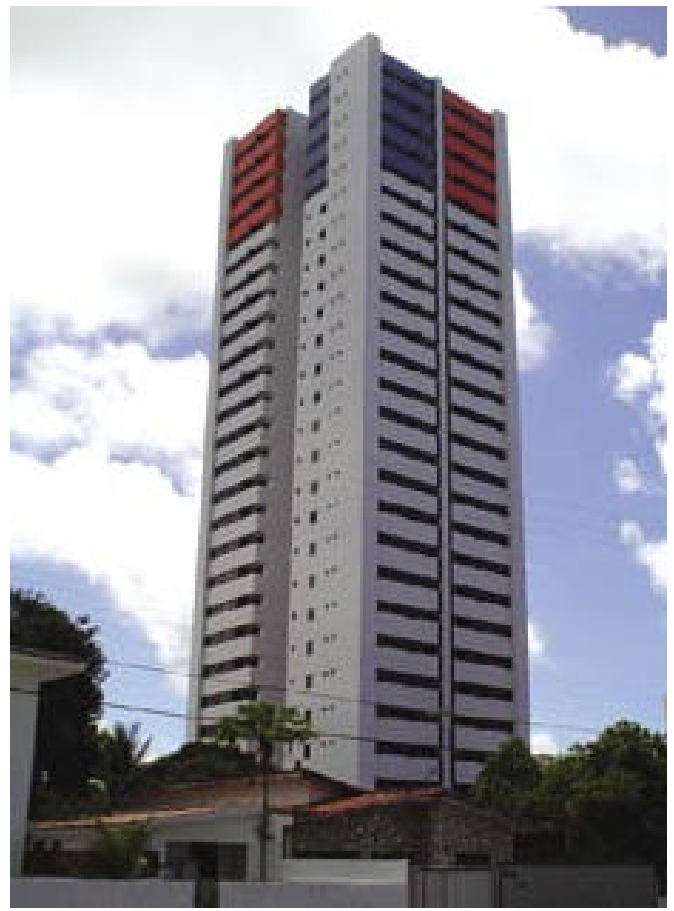

Figura 4.1 - Residencial Maison des Princes

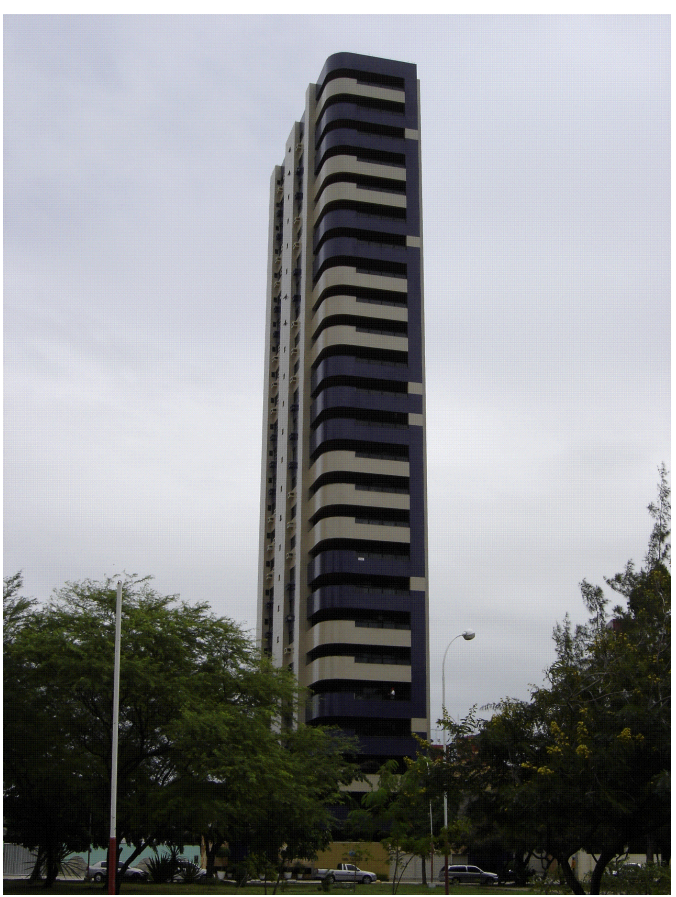

Figura 4.2 - Residencial Vale Verzasca 


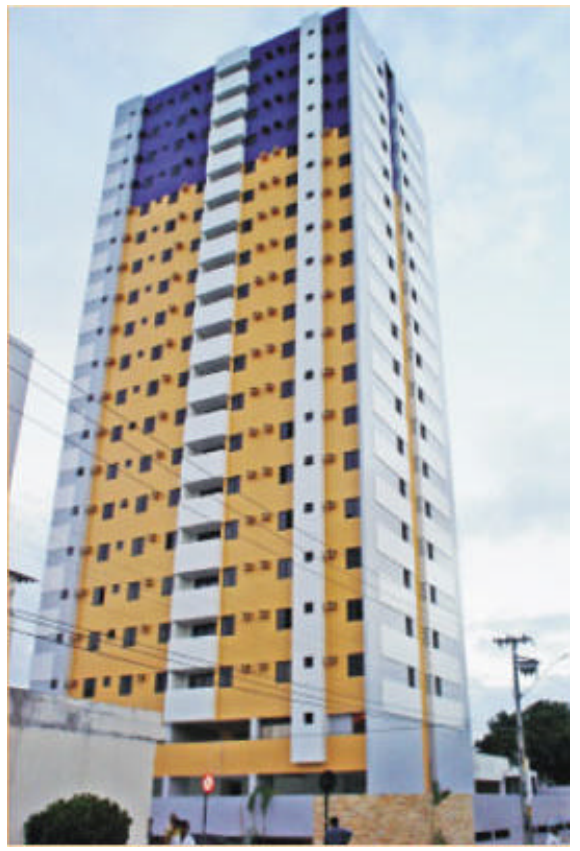

Figura 4.3 - Residencial Maison Elizabeth

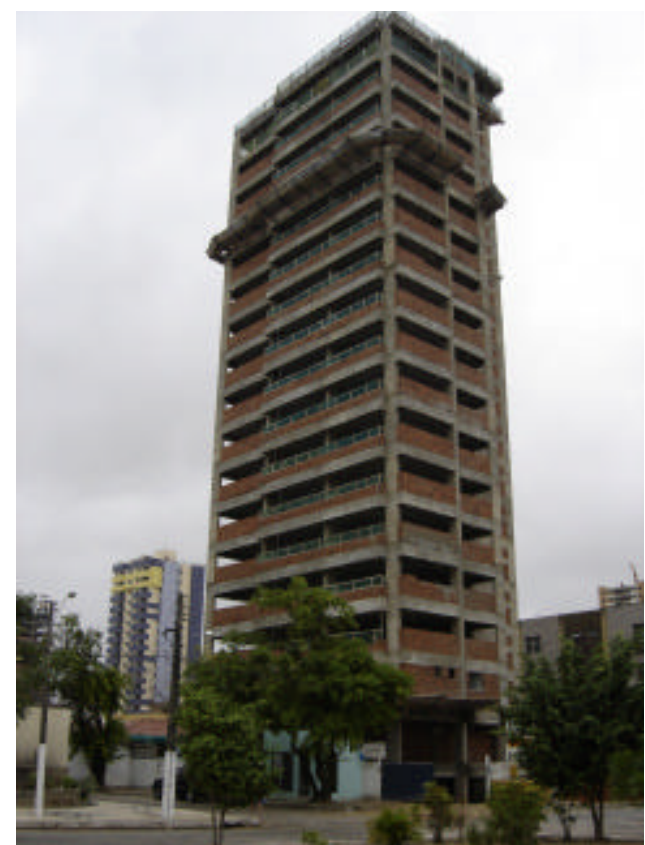

Figura 4.4 - Edifício Boulevard manaíra 


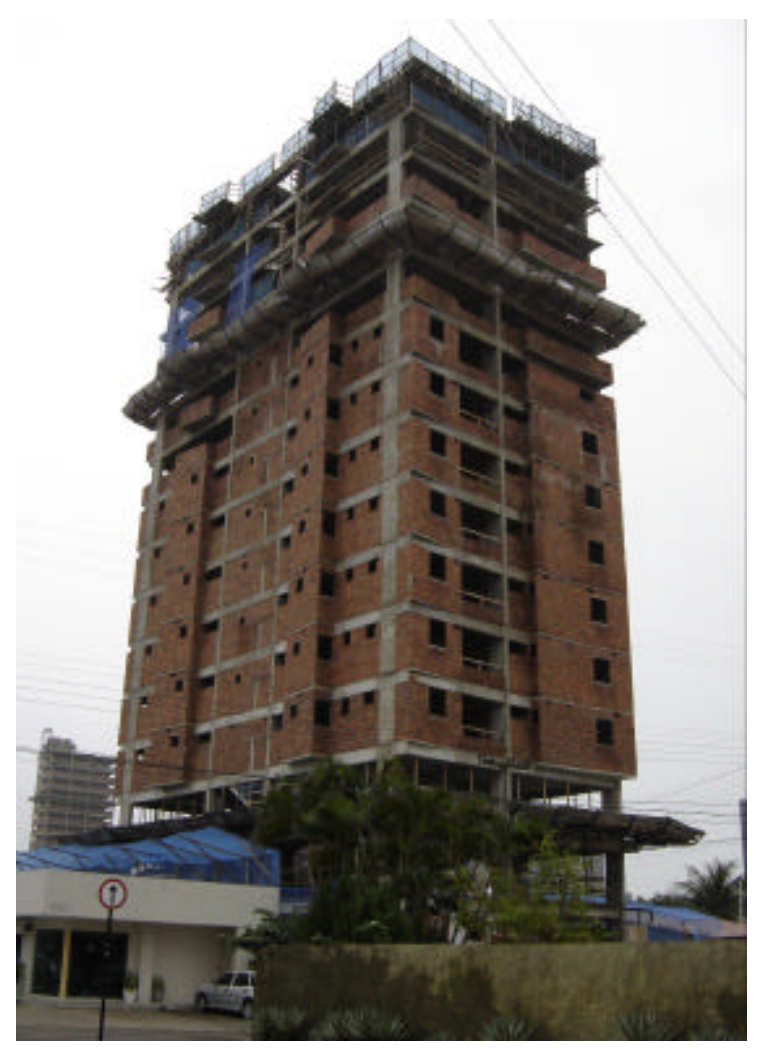

Figura 4.5 - Edifício Stéphano

O Anexo A mostra a tabela de cargas de projeto atuantes nas sapatas dos cinco edifícios, de acordo com os projetos de fundações elaborados pela empresa Copesolo Estacas e Fundações Ltda. As Figuras 4.6 a 4.10 exibem as plantas de forma das sapatas e os esquemas de locação das estacas de compactação dos mesmos edifícios. Em todos os casos, o diâmetro das estacas foi de $30 \mathrm{~cm}$ e a tensão admissível adotada no projeto das fundações por sapatas de 0,5 MPa. A distância de eixo-a-eixo das estacas variou de 80 a $110 \mathrm{~cm}$, com disposições que extrapolaram a região sob as sapatas até quase toda a área de projeção do prédio. A Tabela 4.3 contém os dados dos edifícios referentes ao material constituinte, espaçamento e profundidade das estacas. 


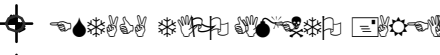

- $\Leftrightarrow 20$

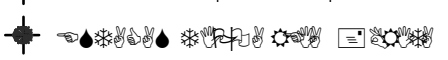
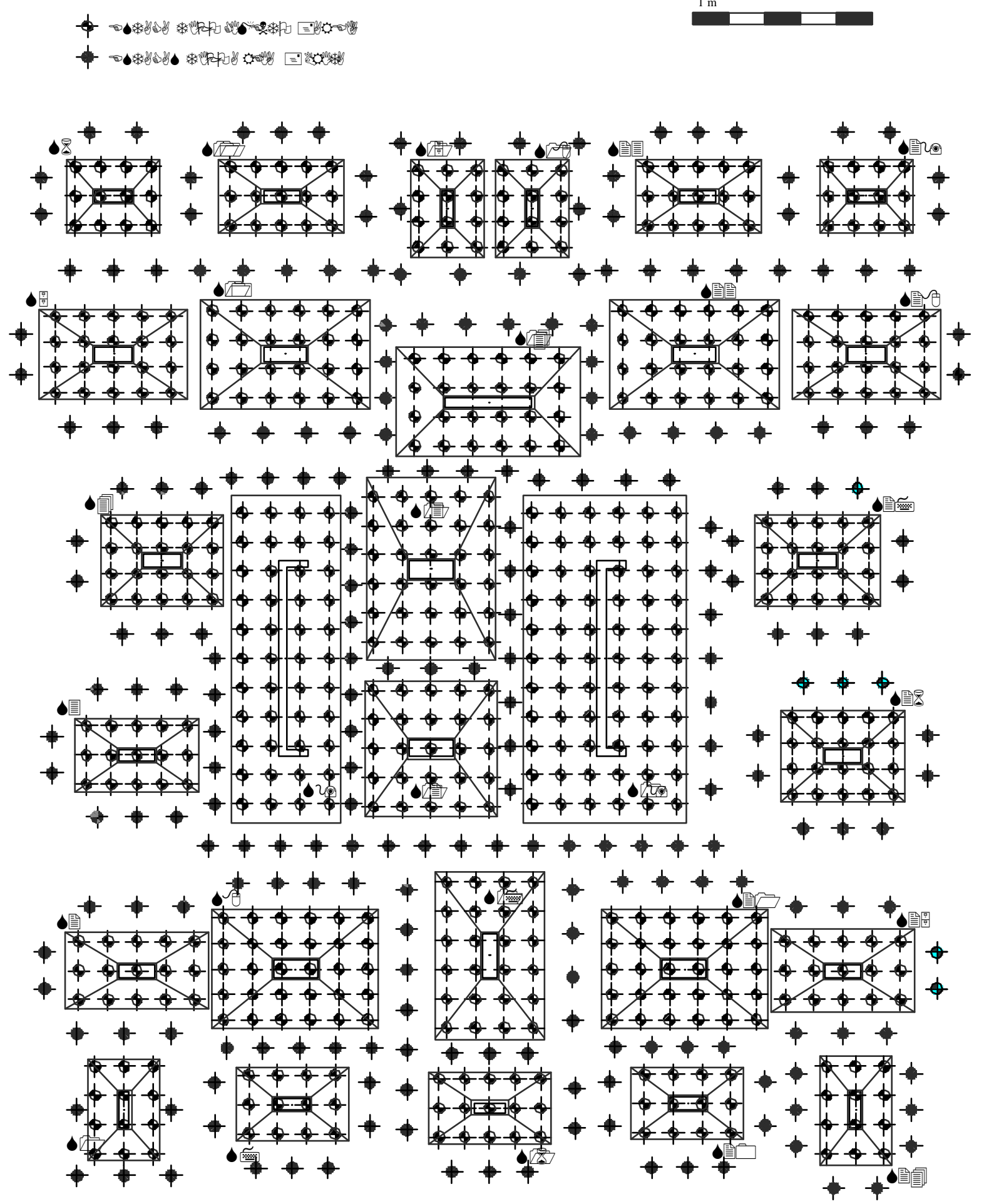

Figura 4.6 - Maison des Princes: planta de forma das sapatas e esquema de locação das estacas de compactação 


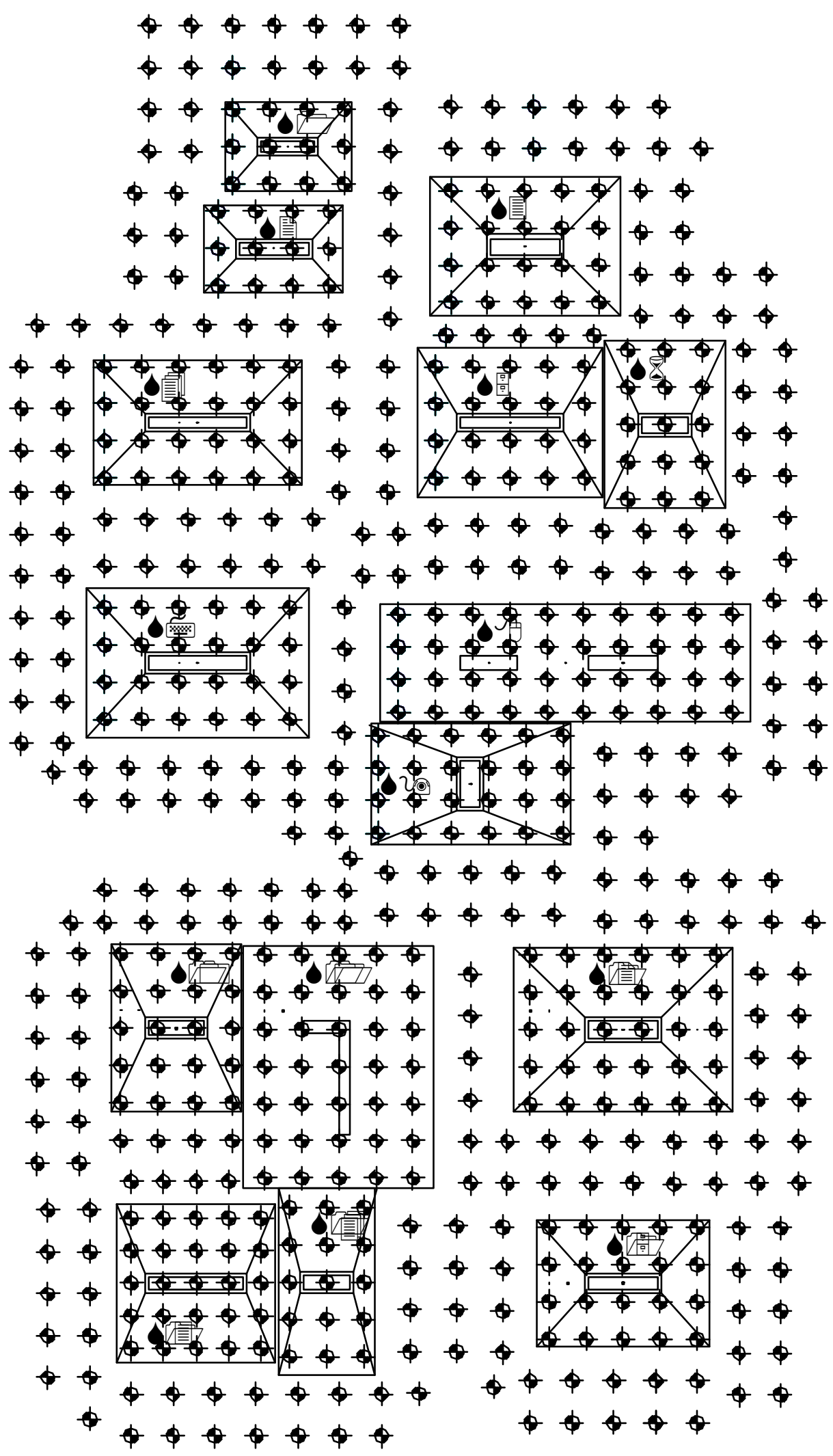

Figura 4.7 - Vale Verzasca:planta de forma das sapatas e esquema de locação das estacas de compactação 


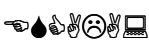

$1 \mathrm{~m}$

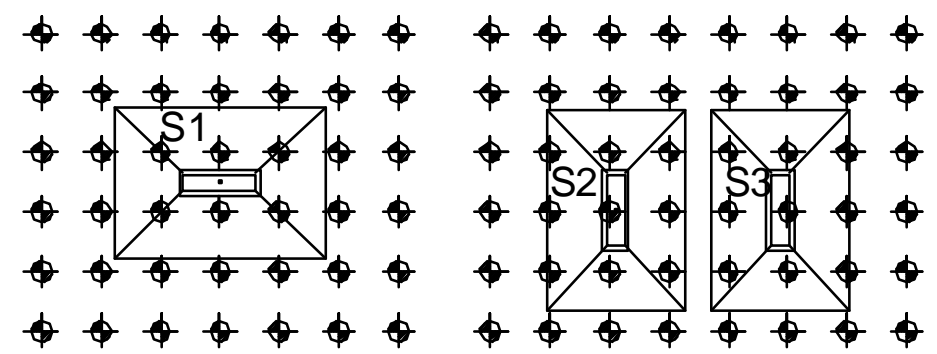

$+\phi \phi \phi \phi$

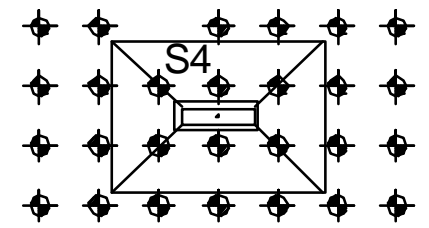

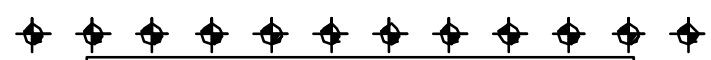

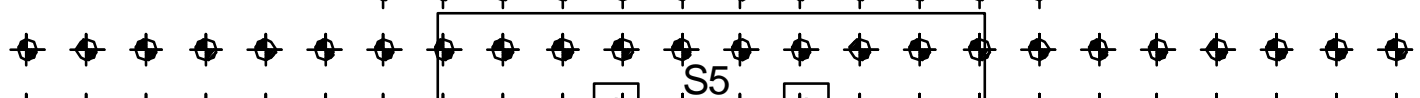

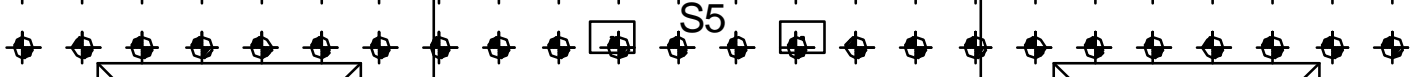

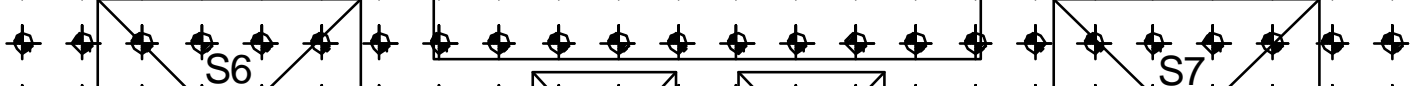

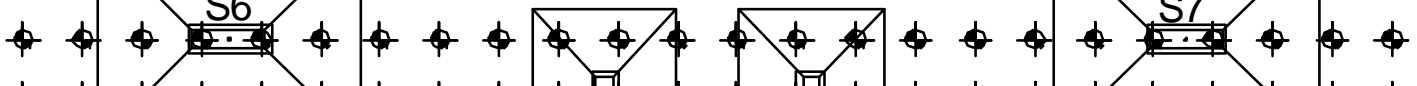

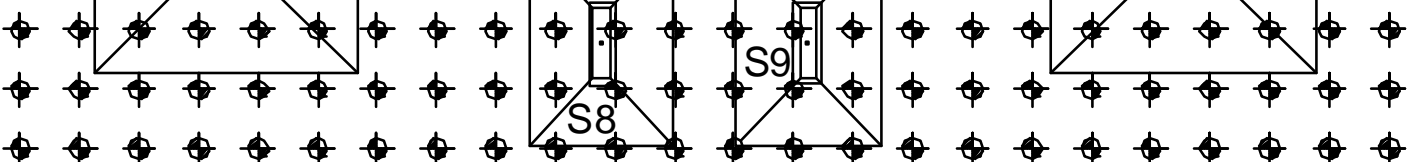

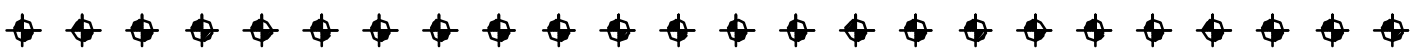

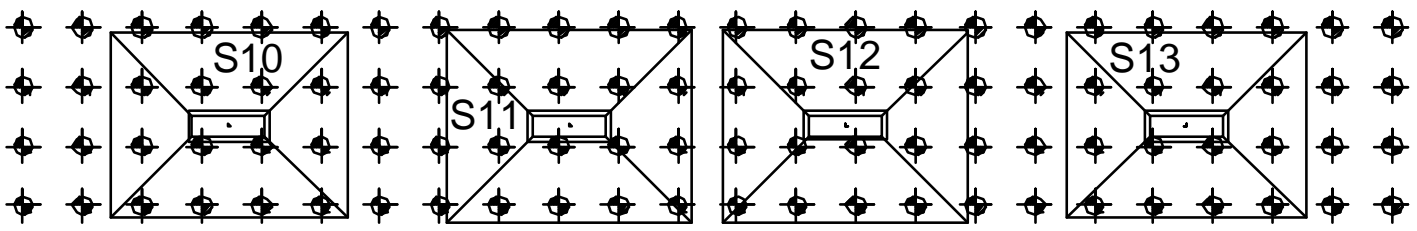

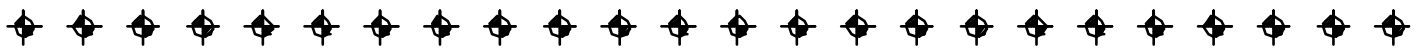

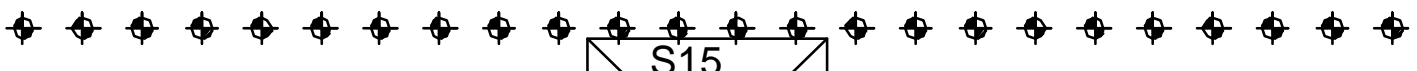

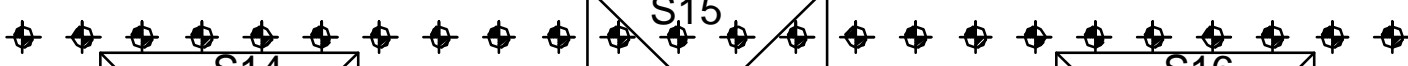

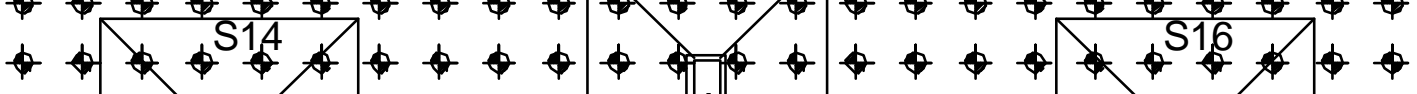

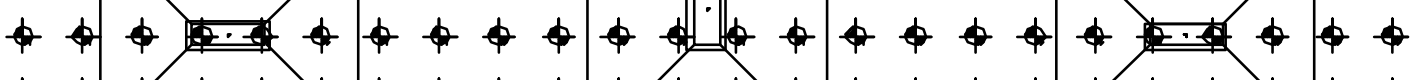

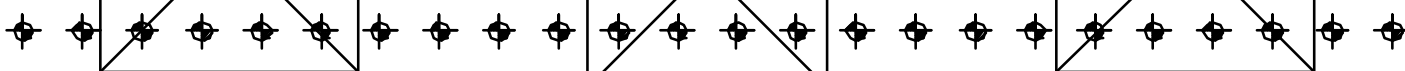

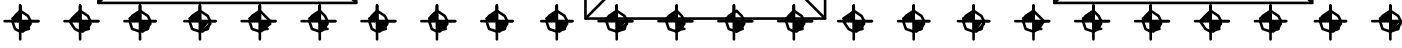

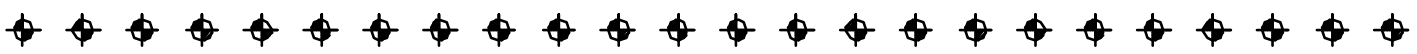

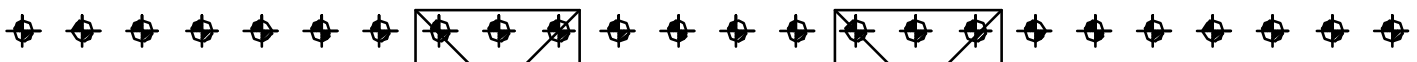

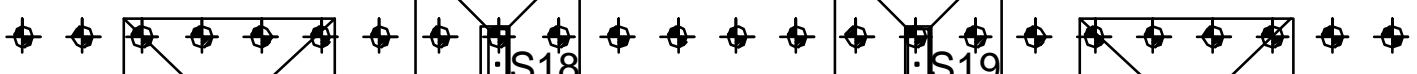

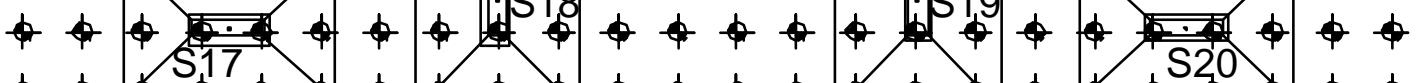

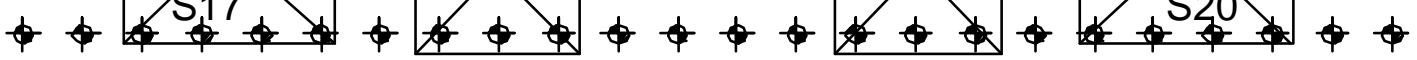

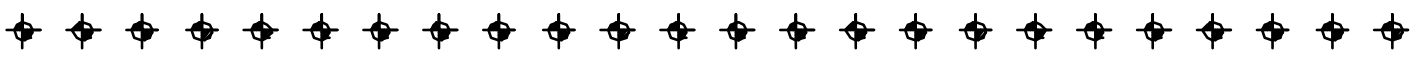

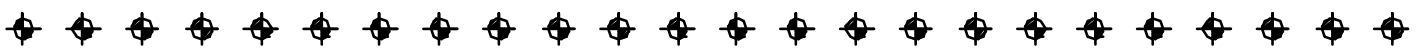

Figura 4.8 - Maison Elizabeth: planta de forma das sapatas e esquema de locação das estacas de compactação 
(4)

$1 \mathrm{~m}$

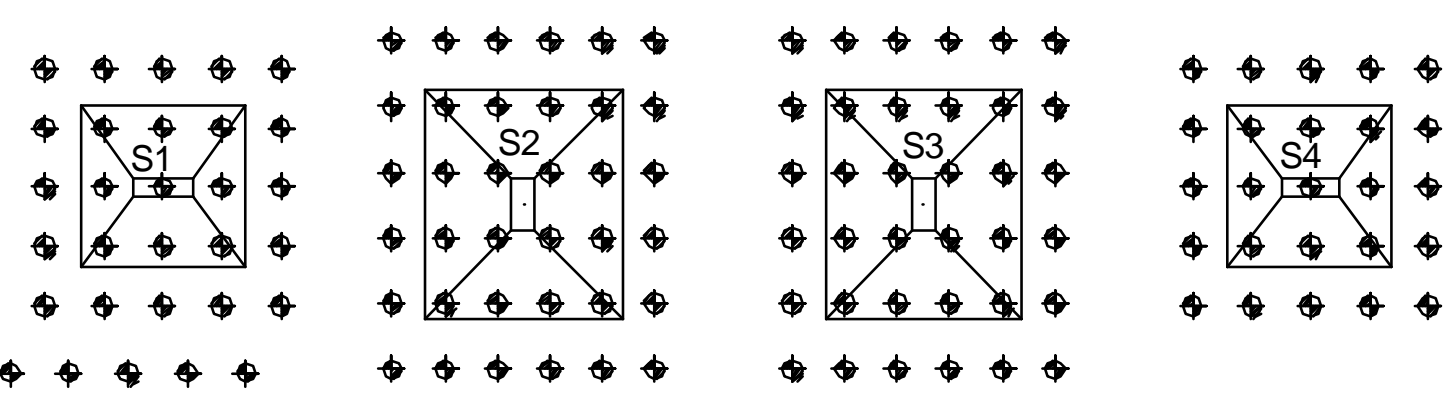

$+\infty 0_{0}^{\infty}$

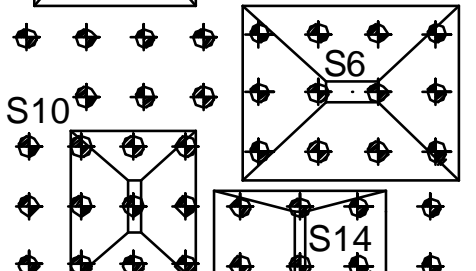

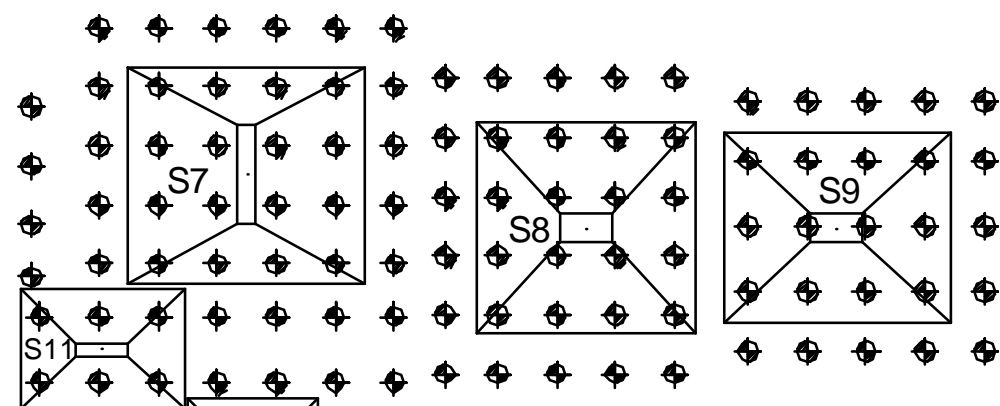

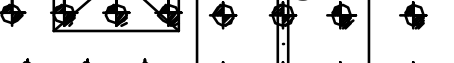

$-0+0$

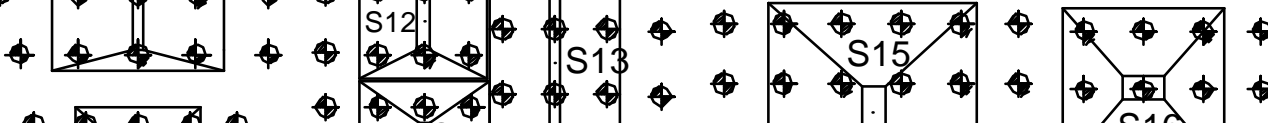

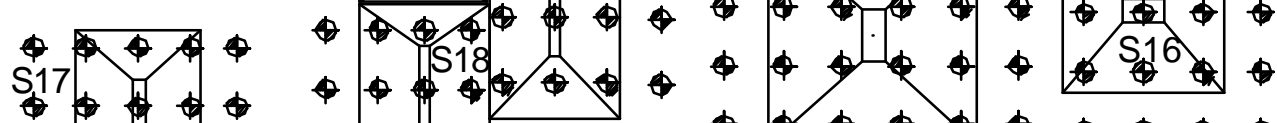

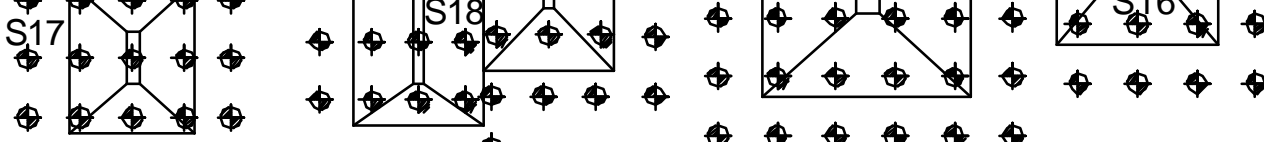

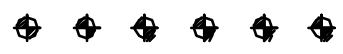

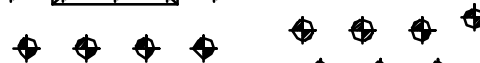

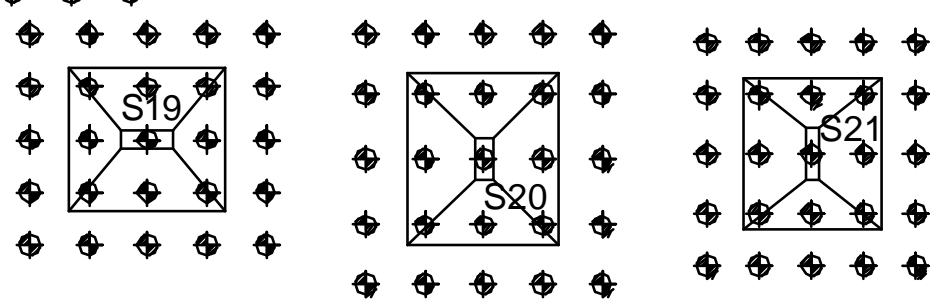

Figura 4.9 - Boulevard Manaíra: planta de forma das sapatas e esquema de locação das estacas de compactação 
4

$11 \mathrm{~m}$

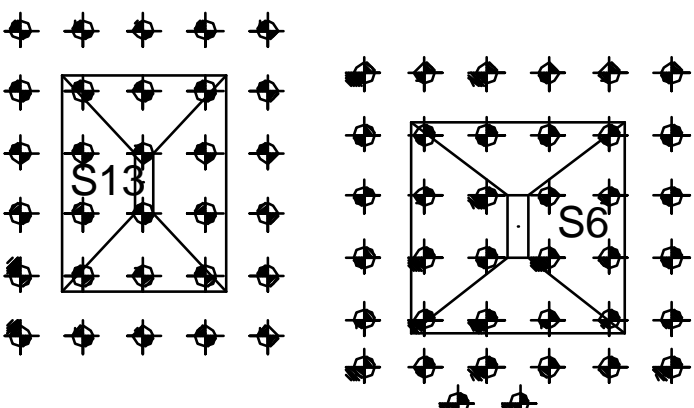

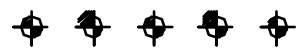

$4+4$

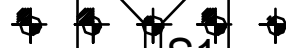

$\phi \phi \phi$

$+4$

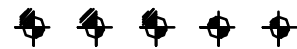

$\phi \phi \phi$

$\phi \phi \phi$

$\phi \phi \phi \phi$

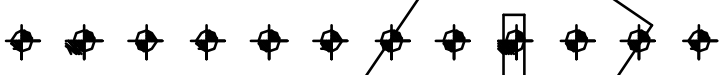

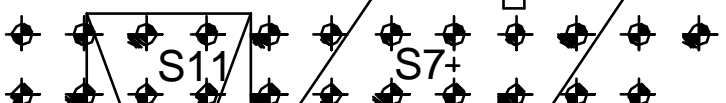

- 52 क

$-\phi$

$\rightarrow \phi$

$\leftrightarrow \rightarrow \phi$

$\phi \phi \phi$

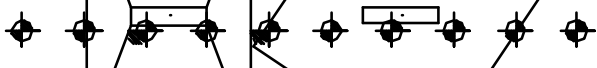

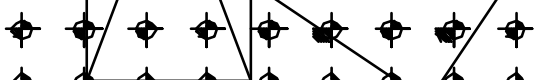

$\phi \phi \phi$

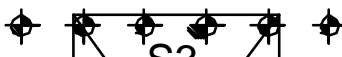

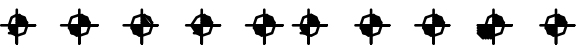

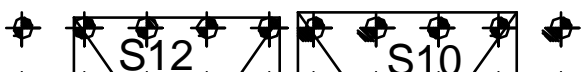

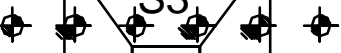

$\phi \rightarrow \phi$

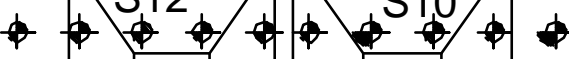

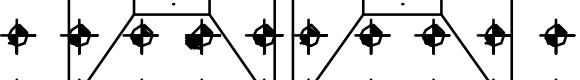

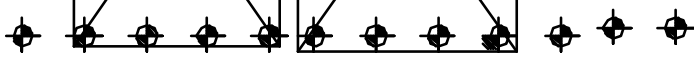

$+4$

$\phi \phi \phi$

$\phi \phi \phi \phi$
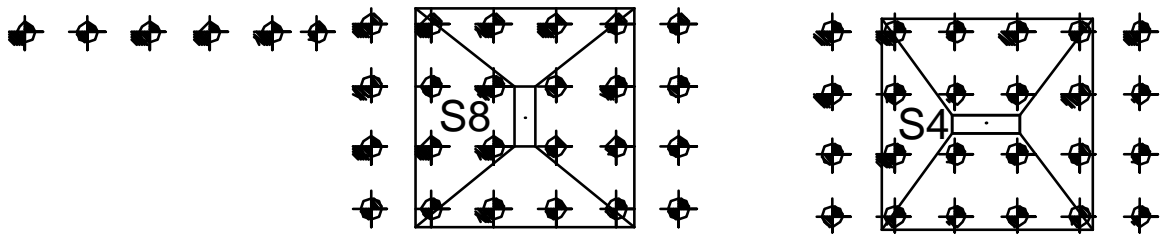

$\phi$

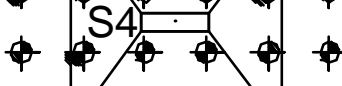

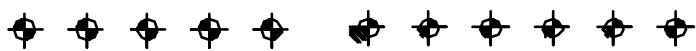

$\phi \rightarrow \infty$

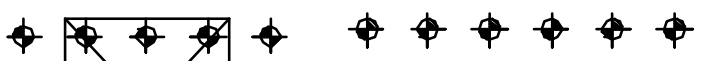

$\phi+\phi$

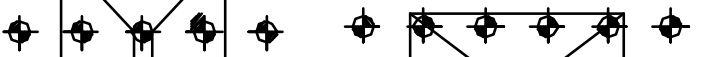

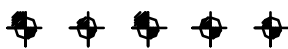
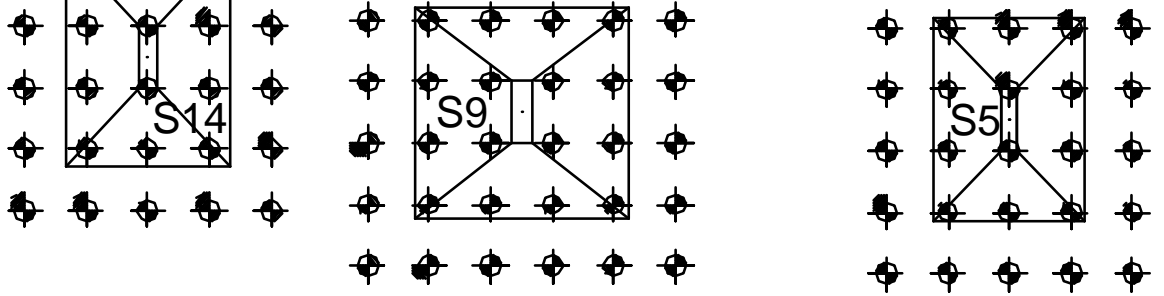

Figura 4.10 - Stéphano: planta de forma das sapatas e esquema de locação das estacas de compactação 
Tabela 4.3 - Dados das estacas de cada edifício

\begin{tabular}{cccc}
\hline Edifício & Materiais da estaca & Espaçamento & Cota de apoio da estaca \\
\hline Maison des Princes & $\begin{array}{c}\text { Areia + cimento } \\
\text { Areia + brita }\end{array}$ & $\begin{array}{c}80 \mathrm{~cm} \\
110 \mathrm{~cm}\end{array}$ & $\begin{array}{c}5 \mathrm{~m} \\
3,5 \mathrm{~m}\end{array}$ \\
\hline Vale Verzasca & Areia + cimento & $90 \mathrm{~cm}$ & $3,5 \mathrm{~m}$ \\
\hline Maison Elizabeth & Areia + cimento & $90 \mathrm{~cm}$ & $3,0 \mathrm{~m}$ \\
\hline Boulevard Manaíra & Areia + brita & $80-100 \mathrm{~cm}$ & $3,5 \mathrm{~m}$ \\
\hline Stéphano & Areia + brita & $90 \mathrm{~cm}$ & $3,5 \mathrm{~m}$ \\
\hline
\end{tabular}

O traço em volume das estacas de areia e cimento foi de 15:1 e das de areia e brita, 4:1. Não se levou em conta o encurtamento dos pilares monitorados. Consideraram-se os recalques medidos como sendo o das sapatas, assim como estas foram consideradas rígidas. A Tabela 4.4 indica as sapatas cujos pilares foram monitorados.

Tabela 4.4 - Sapatas cujos pilares foram monitorados em cada edifício

\begin{tabular}{cccc}
\hline Edifício & \multicolumn{3}{c}{ Sapatas cujos pilares foram monitorados } \\
\hline M. Princes & S6 & S8 & S13 \\
\hline Vale Verzasca & S2 & S3 & S14 \\
\hline M. Elizabeth & S11 & S17 & S20 \\
\hline Boulevard Manaíra & S1 & S7 & S21 \\
\hline Stéphano & S5 & S7 & S13
\end{tabular}




\subsection{Estimativas}

Foram estimados os recalques totais de todas as sapatas dos edifícios para as situações de solo natural e solo compactado. Para isso, utilizourse o método Aoki \& Lopes (1975), que permite a consideração da influência de todas as sapatas da fundação, nas estimativas de recalque de cada uma delas.

O método foi aplicado por meio de um programa computacional desenvolvido em linguagem Fortran por Reis (2000). Como dados de entrada, foram fornecidos:

$\rightarrow$ Carga de projeto de cada sapata, assim como as dimensões, coordenadas e cotas de assentamento das mesmas. As sapatas dos edifícios Maison des Princes, Vale Verzasca e Maison Elizabeth foram assentes a $1 \mathrm{~m}$ de profundidade. As do Boulevard Manaíra e Stéphano, a 1,5 m.

$\rightarrow$ Em relação ao solo, forneceram-se os números de camadas componentes de cada perfil geotécnico e suas características como espessura, profundidade, módulo de deformabilidade $\left(\mathrm{E}_{0}\right)$ e coeficiente de Poisson (n). Tais informações foram obtidas a partir dos perfis médios dos solos, mostrados no Capítulo 3. O solo compactado foi admitido homogêneo, sem a consideração das estacas.

Os valores do módulo de deformabilidade $\left(\mathrm{E}_{0}\right)$ de cada camada foram estimados a partir da correlação com o índice de resistência à penetração $\left(\mathrm{N}_{\mathrm{SPT}}\right)$ das sondagens $\mathrm{SPT}$ apresentada por Teixeira \& Godoy (1996). Os valores utilizados para os coeficientes K e de Poisson e para o fator $\alpha$ foram os apresentados pelos mesmos autores. Este último fator $(\alpha)$ teve os seguintes valores adotados: areia siltosa $-3,5$, silte arenoso $-4,5$, silte argiloso $-5,5$ e argila siltosa $-6,5$.

Calculou-se o $\mathrm{N}_{\mathrm{SPT}}$ médio de cada camada por meio de média ponderada cujos pesos eram a espessura contida em cada metro com seus valores de $\mathrm{N}_{\mathrm{SPT}}$. 
Não se levou em conta a interação estrutura-solo e considerou-se o efeito de grupo. $\mathrm{O}$ recalque resultante deste procedimento foi admitido como total ou estabilizado. Com os valores obtidos, foram feitas curvas de isorecalque das situações de solo compactado e natural para os cinco edifícios, utilizando-se o programa Surfer 7.0. 


\section{$\underline{\text { Resultados }}$}

\subsection{Monitoramento}

As curvas tempo $\mathrm{x}$ recalque das sapatas cujos pilares foram monitorados são apresentadas nas Figuras 5.1 a 5.5.

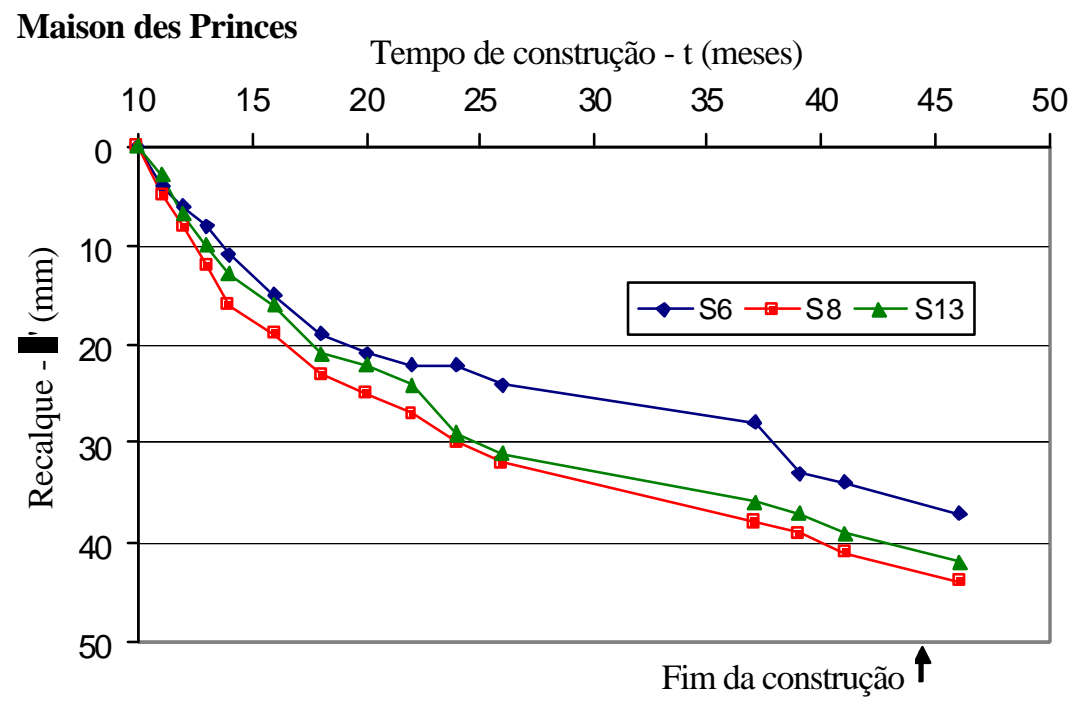

Figura 5.1 - Maison des Princes: curvas tempo x recalque de três sapatas 


\section{Vale Verzasca}

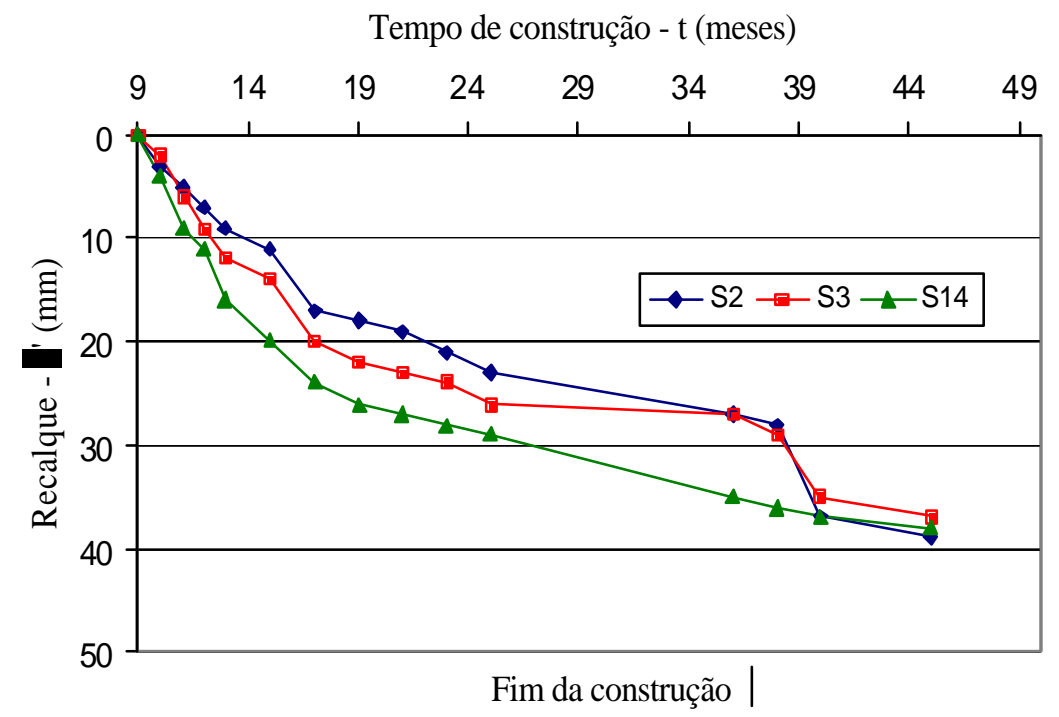

Figura 5.2 - Vale Verzasca: curvas tempo x recalque de três sapatas

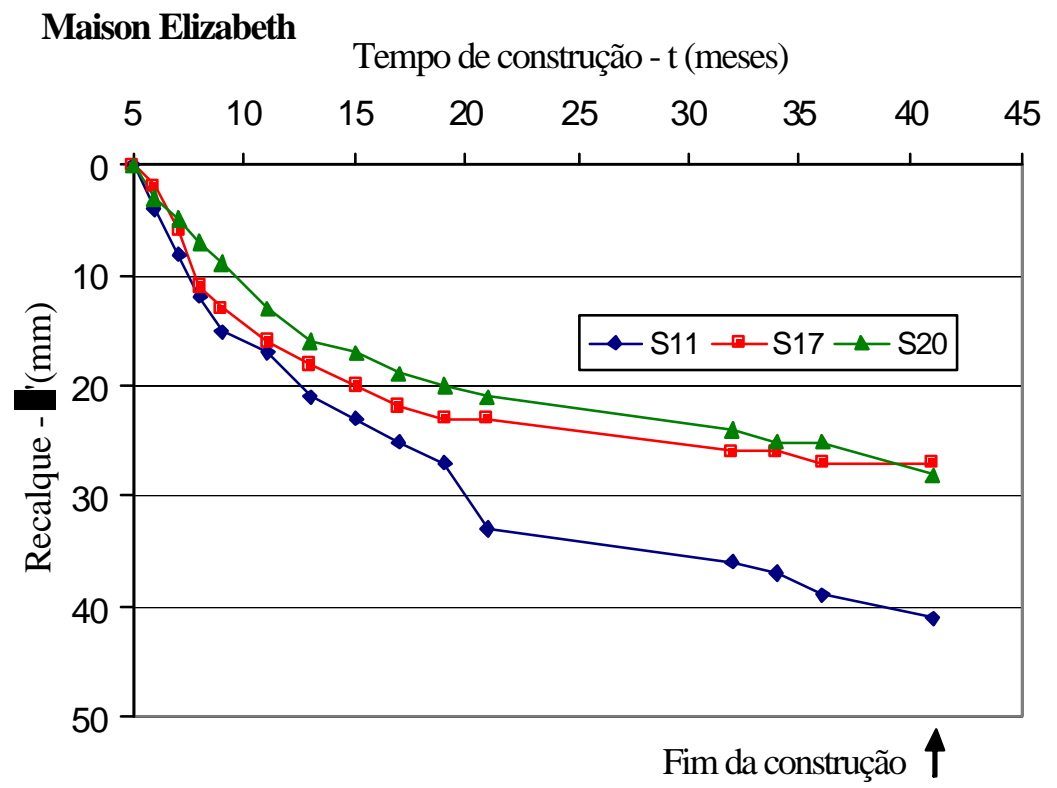

Figura 5.3 - Maison Elizabeth: curvas tempo x recalque de três sapatas 


\section{Boulevard Manaíra}

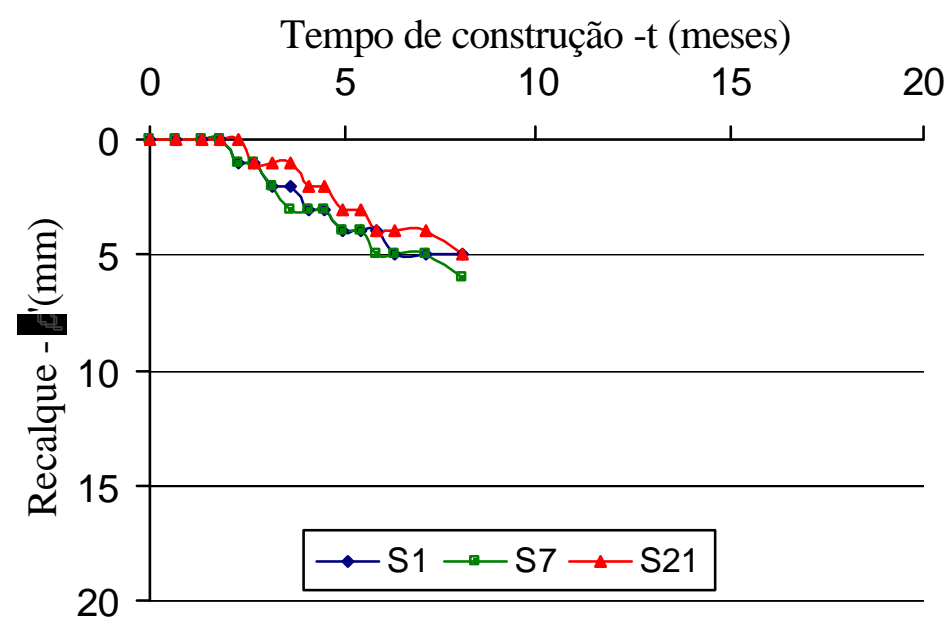

Figura 5.4 - Boulevard Manaíra: curvas tempo x recalque de três sapatas

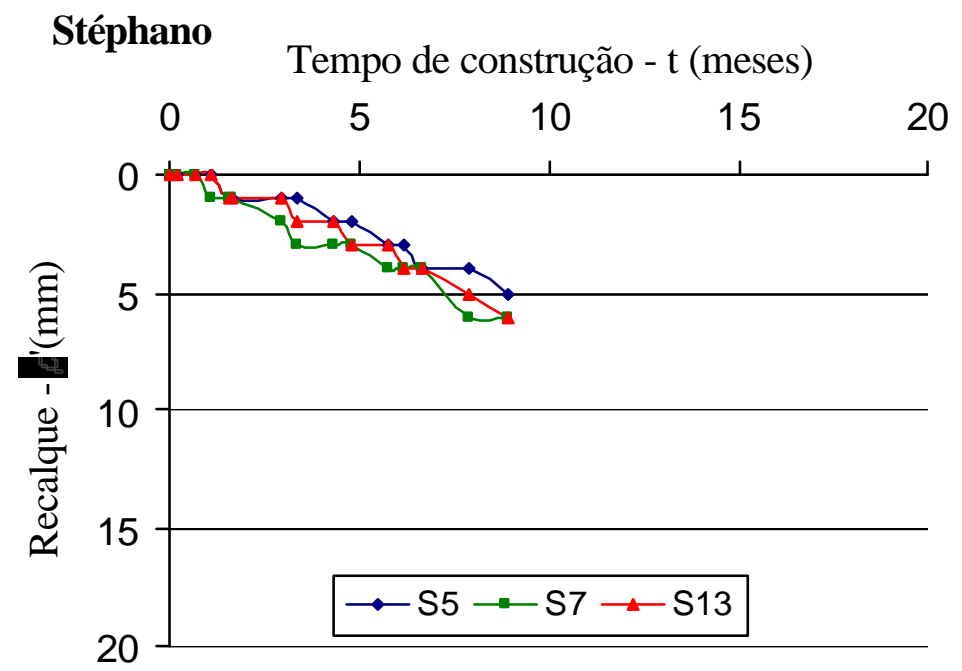

Figura 5.5 - Stéphano: curvas tempo x recalque de três sapatas

\subsection{Estimativas}

\subsubsection{Módulo de deformabilidade}

As Figuras 5.6 a 5.10 mostram a variação com a profundidade dos valores do módulo de deformabilidade inicial $\left(\mathrm{E}_{0}\right)$, adotados para as camadas do solo natural e do solo compactado sob os edifícios monitorados. 


\section{Maison des Princes}

Módulo de deformabilidade - Eo (MPa)

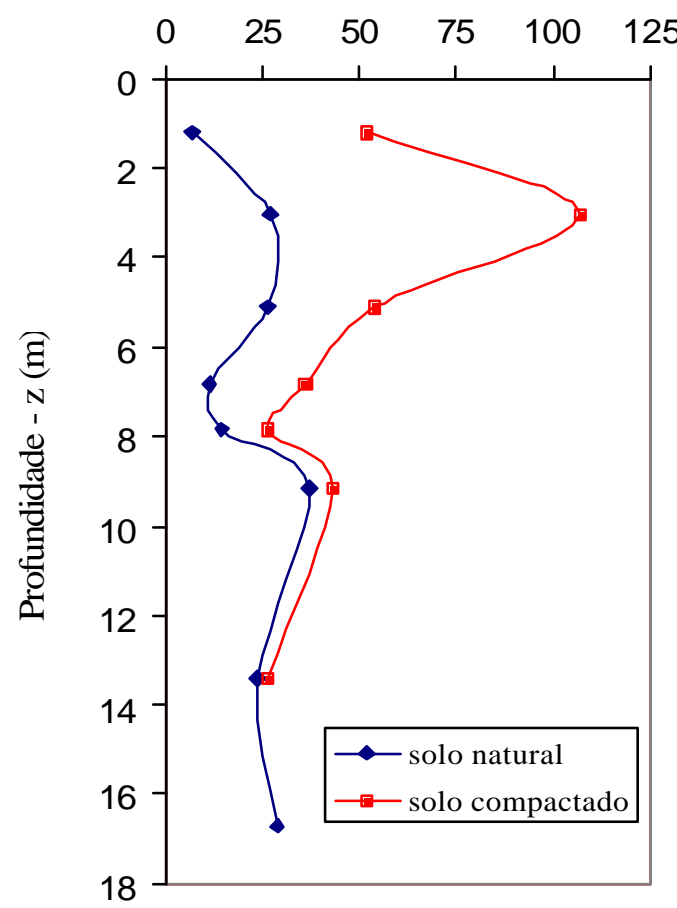

Figura 5.6 - Maison des Princes: Gráfico de $\mathrm{E}_{0}$ x z para solo natural e compactado

\section{Vale Verzasca}

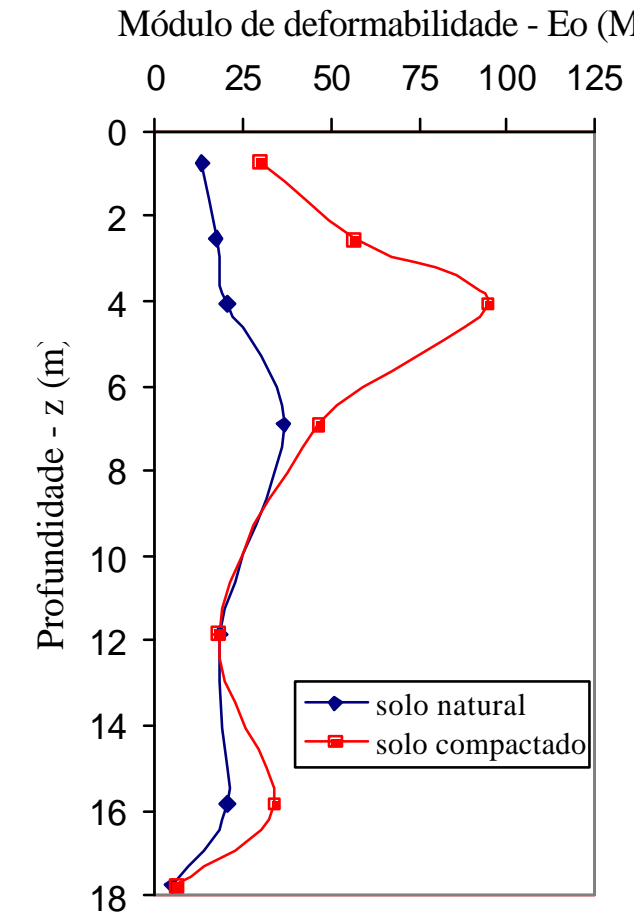

Figura 5.7 - Vale Verzasca: Gráfico de $\mathrm{E}_{0}$ x z para solo natural e compactado 


\section{Maison Elizabeth}

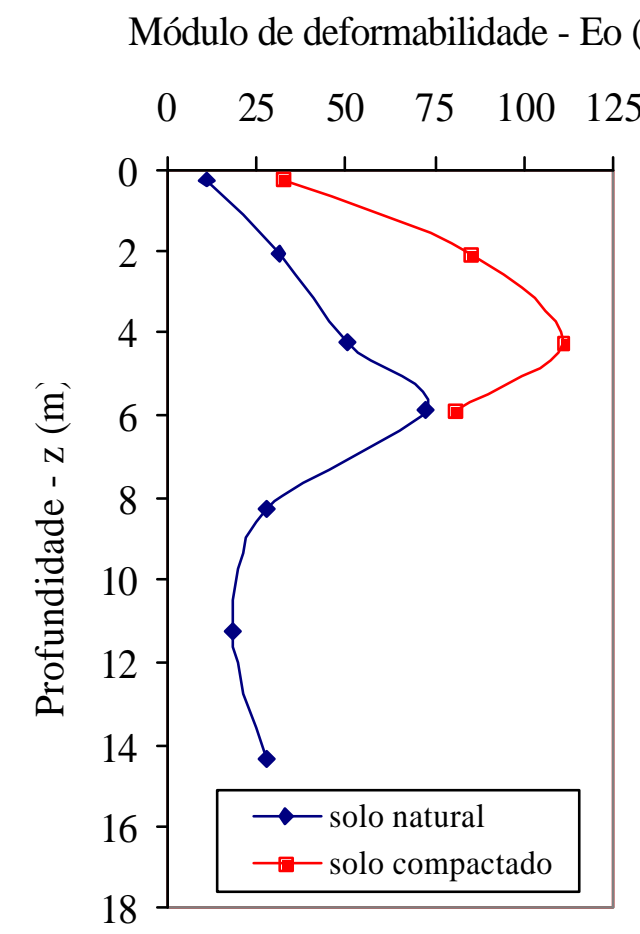

Figura 5.8 - Maison Elizabeth: Gráfico de $\mathrm{E}_{0}$ x z para solo natural e compactado

\section{Boulevard Manaíra}

Módulo de deformabilidade - Eo (MPa)

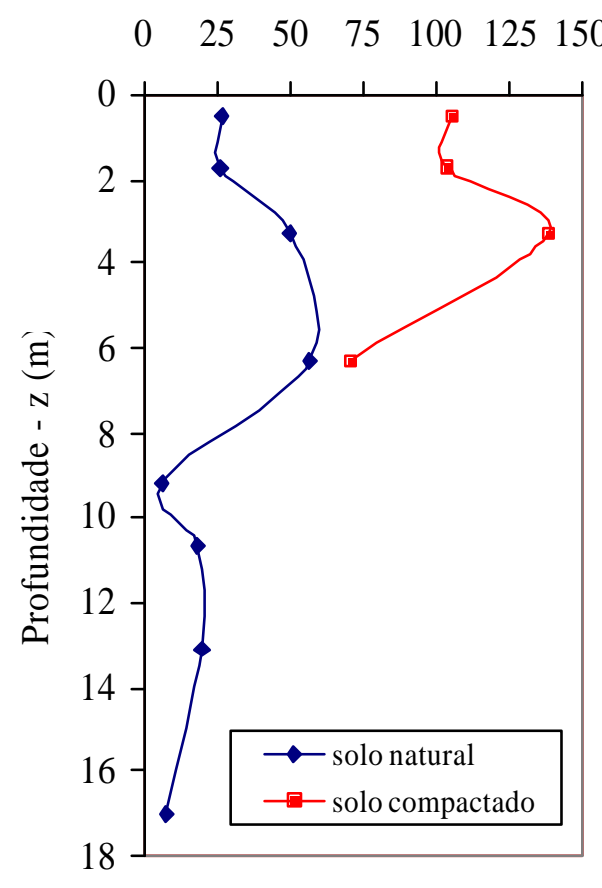

Figura 5.9 - Boulevard Manaíra: Gráfico de $\mathrm{E}_{0}$ x z para solo natural e compactado 


\section{Stéphano}

Módulo de deformabilidade - Eo (MPa)

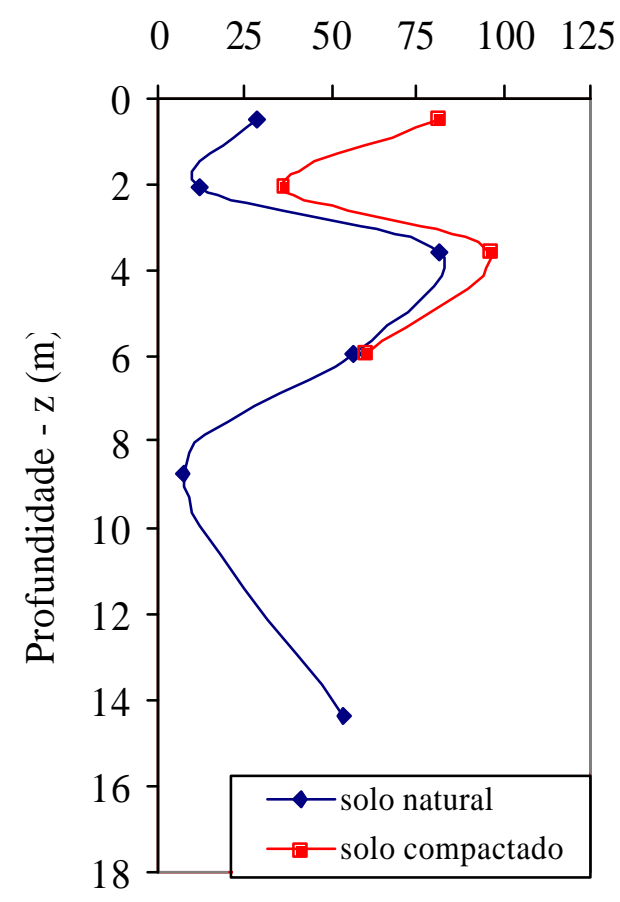

Figura 5.10 - Stéphano: Gráfico de $\mathrm{E}_{0}$ x z para solo natural e compactado

\subsubsection{Recalques}

As Figuras 5.11 a 5.26 apresentam as curvas de isorecalque, obtidas a partir dos recalques totais estimados com o módulo de deformabilidade inicial $\left(\mathrm{E}_{0}\right)$ adotado, para os casos de solo natural e compactado sob os edifícios. 


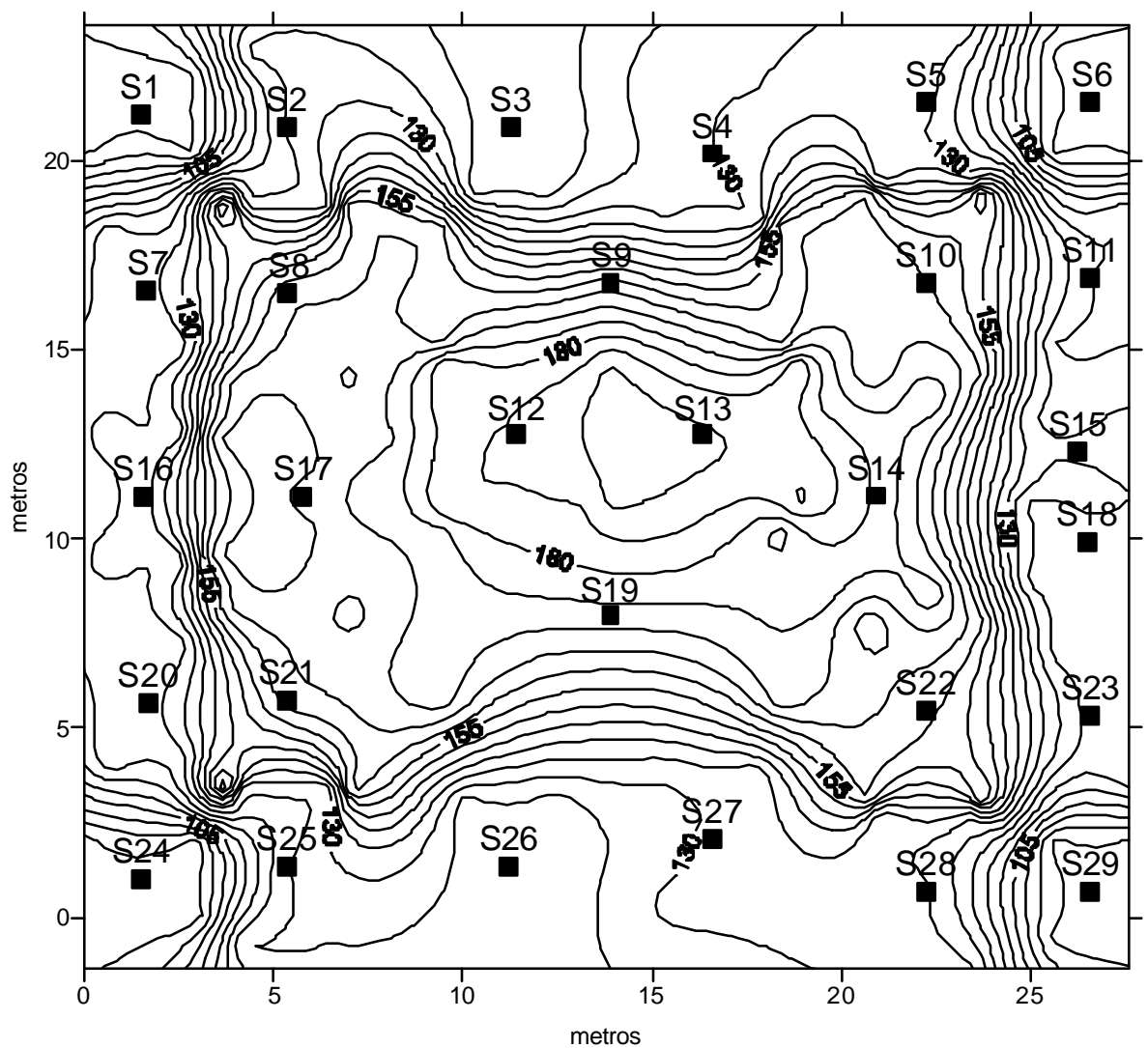

Figura 5.11 - Maison des Princes: curvas de isorecalques totais para solo natural (mm)

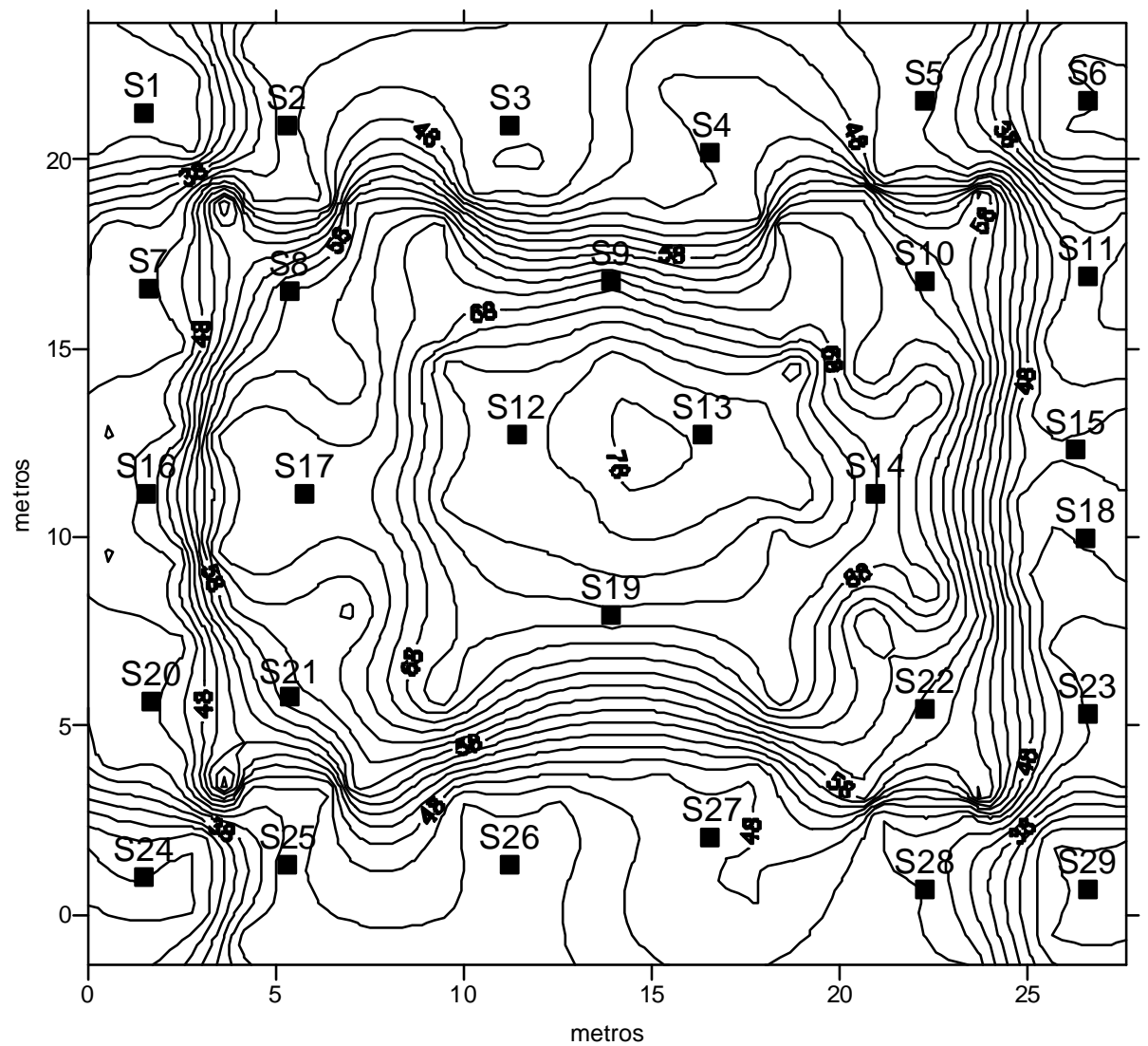

Figura 5.12 - Maison des Princes: curvas de isorecalques totais para solo compactado (mm) 


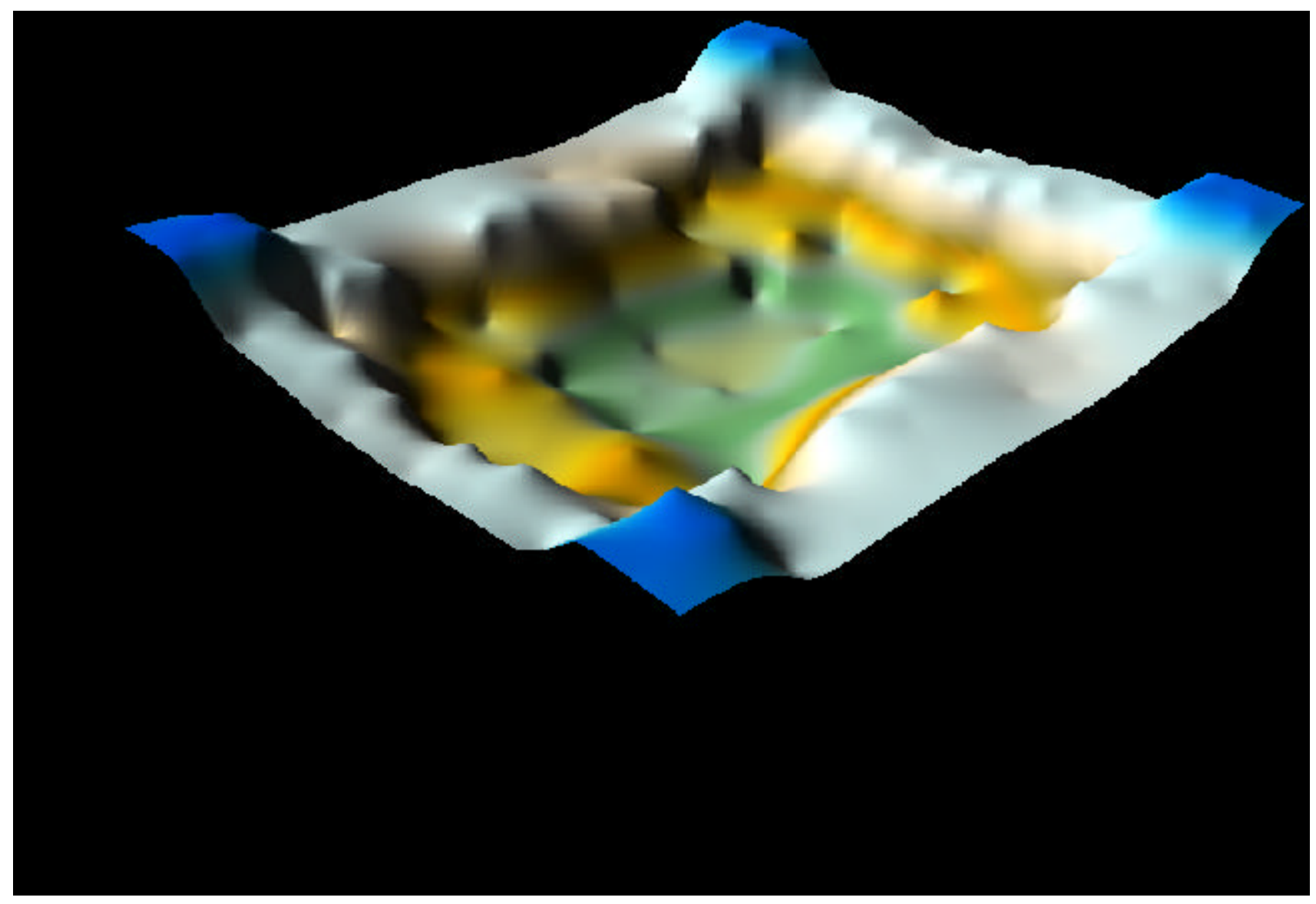

Figura 5.13 - Maison des Princes: superfície de isorecalques totais para solo compactado 


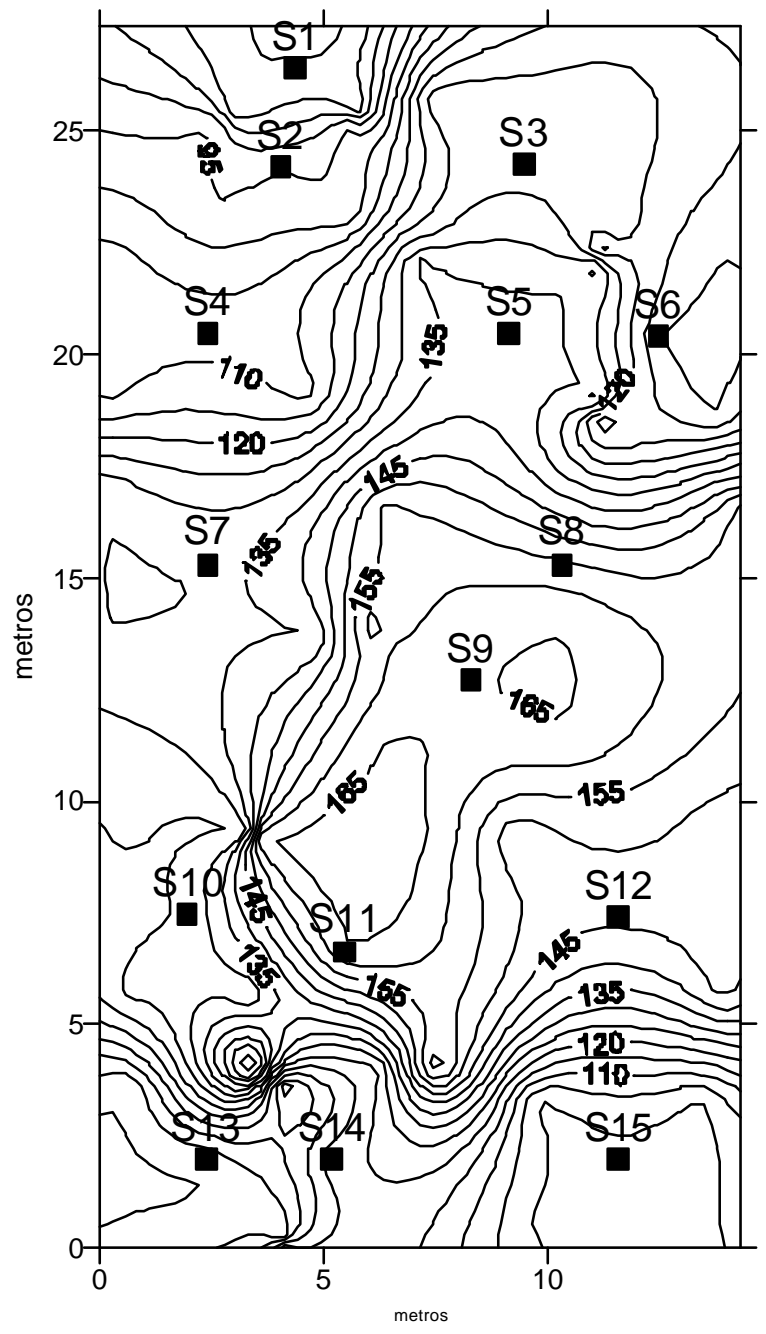

Figura 5.14 - Vale Verzasca: curvas de isorecalques totais para solo natural $(\mathrm{mm})$

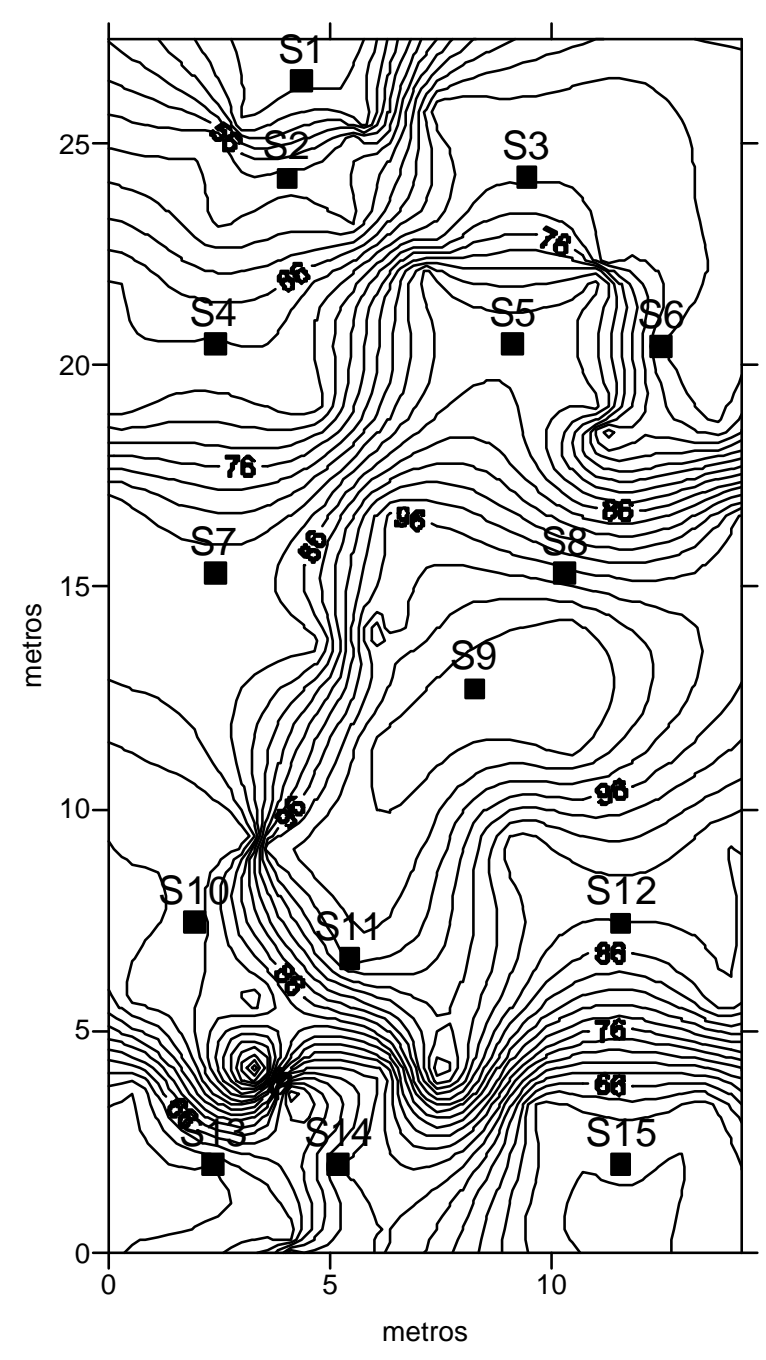

Figura 5.15 - Vale Verzasca: curvas de isorecalques totais para solo compactado $(\mathrm{mm})$ 


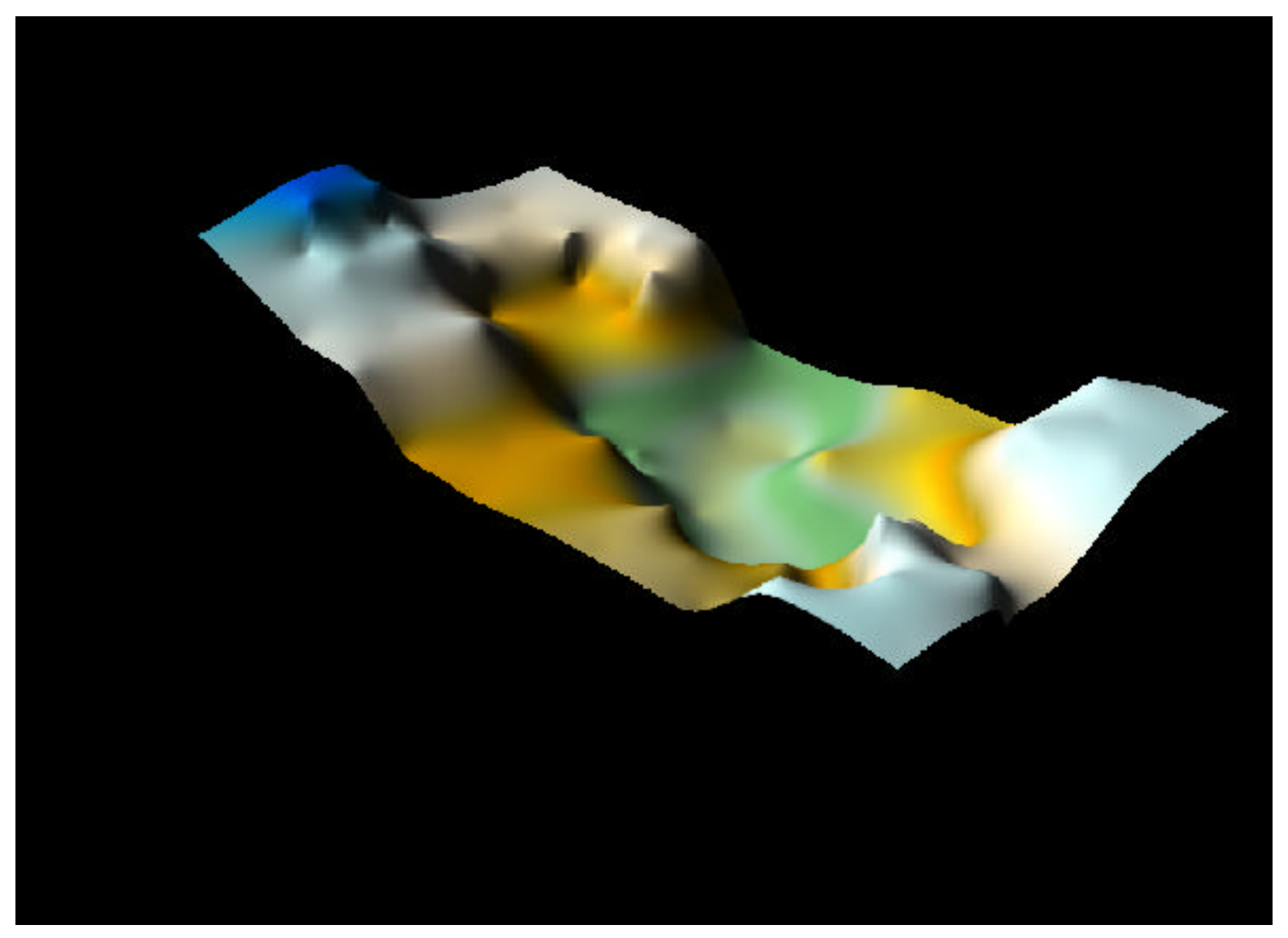

Figura 5.16 - Vale Verzasca: superfície de isorecalques totais para solo compactado 


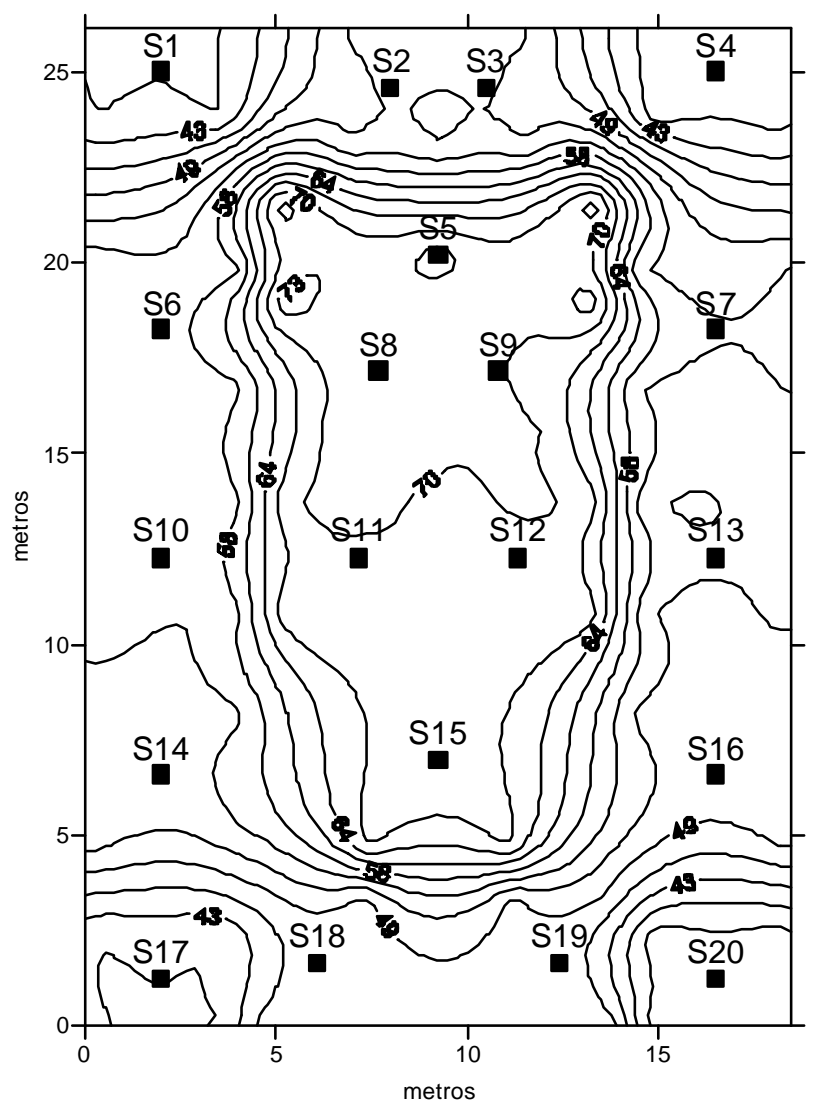

Figura 5.17 - Maison Elizabeth: curvas de isorecalques totais para solo natural (mm)

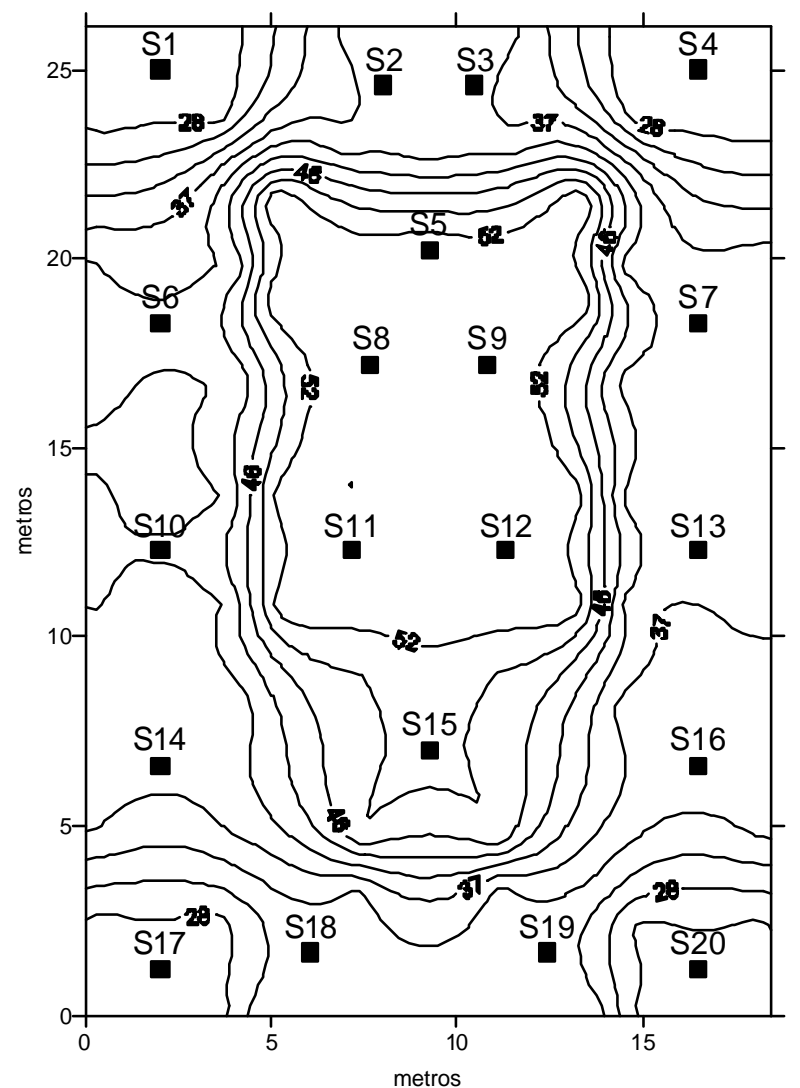

Figura 5.18- Maison Elizabeth: curvas de isorecalques totais para solo compactado (mm) 


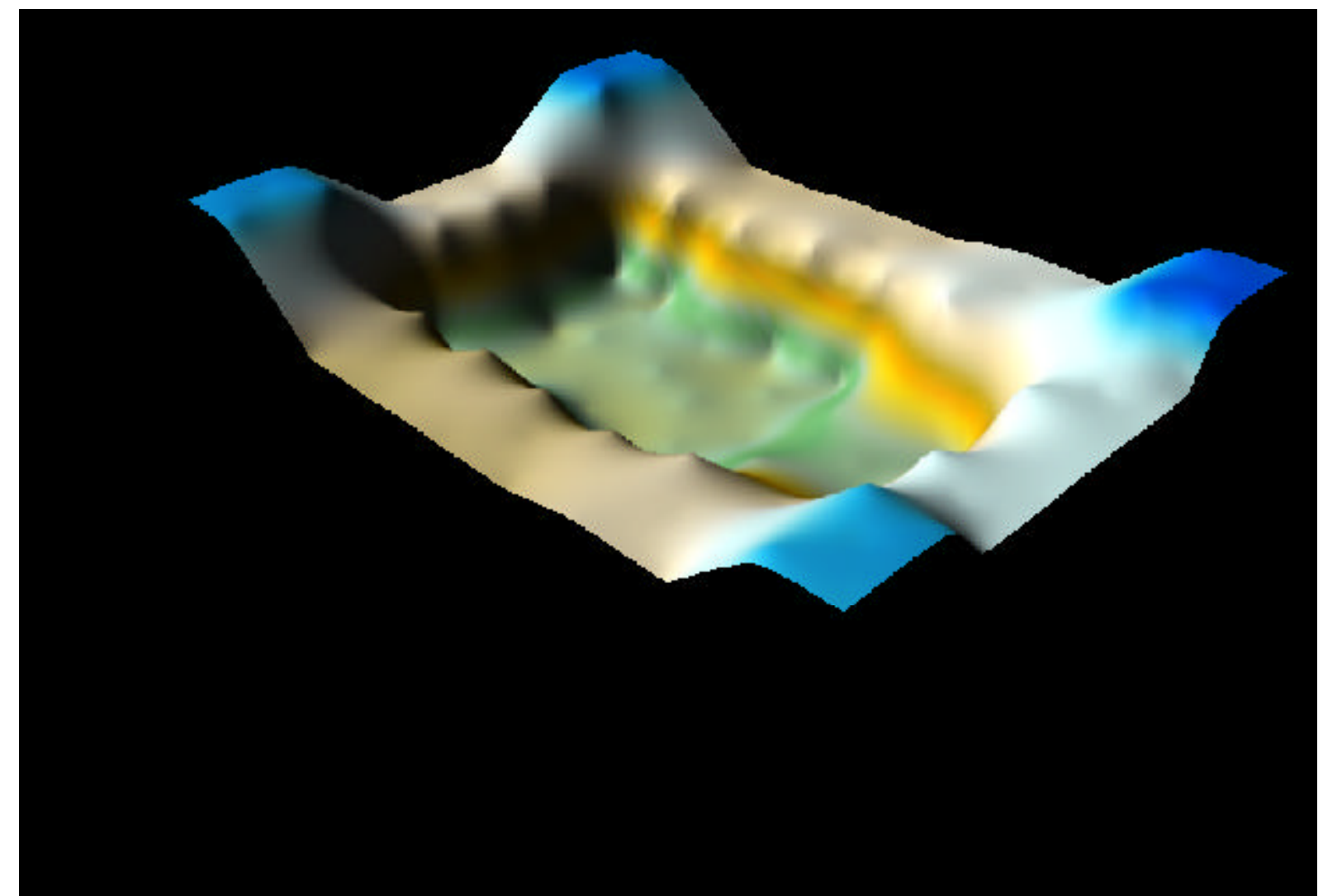

Figura 5.19 - Maison Elizabeth: superfície de isorecalques totais para solo compactado 


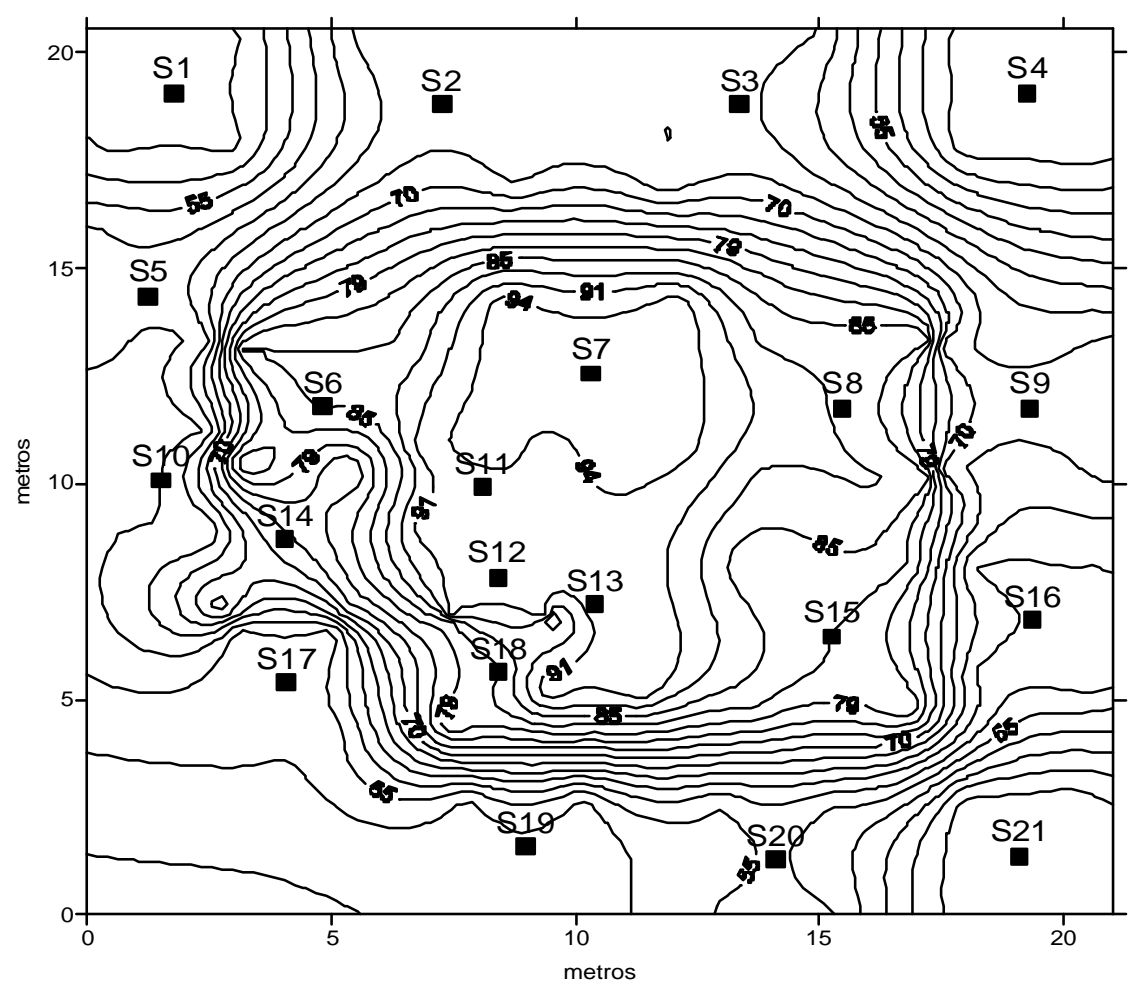

Figura 5.20 - Boulevard Manaíra: curvas de isorecalques totais para solo natural (mm)

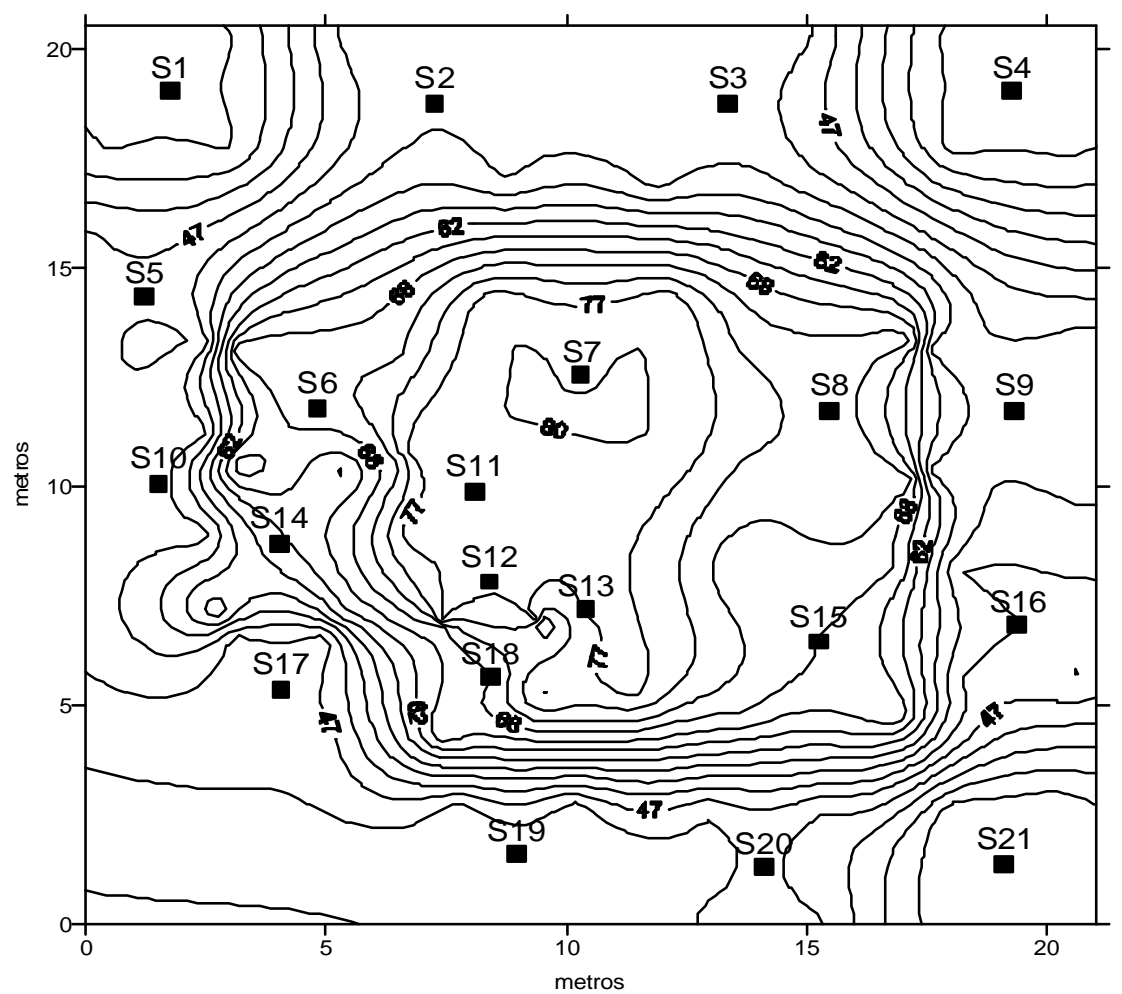

Figura 5.21 - Boulevard Manaíra: curvas de isorecalques totais para solo compactado (mm) 


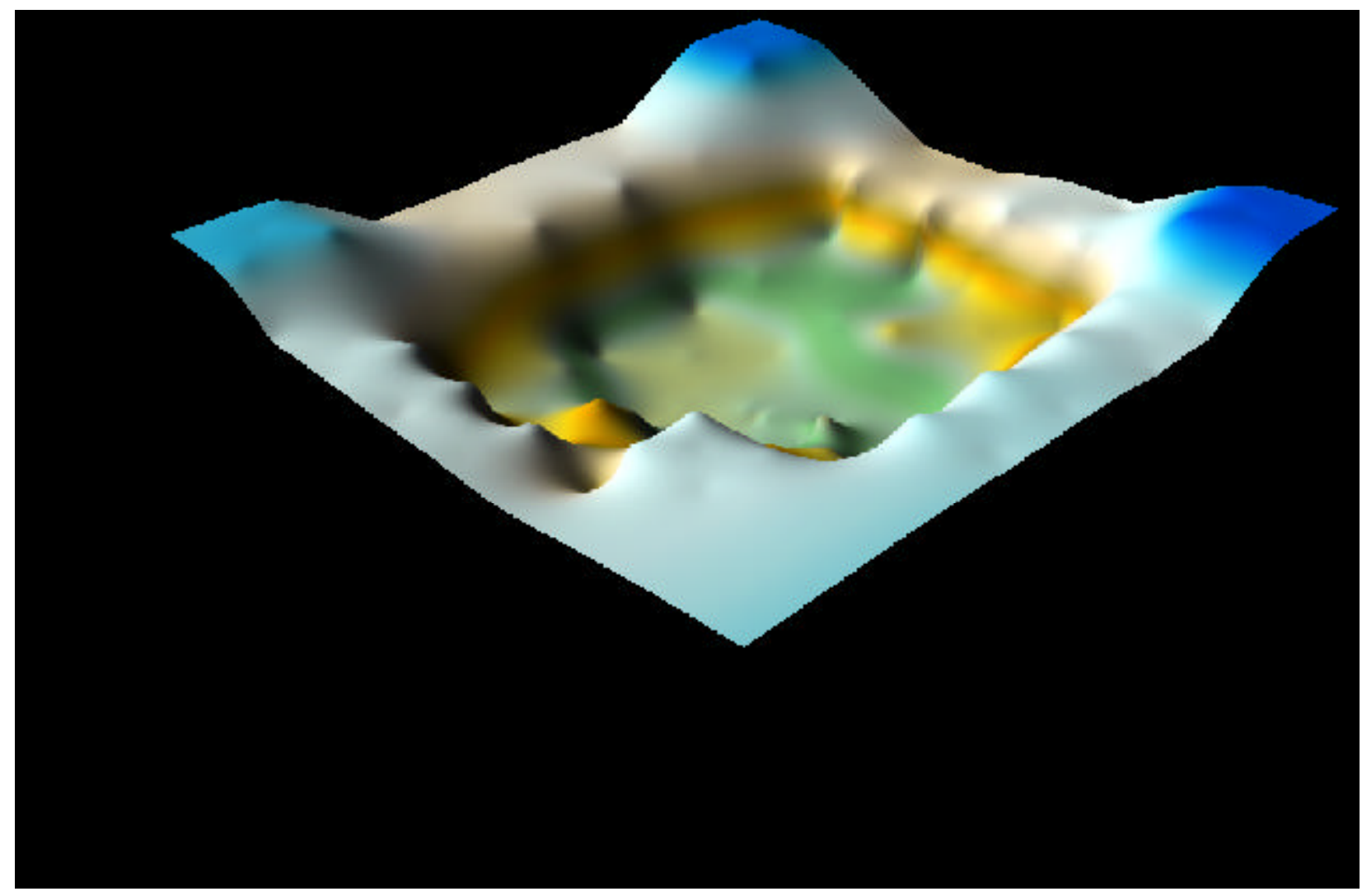

Figura 5.22 -Boulevard Manaíra: superfície de isorecalques totais para solo compactado 


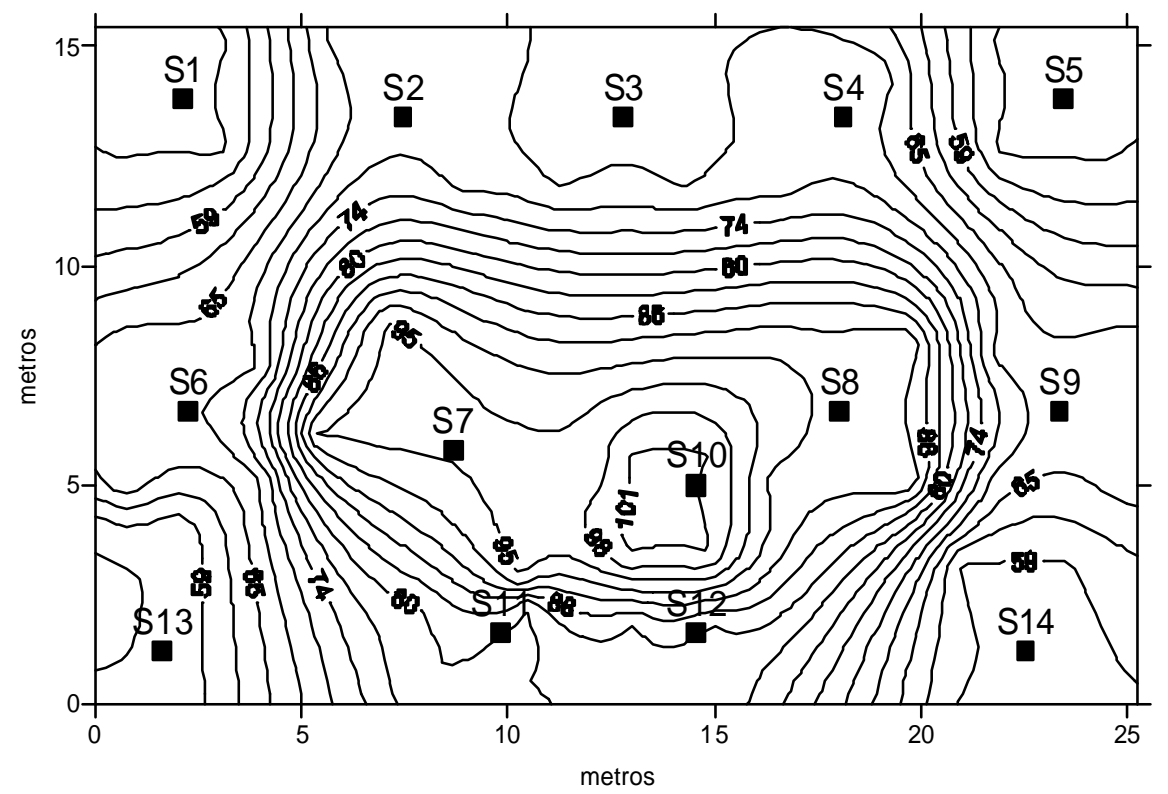

Figura 5.23 - Stéphano: curvas de isorecalques totais para solo natural (mm)

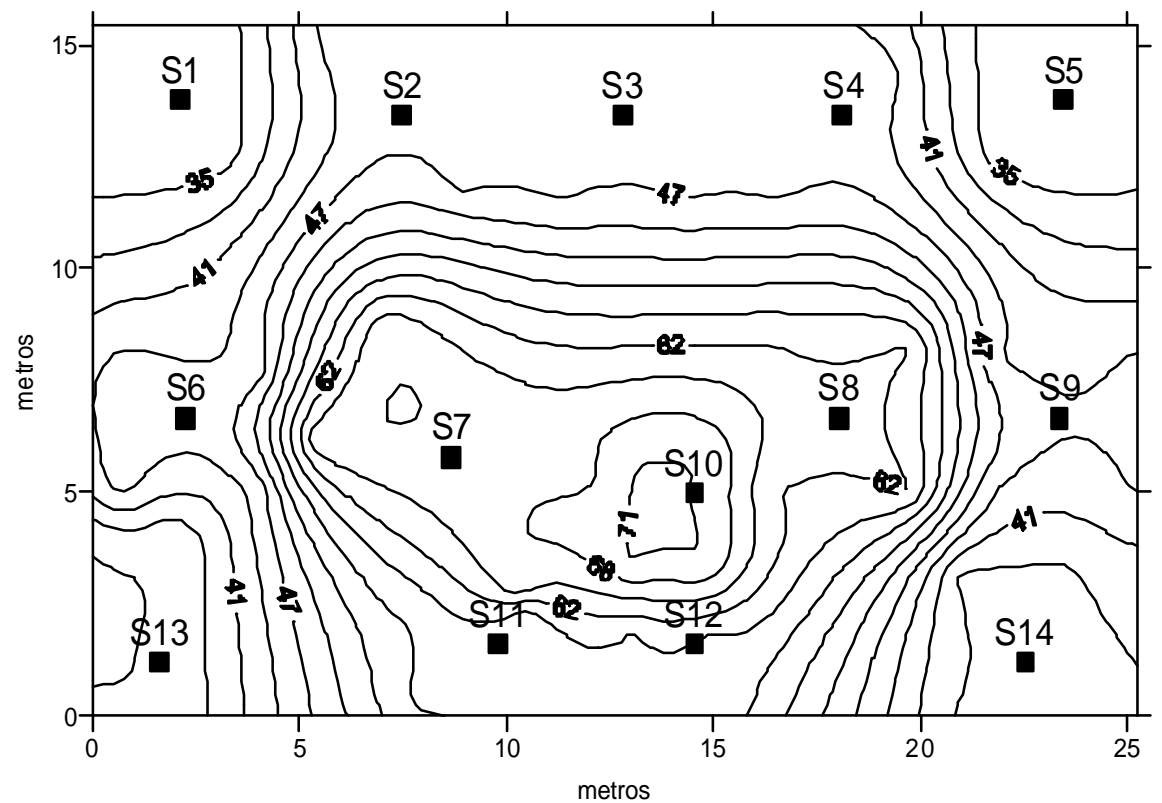

Figura 5.24 - Stéphano: curvas de isorecalques totais para solo compactado (mm) 


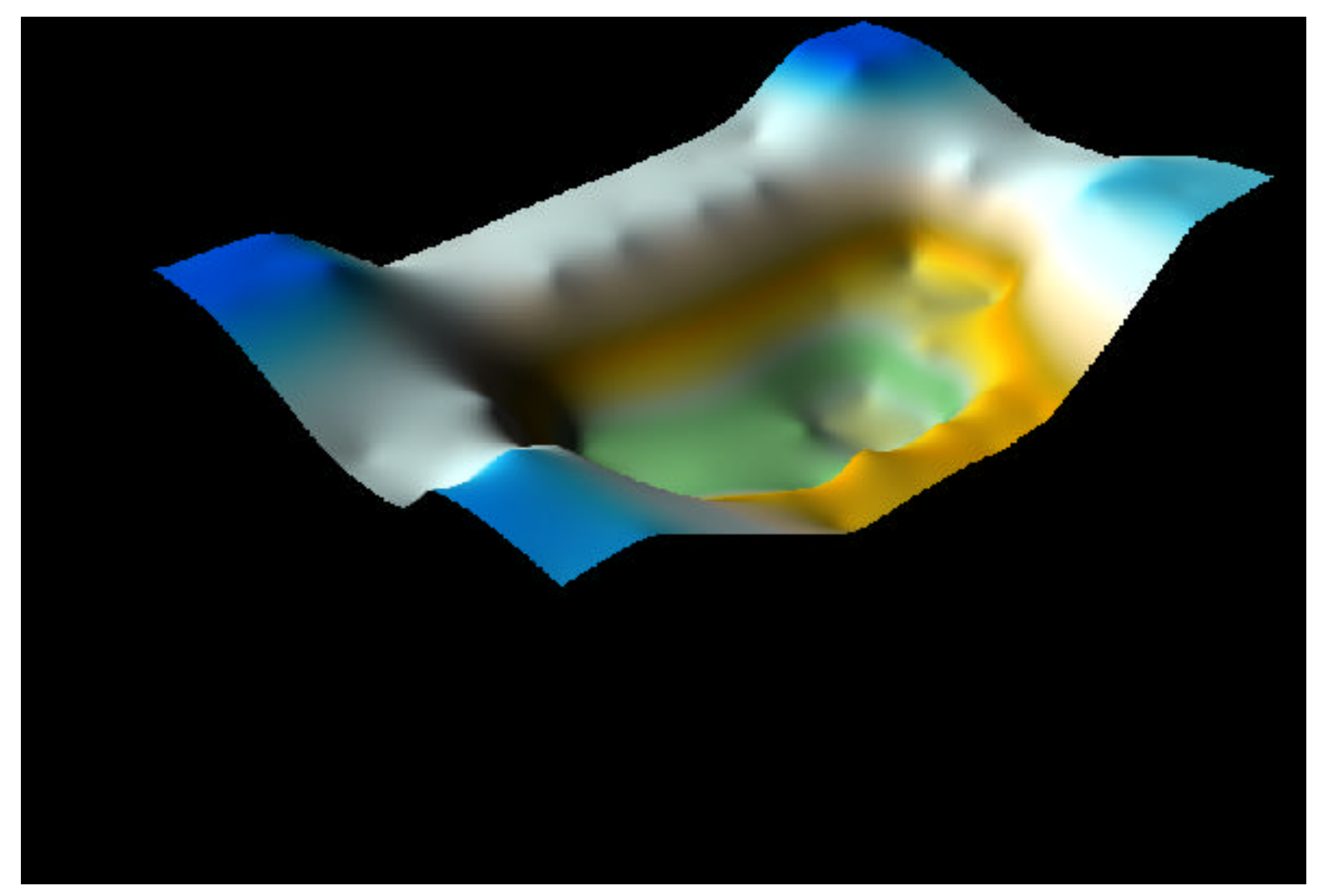

Figura 5.25 - Stéphano: superfície de isorecalques totais para solo compactado 


\section{Análise dos Resultados}

\subsection{Monitoramento}

As sapatas de três edifícios, monitorados de 2001 a 2004, o Maison des Princes, Vale Verzasca e Maison Elizabeth, apresentaram recalques em torno de $40 \mathrm{~mm}$, sendo o maior de $44 \mathrm{~mm}$. As únicas sapatas adjacentes incluídas no monitoramento foram a S2 e S3 do Vale Verzasca. O recalque diferencial obtido entre as duas foi de $2 \mathrm{~mm}$, valor bastante inferior ao sugerido por Terzaghi \& Peck (1967), de $20 \mathrm{~mm}$, como recalque diferencial admissível. O recalque diferencial específico entre as duas foi de $1 / 2700$, muito menor que o valor limite de 1/300 proposto por Skempton-MacDonald.

Não foi observado nenhum tipo de dano relacionado a essa ordem de grandeza de recalque nos edifícios mencionados, mesmo decorrido mais de um ano da última leitura e do fim das construções. 
As sapatas de dois edifícios, que continuam sendo monitorados, os residenciais Boulevard Manaíra e Stéphano, apresentaram recalques em torno de $6 \mathrm{~mm}$.

Observa-se que os recalques das sapatas centrais foram maiores que os das de extremidade em todos os cinco casos.

\subsubsection{Carregamento}

Para uma análise da evolução dos recalques monitorados de acordo com a aplicação de carga, foi adotada a distribuição de cargas admitida por Gusmão et al.(2000). Nesta, as fases construtivas dos edifícios (concreto, alvenarias, revestimento, pisos etc.) correspondem a carregamentos percentuais em relação ao total. As Figuras 6.1 a 6.5 mostram os gráficos tempo $\mathrm{x}$ recalque $\mathrm{x}$ carregamento das sapatas dos edifícios com o tempo $=0$ correspondente ao início do monitoramento.

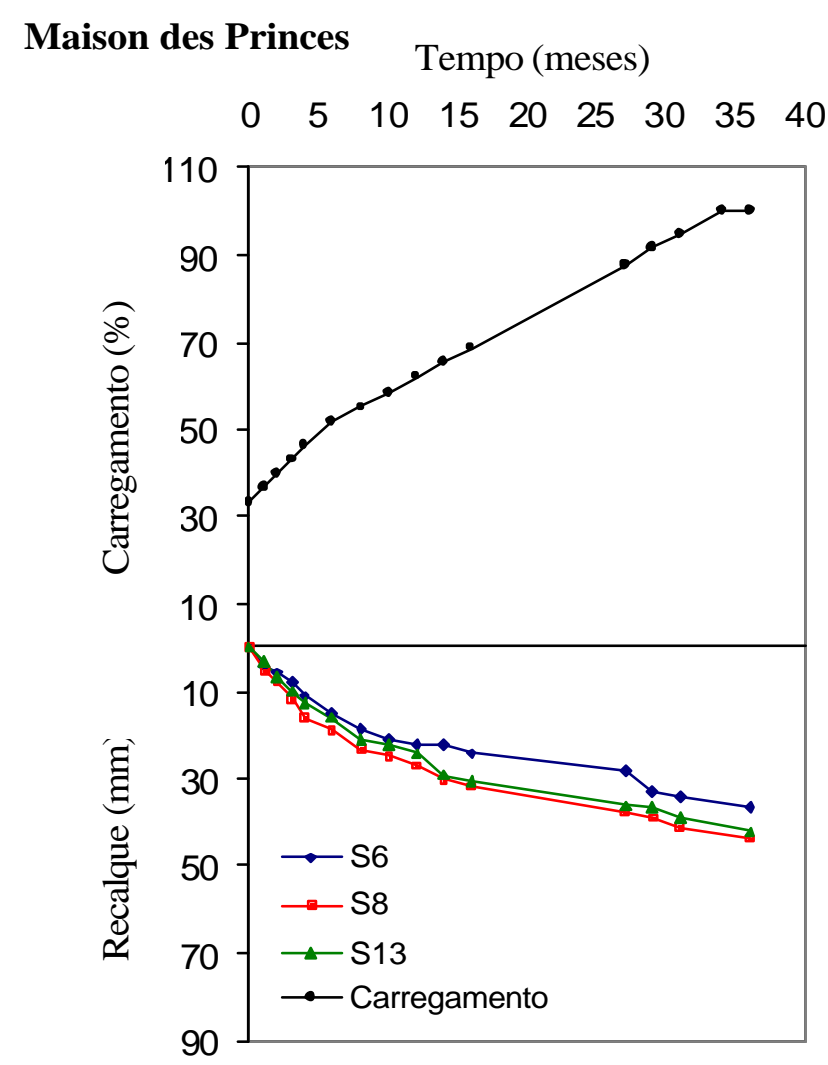

Figura 6.1 - Maison des Princes: gráfico tempo x recalque x carregamento de três sapatas 
Vale Verzasca Tempo (meses)

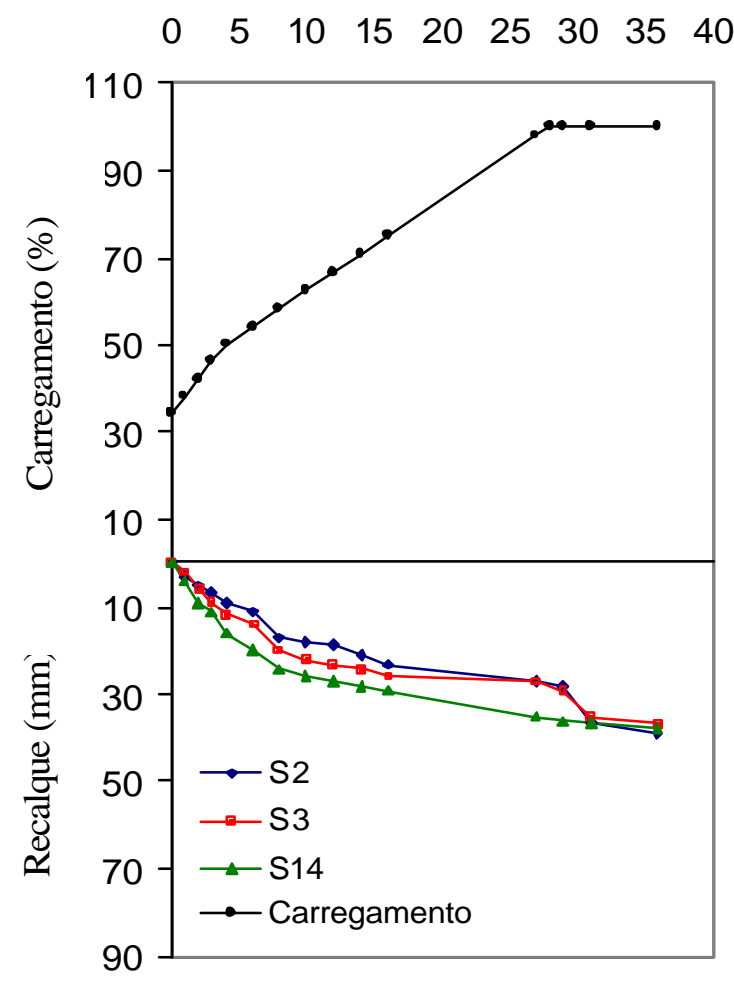

Figura 6.2 - Vale Verzasca: gráfico tempo x recalque x carregamento de três sapatas

\section{Maison Elizabeth} Tempo (meses)

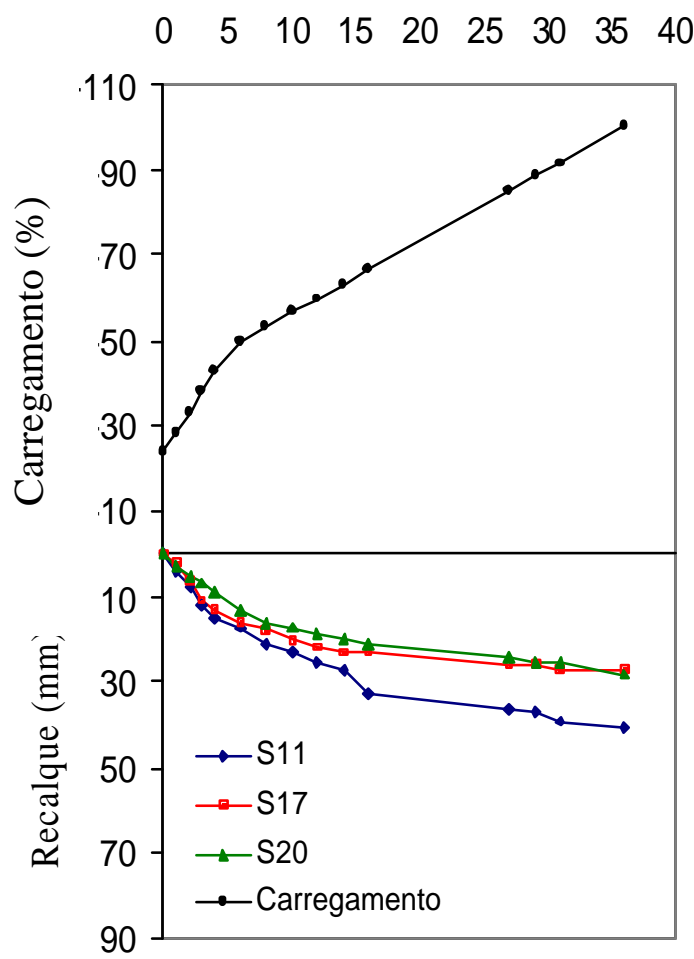

Figura 6.3 - Maison Elizabeth: gráfico tempo x recalque x carregamento de três sapatas 


\section{Boulevard Manaíra}

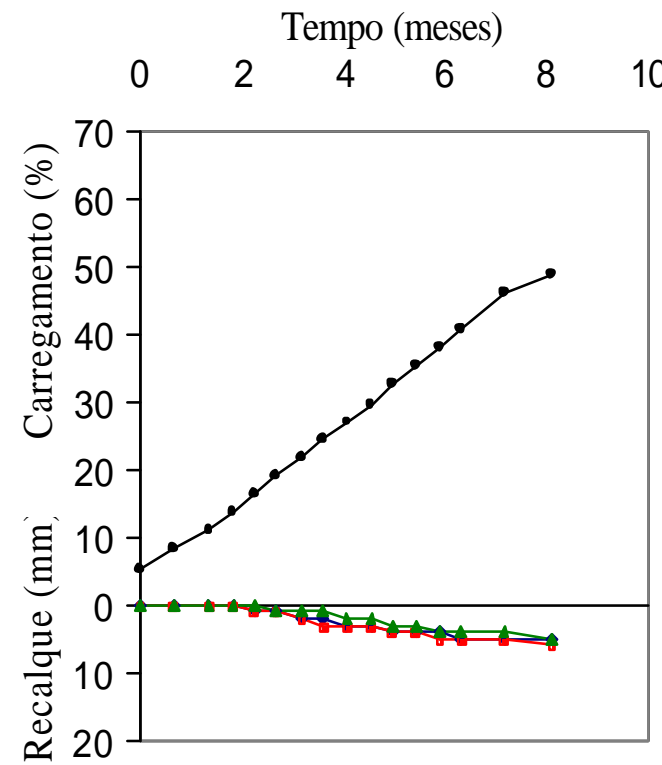

$\rightarrow \mathrm{S} 1 \rightarrow \mathrm{S} 7 \rightarrow \mathrm{S} 21 \rightarrow$ Carregamento

Figura 6.4 - Boulevard Manaíra: gráfico tempo x recalque x carregamento de três sapatas

\section{Stéphano}

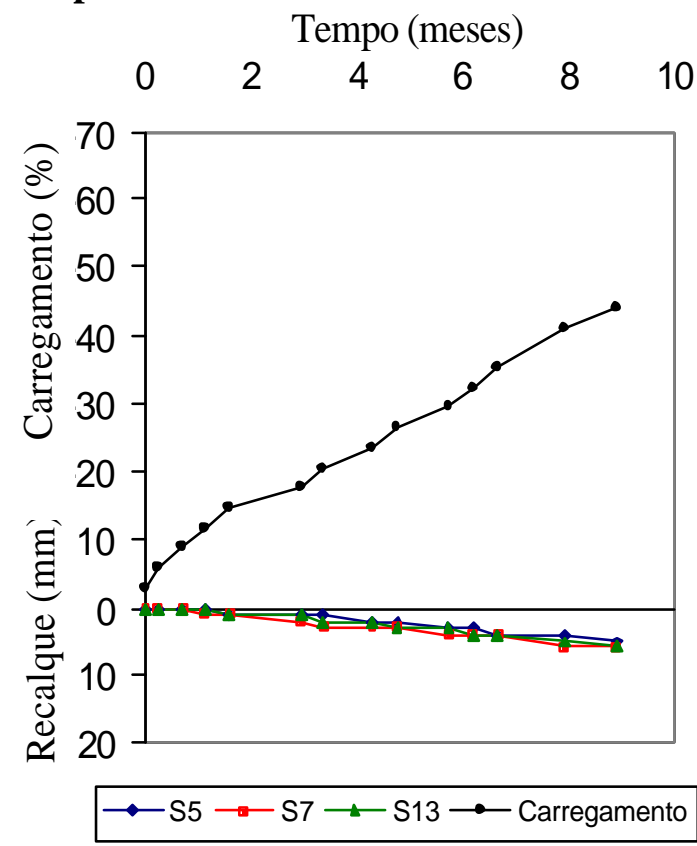

Figura 6.5 - Stéphano: gráfico tempo x recalque x carregamento de três sapatas 
Compararam-se os recalques dos dois últimos edifícios com os da situação analisada por Lucena et al. (2004). Os autores monitoraram, desde o início de construção, os recalques de todos os pilares do edifício Mar da Galiléia, em João Pessoa, com sapatas assentes em solo melhorado com estacas de compactação. O recalque médio obtido pelos autores foi 4,3 mm para $50 \%$ de carregamento contra $4,7 \mathrm{~mm}$ de recalque médio das sapatas do Boulevard Manaíra na mesma fase de carregamento. Obtiveram também um recalque médio de 3,5 mm para $44 \%$ da carga, enquanto as sapatas monitoradas do Stéphano sofreram $5,7 \mathrm{~mm}$ de recalque médio para o mesmo carregamento.

\subsubsection{Velocidades de recalque}

As Figuras 6.6 a 6.10 mostram as velocidades dos recalques obtidos com o tempo $=0$ sendo o início do monitoramento.

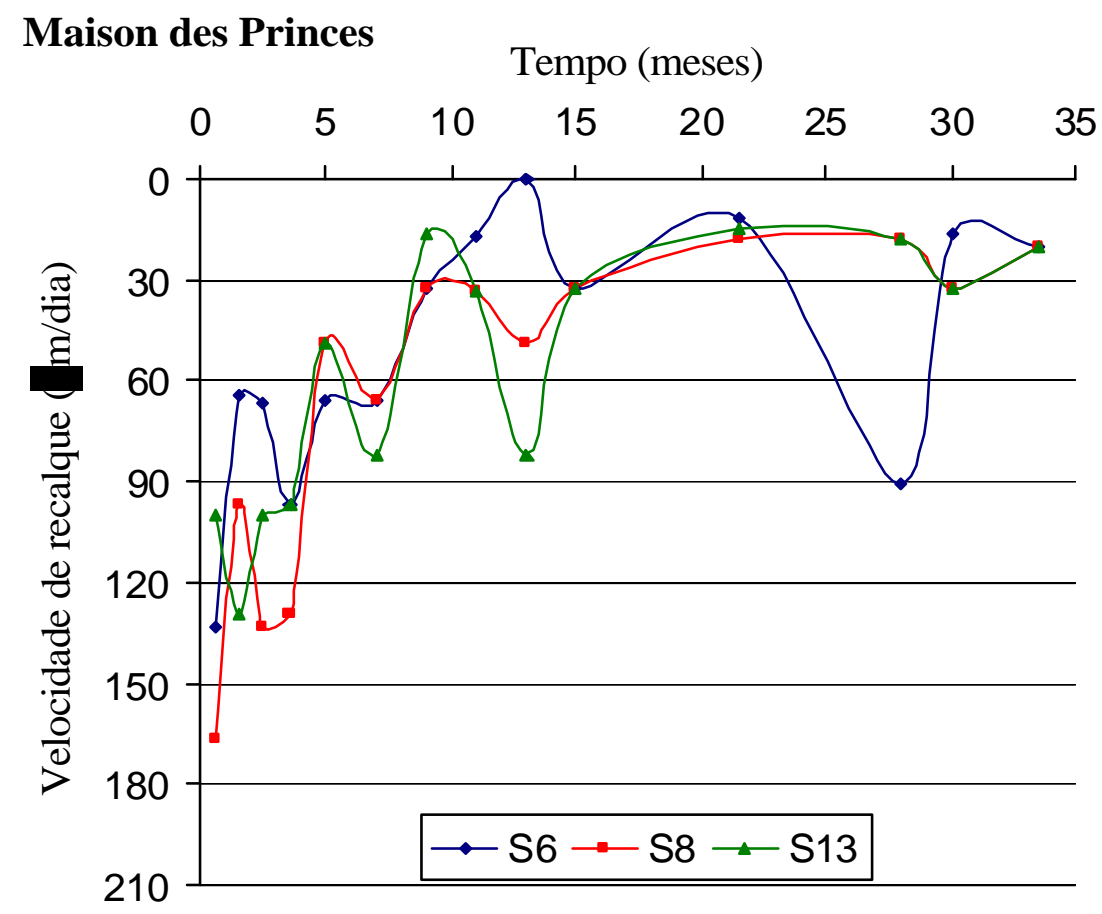

Figura 6.6 - Maison des Princes: gráfico tempo x velocidade de recalque de três sapatas 
Vale Verzasca

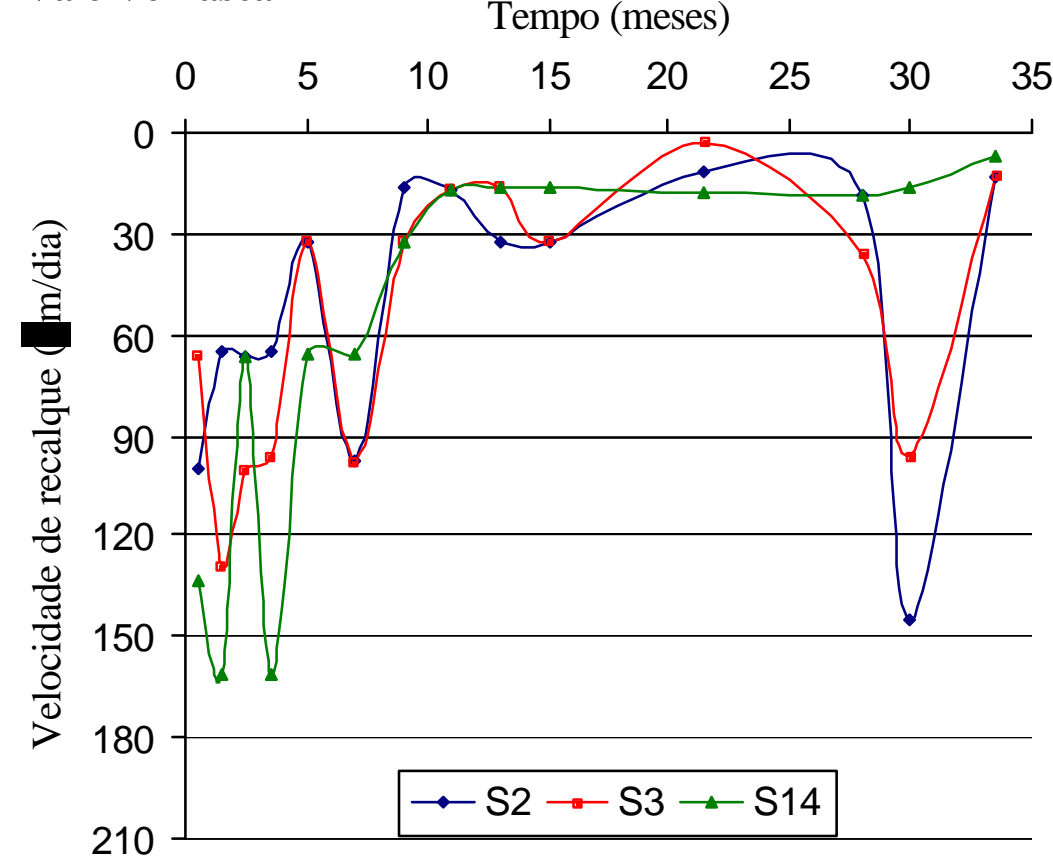

Figura 6.7 - Vale Verzasca: gráfico tempo x velocidade de recalque de três sapatas

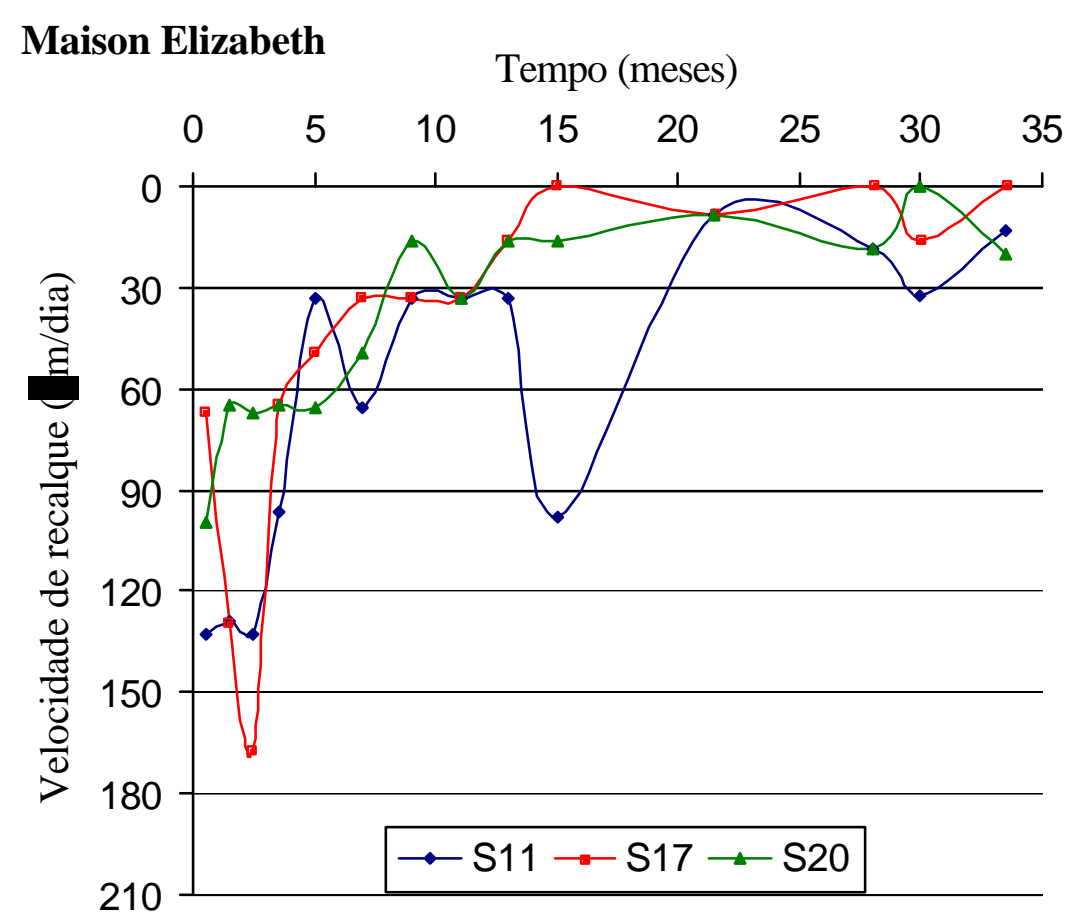

Figura 6.8 - Maison Elizabeth: gráfico tempo x velocidade de recalque de três sapatas 


\section{Boulevard Manaíra}

Tempo (meses)

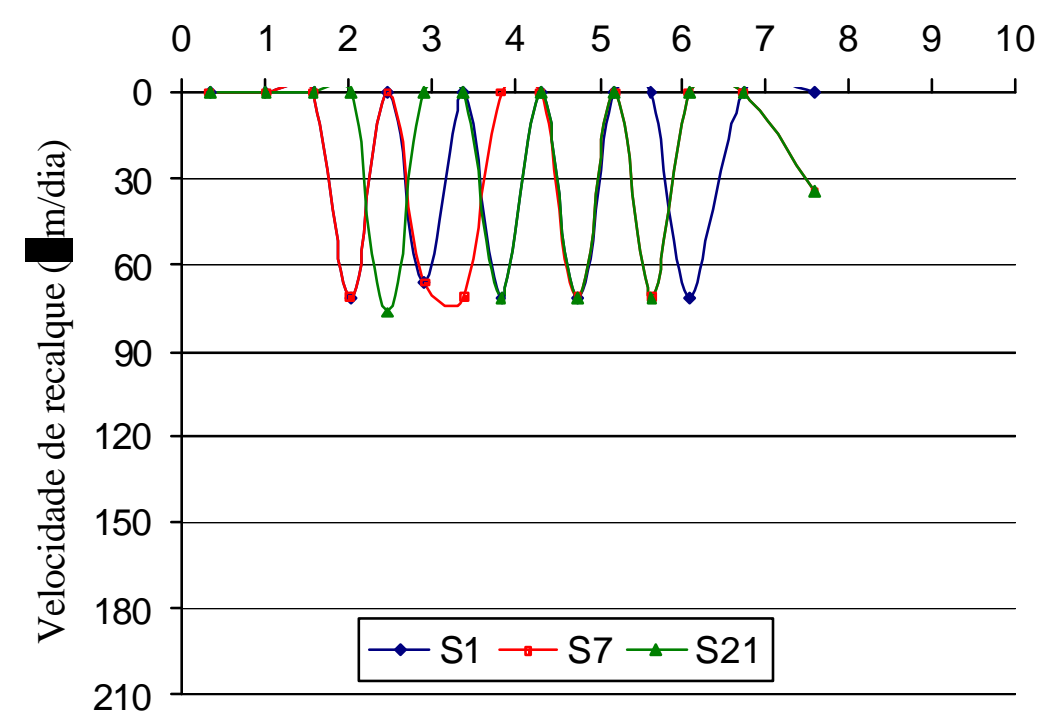

Figura 6.9 - Boulevard Manaíra: gráfico tempo x velocidade de recalque de três sapatas

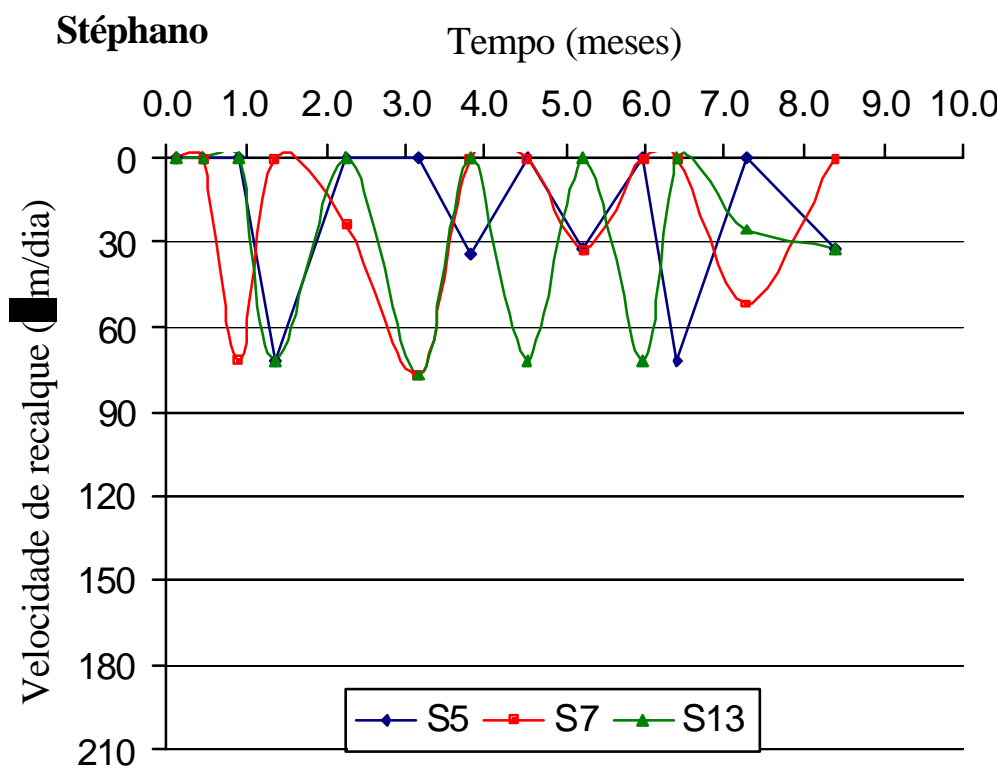

Figura 6.10 - Stéphano: gráfico tempo x velocidade de recalque de três sapatas

Nos três primeiros edifícios, observa-se uma tendência à diminuição da velocidade de recalque das sapatas com o tempo, com exceção das do Vale Verzasca, que apresentaram picos de velocidade no final do monitoramento. A isso se pode atribuir à ocorrência de algum erro nas medições. 
As velocidades não chegaram a ultrapassar a taxa de $200 \mu \mathrm{m} / \mathrm{dia}$, valor mencionado por Alonso (1991) como aceitável para construções sobre fundações diretas por sapatas.

Nos edifícios monitorados desde o início das construções, a velocidade de recalque das sapatas se mostrou nula nas primeiras medições, aparentemente devido a não ocorrência de recalque neste período. No restante, as sapatas do Boulevard Manaíra atingiram taxas de $71 \mu \mathrm{m} /$ dia, alternadas com $35 \mu \mathrm{m} /$ dia e até com $0 \mu \mathrm{m} / \mathrm{dia}$. Assim como as velocidades das sapatas do Stéphano chegaram a valores de $77 \mu \mathrm{m} /$ dia, por sua vez alternados com $32 \mu \mathrm{m} / \mathrm{dia}$ e também com até $0 \mu \mathrm{m} /$ dia. Até a última leitura, não foi observada nenhuma tendência à redução, visto que as obras ainda não alcançaram nem metade da construção.

\subsubsection{Extrapolação}

Como os recalques das construções do Maison des Princes, Vale Verzasca e Maison Elizabeth não foram medidos desde o início, é necessário inferir um valor do recalque $\Delta$ ocorrido até o início do monitoramento. Para isso, a expressão de Massad (1982), que divulga o método gráfico de Asaoka

$$
?^{\prime}=?^{\prime}{ }_{\text {est }}\left\{1-\mathrm{e}^{-(\mathrm{at}+\beta)}\right\}
$$

foi utilizada pelo procedimento de Van der Veen generalizado. Ela é representada na Figura $6.11 \mathrm{a}$, onde se indica também a parcela de recalque $\Delta$. A partir das séries de coordenadas ( $\left(\mathrm{f}, \rho^{\prime}\right)$, nas quais t é o tempo de construção e $\rho^{\prime}$ o recalque medido, foi feita a regressão dos pontos monitorados. Ajustando-se essa expressão aos pontos medidos na monitoração, obtiveram-se curvas que foram extrapoladas de modo a se obter o valor de $\Delta \mathrm{e}$ do recalque $\rho$ ' estabilizado. 
Finalmente, adicionando-se $\Delta$ aos recalques monitorados ( $\left.\rho^{\prime}\right)$, têm-se os valores inferidos para o recalque $(\rho)$, conforme a Figura $6.11 \mathrm{~b}$.

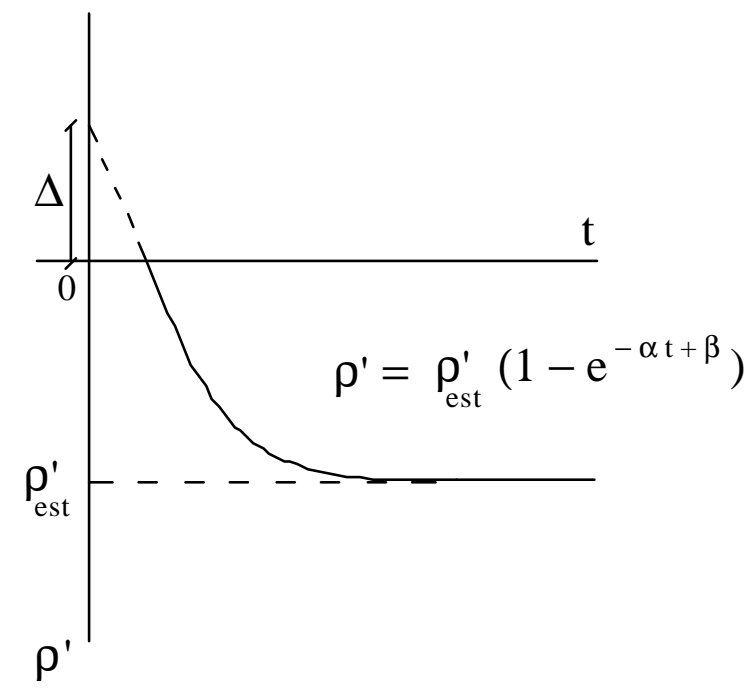

(a)

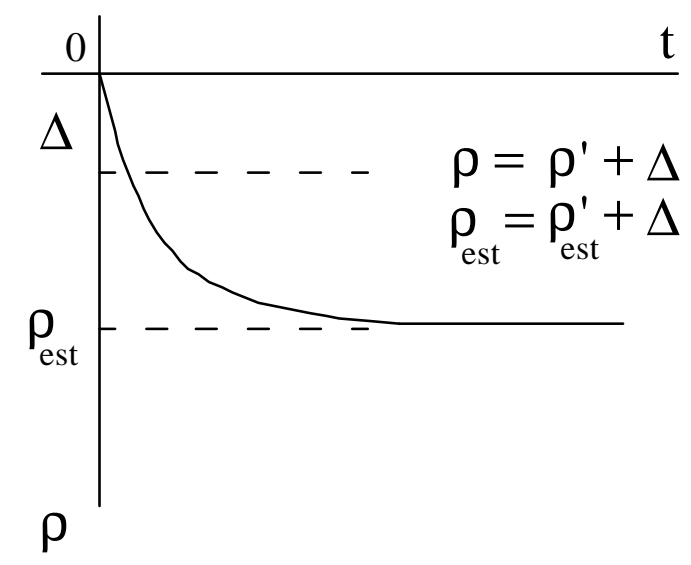

(b)

Figura 6.11 - Ajuste dos recalques medidos pela expressão de Massad (1982)

As Figuras 6.12 a 6.19 exibem os pontos obtidos com o monitoramento e as curvas provenientes do ajuste à expressão de Massad (1982). 
S6 Maison des Princes

Tempo de construção - $\mathrm{t}$ (meses)

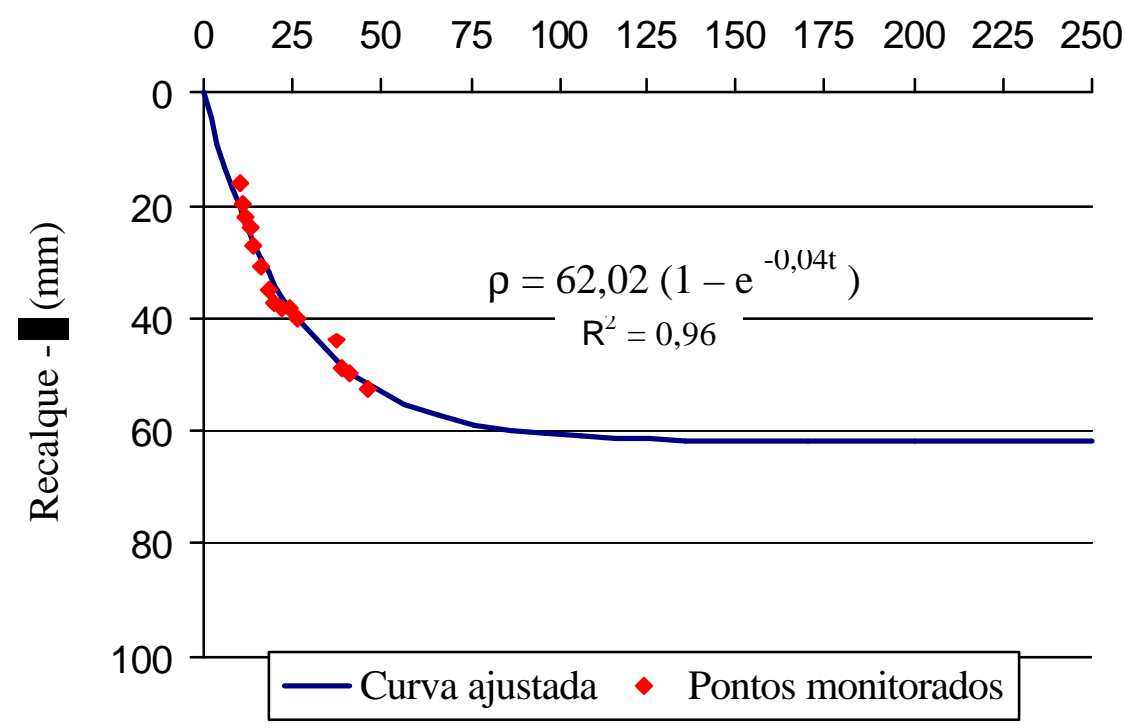

Figura 6.12 - S6 (Maison des Princes): pontos monitorados e curva ajustada

S8 Maison des Princes Tempo de construção - $t$ (meses)

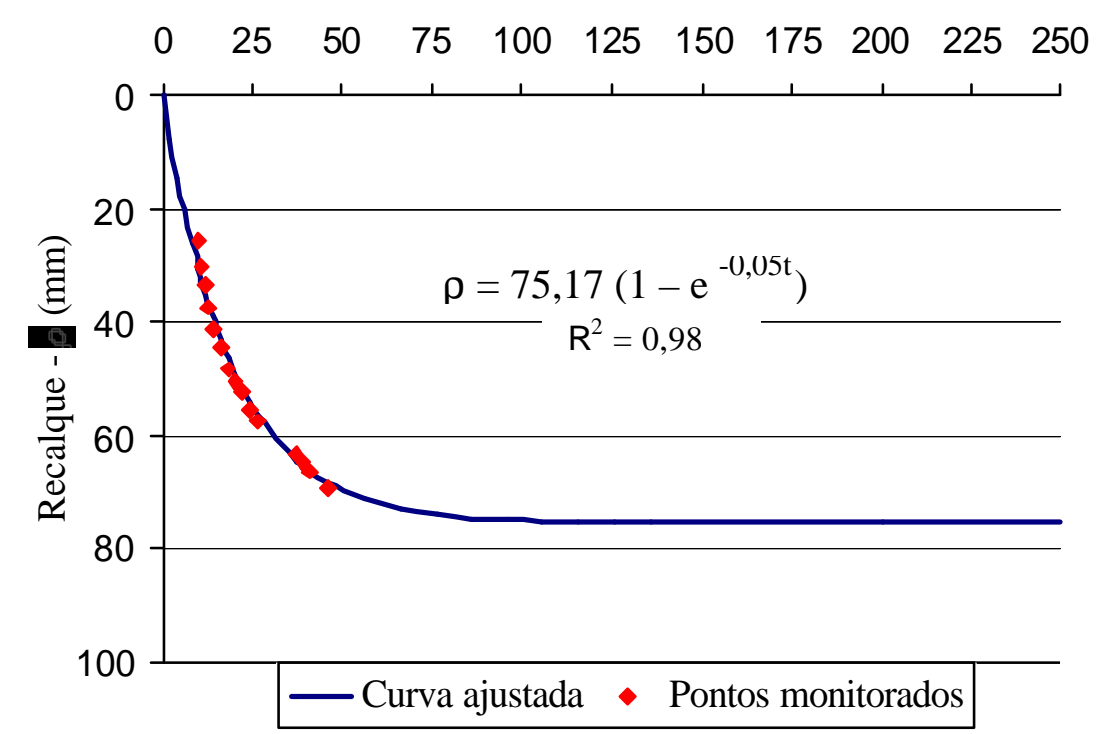

Figura 6.13 - S8 (Maison des Princes): pontos monitorados e curva ajustada 


\section{S13 Maison des Princes}

Tempo de construção - $\mathrm{t}$ (meses)

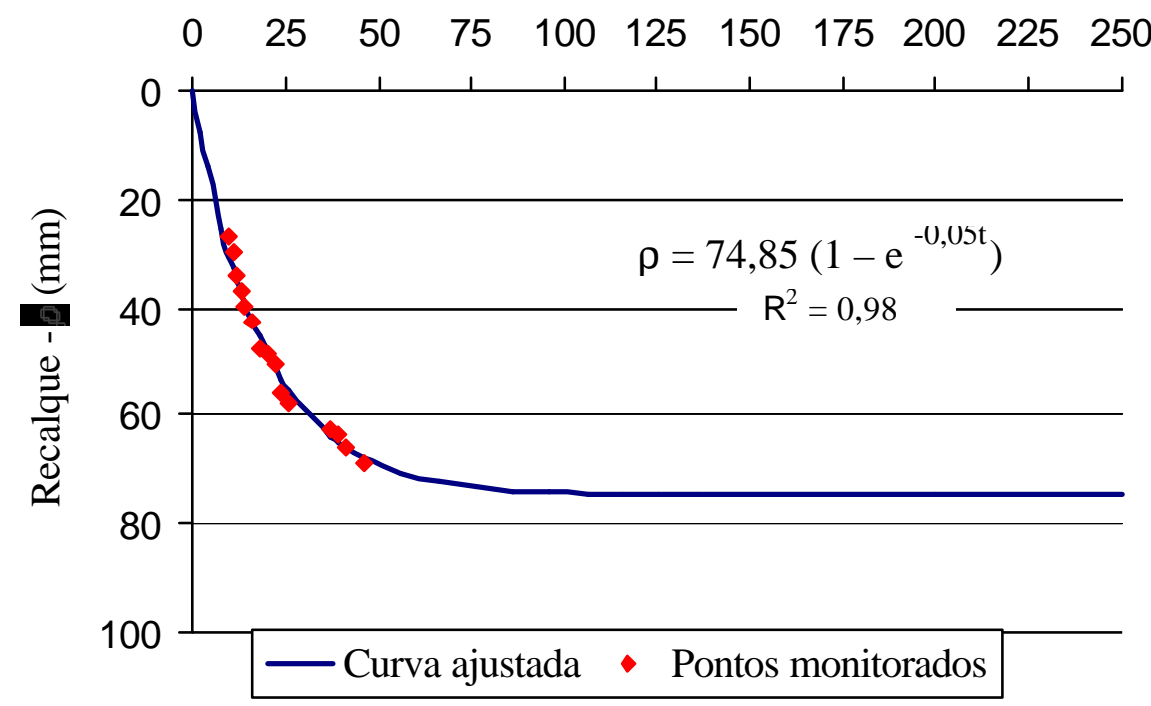

Figura 6.14 - S13 (Maison des Princes): pontos monitorados e curva ajustada

\section{S2 Vale Verzasca}

Tempo de construção - $\mathrm{t}$ (meses)

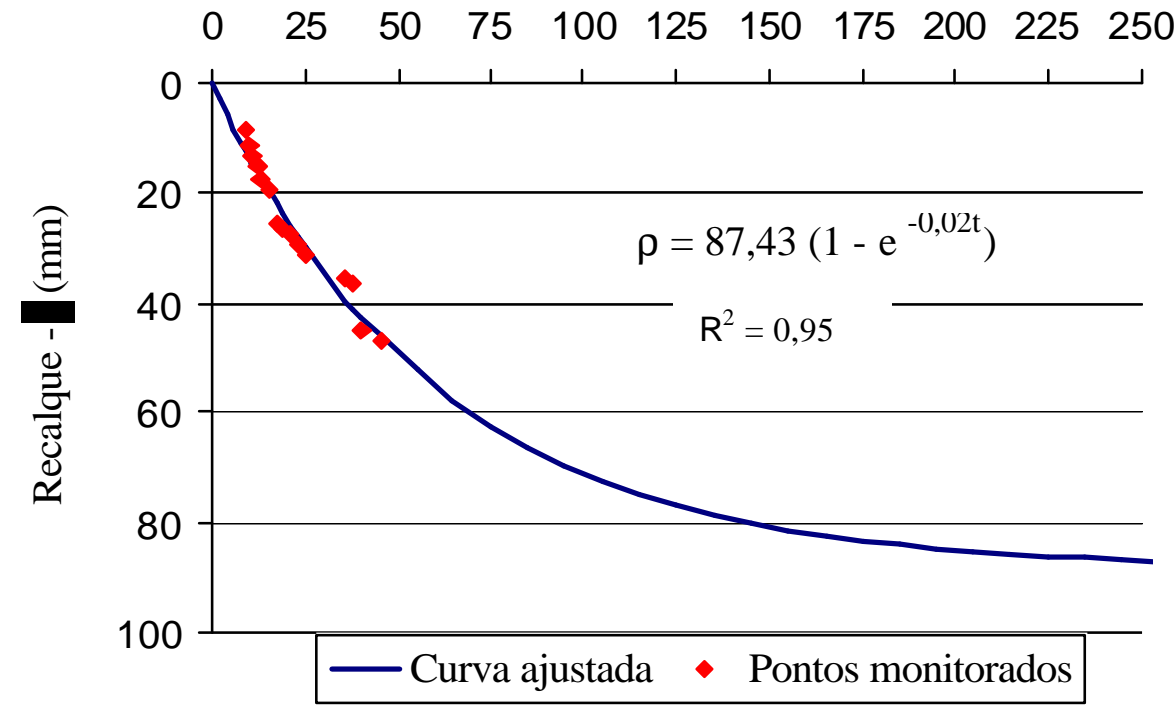

Figura 6.15 - S2 (Vale Verzasca): pontos monitorados e curva ajustada 
S3 Vale Verzasca

Tempo de construção - $\mathrm{t}$ (meses)

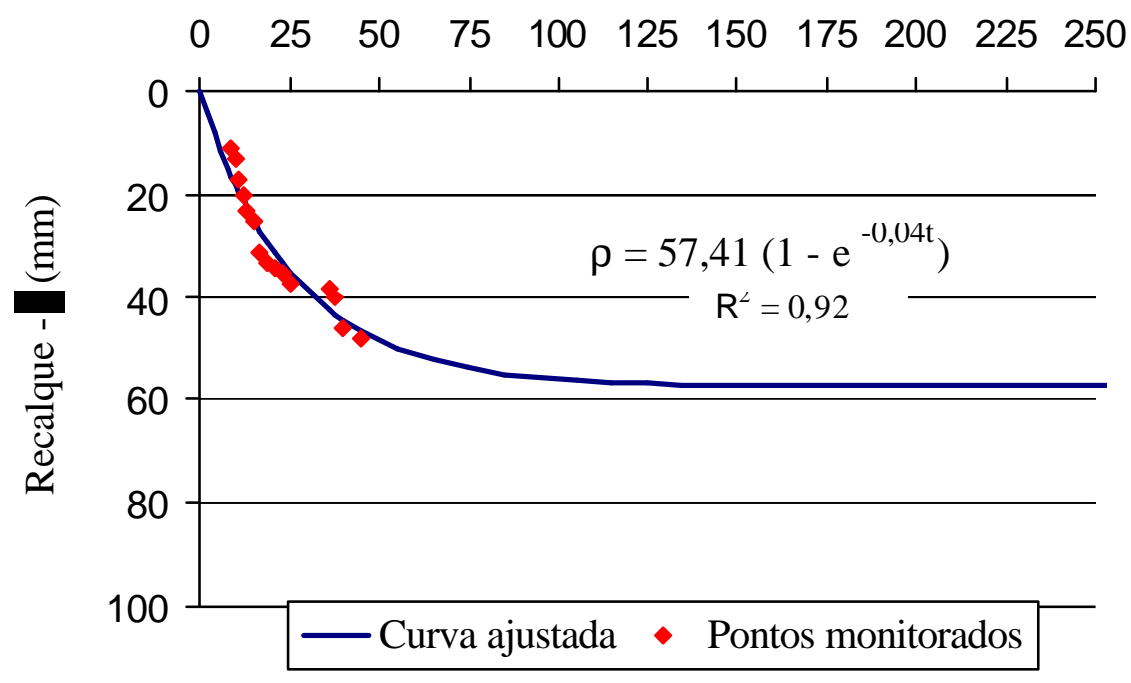

Figura 6.16 - S3 (Vale Verzasca): pontos monitorados e curva ajustada

\section{S14 Vale Verzasca}

Tempo de constrção - $\mathrm{t}$ (meses)

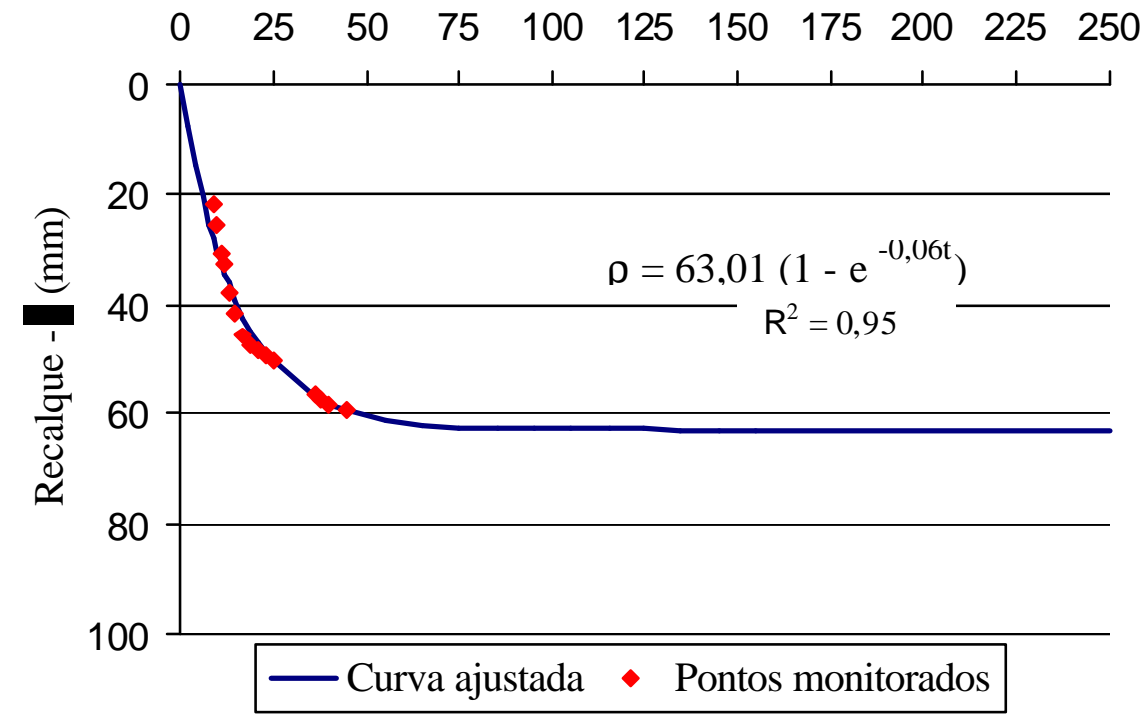

Figura 6.17 - S14 (Vale Verzasca): pontos monitorados e curva ajustada 
S11 Maison Elizabeth

Tempo de construção - $\mathrm{t}$ (meses)

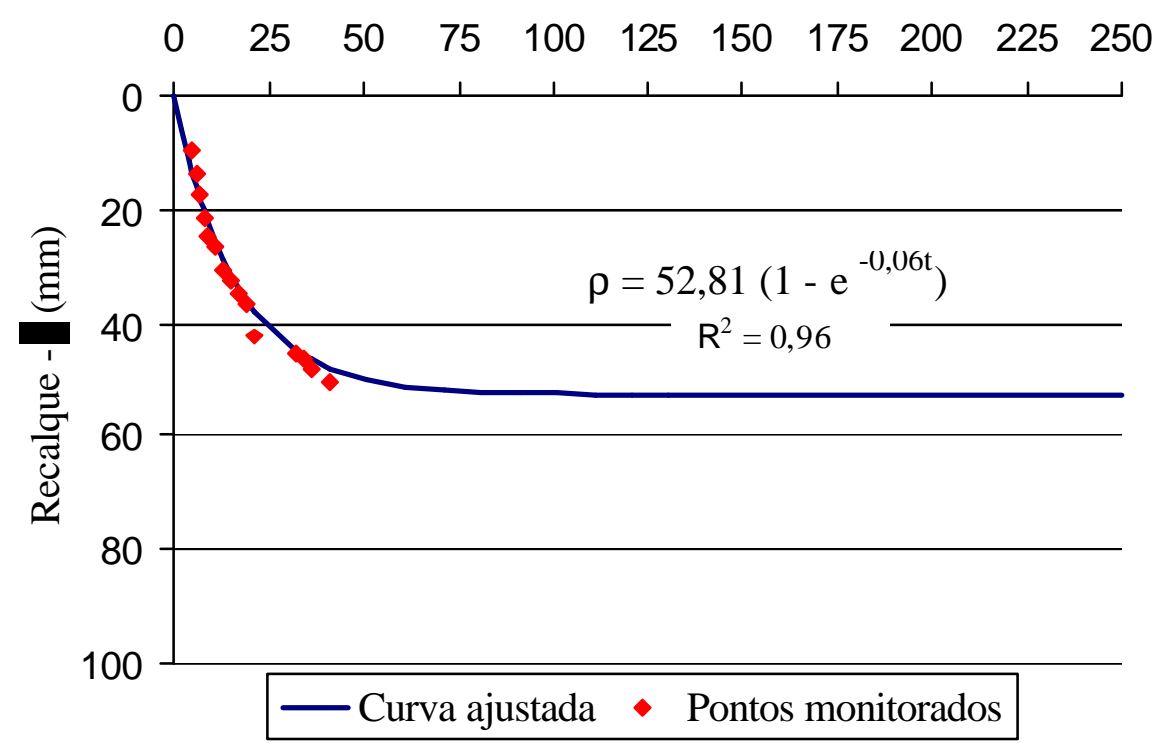

Figura 6.18 - S11 (Maison Elizabeth): pontos monitorados e curva ajustada

S17 Maison Elizabeth

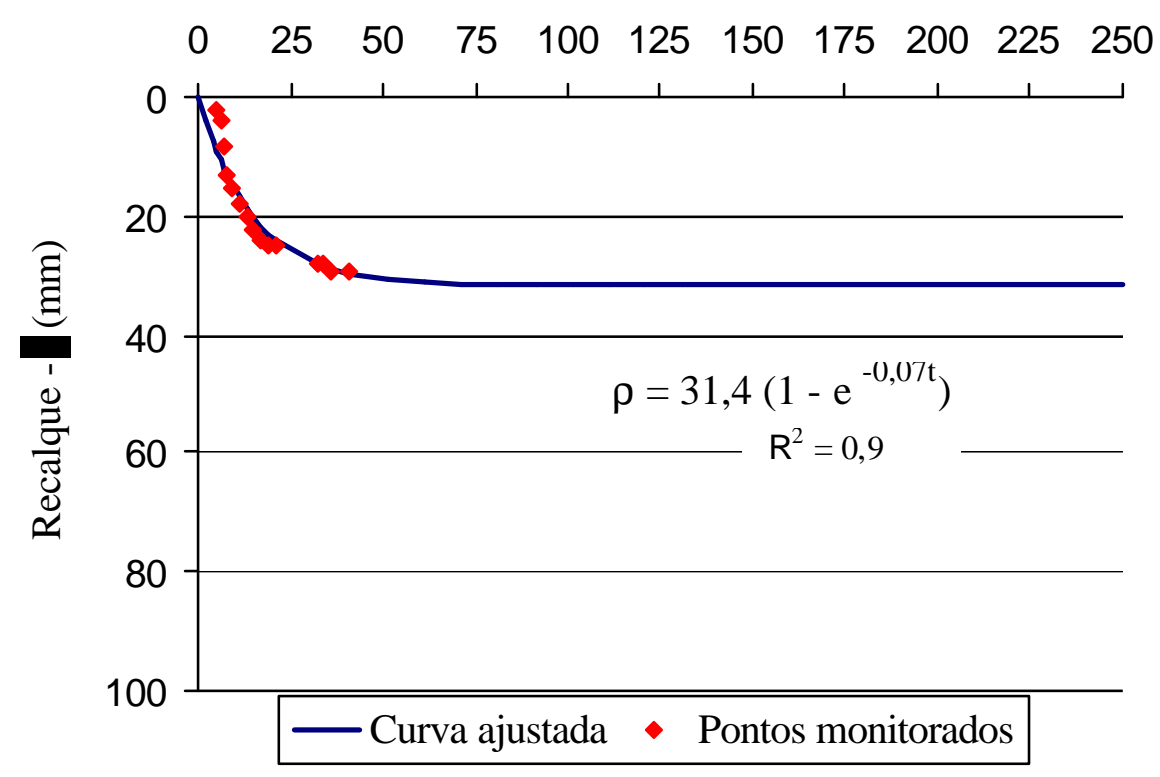

Figura 6.19 - S17 (Maison Elizabeth): pontos monitorados e curva ajustada 
S20 Maison Elizabeth

Tempo de construção - $\mathrm{t}$ (meses)

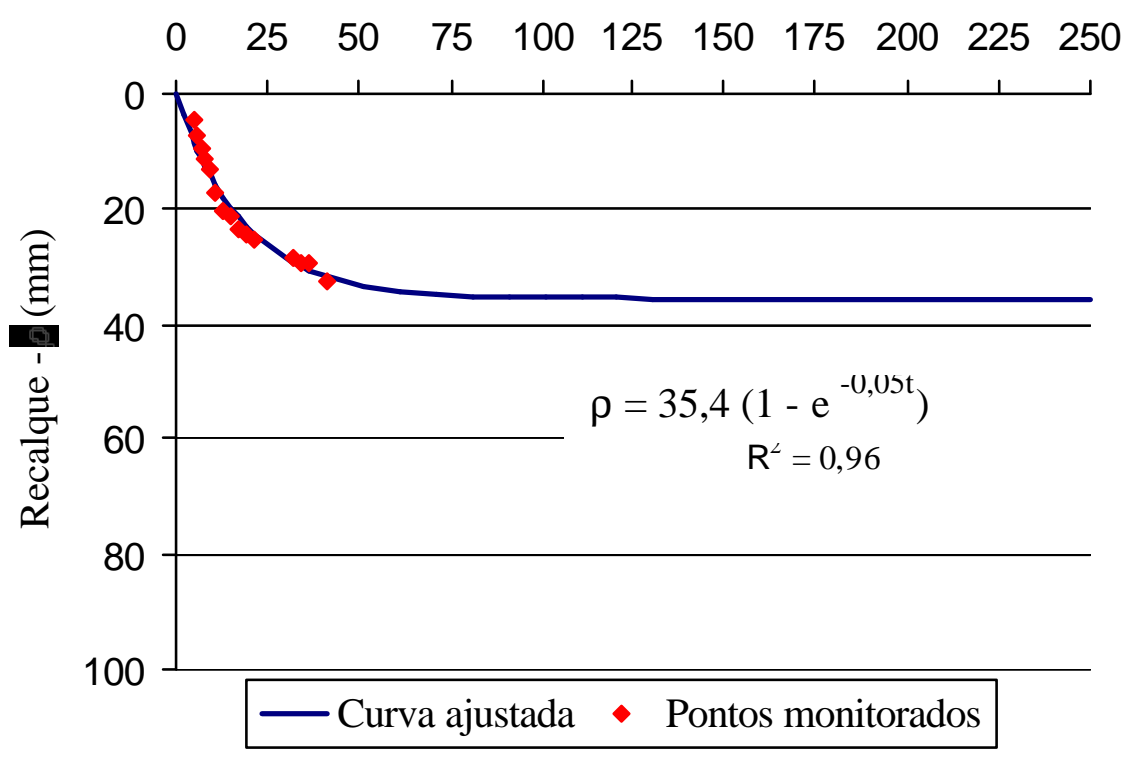

Figura 6.20 - S20 (Maison Elizabeth): pontos monitorados e curva ajustada

As tabelas 6.3 a 6.5 mostram os valores dos recalques obtidos com o ajuste à expressão adaptada de Massad (1982): o recalque inferido $\Delta$, ocorrido antes do monitoramento, o recalque no final de construção e o recalque estabilizado $\rho_{\text {est }}$.

Tabela 6.1 - Maison des Princes: recalques obtidos com o ajuste

\begin{tabular}{cccc}
\hline \multirow{2}{*}{ Maison des princes } & \multicolumn{3}{c}{ Recalque (mm) } \\
\cline { 2 - 4 } & \multicolumn{3}{c}{ Sapata } \\
\cline { 2 - 4 } & S6 & S8 & S13 \\
\hline Inferido $(\Delta)$ & 16 & 25 & 27 \\
\hline Final da construção & 52 & 68 & 68 \\
\hline Estabilizado $\left(\rho_{\text {est }}\right)$ & 62 & 75 & 75 \\
\hline
\end{tabular}


Tabela 6.2 - Vale Verzasca: recalques obtidos com o ajuste

\begin{tabular}{cccc}
\hline \multirow{2}{*}{ Vale Verzasca } & \multicolumn{3}{c}{ Recalque $(\mathbf{m m})$} \\
\cline { 2 - 4 } & \multicolumn{3}{c}{ Sapata } \\
\cline { 2 - 4 } & $\mathrm{S} 2$ & $\mathrm{~S} 3$ & $\mathrm{~S} 14$ \\
\hline Inferido $(\Delta)$ & 8 & 11 & 22 \\
\hline Final da construção & 35 & 39 & 57 \\
\hline Estabilizado $\left(\rho_{\text {est }}\right)$ & 87 & 57 & 63 \\
\hline
\end{tabular}

Tabela 6.3- Maison Elizabeth: recalques obtidos com o ajuste

\begin{tabular}{cccc}
\hline \multirow{2}{*}{ Maison Elizabeth } & \multicolumn{3}{c}{ Recalque (mm) } \\
\cline { 2 - 4 } & \multicolumn{3}{c}{ Sapata } \\
\cline { 2 - 4 } & S11 & S17 & S20 \\
\hline Inferido $(\Delta)$ & 10 & 2 & 4 \\
\hline Final da construção & 51 & 29 & 32 \\
\hline Estabilizado $\left(\rho_{\text {est }}\right)$ & 53 & 31 & 35 \\
\hline
\end{tabular}

Considerando a hipótese de ocorrência dos recalques extrapolados, alguns valores podem ser considerados bastante expressivos, uma vez que ultrapassam os indicados como admissíveis na literatura. Porém, cabe lembrar que Gusmão et al. (2000) obtiveram recalques medidos variando entre 84 a $105 \mathrm{~mm}$, com "desempenho satisfatório da fundação até o momento, onde não foram observados quaisquer danos que pudessem ser atribuídos a movimentos da fundação, apesar da magnitude dos recalques absolutos”. 
As sapatas adjacentes S2 e S3 do Vale Verzasca apresentariam um recalque diferencial de $20 \mathrm{~mm}$, o mesmo valor sugerido por Terzaghi \& Peck (1967) como recalque diferencial admissível. O recalque diferencial específico entre as duas seria de $1 / 271$, pouco maior que o valor limite proposto por Skempton-MacDonald.

Em análise separada, foi feito, novamente, o ajuste das curvas tempo x recalque das sapatas S2 e S3 do Vale Verzasca. Desprezaram-se dois pontos de cada curva, correspondentes a $\mathrm{t}=36$ e $\mathrm{t}=38$ meses de construção. Observourse uma melhora na regressão, mostrada nas Figuras 6.21 e 6.22, em que se pode conferir o aumento do coeficiente de correlação $\left(\mathrm{R}^{2}\right)$. Esta nova regressão se refere às sapatas como S2a e S3a.

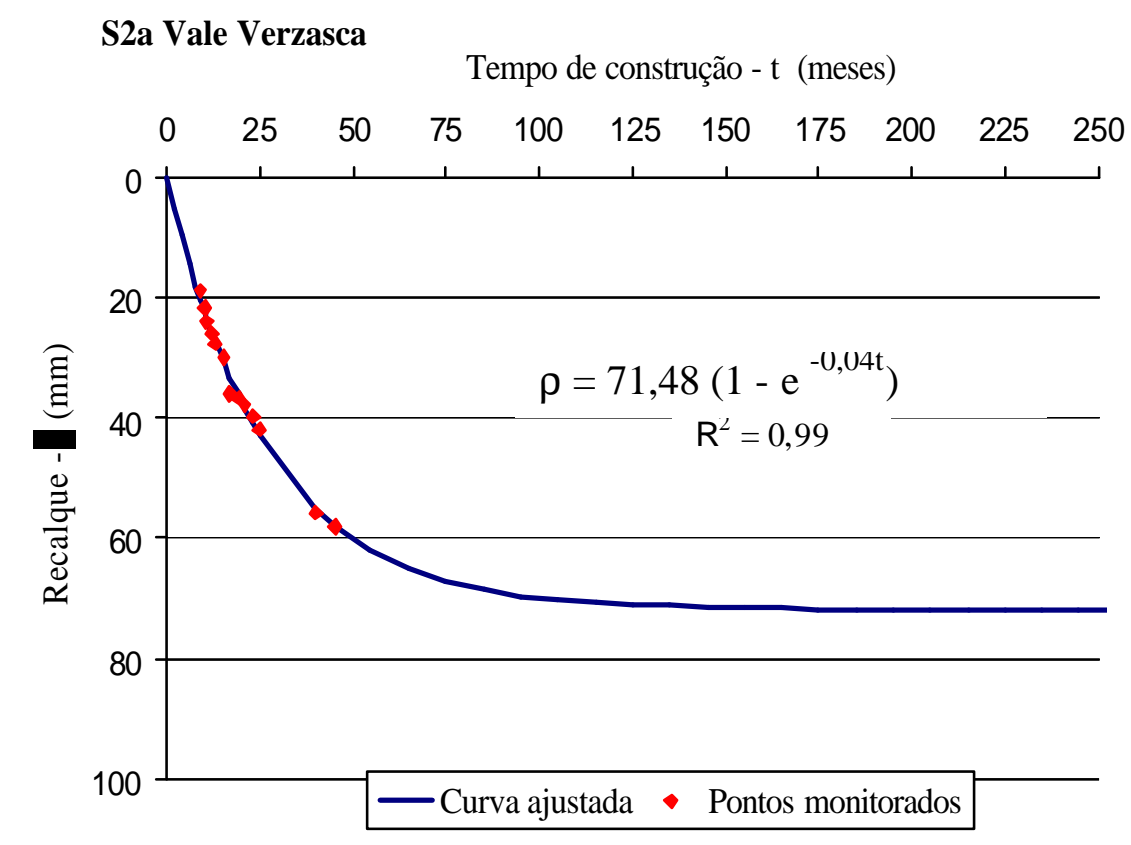

Figura 6.21 - S2a (Vale Verzasca): pontos monitorados e curva ajustada 


\section{S3a Vale Verzasca}

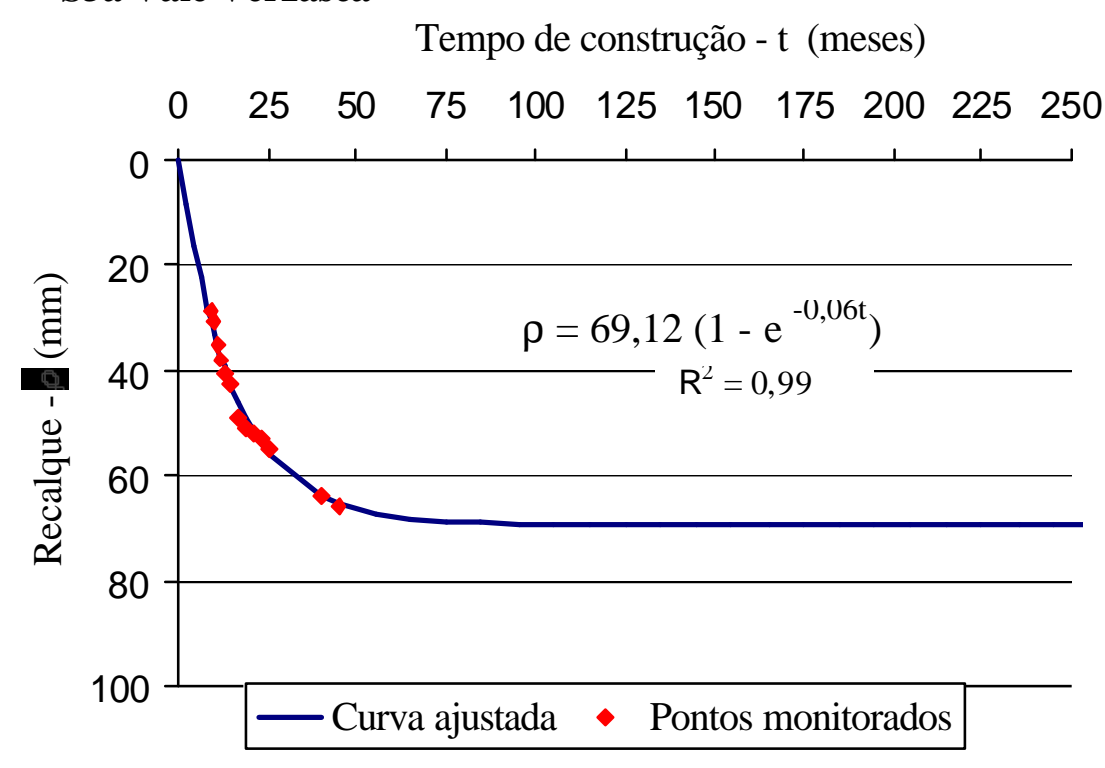

Figura 6.22 - S3a (Vale Verzasca): pontos monitorados e curva ajustada

A tabela 6.6 mostra os valores dos recalques obtidos com o novo ajuste.

Tabela 6.4 - Vale Verzasca: recalques obtidos com novo ajuste

\begin{tabular}{ccc}
\hline \multirow{2}{*}{ Vale Verzasca } & \multicolumn{2}{c}{ Recalque } \\
\cline { 2 - 3 } & \multicolumn{2}{c}{ Sapata } \\
\cline { 2 - 3 } & S2a & S3a \\
\hline Inferido $(\Delta)$ & 19 & 29 \\
\hline Final da construção & 46 & 57 \\
\hline Estabilizado $\left(\rho_{\text {est }}\right)$ & 72 & 69 \\
\hline
\end{tabular}

Tais valores resultariam num recalque diferencial de $3 \mathrm{~mm}$ e recalque diferencial específico de 1/1808, bastante menores que os indicados por Terzaghi \& Peck (1967) (20 $\mathrm{mm})$ e Skempton-MacDonald (1/300). 
Considerando os recalques obtidos para o período em que não houve monitoramento, as velocidades médias de recalque correspondentes seriam as mostradas na Tabela 6.7 .

Tabela 6.5 - Velocidades de recalque obtidas para o período sem monitoramento

\begin{tabular}{|c|c|c|}
\hline Edifício & Sapata & Velocidade de recalque* \\
\hline \multirow[t]{3}{*}{ Maison des princes } & S6 & $53 \mu \mathrm{m} / \mathrm{dia}$ \\
\hline & S8 & $83 \mu \mathrm{m} / \mathrm{dia}$ \\
\hline & S13 & $90 \mu \mathrm{m} / \mathrm{dia}$ \\
\hline \multirow[t]{5}{*}{ Vale Verzasca } & $\mathrm{S} 2$ & $30 \mu \mathrm{m} / \mathrm{dia}$ \\
\hline & $\mathrm{S} 2 \mathrm{a}$ & $70 \mu \mathrm{m} / \mathrm{dia}$ \\
\hline & $\mathrm{S} 3$ & $41 \mu \mathrm{m} / \mathrm{dia}$ \\
\hline & $\mathrm{S} 3 \mathrm{a}$ & $107 \mu \mathrm{m} / \mathrm{dia}$ \\
\hline & $\mathrm{S} 14$ & $81 \mu \mathrm{m} / \mathrm{dia}$ \\
\hline \multirow[t]{3}{*}{ Maison Elizabeth } & S11 & $67 \mu \mathrm{m} /$ dia \\
\hline & $\mathrm{S} 17$ & $13 \mu \mathrm{m} / \mathrm{dia}$ \\
\hline & $\mathrm{S} 20$ & $27 \mu \mathrm{m} / \mathrm{dia}$ \\
\hline
\end{tabular}

Velocidade de recalque*: velocidade média de recalque obtida por meio das regressões e correspondente ao período de desde o início das construções ao início do monitoramento.

As velocidades obtidas não se mostraram muito diferentes, para os mesmos carregamentos, das observadas nos monitoramentos dos edifícios Boulevard Manaíra e Stéphano. Isso contribuiria para uma possível validação da opção pela regressão e extrapolação das curvas tempo x recalque medidas.

Schmertmann (1970) adotou o fator de correção $C_{2}$ no seu procedimento para estimativas de recalques em areias, para a consideração do efeito do tempo, definido por:

$$
\mathrm{C}_{2}=1+0,2 \log \left(\frac{\mathrm{t}}{0,1}\right)
$$

em que $\mathrm{t}=$ tempo em anos. 
A última parte da expressão, 0,2 $\log (\mathrm{t} / 0,1)$, representa, então, o acréscimo de recalque ocorrido após o imediato, em relação a este.

Levando-se em conta os recalques obtidos com a extrapolação para antes do monitoramento e correspondente aos que teriam ocorrido a partir do começo das obras, podem-se obter os recalques sofridos pelas sapatas desde o início até o fim de cada construção.

Considerando esse recalque como imediato, uma vez que é o ocorrido durante a aplicação da carga, e a partir dos recalques medidos nos casos em que ainda houve monitoramento após o término da obra, calcularam-se os acréscimos de recalque, em termos percentuais, em relação ao imediato. Estes são comparados aos valores indicados por Schmertmann (1970) por meio do fator tempo $\mathrm{C}_{2}$, e mostrados na Tabela 6.8 e na Figura 6.23.

Tabela 6.6 - Acréscimos de recalque após o término da construção

\begin{tabular}{|c|c|c|c|c|}
\hline \multirow{3}{*}{ Edifício } & \multirow{3}{*}{ Sapata } & \multicolumn{3}{|c|}{ Acréscimo } \\
\hline & & \multicolumn{3}{|c|}{ Tempo após ocorrência do recalque imediato (meses) } \\
\hline & & 2 & 3 & 8 \\
\hline \multirow[t]{3}{*}{ M. Princes } & S6 & $2 \%$ & - & - \\
\hline & S8 & $1 \%$ & - & - \\
\hline & S13 & $1 \%$ & - & - \\
\hline \multirow[t]{3}{*}{ V. Verzasca } & $\mathrm{S} 2$ & - & $26 \%$ & $31 \%$ \\
\hline & S3 & - & $13 \%$ & $17 \%$ \\
\hline & $\mathrm{S} 14$ & - & $2 \%$ & $4 \%$ \\
\hline Média & & $2 \%$ & $14 \%$ & $17 \%$ \\
\hline \multirow[t]{3}{*}{ V.Verzasca $(\mathrm{S} 2 \mathrm{a}, \mathrm{S} 3 \mathrm{a})$} & $\mathrm{S} 2 \mathrm{a}$ & - & $19 \%$ & $23 \%$ \\
\hline & $\mathrm{S} 3 \mathrm{a}$ & - & $12 \%$ & $16 \%$ \\
\hline & $\mathrm{S} 14$ & - & $2 \%$ & $4 \%$ \\
\hline Média & & - & $12 \%$ & $15 \%$ \\
\hline Schmertmann (1970) & & $4 \%$ & $8 \%$ & $17 \%$ \\
\hline
\end{tabular}




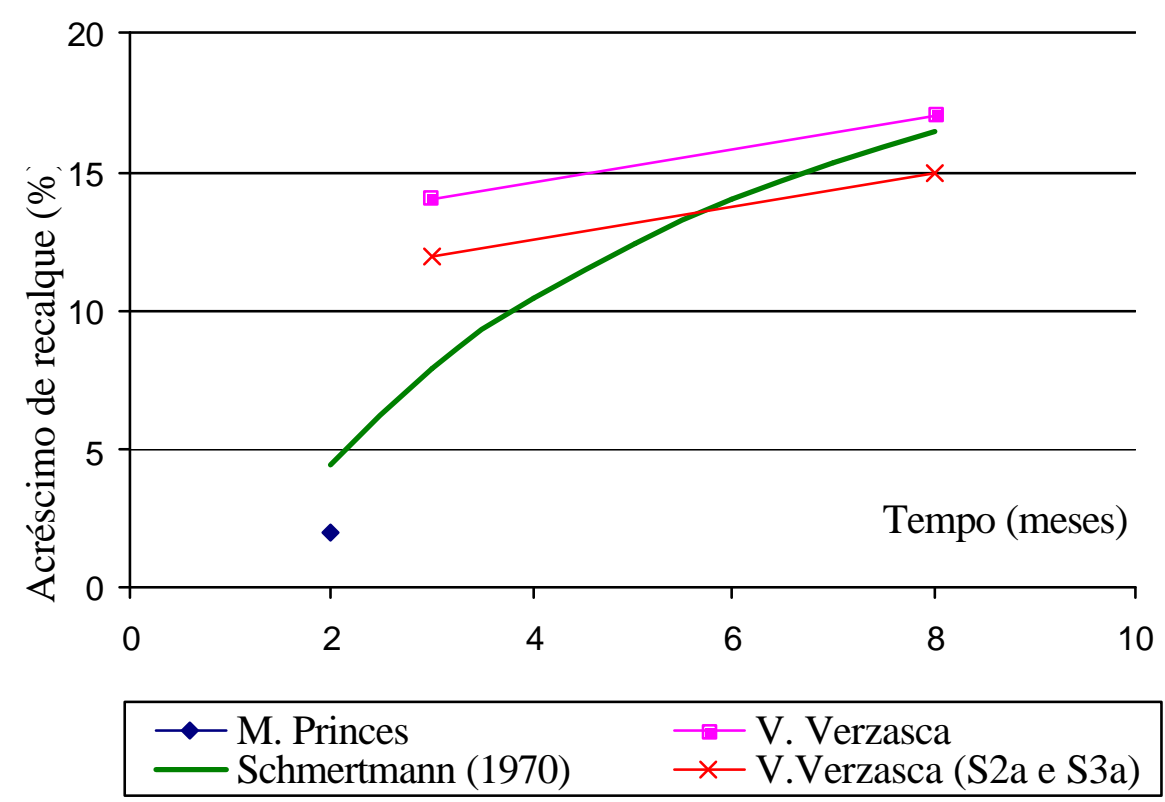

Figura 6.23 - Acréscimos de recalque em relação ao imediato

\subsection{Estimativas}

\subsubsection{Módulo de Deformabilidade}

Observaram-se aumentos nos valores do módulo de deformabilidade em função de $\mathrm{N}_{\text {SPT }}$ após a compactação do solo, havendo um caso em que o módulo do solo compactado atingiu sete vezes o valor do módulo do solo natural (primeira camada sob o edifício Maison des Princes). Nos casos em que as sondagens SPT pós-compactação persistiram até profundidades além das camadas compactadas, os dos solos subjacentes ao Maison des Princes e Vale Verzasca, verificou-se que as diferenças de valores entre o módulo do solo compactado e natural diminuem a partir da profundidade de $8 \mathrm{~m}$. 


\subsubsection{Indeformável}

Nas estimativas de recalques, o indeformável foi considerado como sendo os limites das sondagens disponíveis, e obtiveram-se as parcelas de recalque correspondentes a cada camada de solo. As Figuras 6.24 a 6.28 mostram os recalques médios totais estimados de cada camada de solo subjacente aos edifícios aqui analisados, para as situações de solo natural e compactado.

\section{Maison des Princes}

Recalque médio das camadas (mm)

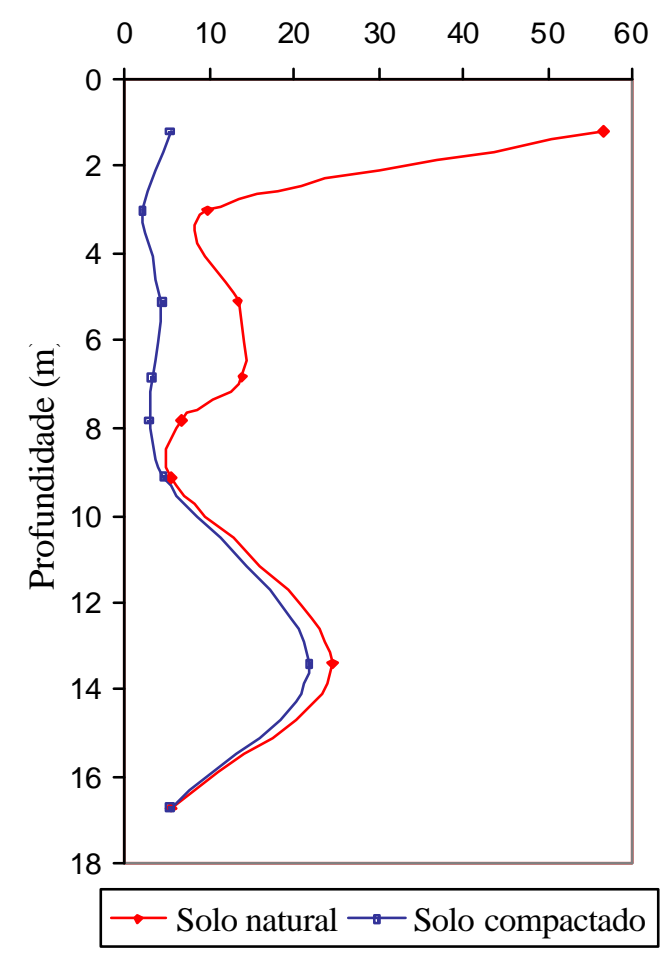

Figura 6.24 - Maison des Princes: recalques médios totais estimados de cada camada de solo subjacente natural e compactado 


\section{Vale Verzasca}

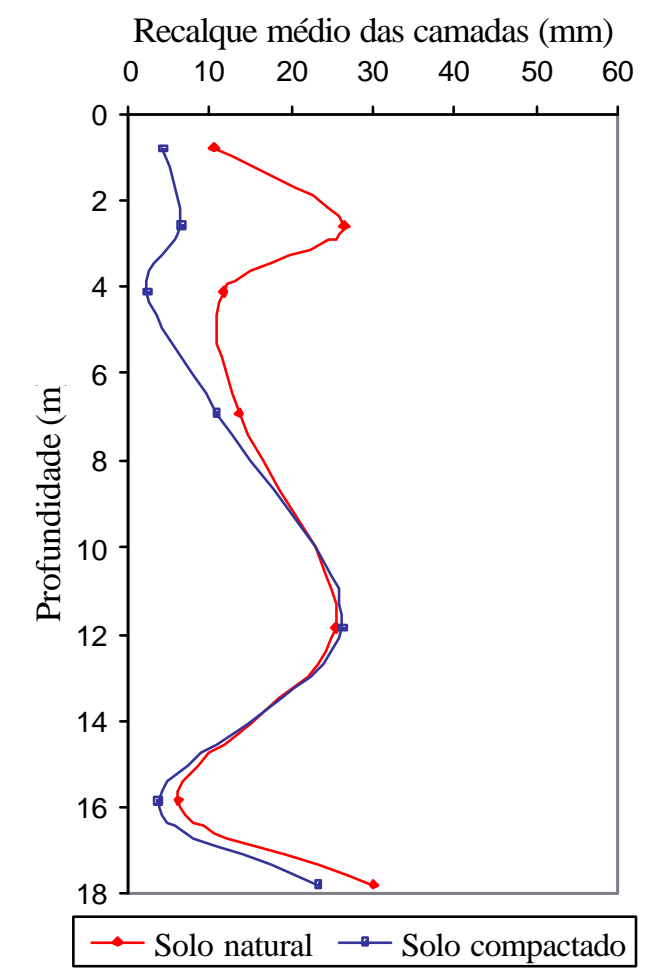

Figura 6.25 - Vale Verzasca: recalques médios totais estimados de cada camada de solo subjacente natural e compactado

\section{Maison Elizabeth}

Recalque médio das camadas $(\mathrm{mm})$

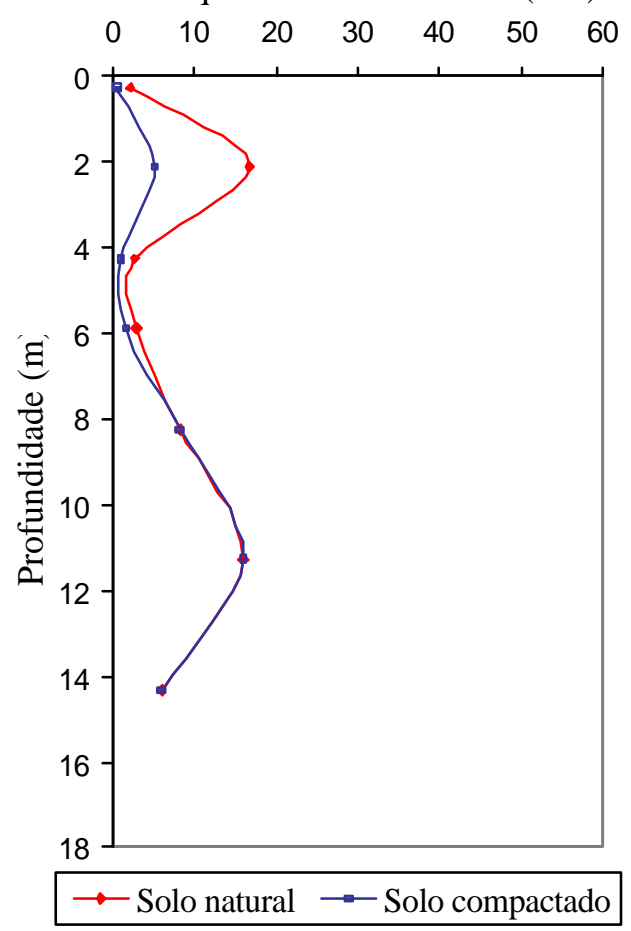

Figura 6.26 - Maison Elizabeth: recalques médios totais estimados de cada camada de solo subjacente natural e compactado 


\section{Boulevard Manaíra}

Recalque médio das camadas ( $\mathrm{mm}$ )

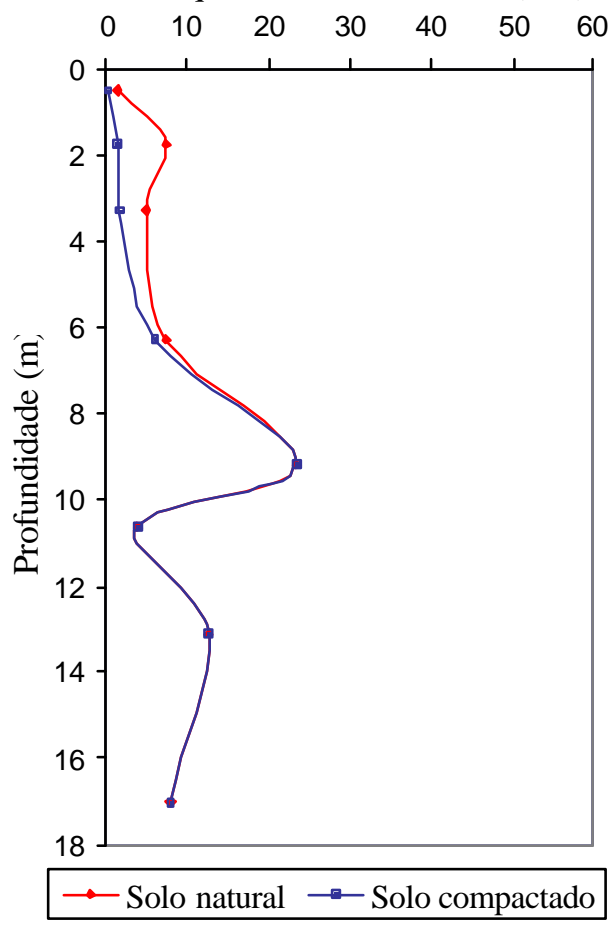

Figura 6.27 - Boulevard Manaíra: recalques médios totais estimados de cada camada de solo subjacente natural e compactado

\section{Stéphano}

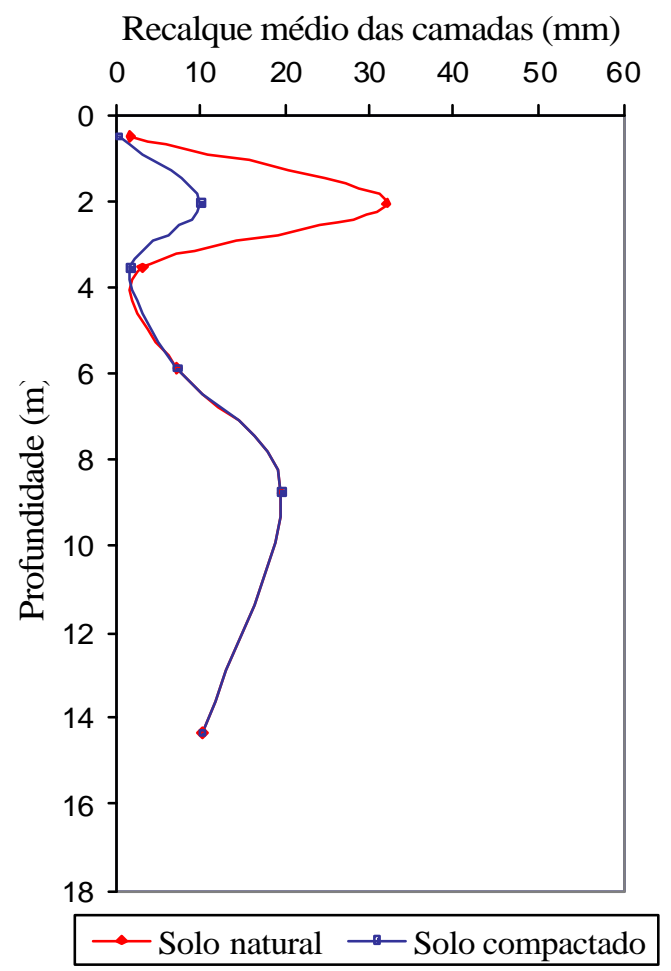

Figura 6.28 - Stéphano: recalques médios totais estimados de cada camada de solo subjacente natural e compactado 


\subsubsection{Recalques totais}

A maior redução média de recalques estimados entre sapatas obtida foi de $63 \%$, referente ao edifício Maison des Princes, cujo solo contém as estacas com menor espaçamento $(80 \mathrm{~cm})$ e maior profundidade $(5 \mathrm{~m})$ dentro da área de projeção das sapatas.

Os edifícios residenciais Vale Verzasca e Maison Elizabeth obtiveram reduções médias estimadas de 38 e $29 \%$, respectivamente.

Já o prédio Boulevard Manaíra apresentou uma redução média estimada de 18\%, enquanto o Stéphano obteve redução média estimada de $33 \%$.

As menores reduções estimadas obtidas foram nos casos em que os terrenos naturais dos edifícios eram mais compactos, o que torna o processo de compactação menos eficaz (Soares, 2002). Eles apresentavam alguns valores de $\mathrm{N}_{\mathrm{SPT}}$ maiores que 10 , com $\mathrm{N}_{\text {SPT }}$ médios de algumas camadas de solo natural ultrapassando o valor de 20.

Os recalques estimados para as sapatas centrais dos edifícios foram maiores que os das de extremidade, assim como as reduções estimadas para estas últimas foram maiores que as das primeiras, com exceção do Residencial Vale Verzasca. Neste caso, aparentemente, a localização das sapatas não promoveu diferenças consideráveis entre as reduções estimadas de recalque das centrais e de extremidade. Tal fato pode ser talvez explicado devido à carga de projeto da sapata de extremidade $\mathrm{S} 3$ ser relativamente alta em relação às outras, assim como a sapata também de extremidade S14 estar muito próxima a outras três sapatas, como pode ser visto no esquema do projeto de fundações do edifício no Capítulo 4 deste trabalho.

O Apêndice A exibe as saídas do programa com os recalques totais estimados.

Observou-se ainda que a despeito das reduções estimadas para os valores totais de recalque, as reduções de recalque estimado das camadas, individualmente, mostraram-se 
consideravelmente maiores para as camadas mais superficiais. A Tabela 6.9 exibe as reduções médias de recalque estimado para cada camada de solo sob os edifícios analisados.

Tabela 6.7 - Reduções de recalque médio estimado para as camadas

\begin{tabular}{cccccc}
\hline & \multicolumn{5}{c}{ Redução de recalque estimado médio (\%) } \\
\cline { 2 - 6 } Camada* & \multicolumn{5}{c}{ Edifício } \\
\cline { 2 - 6 } & M. princes & V. Verzasca & M. Elizabeth & $\begin{array}{c}\text { Boulevard } \\
\text { Manaíra }\end{array}$ & Stéphano \\
\hline 1 & 90 & 62 & 81 & 84 & 83 \\
\hline 2 & 79 & 76 & 69 & 81 & 69 \\
\hline 3 & 68 & 82 & 60 & 68 & 49 \\
\hline 4 & 76 & 21 & 45 & 20 & 4 \\
\hline 5 & 55 & 6 & 2 & 0 & 0 \\
\hline 6 & 15 & 38 & 0 & 0 & 0 \\
\hline 7 & 10 & 23 & 3 & 6 & \\
\hline 8 & 0 & & & 0 & \\
\hline 9 & & & & 0 & \\
\hline
\end{tabular}

*Ordem das camadas crescente da mais próxima da superfície a mais profunda.

\subsection{Retroanálise do módulo}

Considerando a hipótese de ocorrência dos recalques extrapolados, estes foram usados na retroanálise do módulo adotado. Para tanto, também se utilizaram os valores estimados de recalque total, dos caso de solo compactado dos edifícios Maison des Princes, Vale Verzasca e Maison Elizabeth.

A Tabela 6.10 mostra os valores de recalque das sapatas, em solo compactado, obtidos com o monitoramento e extrapolações, assim como os estimados pelo método Aoki - Lopes para as mesmas. 
Tabela 6.8 - Recalques estimados e obtidos com o monitoramento e extrapolações

\begin{tabular}{lccc}
\hline \multirow{2}{*}{ Edifício } & \multirow{2}{*}{ Sapata } & \multicolumn{3}{c}{ Solo compactado } \\
\cline { 2 - 4 } & & Recalque obtido (mm) & Recalque estimado (mm) \\
\hline M. Princes & 6 & 62 & 30 \\
\hline & 8 & 75 & 60 \\
\hline V.Verzasca & 13 & 75 & 78 \\
\hline & 2 & 87 & 59 \\
\hline & 3 & 57 & 71 \\
\hline & 14 & 63 & 72 \\
\hline & $2 \mathrm{a}$ & 72 & 59 \\
\hline M. Elizabeth & $3 \mathrm{a}$ & 69 & 54 \\
\hline & 11 & 53 & 27 \\
\hline & 17 & 31 & 24 \\
\hline
\end{tabular}

Comparando-se os valores, observam-se os efeitos da redistribuição de cargas devido a interação estrutura-solo. As sapatas de extremidade apresentaram recalques obtidos maiores que os estimados, sugerindo a atuação de sobrecarga influenciada pela rigidez da estrutura. Como exceção, a sapata de extremidade S3 do Vale Verzasca exibiu um recalque obtido menor que o estimado, provavelmente porque possuía carga de projeto relativamente maior que a maioria das outras. Os recalques obtidos para as sapatas centrais foram menores que os estimados, evidenciando alívio de carga.

A partir dos valores estimados e obtidos pelo monitoramento e extrapolações, foi feita a correção do módulo de deformabilidade adotado. As Figuras 6.29 a 6.30 mostram o módulo corrigido $\left(\mathrm{E}_{\mathrm{S}}\right)$ para solo natural e compactado de cada edifício. 


\section{Maison des Princes}

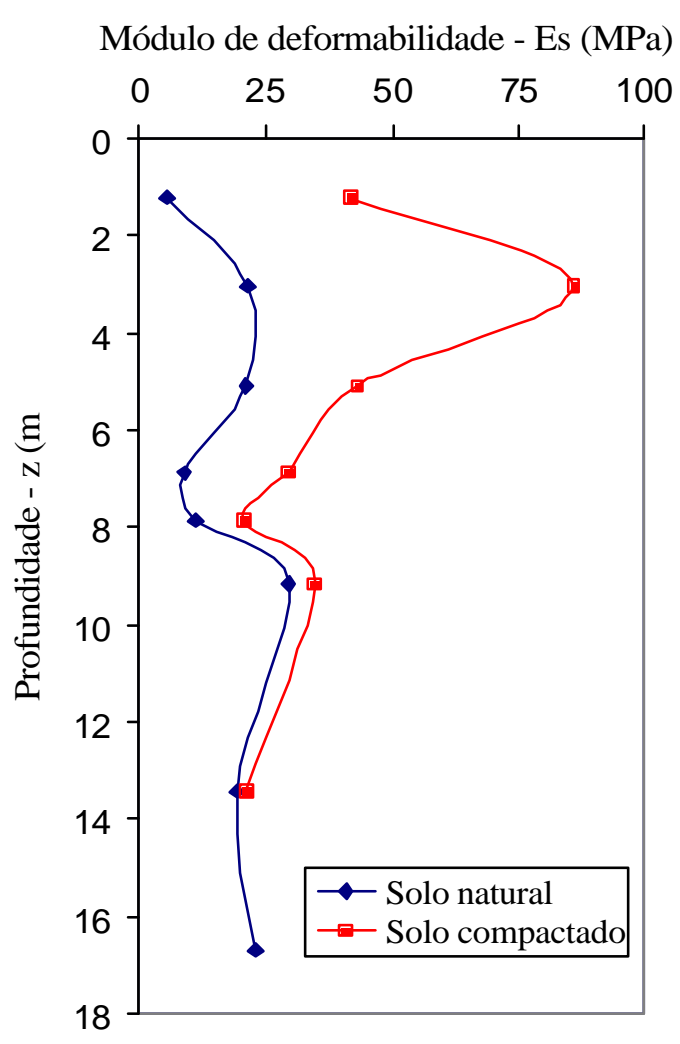

Figura 6.28 - Maison des Princes: Gráfico de $E_{S}$ x z para solo natural e compactado

\section{Vale Verzasca}

Módulo de deformabilidade - Es (MPa)

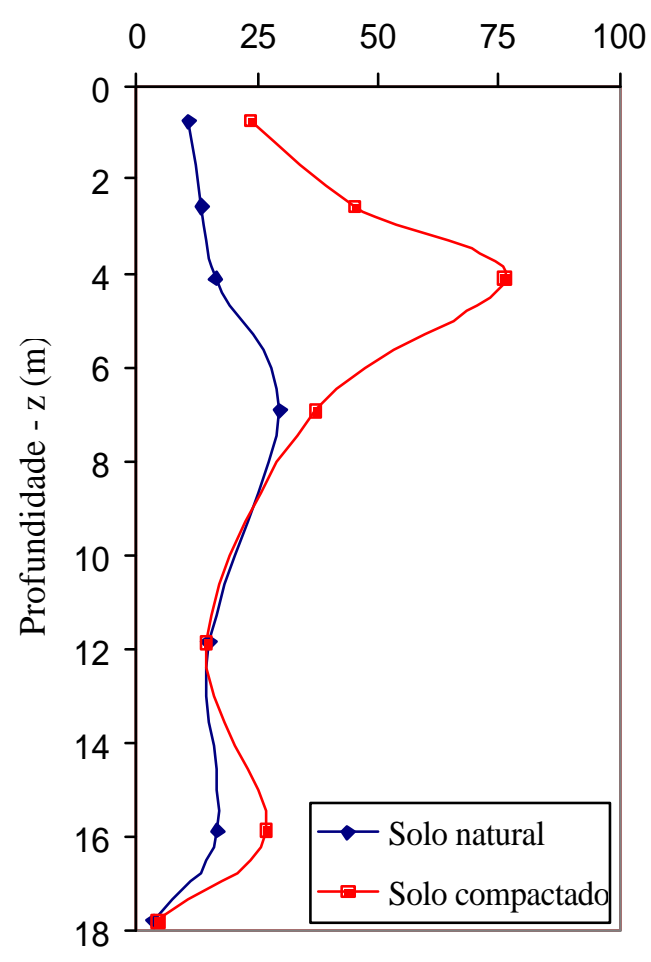

Figura 6.29 - Vale Verzasca: Gráfico de $\mathrm{E}_{\mathrm{S}}$ x z para solo natural e compactado 


\section{Maison Elizabeth}

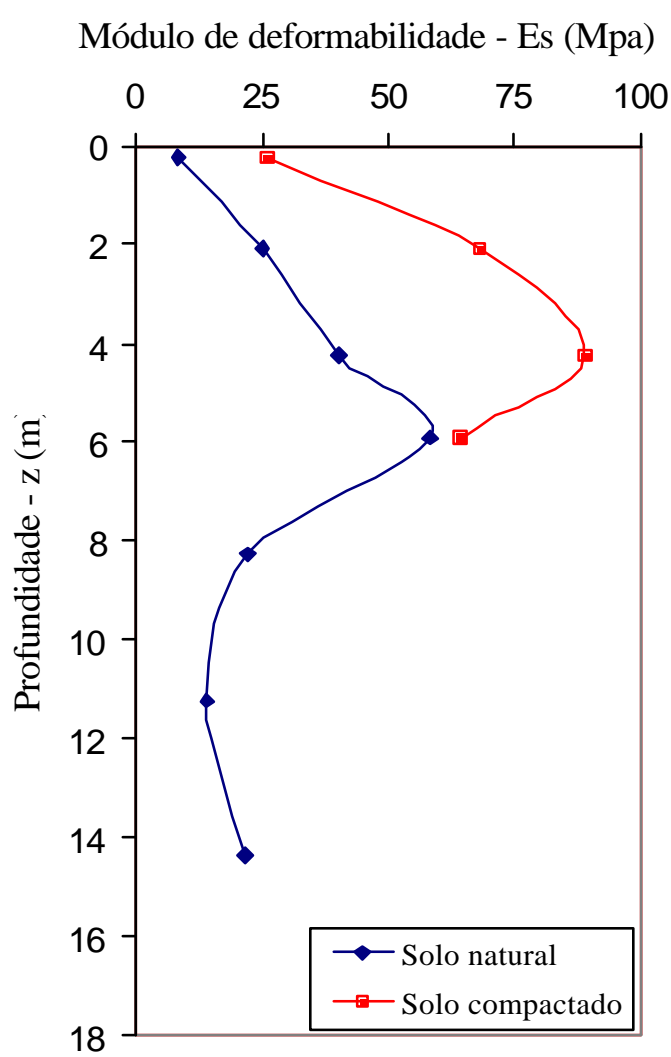

Figura 6.30 - Maison Elizabeth: Gráfico de $\mathrm{E}_{\mathrm{S}}$ x z para solo natural e compactado

Para o solo melhorado, os valores do módulo corrigido das camadas próximas à superfície não se mostraram muito diferentes dos valores de módulo sugerido por Alves et al. (2000). Os autores propõem a correlação $\mathrm{E}=\mathrm{a} N_{S P T}$, em que a é um coeficiente que varia com o tipo de solo. Apresentam também ábacos que fornecem o módulo da camada equivalente (solo + estacas). O valor deste, porém, não se mostrou próximo ao do módulo corrigido. A Tabela 6.11 mostra os valores do módulo corrigido e do calculado pela correlação e ábacos de Alves et al. (2000). 
Tabela 6.9- Módulo corrigido e calculado pela correlação e ábacos de Alves et al. (2000).

\begin{tabular}{ccccc}
\hline Edifício & Camada de solo & $\mathbf{E}_{\mathbf{s}}(\mathbf{M P a})$ & $\mathbf{E}_{\mathbf{s o l o}}{ }^{*}(\mathbf{M P a})$ & $\mathbf{E}_{\mathbf{e q}}{ }^{*}$ \\
\hline M. Princes & 1 & 42 & 53 & 92 \\
\hline & 2 & 86 & 79 & 115 \\
\hline Vale Verzasca & 3 & 43 & 68 & 110 \\
\hline & 1 & 24 & 25 & 70 \\
\hline M. Elizabeth & 2 & 45 & 57 & 100 \\
\hline & 3 & 76 & 45 & 85 \\
\hline & 2 & 26 & 28 & 75 \\
\hline
\end{tabular}

* $\mathrm{E}_{\text {solo }}$ : - módulo do terreno melhorado, da correlação de Alves et. al.(2000).

* $\mathrm{E}_{\mathrm{eq}}$ : - módulo da camada equivalente a partir do ábaco de Alves et. al.(2000).

Cabe lembrar que na situação analisada por Alves et al. (2000) não foi levado em consideração o efeito de grupo, e os resultados foram obtidos por meio de prova de carga em placa.

\subsection{Redução}

Com o módulo corrigido do solo natural, estimaram-se novamente os recalques dos edifícios para a situação sem melhoria. As Tabelas 6.12 a 6.14 exibem estes valores juntamente com os obtidos com o monitoramento e extrapolações, e as Figuras 6.31 a 6.34 mostram as reduções entre os recalques dos dois casos. 
Tabela 6.10 - Maison des Princes: recalques estimados para o solo natural e obtidos com o monitoramento e extrapolações

\begin{tabular}{ccc}
\hline \multicolumn{3}{c}{ Maison des Princes } \\
\hline Sapata & $\begin{array}{c}\text { r solo } \\
\text { natural }(\mathrm{mm})\end{array}$ & $\begin{array}{c}\text { r obtido p/ solo } \\
\text { compactado (mm) }\end{array}$ \\
\hline S6 & 111 & 62 \\
\hline S8 & 205 & 75 \\
\hline S13 & 238 & 75 \\
\hline
\end{tabular}

Tabela 6.11 - Vale Verzasca: recalques estimados para o solo natural e obtidos com o monitoramento e extrapolações

\begin{tabular}{ccc}
\hline \multicolumn{3}{c}{ Vale Verzasca } \\
\hline Sapata & $\begin{array}{c}\text { r solo } \\
\text { natural }(\mathrm{mm})\end{array}$ & $\begin{array}{c}\text { r obtido p/ solo } \\
\text { compactado (mm) }\end{array}$ \\
\hline S2 & 119 & 87 \\
\hline S3 & 154 & 57 \\
\hline S14 & 148 & 63 \\
\hline S2a & & 72 \\
\hline S3a & & 69 \\
\hline
\end{tabular}

Tabela 6.12- Maison Elizabeth: recalques estimados para o solo natural e obtidos com o monitoramento e extrapolações

\begin{tabular}{ccc}
\hline \multicolumn{3}{c}{ Maison Elizabeth } \\
\hline Sapata & $\begin{array}{c}\text { r solo } \\
\text { natural }(\mathrm{mm})\end{array}$ & $\begin{array}{c}\text { r obtido p/ solo } \\
\text { compactado (mm) }\end{array}$ \\
\hline S11 & 87 & 53 \\
\hline S17 & 50 & 31 \\
\hline S20 & 44 & 35 \\
\hline
\end{tabular}




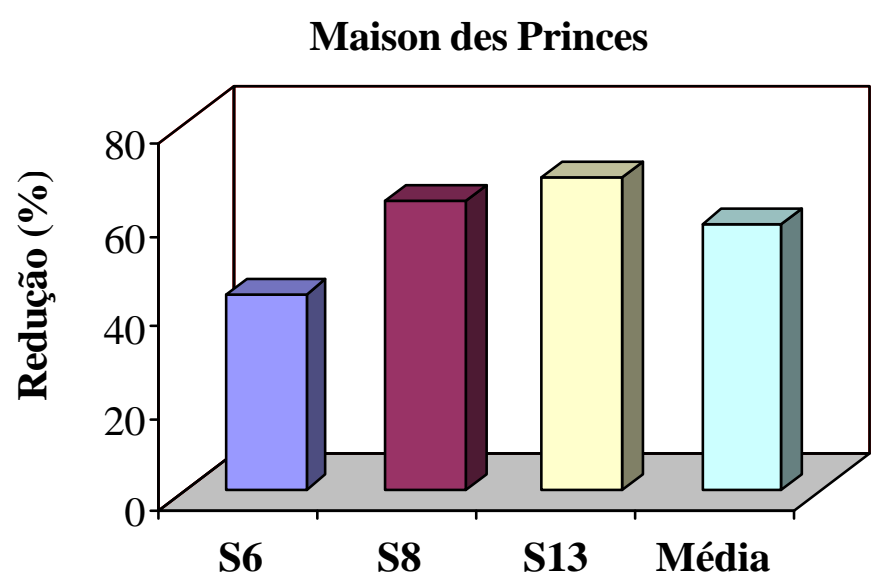

Figura 6.31 - Maison des Princes: Redução de recalques entre solo natural e compactado

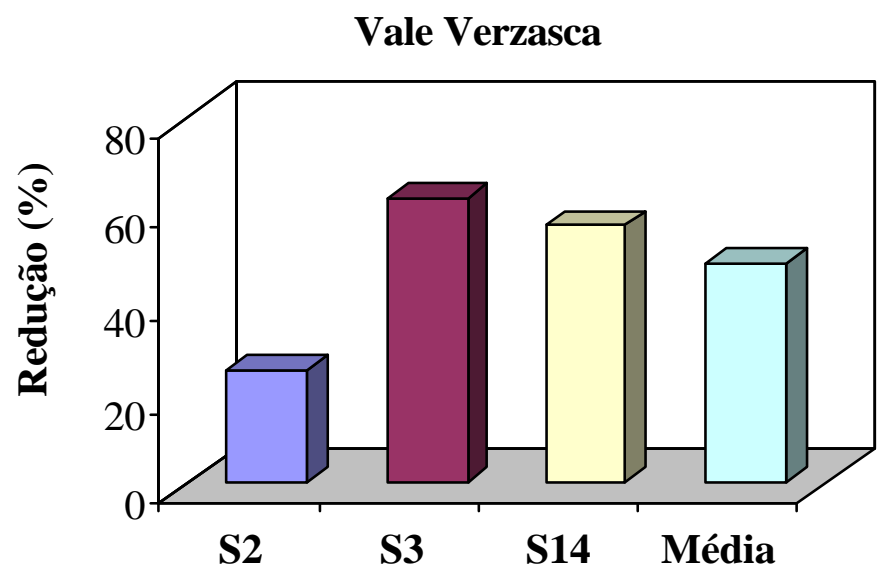

Figura 6.32 - Vale Verzasca: Redução de recalques entre solo natural e compactado

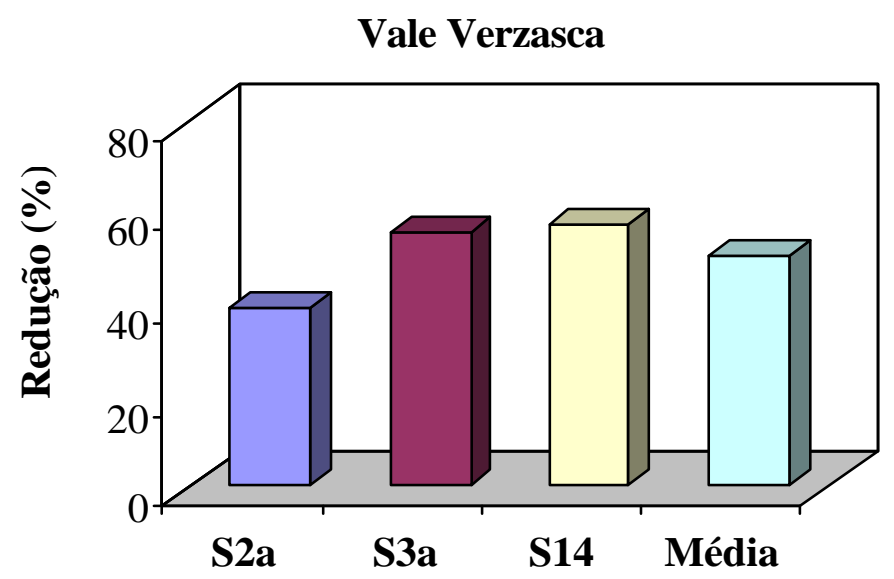

Figura 6.33 - Vale Verzasca: Redução de recalques entre solo natural e compactado (com S2a e S3a) 


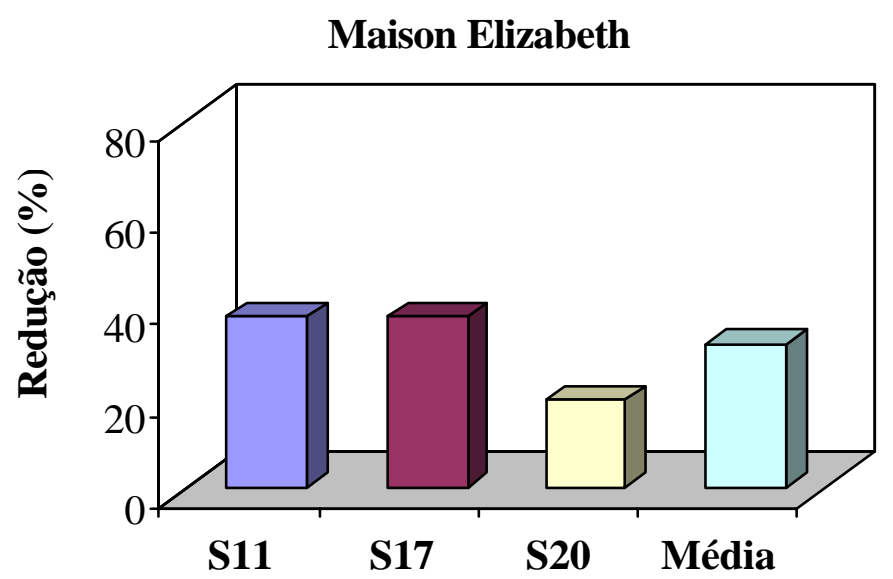

Figura 6.34 - Maison Elizabeth: Redução de recalques entre solo natural e compactado

Os recalques dos edifícios Maison des Princes e Vale Verzasca sofreram reduções em torno de 60 e $50 \%$, respectivamente. A primeira se mostrou próxima à redução de $64 \%$ estimada por Alves et al. (2000) para uma sapata sobre solo natural e solo melhorado.

Soares et. al (2003) apresentaram uma faixa de redução estimada para as duas situações de solo, variando de 41 a $72 \%$, de acordo com o tamanho das sapatas. Os autores utilizaram o método de Schmertmann (1970). Os prédios Residencial Vale Verzasca e Maison des Princes apresentaram reduções de recalque dentro desta faixa.

O Maison Elizabeth sofreu a menor redução média de recalques, cerca de 30\%. O seu terreno natural era mais compacto que o dos outros, o que torna o processo de compactação menos eficaz (Soares, 2002). Ele apresentava valores de $\mathrm{N}_{\text {SPT }}$ maiores que 10, com $\mathrm{N}_{\text {SPT }}$ médios de algumas camadas de solo natural ultrapassando o valor de 20. 


\section{Conclusão}

Foram analisados os recalques de cinco edifícios sobre solo melhorado com estacas de compactação, monitorados na cidade de João Pessoa - PB. Avaliourse a eficácia do processo de melhoria na redução do recalque dos prédios, através de recalques estimados e dos recalques obtidos com o monitoramento.

As estimativas foram feitas pelo método Aoki-Lopes, a partir de sondagens SPT obtidas antes e após compactação, que foram usadas na adoção do módulo de deformabilidade. Consideraram-se os casos de solo compactado e natural.

Observaram-se aumentos nos valores do módulo em função de $\mathrm{N}$ após a compactação do solo, havendo um caso em que o módulo do solo compactado atingiu sete vezes o valor do módulo do solo natural. Nos casos em que as sondagens SPT pós-compactação persistiram até 
profundidades além das camadas compactadas, verificourse que as diferenças de valores entre o módulo do solo compactado e natural diminuem a partir da profundidade de $8 \mathrm{~m}$.

Três dos edifícios, monitorados durante período que começou após o início das construções, apresentaram recalques das sapatas em torno de $40 \mathrm{~mm}$, sendo o maior de 44 mm. As únicas sapatas adjacentes incluídas no monitoramento apresentaram recalque diferencial de $2 \mathrm{~mm}$ e recalque diferencial específico de 1/2700. As velocidades não chegaram a ultrapassar a taxa de $200 \mu \mathrm{m} / \mathrm{dia}$, valor mencionado por Alonso (1991) como aceitável para construções sobre fundações diretas por sapatas.

Não foi observado nenhum tipo de dano relacionado a essa ordem de grandeza de recalque nos edifícios mencionados, mesmo decorrido mais de um ano da última leitura e do fim das construções.

Comparando-se os recalques estimados para a situação hipotética dos três edifícios em solo natural com os recalques obtidos por meio da extrapolação dos valores dos medidos, avaliou-se a redução de recalque entre os dois casos. Observaram-se reduções médias em torno de $60 \%$ e $50 \%$ para os edifícios Maison des Princes (com 30 pavimentos) e Vale Verzasca (com 26 pavimentos), respectivamente. O solo natural apresentava-se pouco compacto, com valores de $\mathrm{N}_{\mathrm{SPT}}$ menores que 10, o que favoreceu uma maior eficácia ao processo de melhoria.

A menor redução obtida foi de 33\%, referente ao Maison Elizabeth, que tem 21 pavimentos. Neste caso, o solo natural se mostrou mais compacto em relação aos outros, com valores de $\mathrm{N}_{\mathrm{SPT}}$ maiores que 10 , com $\mathrm{N}_{\mathrm{SPT}}$ médios de algumas camadas de solo natural ultrapassando o valor de 20.

Dois edifícios continuam sendo monitorados, desde início de suas construções, em setembro e outubro de 2004. Até a última medição, em junho de 2005, o Boulevard Manaíra 
tinha 18 lajes concretadas e o Edifício Stéphano, 15. As suas sapatas apresentaram recalques em torno de $6 \mathrm{~mm}$ e o maior diferencial foi de $1 \mathrm{~mm}$. A maior velocidade de recalque obtida entre os dois prédios foi de $77 \mu \mathrm{m} /$ dia.

As velocidades de recalque obtidas por meio dos recalques extrapolados para os períodos de desde o início de construção até o início do monitoramento se mostraram coerentes com as provenientes dos edifícios Boulevard Manaíra e Stéphano.

Para pesquisas posteriores relacionadas ao assunto, sugerem-se estudos de interação estrutura-solo para as situações de solo compactado e natural, assim como monitoramento de todos os pilares de edificações sobre solo melhorado. 


\section{REFERÊNCIAS BIBLIOGRÁFICAS}

ABELEV, M. Y. (1975). Compacting loess soils in the USSR. Geotechnique, vol. 25, n. 1, p. 79-82.

ABNT (1996). Projeto e execução de fundações. NBR 6122, Rio de Janeiro, 33 p.

ALONSO, U. R. (1995). Previsão e controle das fundações. 1ª Reimpressão. São Paulo, Ed. Edgard Blucher Ltda.142 p.

ALVES, A. M. L.; LOPES, F. R.; ARAGÃO, C. J. G. (2000). Proposta de Método de Fundações Superficiais em Solos Granulares Melhorados por Estacas de Compactação. In: IV SEMINÁRIO DE ENGENHARIA DE FUNDAÇÕES ESPECIAIS E GEOTECNIA. Anais São Paulo: ABEF/ABMS. v.2, p. 102-112.

AOKI, N. (1976). Considerações sobre a capacidade de carga de estacas isoladas. Curso de Extensão Universitária em Engenharia de Fundações, Universidade Gama Filho, Rio de Janeiro, 44p.

AOKI, N. (1982). Relatório Geral. In: VII CONGRESSO BRASILEIRO DE MECÂNICA DOS SOLOS E ENGENHARIA DE FUNDAÇÕES. Olinda- Recife. Anais. v.V

AOKI, N. (1997). Aspectos geotécnicos da interação estrutura - maciço de solos. In: JORNADAS SUL-AMERICANAS DE ENGENHARIA ESTRUTURAL, 28, São Carlos. v.1, p. 7-20.

AOKI, N. (2000). Reflexões sobre o comportamento de sistema isolado de fundação. In: SEFE IV, São Carlos. Anais São Paulo : ABEF/ABMS. v.1, p. 24-39.

AOKI, N.; LOPES, F.R. (1975). Estimating stress and settlements due to deep foundation. In: V CONF. PANAM. SOIL MECHANICS AND FOUNDATION ENGINEERING, Buenos Aires, 1975. Vol1. .p. 377-386 
ASAOKA, A. (1978). Observational Procedure of Settlement Prediction. In: Soils and Foundations. Japanese Society of Soil Mechanics and Foundation Engieering. v. 18, n.4, dec. - 1978., p.87 - 101 .

BELL, F. G. (1993). Engineering treatment of soils. Londres, E \& FN SPON.

BICALHO, K. V.; CASTELlO, R. R.(2004). Melhoramento de solos arenosos fofos por estacas de compactação. In: SEFE V, Anais.São Paulo: ABEF/ABMS. v.2, p. 300307.

BOUASSIDA, M.; HADHRI, T. (1995). Extreme load of soils reiforced by columns: the case of an isolated column. Soils and Foundations, vol. 35, n. 1, p. 21-35.

CINTRA, J. C. A.; AOKI, N.; ALBIERO, J. H. (2003) Tensão admissível em fundações diretas. São Carlos, Rima.

CONCIANI, W; BEZERRA, R. L; MEDEIROS, J. L. G. (1999). Características de Deformação de uma Areia de Praia Obtidas por Pressiômetro. Solos e Rochas, v.22, n.3, p. $207-214$

COPESOLO - Estacas e Fundações Ltda. (2005). Acervo.

DANZIGER, F. A. B.; DANZIGER, B. R.; CRISPEL, F. A. (2000). A medida dos recalques desde o início da construção como um controle de qualidade das fundações. In: SEFE IV, São Carlos. Anais São Paulo : ABEF/ABMS. v.1, p. 191-202.

DATYE, K. R; NAGARAJU, S. S. (1981). Design aproach and field control for stone columns, In: X ICSMFE, Stockholm, Sweden.

GOLDER, H.Q. (1971). The allowable settlement of structures. In: CUARTO CONGRESO PANAMERICANO DE MECÁNICA DE SUELOS E INGENIERÍA DE FUNDACIONES. Puerto Rico, 1971, México. 
GUSMÃO, A. D. (1994). Aspectos relevantes da interação solo-estrutura em edificações. Solos e rochas. Vol 17, No. 1. Abril 1994. p. 47-55.

GUSMÃO, A. D. (2005). Melhoramento de terrenos arenosos. In: GUSMÃO, A.D.; GUSMÃO FILHO, J.; OLIVEIRA, J. T. R.; MAIA, G. B.(eds) Geotecnia no Nordeste. Recife, Editora Universitária da UFPE, 543P.

GUSMÃO, A. D.; GUSMÃO FILHO, A. J.; MAIA, G. B. (2000). Medições de recalque de um prédio em Recife. In: SIMPÓSIO INTERAÇÃO ESTRUTURA-SOLO EM EDIFÍCIOS. São Carlos, 2000. (CD ROM). São Paulo, USP.

GUSMÃO FILHO, J. A. (1982). Prática de fundações nas capitais nordestinas. In: VII CONGRESSO BRASILEIRO DE MECÂNICA DOS SOLOS E ENGENHARIA DE FUNDAÇÕES , Anais. Recife - Olinda, v.7, p.189-206.

GUSMÃO FILHO, J. A. (1998). Fundações: do conhecimento geológico à prática da engenharia. Recife, Editora Universitária, UFPE.

HOLTZ, R. D. (1991). Stress distribution and settlement of shallow foundations. In: WINTERKORN, H. F; FANG, H. Y. (eds.). Foundation engineering handbook. New York: Ed. Van Nostrand Reinhold Co. Cap. 5

LUCENA, A. E.; BEZERRA, R. L.; GUSMÃO, A. D.(2004). Monitoramento de recalque de edifícios sobre fundações diretas desde o início da construção e avaliação da interação solo-estrutura. Solos e Rochas, v.27, n.3, p. 215-229.

MADHAV, M. R. (1985). Recent developments in the use and analysis of granular piles. In: BALASUBRAMANIAM, A. S. et al. Recent developments in ground improvement techniques. Roterdã, A. A. Balkema. Cap. 10, p. 117-129. 
MASSAD, F. (1982). Método Gráfico Para o Acompanhamento da Evolução dos Recalques com o Tempo. In : VII CONGRESSO BRASILEIRO DE MECÂNICA DOS SOLOS E ENGENHARIA DE FUNDAÇÕES. Olinda- Recife. Anais. v.II, p. 321 - 331.

MINDLIN, R. D. (1936). Force at a point in the interior of a semi-infinite solid. Physics 7:5, p. 195 apud AOKI, N.; LOPES, F.R. (1975). Estimating stress and settlements due to deep foundation. In: V CONF. PANAM. SOIL MECHANICS AND FOUNDATION ENGINEERING, Buenos Aires, 1975. Vol1. .p. 377-386.

MITCHELL, J. K. (1970). In-place treatment of foundation soils. Journal of the Soil Mechanics and Foundations Division, ASCE, vol. 96, n. SM1, p. 73-110, jan.

NOVAIS FERREIRA, H. (1976). Assentamentos Admissíveis. In: Geotecnia. SPG, n. 18, p. 53-86, nov.-dez.

NOVAIS FERREIRA, H. (1977). Assentamentos Admissíveis: parte II. In: Geotecnia. SPG, n. 19 , p. 3-20, jan. - fev.

PASSOS, P. G. O. (2001). Contribuição ao estudo do melhoramento de depósitos arenosos através de da utilização de ensaios in situ. Dissertação (Mestrado) - Universidade Federal da Paraíba, Campina Grande.apud GUSMÃO, A. D. (2005). Melhoramento de terrenos arenosos. In: GUSMÃO, A.D.; GUSMÃO FILHO, J.; OLIVEIRA, J. T. R.; MAIA, G. B.(eds) Geotecnia no Nordeste. Recife, Editora Universitária da UFPE, 543P.

REIS, J. H. C. (2000). Interação solo-estrutura de grupo de edifícios com fundações superficiais em argila mole. São Carlos, 148p. Dissertação (Mestrado) - Escola de Engenharia de São Carlos, Universidade de São Paulo. 
SCHMERTMANN, J. H. (1970) - Static cone to compute static settlement over sand Journal of the Soil Mechanics and Foundations Division, ASCE, v.96, n.SM.3, pg. 1011-1043.

SCHMERTMANN, J. H; HARTMAN, J.P.; BROWN, P. R. (1978) -Improved strain influence factor diagrams. Journal of Geotechnical Engineering Division, ASCE, v.104, n.GT8, pg. 1131-1135.

SKEMPTON, A. W.; MacDONALD, D. H. (1956). Allowable Settlement of Buildings. In: Proc. Institute of Civil Engineers, Part III. v.5, p. 727-784.

SLOCOMBE, B. C. (1993). Dynamic compaction. In: MOSELEY, M. P., ed. Ground improvement. Glasgow, Chapman \& Hall. Cap. 2, p. 20-39.

SOARES, V.B. (2000). Histórico das fundações do condomínio residencial Torino, com vinte pavimentos, em João Pessoa - PB. In: SEFE IV, São Carlos. Anais São Paulo : ABEF/ABMS. v.2, p. 451-462.

SOARES, V. B.; SOARES, W. C. (2004). Estacas de compactação (melhoramento de solos arenosos com estacas de compactação). João Pessoa, Editora paraibana. 176p.

SOARES, W.C. (2002). Estacas de compactação para melhoria de solo . 133p. Dissertação (Mestrado) - Escola de Engenharia de São Carlos, Universidade de São Paulo.

SOARES, W. C.; SOARES, V.B.; CINTRA, J.C. (2003). Sand piles for shallow foundations. In: SOIL \& ROCK AMERICA 2003, Massachusetts. (CD ROM).

STEINBRENNER, W. (1934). Tafeln sur setzsungsberechnung. Die Strasse, v. 1, p. 121 apud AOKI, N.; LOPES, F.R. (1975). Estimating stress and settlements due to deep foundation. In: V CONF. PANAM. SOIL MECHANICS AND FOUNDATION ENGINEERING, Buenos Aires, 1975. Vol1..p. 377-386. 
TEIXEIRA, A. H. (1996). Projeto e execução de fundações. In: SEFE III, Anais. São Paulo, v.1, p.33-50.

TEIXEIRA, A.H.; GODOY, N.S. (1996). Análise, projeto e execução de fundações rasas. In: HACHICH, W. et al, ed. Fundações, teoria e prática. São Paulo, PINI. Cap. 7, p.227264.

TERZAGHI,K.; PECK, R.B. (1967). Soil Mechanics in Engineering Practice. 2ed. New York: John Wiley and Sons Co. 792p.

VAN DER VEEN, C. (1953). The Bearing Capacity of a Pile. In: III INTERNATIONAL CONFERENCE ON SOIL MECHANICS AND FOUNDATION ENGINEERING. Zurich, v.2, p. $84-90$.

VARGAS, M.; LEME DE MORAES, J. T. (1989). Long term settlements of tall buildings on sand. In: Proc., XII ICSMFE, Rio de Janeiro. v.1, p. 765-768.

VELlOSO, D. A.; LOPES, F. R.(2004). Fundações: Critérios de projeto Investigação do subsolo Fundações superficiais. Nova Edição. São Paulo, Oficina de Textos. vol 1.

WALLAYS, M. (1985). Deep compaction by casing drive. In: BALASUBRAMANIAM, A. S. et al. Recent developments in ground improvement techniques. Roterdã, A. A. Balkema. Cap. 4, p. 39-52.

WEST, J. M. (1975). The role of ground improvement in foundation engineering. Geotechnique, vol. 25, n. 1, p. 71-78. 
ANEXO A 
Tabela A.1 - Carga de projeto atuante em cada sapata dos cinco edifícios

\begin{tabular}{|c|c|c|c|c|c|}
\hline \multirow{3}{*}{ Sapata } & \multicolumn{5}{|c|}{$\operatorname{Carga}(k N)$} \\
\hline & \multicolumn{5}{|c|}{ Edifício } \\
\hline & $\begin{array}{c}\text { Maison des } \\
\text { Princes }\end{array}$ & $\begin{array}{c}\text { Vale } \\
\text { Verzasca }\end{array}$ & $\begin{array}{c}\text { Maison } \\
\text { Elizabeth }\end{array}$ & $\begin{array}{l}\text { Boulevard } \\
\text { Manaíra }\end{array}$ & Stéphano \\
\hline 1 & 2038 & 1537 & 3090 & 2674 & 3200 \\
\hline 2 & 4098 & 2074 & 2540 & 4716 & 4800 \\
\hline 3 & 3152 & 5906 & 2545 & 4594 & 4200 \\
\hline 4 & 3617 & 4358 & 2956 & 2632 & 4800 \\
\hline 5 & 5087 & 4954 & 9493 & 2665 & 3200 \\
\hline 6 & 2151 & 2907 & 5406 & 4141 & 4600 \\
\hline 7 & 3076 & 6828 & 5135 & 5556 & 9000 \\
\hline 8 & 7468 & 9422 & 2836 & 4745 & 5100 \\
\hline 9 & 10458 & 5388 & 2690 & 4094 & 4600 \\
\hline 10 & 7060 & 3720 & 4274 & 1409 & 4900 \\
\hline 11 & 3467 & 10123 & 4460 & 1527 & 4120 \\
\hline 12 & 6319 & 8346 & 4514 & 1345 & 4100 \\
\hline 13 & 8032 & 3059 & 3870 & 3575 & 3800 \\
\hline 14 & 7546 & 3459 & 5224 & 2378 & 3800 \\
\hline 15 & 2612 & 3992 & 6900 & 4603 & - \\
\hline 16 & 3358 & - & 4836 & 2433 & - \\
\hline 17 & 6859 & - & 2806 & 1281 & - \\
\hline 18 & 2418 & - & 3390 & 2201 & - \\
\hline 19 & 15686 & - & 3540 & 1920 & - \\
\hline 20 & 3048 & - & 2300 & 2659 & - \\
\hline 21 & 7453 & - & - & 1800 & - \\
\hline 22 & 7030 & - & - & - & - \\
\hline 23 & 3437 & - & - & - & - \\
\hline 24 & 2287 & - & - & - & - \\
\hline 25 & 4264 & - & - & - & - \\
\hline 26 & 4131 & - & - & - & - \\
\hline 27 & 4308 & - & - & - & - \\
\hline 28 & 5109 & - & - & - & - \\
\hline 29 & 2174 & - & - & - & - \\
\hline
\end{tabular}


APÊNDICE A 
Maison des Princes - saída do programa com os recalques totais para solo natural:

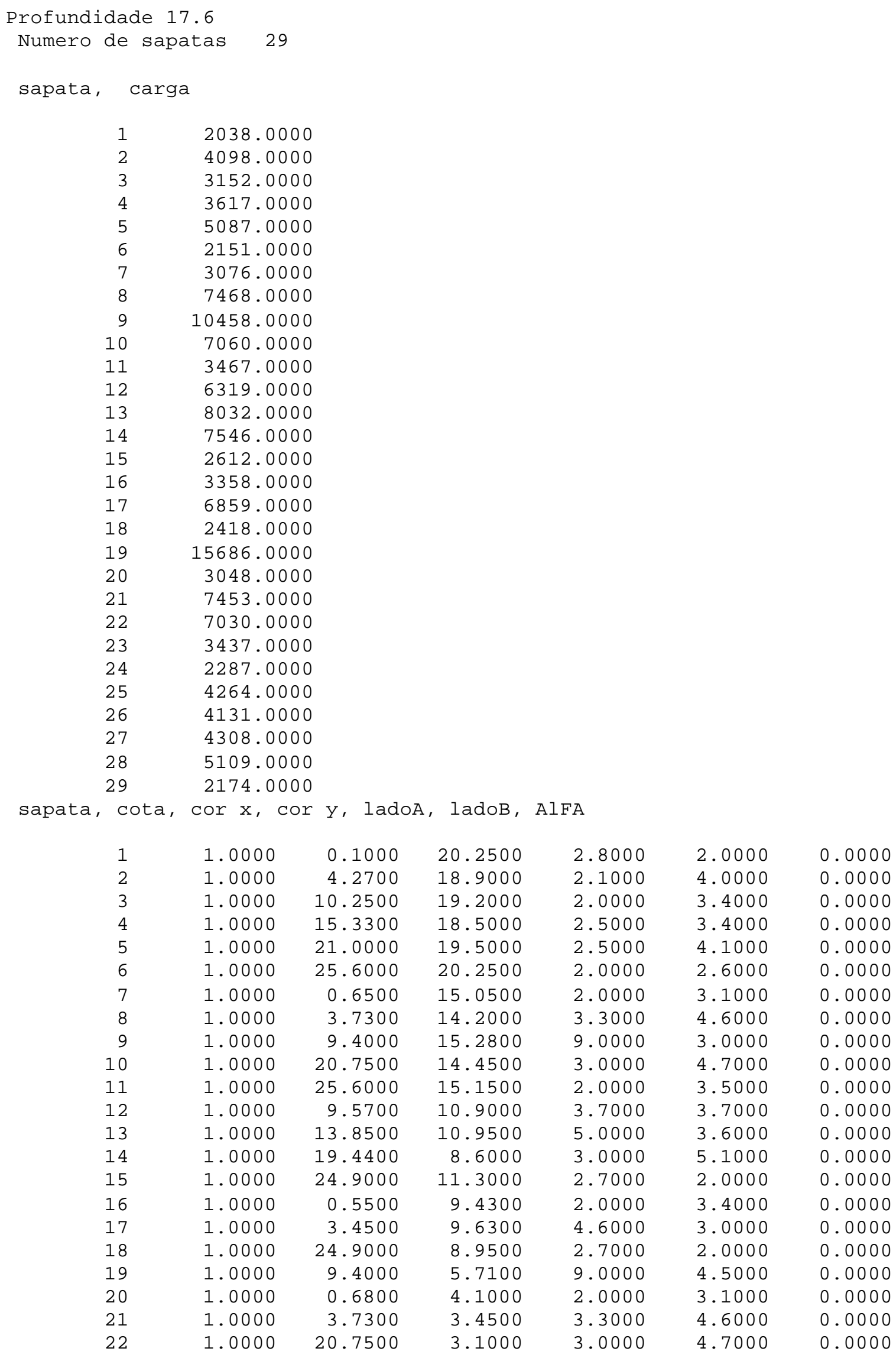




$\begin{array}{rrrrrrr}23 & 1.0000 & 25.6000 & 3.6000 & 2.0000 & 3.5000 & 0.0000 \\ 24 & 1.0000 & 0.0000 & 0.0000 & 3.0000 & 2.0000 & 0.0000 \\ 25 & 1.0000 & 4.1800 & -0.6500 & 2.3000 & 4.0000 & 0.0000 \\ 26 & 1.0000 & 9.9800 & -0.3500 & 2.5000 & 3.4000 & 0.0000 \\ 27 & 1.0000 & 15.3300 & 0.3000 & 2.5000 & 3.5000 & 0.0000 \\ 28 & 1.0000 & 21.0000 & -1.3500 & 2.5000 & 4.1000 & 0.0000 \\ 29 & 1.0000 & 25.6000 & -0.6000 & 2.0000 & 2.6000 & 0.0000\end{array}$

camada, Mod elast, poisson, profundidade

$\begin{array}{lrl}1 & 7154.0000 & 2.4000 \\ 2 & 26754.0000 & 3.8000 \\ 3 & 26325.0000 & 6.3000 \\ 4 & 11025.0000 & 7.4000 \\ 5 & 14300.0000 & 8.3000 \\ 6 & 36750.0000 & 10.0000 \\ 7 & 23716.0000 & 15.8000 \\ 8 & 28591.5000 & 17.6000 \\ \text { centro } x, \text { centroy } & \end{array}$

sapata, centro $\mathrm{x}$, centro $\mathrm{y}$

\begin{tabular}{|c|c|}
\hline & \\
\hline 1 & 1.5000 \\
\hline 2 & 5.3300 \\
\hline 3 & 11.2500 \\
\hline 4 & 16.5800 \\
\hline 5 & 22.2500 \\
\hline 6 & 26.6000 \\
\hline 7 & 1.6500 \\
\hline 8 & 5.3800 \\
\hline 9 & 13.9000 \\
\hline 10 & 22.2500 \\
\hline 11 & 26.6000 \\
\hline 12 & 11.4300 \\
\hline 13 & 16.3500 \\
\hline 14 & 20.9300 \\
\hline 15 & 26.2500 \\
\hline 16 & 1.5500 \\
\hline 17 & 5.7500 \\
\hline 18 & 26.5000 \\
\hline 19 & 13.9000 \\
\hline 20 & 1.6800 \\
\hline 21 & 5.3800 \\
\hline 22 & 22.2500 \\
\hline 23 & 26.6000 \\
\hline 24 & 1.5000 \\
\hline 25 & 5.3300 \\
\hline 26 & 11.2300 \\
\hline 27 & 16.5800 \\
\hline 28 & 22.2500 \\
\hline 29 & 26.6000 \\
\hline apata, & lque \\
\hline 1 & 0.083540 \\
\hline 2 & 0.125584 \\
\hline 3 & 0.118439 \\
\hline 4 & 0.130487 \\
\hline 5 & 0.131825 \\
\hline 6 & 0.088716 \\
\hline 7 & 0.122786 \\
\hline 8 & 0.164315 \\
\hline 9 & 0.162275 \\
\hline 10 & 0.164802 \\
\hline 11 & 0.119975 \\
\hline
\end{tabular}

21.2500
20.9000
20.9000
20.2000
21.5500
21.5500
16.6000
16.5000
16.7800
16.8000
16.9000
12.7500
12.7500
11.1500
12.3000
11.1300
11.1300
9.9500
7.9600
5.6500
5.7500
5.4500
5.3500
1.0000
1.3500
1.3500
2.0500
0.7000
0.7000 


$\begin{array}{ll}12 & 0.184837 \\ 13 & 0.190590 \\ 14 & 0.179448 \\ 15 & 0.125555 \\ 16 & 0.127365 \\ 17 & 0.169329 \\ 18 & 0.118738 \\ 19 & 0.173361 \\ 20 & 0.122543 \\ 21 & 0.162786 \\ 22 & 0.161275 \\ 23 & 0.118457 \\ 24 & 0.087677 \\ 25 & 0.125108 \\ 26 & 0.123006 \\ 27 & 0.131282 \\ 28 & 0.130759 \\ 29 & 0.088810\end{array}$

Maison des Princes - saída do programa com os recalques totais para solo compactado:

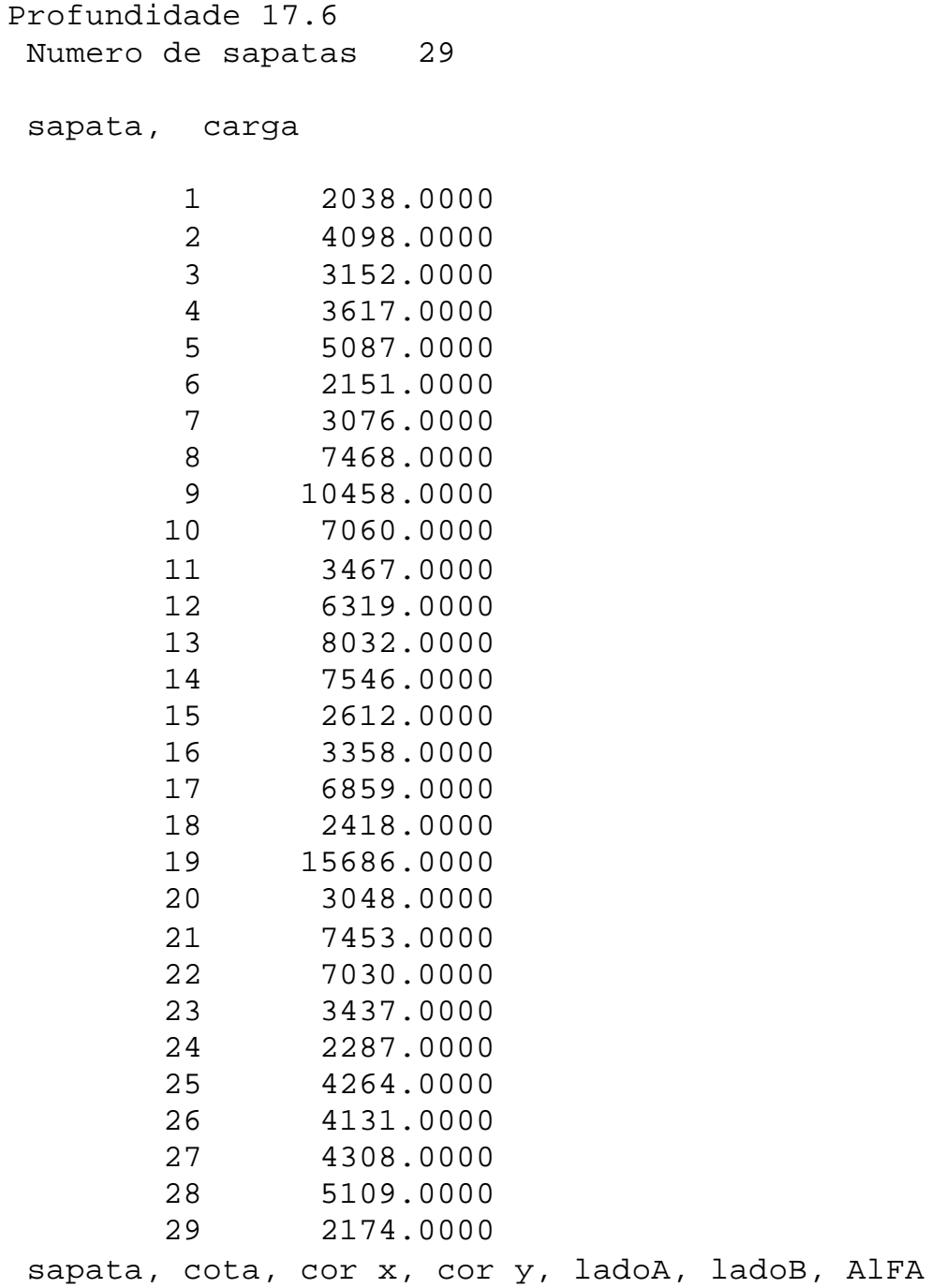




$\begin{array}{rrrrrrr}1 & 1.0000 & 0.1000 & 20.2500 & 2.8000 & 2.0000 & 0.0000 \\ 2 & 1.0000 & 4.2700 & 18.9000 & 2.1000 & 4.0000 & 0.0000 \\ 3 & 1.0000 & 10.2500 & 19.2000 & 2.0000 & 3.4000 & 0.0000 \\ 4 & 1.0000 & 15.3300 & 18.5000 & 2.5000 & 3.4000 & 0.0000 \\ 5 & 1.0000 & 21.0000 & 19.5000 & 2.5000 & 4.1000 & 0.0000 \\ 6 & 1.0000 & 25.6000 & 20.2500 & 2.0000 & 2.6000 & 0.0000 \\ 7 & 1.0000 & 0.6500 & 15.0500 & 2.0000 & 3.1000 & 0.0000 \\ 8 & 1.0000 & 3.7300 & 14.2000 & 3.3000 & 4.6000 & 0.0000 \\ 9 & 1.0000 & 9.4000 & 15.2800 & 9.0000 & 3.0000 & 0.0000 \\ 10 & 1.0000 & 20.7500 & 14.4500 & 3.0000 & 4.7000 & 0.0000 \\ 11 & 1.0000 & 25.6000 & 15.1500 & 2.0000 & 3.5000 & 0.0000 \\ 12 & 1.0000 & 9.5700 & 10.9000 & 3.7000 & 3.7000 & 0.0000 \\ 13 & 1.0000 & 13.8500 & 10.9500 & 5.0000 & 3.6000 & 0.0000 \\ 14 & 1.0000 & 19.4400 & 8.6000 & 3.0000 & 5.1000 & 0.0000 \\ 15 & 1.0000 & 24.9000 & 11.3000 & 2.7000 & 2.0000 & 0.0000 \\ 16 & 1.0000 & 0.5500 & 9.4300 & 2.0000 & 3.4000 & 0.0000 \\ 17 & 1.0000 & 3.4500 & 9.6300 & 4.6000 & 3.0000 & 0.0000 \\ 18 & 1.0000 & 24.9000 & 8.9500 & 2.7000 & 2.0000 & 0.0000 \\ 19 & 1.0000 & 9.4000 & 5.7100 & 9.0000 & 4.5000 & 0.0000 \\ 20 & 1.0000 & 0.6800 & 4.1000 & 2.0000 & 3.1000 & 0.0000 \\ 21 & 1.0000 & 3.7300 & 3.4500 & 3.3000 & 4.6000 & 0.0000 \\ 22 & 1.0000 & 20.7500 & 3.1000 & 3.0000 & 4.7000 & 0.0000 \\ 23 & 1.0000 & 25.6000 & 3.6000 & 2.0000 & 3.5000 & 0.0000 \\ 24 & 1.0000 & 0.0000 & 0.0000 & 3.0000 & 2.0000 & 0.0000 \\ 25 & 1.0000 & 4.1800 & -0.6500 & 2.3000 & 4.0000 & 0.0000 \\ 26 & 1.0000 & 9.9800 & -0.3500 & 2.5000 & 3.4000 & 0.0000 \\ 27 & 1.0000 & 15.3300 & 0.3000 & 2.5000 & 3.5000 & 0.0000 \\ 28 & 1.0000 & 21.0000 & -1.3500 & 2.5000 & 4.1000 & 0.0000 \\ 29 & 1.0000 & 25.6000 & -0.6000 & 2.0000 & 2.6000 & 0.0000\end{array}$

camada, Mod elast, poisson, profundidade

$\begin{array}{rl}52185.0000 & 2.4000 \\ 107065.0000 & 3.8000 \\ 53662.5000 & 6.3000 \\ 36529.5000 & 7.4000 \\ 26000.0000 & 8.3000 \\ 43365.0000 & 10.0000 \\ 26460.0000 & 15.8000 \\ 28591.5000 & 17.6000\end{array}$

sapata, centro $x$, centro y

$\begin{array}{rrr}1 & 1.5000 & 21.2500 \\ 2 & 5.3300 & 20.9000 \\ 3 & 11.2500 & 20.9000 \\ 4 & 16.5800 & 20.2000 \\ 5 & 22.2500 & 21.5500 \\ 6 & 26.6000 & 21.5500 \\ 7 & 1.6500 & 16.6000 \\ 8 & 5.3800 & 16.5000 \\ 9 & 13.9000 & 16.7800 \\ 10 & 22.2500 & 16.8000 \\ 11 & 26.6000 & 16.9000 \\ 12 & 11.4300 & 12.7500 \\ 13 & 16.3500 & 12.7500 \\ 14 & 20.9300 & 11.1500 \\ 15 & 26.2500 & 12.3000 \\ 16 & 1.5500 & 11.1300 \\ 17 & 5.7500 & 11.1300 \\ 18 & 26.5000 & 9.9500 \\ 19 & 13.9000 & 7.9600 \\ 20 & 1.6800 & 5.6500\end{array}$




$\begin{array}{cc}21 & 5.3800 \\ 22 & 22.2500 \\ 23 & 26.6000 \\ 24 & 1.5000 \\ 25 & 5.3300 \\ 26 & 11.2300 \\ 27 & 16.5800 \\ 28 & 22.2500 \\ 29 & 26.6000 \\ \text { sapatalque } \\ \\ 1 & 0.029248 \\ 2 & 0.043544 \\ 3 & 0.044629 \\ 4 & 0.050438 \\ 5 & 0.044972 \\ 6 & 0.030272 \\ 7 & 0.043550 \\ 8 & 0.060211 \\ 9 & 0.066955 \\ 10 & 0.061300 \\ 11 & 0.042330 \\ 12 & 0.074943 \\ 13 & 0.077763 \\ 14 & 0.070180 \\ 15 & 0.046434 \\ 16 & 0.046292 \\ 17 & 0.064768 \\ 18 & 0.044351 \\ 19 & 0.071558 \\ 20 & 0.043527 \\ 21 & 0.059334 \\ 22 & 0.059450 \\ 23 & 0.041643 \\ 24 & 0.030173 \\ 25 & 0.043363 \\ 26 & 0.043864 \\ 27 & 0.048022 \\ 28 & 0.044066 \\ 29 & 0.030005\end{array}$

Vale Verzasca - saída do programa com os recalques totais para solo natural:

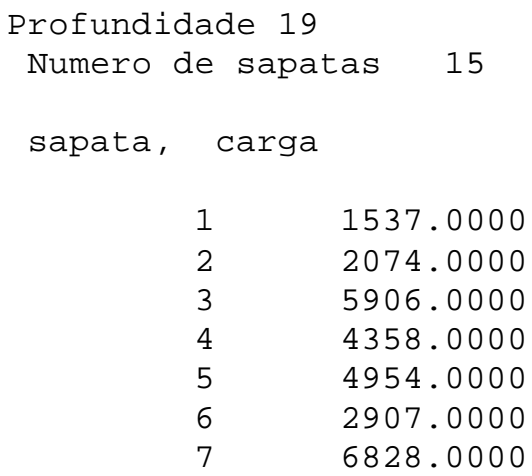




\begin{tabular}{|c|c|c|c|c|c|c|}
\hline 8 & 9422.000 & & & & & \\
\hline 9 & 5388.000 & & & & & \\
\hline 10 & 3720.0000 & & & & & \\
\hline 11 & 10123.0000 & & & & & \\
\hline 12 & 8346.0000 & & & & & \\
\hline 13 & 3059.0000 & & & & & \\
\hline 14 & 3459.0000 & & & & & \\
\hline 15 & 3992.000 & & & & & \\
\hline sapata, c & $\operatorname{cor} x, \operatorname{col}$ & $=y, l a d o A$, & ladoB, & $\mathrm{AlFA}$ & & \\
\hline 1 & 1.0000 & 3.0100 & 25.4500 & 2.7000 & 1.9000 & 0.0000 \\
\hline 2 & 1.0000 & 2.5450 & 23.2550 & 3.0000 & 1.9000 & 0.0000 \\
\hline 3 & 1.0000 & 7.4200 & 22.7550 & 4.1000 & 3.0000 & 0.0000 \\
\hline 4 & 1.0000 & 0.1500 & 19.1250 & 4.5000 & 2.7000 & 0.0000 \\
\hline 5 & 1.0000 & 7.1450 & 18.8750 & 4.0000 & 3.2000 & 0.0000 \\
\hline 6 & 1.0000 & 11.1900 & 18.6250 & 2.6000 & 3.6000 & 0.0000 \\
\hline 7 & 1.0000 & 0.0000 & 13.7000 & 4.8000 & 3.2000 & 0.0000 \\
\hline 8 & 1.0000 & 6.3400 & 14.0500 & 8.0000 & 2.5000 & 0.0000 \\
\hline 9 & 1.0000 & 6.1400 & 11.4000 & 4.3000 & 2.6000 & 0.0000 \\
\hline 10 & 1.0000 & 0.5500 & 5.6500 & 2.8000 & 3.6000 & 0.0000 \\
\hline 11 & 1.0000 & 3.4030 & 4.0320 & 4.1000 & 5.2000 & 0.0000 \\
\hline 12 & 1.0000 & 9.2400 & 5.6500 & 4.7000 & 3.5500 & 0.0000 \\
\hline 13 & 1.0000 & 0.6700 & 0.2750 & 3.4000 & 3.4000 & 0.0000 \\
\hline 14 & 1.0000 & 4.1450 & 0.0000 & 2.1000 & 4.0000 & 0.0000 \\
\hline 15 & 1.0000 & 9.7400 & 0.6250 & 3.7000 & 2.7000 & 0.0000 \\
\hline
\end{tabular}

camada, Mod elast, poisson, profundidade

\begin{tabular}{|c|c|c|}
\hline \multicolumn{3}{|c|}{13500.0000} \\
\hline 2 & 17 & 50.0000 \\
\hline 3 & 20 & 105.0000 \\
\hline 4 & 36 & 750.0000 \\
\hline 5 & 18 & 520.0000 \\
\hline 6 & 20 & 325.0000 \\
\hline 7 & & $\$ 20.0000$ \\
\hline sapata, cer & $\mathrm{x}$, centro & $\mathrm{y}$ \\
\hline 1 & 4.3600 & 26.4000 \\
\hline 2 & 4.0450 & 24.2000 \\
\hline 3 & 9.4700 & 24.2500 \\
\hline 4 & 2.4000 & 20.4700 \\
\hline 5 & 9.1450 & 20.4700 \\
\hline 6 & 12.4900 & 20.4200 \\
\hline 7 & 2.4000 & 15.3000 \\
\hline 8 & 10.3300 & 15.3000 \\
\hline 9 & 8.2900 & 12.7000 \\
\hline 10 & 1.9450 & 7.4500 \\
\hline 11 & 5.4450 & 6.6230 \\
\hline 12 & 11.5900 & 7.4250 \\
\hline 13 & 2.3700 & 1.9750 \\
\hline 14 & 5.1950 & 2.0000 \\
\hline 15 & 11.5900 & 1.9700 \\
\hline
\end{tabular}

$$
\begin{aligned}
& 1.5000 \\
& 3.4000 \\
& 4.8000 \\
& 9.0000 \\
& 14.7000 \\
& 16.6000 \\
& 19.0000
\end{aligned}
$$

sapata, recalque

$\begin{array}{ll}1 & 0.075935 \\ 2 & 0.094904 \\ 3 & 0.122913 \\ 4 & 0.108551 \\ 5 & 0.136250 \\ 6 & 0.110222 \\ 7 & 0.134765 \\ 8 & 0.156034\end{array}$




$\begin{array}{rr}9 & 0.164440 \\ 10 & 0.125722 \\ 11 & 0.164289 \\ 12 & 0.146217 \\ 13 & 0.096096 \\ 14 & 0.118551 \\ 15 & 0.099455\end{array}$

Vale Verzasca - saída do programa com os recalques totais para solo compactado:

\begin{tabular}{|c|c|c|c|c|c|c|c|}
\hline \multicolumn{8}{|c|}{ Profundidade 19} \\
\hline Numero $d$ & le sapa & tas & & & & & \\
\hline sapata, & carga & & & & & & \\
\hline & 1 & 1537.0000 & & & & & \\
\hline & 2 & 2074.0000 & & & & & \\
\hline & 3 & 5906.0000 & & & & & \\
\hline & 4 & 4358.0000 & & & & & \\
\hline & 5 & 4954.0000 & & & & & \\
\hline & 6 & 2907.0000 & & & & & \\
\hline & 7 & 6828.0000 & & & & & \\
\hline & 8 & 9422.0000 & & & & & \\
\hline & 9 & 5388.0000 & & & & & \\
\hline & 0 & 3720.0000 & & & & & \\
\hline & 1 & 10123.0000 & & & & & \\
\hline & 2 & 8346.0000 & & & & & \\
\hline & 3 & 3059.0000 & & & & & \\
\hline & 4 & 3459.0000 & & & & & \\
\hline & 5 & 3992.0000 & & & & & \\
\hline sapata, & cota, & $\operatorname{cor} x, \operatorname{cor}$ & $y$, ladoA, & ladoB, & $A \perp F A$ & & \\
\hline & 1 & 1.0000 & 3.0100 & 25.4500 & 2.7000 & 1.9000 & 0.0000 \\
\hline & 2 & 1.0000 & 2.5450 & 23.2550 & 3.0000 & 1.9000 & 0.0000 \\
\hline & 3 & 1.0000 & 7.4200 & 22.7550 & 4.1000 & 3.0000 & 0.0000 \\
\hline & 4 & 1.0000 & 0.1500 & 19.1250 & 4.5000 & 2.7000 & 0.0000 \\
\hline & 5 & 1.0000 & 7.1450 & 18.8750 & 4.0000 & 3.2000 & 0.0000 \\
\hline & 6 & 1.0000 & 11.1900 & 18.6250 & 2.6000 & 3.6000 & 0.0000 \\
\hline & 7 & 1.0000 & 0.0000 & 13.7000 & 4.8000 & 3.2000 & 0.0000 \\
\hline & 8 & 1.0000 & 6.3400 & 14.0500 & 8.0000 & 2.5000 & 0.0000 \\
\hline & 9 & 1.0000 & 6.1400 & 11.4000 & 4.3000 & 2.6000 & 0.0000 \\
\hline & 0 & 1.0000 & 0.5500 & 5.6500 & 2.8000 & 3.6000 & 0.0000 \\
\hline & 1 & 1.0000 & 3.4030 & 4.0320 & 4.1000 & 5.2000 & 0.0000 \\
\hline & 2 & 1.0000 & 9.2400 & 5.6500 & 4.7000 & 3.5500 & 0.0000 \\
\hline & 3 & 1.0000 & 0.6700 & 0.2750 & 3.4000 & 3.4000 & 0.0000 \\
\hline & 4 & 1.0000 & 4.1450 & 0.0000 & 2.1000 & 4.0000 & 0.0000 \\
\hline & 5 & 1.0000 & 9.7400 & 0.6250 & 3.7000 & 2.7000 & 0.0000 \\
\hline
\end{tabular}

camada, Mod elast, poisson, profundidade

$\begin{array}{ll}29700.0000 & 1.5000 \\ 56350.0000 & 3.4000 \\ 94710.0000 & 4.8000 \\ 46305.0000 & 9.0000 \\ 18130.0000 & 14.7000 \\ 33810.0000 & 16.6000\end{array}$




\begin{tabular}{crr}
7 & \multicolumn{3}{c}{5720.0000} \\
sapata, centro & $x$, centro $y$ \\
1 & 4.3600 & 26.4000 \\
2 & 4.0450 & 24.2000 \\
3 & 9.4700 & 24.2500 \\
4 & 2.4000 & 20.4700 \\
5 & 9.1450 & 20.4700 \\
6 & 12.4900 & 20.4200 \\
7 & 2.4000 & 15.3000 \\
8 & 10.3300 & 15.3000 \\
9 & 8.2900 & 12.7000 \\
10 & 1.9450 & 7.4500 \\
11 & 5.4450 & 6.6230 \\
12 & 11.5900 & 7.4250 \\
13 & 2.3700 & 1.9750 \\
14 & 5.1950 & 2.0000 \\
15 & 11.5900 & 1.9700
\end{tabular}

$0.4000 \quad 19.0000$

$\begin{array}{rl}1 & 0.047531 \\ 2 & 0.059443 \\ 3 & 0.071521 \\ 4 & 0.068331 \\ 5 & 0.085141 \\ 6 & 0.069895 \\ 7 & 0.083214 \\ 8 & 0.096681 \\ 9 & 0.103080 \\ 10 & 0.078604 \\ 11 & 0.098979 \\ 12 & 0.087942 \\ 13 & 0.060045 \\ 14 & 0.072184 \\ 15 & 0.060624\end{array}$

Maison Elizabeth - saída do programa com os recalques totais para solo natural:

\begin{tabular}{|c|c|c|}
\hline \multicolumn{3}{|c|}{ Profundidade 15.7} \\
\hline sapata, & carga & \\
\hline 1 & 309 & .0000 \\
\hline 2 & 254 & .0000 \\
\hline 3 & 254 & 5.0000 \\
\hline 4 & 295 & 5.0000 \\
\hline 5 & 949 & 3.0000 \\
\hline 6 & 540 & 5.0000 \\
\hline 7 & 513 & 5.0000 \\
\hline 8 & 283 & 5.0000 \\
\hline 9 & 269 & .0000 \\
\hline 10 & 427 & $\$ .0000$ \\
\hline 11 & 446 & .0000 \\
\hline 12 & 451 & 4.0000 \\
\hline
\end{tabular}




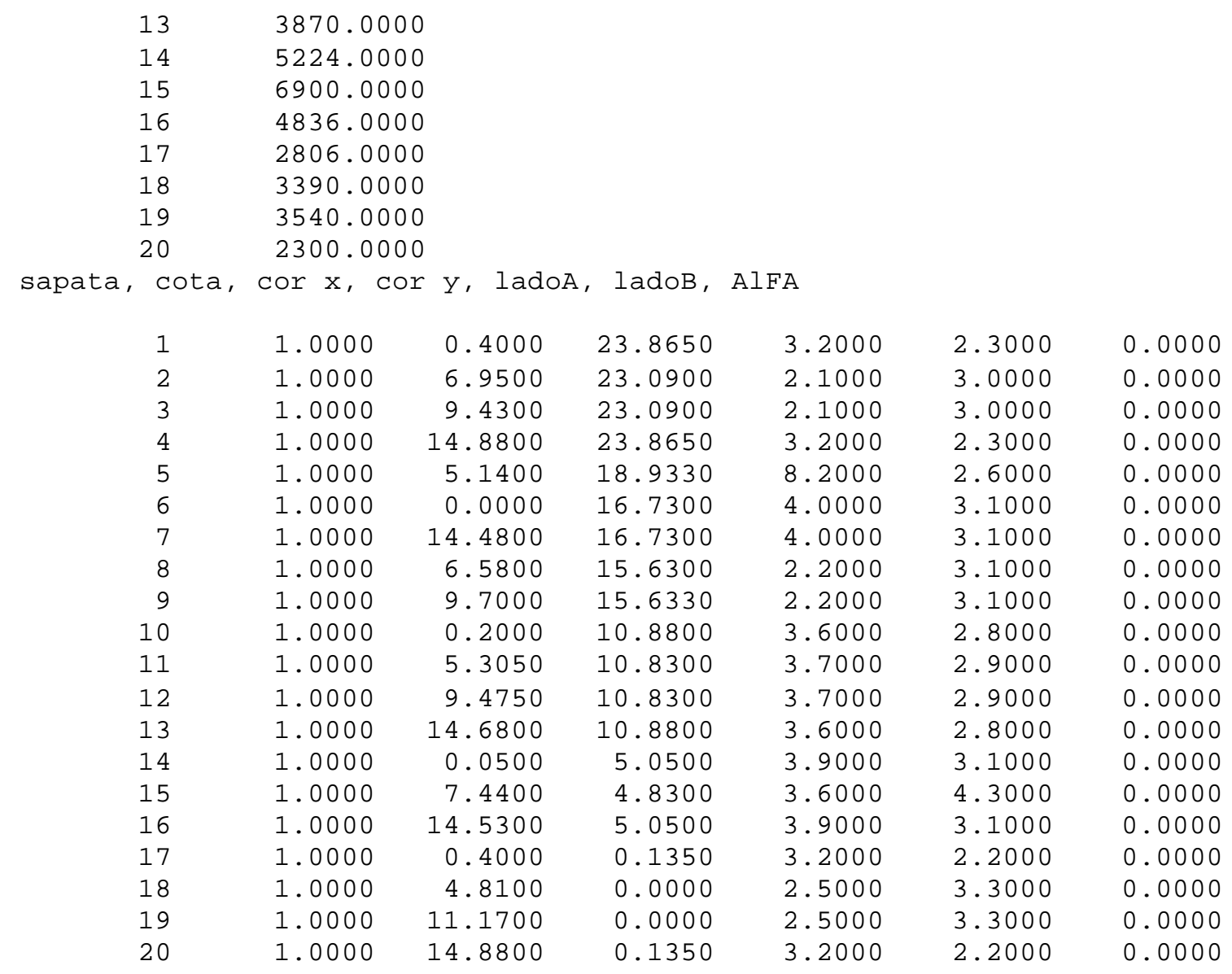

camada, Mod elast, poisson, profundidade

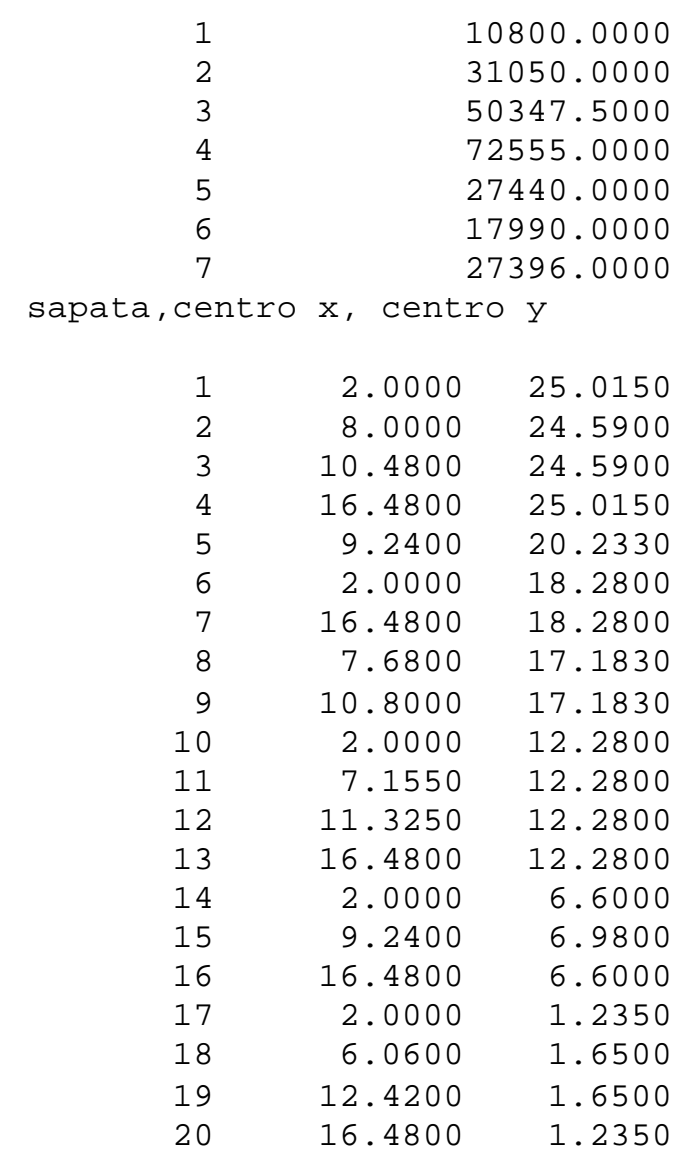


sapata, recalque

$$
\begin{aligned}
& 0.040002 \\
& 0.052407 \\
& 0.052321 \\
& 0.038618 \\
& 0.074475 \\
& 0.057465 \\
& 0.055169 \\
& 0.071352 \\
& 0.070041 \\
& 0.056019 \\
& 0.069403 \\
& 0.069143 \\
& 0.052441 \\
& 0.054409 \\
& 0.067793 \\
& 0.051069 \\
& 0.040146 \\
& 0.047979 \\
& 0.048206 \\
& 0.035435
\end{aligned}
$$

\section{Maison Elizabeth - saída do programa com os recalques totais para solo compactado:}

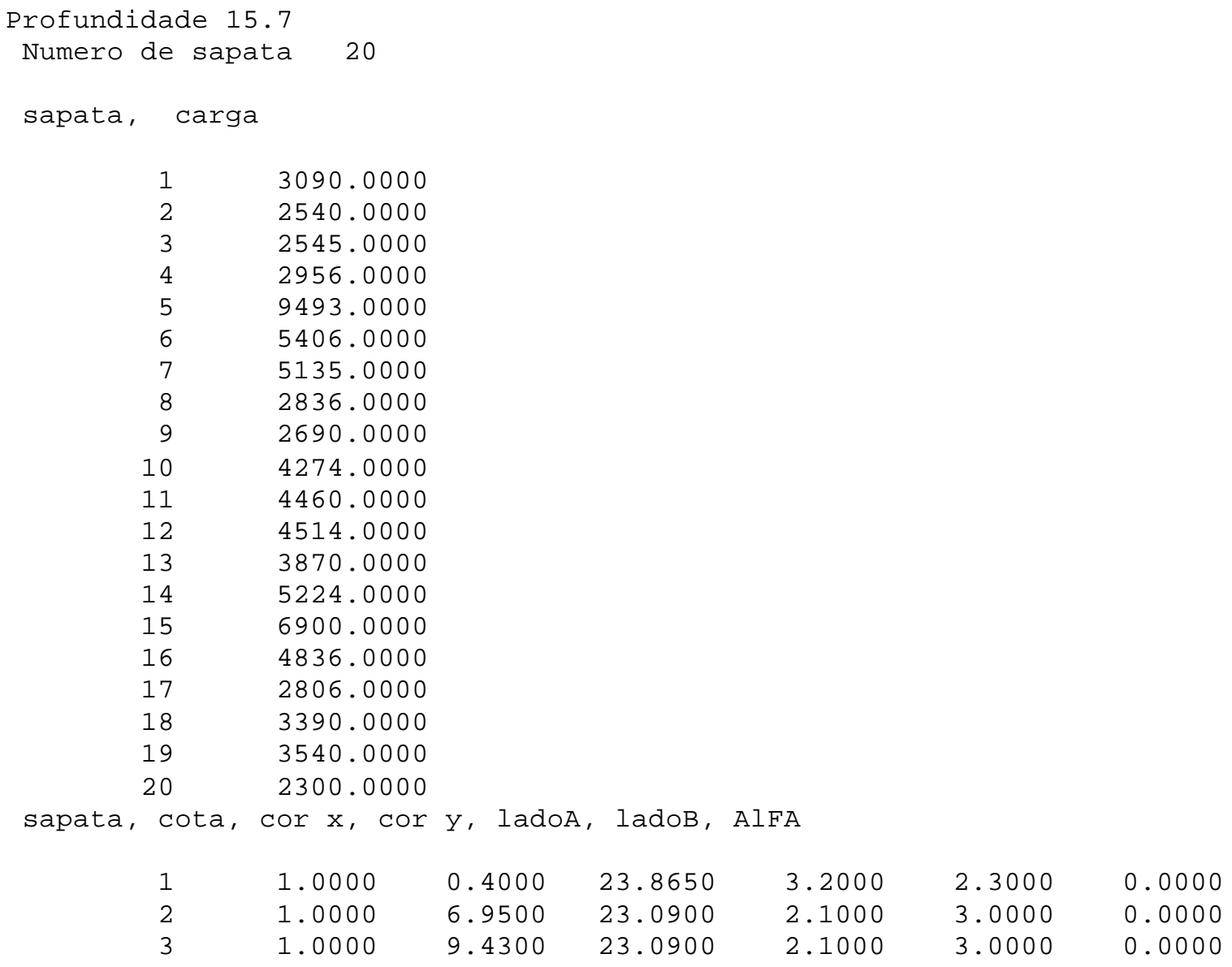

$\begin{array}{lllllll}1 & 1.0000 & 0.4000 & 23.8650 & 3.2000 & 2.3000 & 0.0000 \\ 2 & 1.0000 & 6.9500 & 23.0900 & 2.1000 & 3.0000 & 0.0000 \\ 3 & 1.0000 & 9.4300 & 23.0900 & 2.1000 & 3.0000 & 0.0000\end{array}$




$\begin{array}{rrrrrrr}4 & 1.0000 & 14.8800 & 23.8650 & 3.2000 & 2.3000 & 0.0000 \\ 5 & 1.0000 & 5.1400 & 18.9330 & 8.2000 & 2.6000 & 0.0000 \\ 6 & 1.0000 & 0.0000 & 16.7300 & 4.0000 & 3.1000 & 0.0000 \\ 7 & 1.0000 & 14.4800 & 16.7300 & 4.0000 & 3.1000 & 0.0000 \\ 8 & 1.0000 & 6.5800 & 15.6300 & 2.2000 & 3.1000 & 0.0000 \\ 9 & 1.0000 & 9.7000 & 15.6330 & 2.2000 & 3.1000 & 0.0000 \\ 10 & 1.0000 & 0.2000 & 10.8800 & 3.6000 & 2.8000 & 0.0000 \\ 11 & 1.0000 & 5.3050 & 10.8300 & 3.7000 & 2.9000 & 0.0000 \\ 12 & 1.0000 & 9.4750 & 10.8300 & 3.7000 & 2.9000 & 0.0000 \\ 13 & 1.0000 & 14.6800 & 10.8800 & 3.6000 & 2.8000 & 0.0000 \\ 14 & 1.0000 & 0.0500 & 5.0500 & 3.9000 & 3.1000 & 0.0000 \\ 15 & 1.0000 & 7.4400 & 4.8300 & 3.6000 & 4.3000 & 0.0000 \\ 16 & 1.0000 & 14.5300 & 5.0500 & 3.9000 & 3.1000 & 0.0000 \\ 17 & 1.0000 & 0.4000 & 0.1350 & 3.2000 & 2.2000 & 0.0000 \\ 18 & 1.0000 & 4.8100 & 0.0000 & 2.5000 & 3.3000 & 0.0000 \\ 19 & 1.0000 & 11.1700 & 0.0000 & 2.5000 & 3.3000 & 0.0000 \\ 20 & 1.0000 & 14.8800 & 0.1350 & 3.2000 & 2.2000 & 0.0000\end{array}$

camada, Mod elast, poisson, profundidade

\begin{tabular}{|c|c|}
\hline \\
\hline & 324 \\
\hline 2 & 847 \\
\hline 3 & 1109 \\
\hline 4 & \\
\hline 5 & \\
\hline 6 & \\
\hline 7 & \\
\hline \multicolumn{2}{|c|}{ sapata, centro $x$, centro } \\
\hline 1 & 2.0000 \\
\hline 2 & 8.0000 \\
\hline 3 & 10.4800 \\
\hline 4 & 16.4800 \\
\hline 5 & 9.2400 \\
\hline 6 & 2.0000 \\
\hline 7 & 16.4800 \\
\hline 8 & 7.6800 \\
\hline 9 & 10.8000 \\
\hline 10 & 2.0000 \\
\hline 11 & 7.1550 \\
\hline 12 & 11.3250 \\
\hline 13 & 16.4800 \\
\hline 14 & 2.0000 \\
\hline 15 & 9.2400 \\
\hline 16 & 16.4800 \\
\hline 17 & 2.0000 \\
\hline 18 & 6.0600 \\
\hline 19 & 12.4200 \\
\hline 20 & 16.4800 \\
\hline \multicolumn{2}{|c|}{ sapata, recalque } \\
\hline 1 & 0.026317 \\
\hline 2 & 0.037618 \\
\hline 3 & 0.037517 \\
\hline 4 & 0.025522 \\
\hline 5 & 0.054741 \\
\hline 6 & 0.040407 \\
\hline 7 & 0.038957 \\
\hline 8 & 0.054357 \\
\hline 9 & 0.053684 \\
\hline 10 & 0.040193 \\
\hline 11 & 0.054398 \\
\hline
\end{tabular}

$$
\begin{aligned}
& 0.5000 \\
& 3.7000 \\
& 4.8000 \\
& 7.0000 \\
& 9.5000 \\
& 13.0000 \\
& 15.7000
\end{aligned}
$$

$$
2.3000
$$$$
.0000
$$$$
0
$$

0

0




$\begin{array}{ll}12 & 0.052010 \\ 13 & 0.038063 \\ 14 & 0.037701 \\ 15 & 0.049064 \\ 16 & 0.035607 \\ 17 & 0.026776 \\ 18 & 0.033339 \\ 19 & 0.033067 \\ 20 & 0.024335\end{array}$

\section{Boulevard Manaíra - saída do programa com os recalques totais para solo natural:}

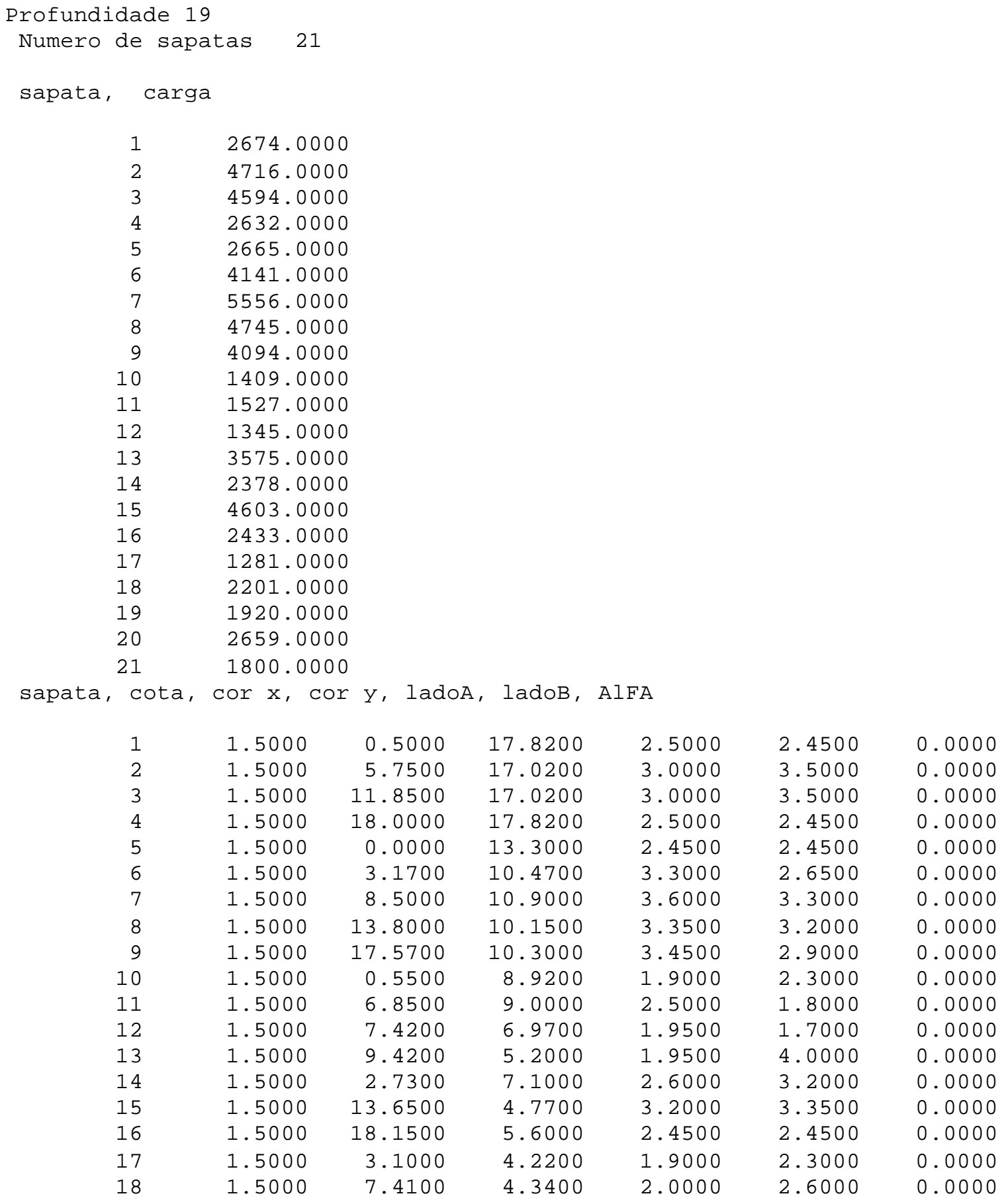

2. 0000

2.3000

0.0000 


$\begin{array}{rrrrrrr}19 & 1.5000 & 7.7700 & 0.5200 & 2.4000 & 2.1500 & 0.0000 \\ 20 & 1.5000 & 12.9500 & 0.0000 & 2.3000 & 2.6000 & 0.0000 \\ 21 & 1.5000 & 18.0500 & 0.2200 & 2.1000 & 2.3000 & 0.0000\end{array}$

camada, Mod elast, poisson, profundidade

$\begin{array}{lrl}1 & 27000.0000 & 1.0000 \\ 2 & 26040.0000 & 2.5000 \\ 3 & 50085.0000 & 4.1000 \\ 4 & 56840.0000 & 8.3000 \\ 5 & 6300.0000 & 10.1000 \\ 6 & 18645.0000 & 11.2000 \\ 7 & 20090.0000 & 15.0000 \\ 8 & 26460.0000 & 19.0000\end{array}$

sapata, centro $x$, centro $y$

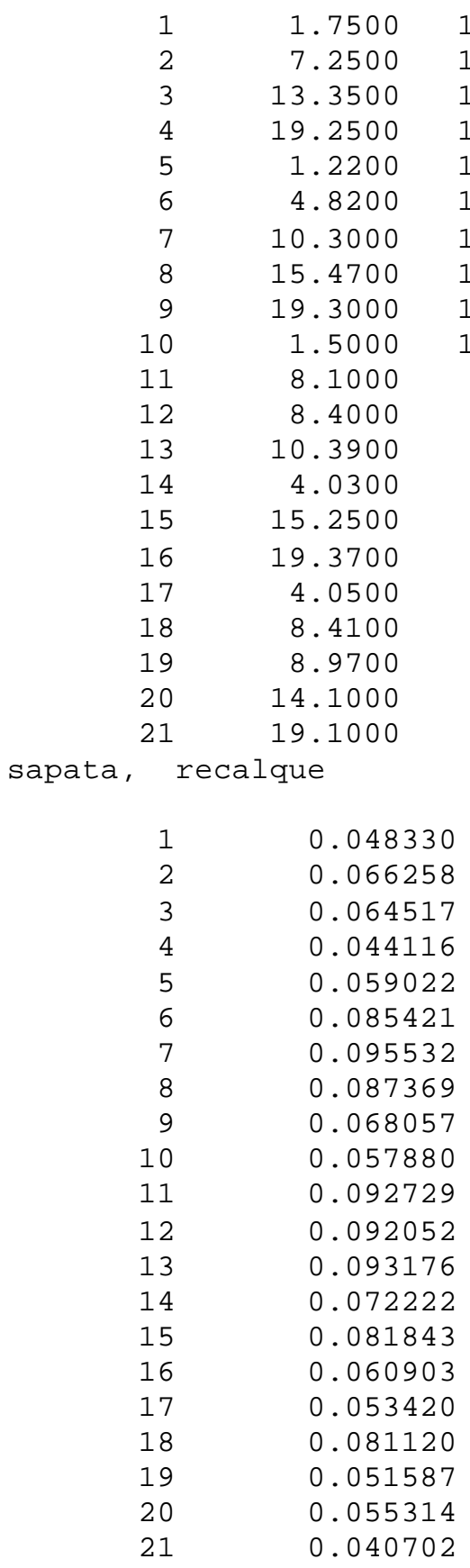

19.0500

18.7700

18.7700

19.0500

14.3500

11.8000

12.5500

11.7500

11.7500

10.0700

9.9000

7.8200

7.2000

8.7000

6.4500

6.8200

5.3700

5.6400

1.6000

1.3000

1. 3700 
Boulevard Manaíra - saída do programa com os recalques totais para solo compactado:

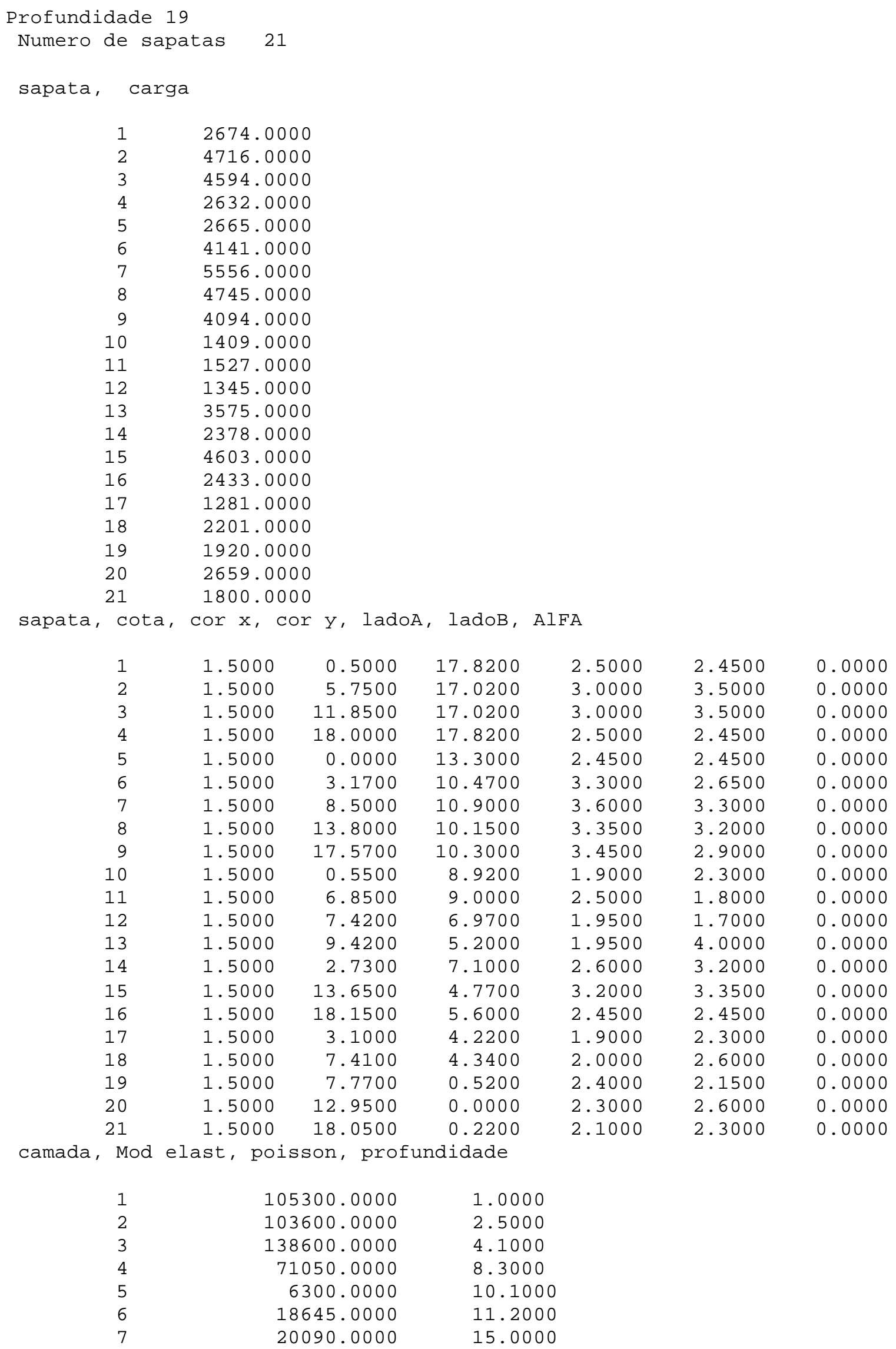


8

sapata, centro $x$, centro $y$

26460.0000

1.7500

7.2500

13.3500

19.2500

1.2200

4.8200

10.3000

15.4700

19.3000

1.5000

8.1000

8.4000

10.3900

4.0300

15.2500

19.3700

4.0500

8.4100

8.9700

14.1000

19.1000

sapata, recalque
0.037629
0.052904
0.051562
0.033965
0.047551
0.070117
0.079588
0.072412
0.055009
0.048614
0.079548
0.077201
0.077602
0.061303
0.067843
0.050066
0.045866
0.067391
0.042650
0.044388
0.032436

19.0500

18.7700

18.7700

19.0500

14.3500

11.8000

12.5500

11.7500

11.7500

10.0700

9.9000

7.8200

7.2000

8.7000

6.4500

6.8200

5.3700

5.6400

1.3000

1. 3700
1.6000 
Stéphano - saída do programa com os recalques totais para solo natural:

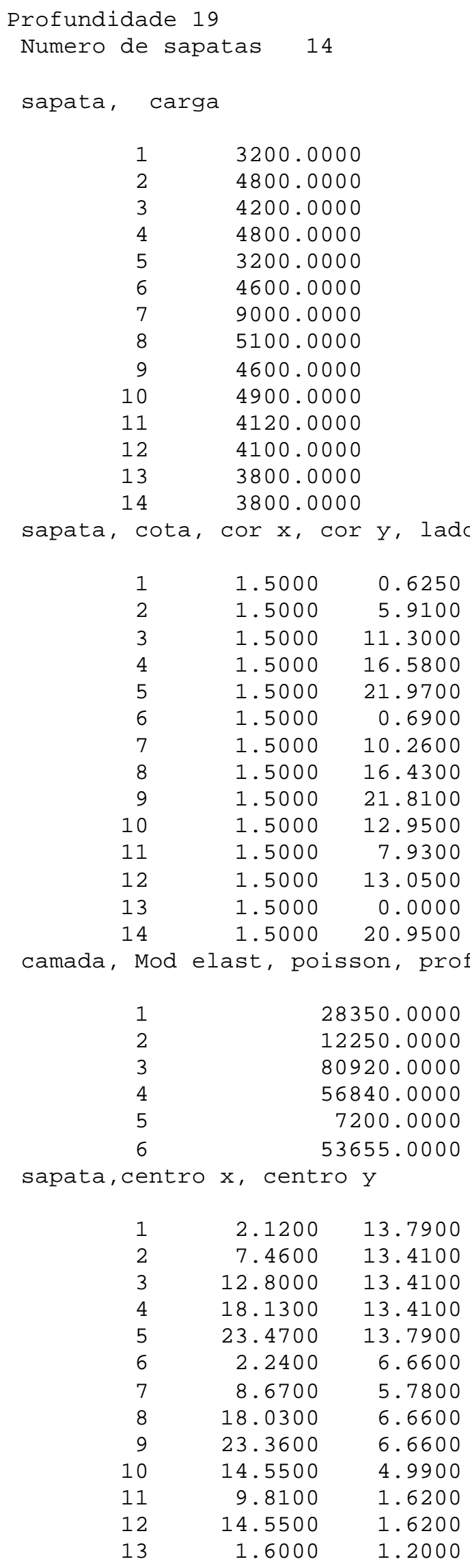




\begin{tabular}{cl} 
sapata, & \multicolumn{2}{l}{22.5500} \\
1 & 0.052545 \\
2 & 0.070034 \\
3 & 0.067398 \\
4 & 0.069468 \\
5 & 0.052280 \\
6 & 0.067929 \\
7 & 0.095278 \\
8 & 0.090942 \\
9 & 0.067067 \\
10 & 0.101073 \\
11 & 0.080015 \\
12 & 0.082962 \\
13 & 0.056742 \\
14 & 0.058820
\end{tabular}

\section{Stéphano - saída do programa com os recalques totais para solo compactado:}

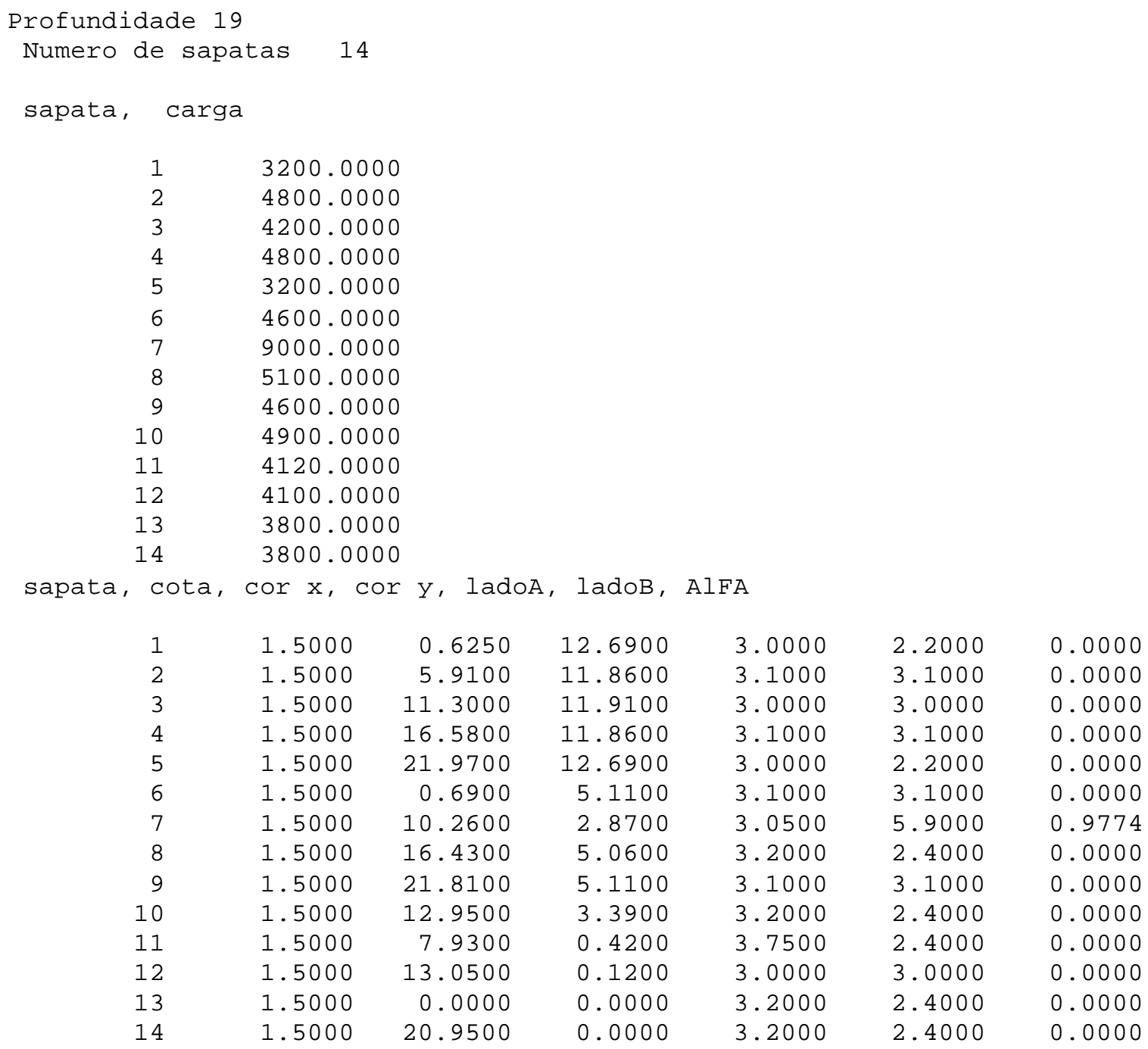


sapata, Mod elast, poisson, profundidade

\begin{tabular}{crr}
1 & & 81000.0000 \\
2 & 36260.0000 \\
3 & 96320.0000 \\
4 & 56840.0000 \\
5 & \multicolumn{2}{r}{5200.0000} \\
6 & 3655.0000 \\
sapata, centro $\mathrm{x}$, centro & \\
& & \\
1 & 2.1200 & 13.7900 \\
2 & 7.4600 & 13.4100 \\
3 & 12.8000 & 13.4100 \\
4 & 18.1300 & 13.4100 \\
5 & 23.4700 & 13.7900 \\
6 & 2.2400 & 6.6600 \\
7 & 8.6700 & 5.7800 \\
8 & 18.0300 & 6.6600 \\
9 & 23.3600 & 6.6600 \\
10 & 14.5500 & 4.9900 \\
11 & 9.8100 & 1.6200 \\
12 & 14.5500 & 1.6200 \\
13 & 1.6000 & 1.2000 \\
14 & 22.5500 & 1.2000 \\
recalque &
\end{tabular}

$\begin{array}{rl}1 & 0.032977 \\ 2 & 0.046341 \\ 3 & 0.045731 \\ 4 & 0.045796 \\ 5 & 0.032713 \\ 6 & 0.045172 \\ 7 & 0.067156 \\ 8 & 0.062150 \\ 9 & 0.044312 \\ 10 & 0.070765 \\ 11 & 0.056758 \\ 12 & 0.058713 \\ 13 & 0.035559 \\ 14 & 0.037607\end{array}$

